\title{
DISCLAIM
}

This report was prepared as an account of work sponsored by an agency of the United States Government. Neither the United States Government nor any agency thereof. nor any of their employees, makes any warranty, express or implied, or assumes any legal liability or responsibility for the accuracy, completeness, or usefulness of any information, apparatus, product, or process disclosed, or represents that iss use would not infringe privacely owned rights. Reference herein to any specific commercial product, process or service by trade name, trademark, manufacturer, or otherwise does not necessarily constitute or imply its endorsement, recommendation, or favoring by the United States Government or any agency thereof. The views and opinions of authors ex. pressed herein do not necessarily state or reflect those of the United States Government or any agency thereof.

This report has been reproduced directly from the best available copy.

Available to DOE and DOE contractors from the Office of Scientific and Technical Information, P.O. Box 62, Oak Ridge, TN 37831; prices available from (615)576-8401.

A vailable to the public from the National Technical Information Service, U. S. Department of Commerce, 5285 Port Royal Rd., Springfield, VA 22161. 


\section{DEVELOPMENT OF THE LICADO \\ COAL CLEANING PROCESS}

\section{FINAL REPORT}

FOR

OCTOBER 1, 1987 TO APRIL 2, 1990

CUSTOMER ORDER MO.

DE-AC22-87PC79873

\section{WESTINGHOUSE ELECTRIC CORPORATION ADVANCED ENERGY SYSTEMS \\ P.0. BOX 10864 \\ PITTSBURGH, PA 15236-0864}

JULY 31, 1990 
This report was prepared as an account of work sponsored by the United States Government. Neither the United States Government nor the United States Department of Energy, nor any of their employees, makes any warranty, express or implied, or assumes any legal liability or responsibility for the accuracy, completeness, or usefulness of any information, apparatus, product, or process disclosed, or represents that its use would not infringe privately owned rights. Reference herein to any specific commercial product, process, or service by trade name, trademark, manufacturer, or otherwise, does not necessarily constitute or imply its endorsement, recommendation, or favoring by the United States Government or any agency thereof. The views and opinions of authors expressed herein do not necessarily state or reflect those of the United States Government or any agency thereof.

Patents cleared by Office of Patent Counsel, Chicago Operations Office on June 7, 1990. 
Development of the liquid carbon dioxide process for the cleaning of coal was performed in batch, variable volume (semi-continuous), and continuous tests. Continuous operation at feed rates up to $4.5 \mathrm{~kg} / \mathrm{hr}(10-1 \mathrm{~b} / \mathrm{hr})$ was achieved with the Continuous system. Coals tested included Upper Freeport, Pittsburgh, Illinois No. 6, and Middle Kittanning seams. Results showed that the ash and pyrite rejections agreed closely with the washability data for each coal at the particle size tested (-200 mesh). A 0.91 metric ton (1-ton) per hour Proof-of-Concept Plant was conceptually designed. A 181 metric ton (200 ton) per hour and a 45 metric ton (50 ton) per hour plant were sized sufficiently to estimate costs for economic analyses. The processing costs for the 181 metric ton (200 ton) per hour and 45 metric ton (50 ton) per hour were estimated to be $\$ 18.96$ per metric ton ( $\$ 17.20$ per ton) and $\$ 11.47$ per metric ton ( $\$ 10.40$ per ton), respectively for these size plants. The costs for the 45 metric ton per hour plant are lower because it is assumed to be a fines recovery plant which does not require a grinding circuit or complex waste handling system. 


\section{TABLE OF CONTENTS}

Section

Page No.

1.0

Introduction

$1-1$

2.0

Objectives

$2-1$

3.0

Experimental Program for Batch Tests

$3-1$

3.1

Fixed Volume Batch Tests.

$3-8$

3.1 .1

Equipment

$3-8$

3.1 .2

Procedure

$3-11$

3.1 .3

Results and Discussion.

$3-12$

3.2

Variable Volume Batch Tests

$3-23$

3.2 .1

Equipment

$3-24$

3.2 .2

Procedure

$3-24$

3.2.3 Results and Discussion.

$3-27$

3.2.4 Summary of Variable Volume Tests............. 3-47

3.2.5 Comparison with Washability Data.............. 3-48

3.3

Agglomeration/Screening Tests

$3-52$

3. 3.1

Equipment

$3 \cdot 52$

3.3 .2

Procedure

3-56

3.3.3 Results and Discussion

$3-56$

4.0

Continuous Research Unit.

4-1

4.1

Equipment

4-1

4.1 .1

Clean Coal/Refuse Separator.

4-1

4.1 .2

Premixing Tank.

4-5

4.1 .3

Slurry Preparation Unit...

4-5

4.1 .4

Clean Coal/Liquid $\mathrm{CO}_{2}$ Separator

4- 5

4.1 .5

Refuse/Water Separator

4-7 
TABLE OF CONTENTS (Cont'd.)

Section

Page No.

4.2

Procedure.

$4-7$

4.2.1 Continuous Operation Control Schemes............. 4-10

4.3 Results and Discussion..................... 4-15

$5.0 \quad$ Continuous Unit............................ $5-1$

$5.1 \quad$ Equipment.............................. $5-1$

6.0 Simulation Model.......................... $6-1$

6.1 Description of Mode1....................... 6-1

6.2 Results............................... $6-6$

6.2.1 Plant Studies............................. $6-6$

6.2 .2 Separator/Mixer Studies..................... $6-6$

6.2.3 Continuous Research Unit Study................. $6-11$

7.0 Conceptual Plant Design...................... 7-1

7.1 Proof-of-Concept Plant..................... 7-1

7.1.1 Requirements of the POC Plant................ 7-2

7.1.2 Process Consideration...................... 7-5

7.1.3 Plant Subsystems........................ 7-9

7.1.4 Instrumentation and Control System............ 7-14

7.1.5 Description of POC PIant....................... 7-19

7.1.6 Plant Operation............................ 7-36

7.1.7 Required Development...................... 7-38

7.1.8 Conceptual Design Review of POC Plant............ 7-42

7.2 Commercial Plant (200 Ton/Hour).............. 7-42

7.2.1 Requirements......................... $7-43$

7.2.2 Discussion of System (Figure $7.2 .2-1$ ).......... 7-44 
TABLE OF CONTENTS (Cont'd.)

Section

Page No.

Description of Plant.

$7-44$

7.2 .4

Budgetary Cost Estimate.

$7-49$

7.3

Waste Stream Recovery Plant (50-Ton/Hour)

7-50

7.3 .1

Requirements.

7-50

7.3 .2

Discussion of System (Figure 7.3.2-1).

7-52

7.3 .3

Description of Plant...

7-52

7.3 .4

Budgetary Cost Estimate.

7-55

8.0

Economic Studies.

8-1

8.1

Economic Model.

8-1

8.2

Economic Study Results.

8-1

8.2 .1

ROM Plant.

8-3

8.2 .2

Waste Recovery Plant.

8-7

9.0

Summary, Conclusions, and Recommendations...

9-1

9.1

Summary

9-1

9.2

Conclusions.

9-4

9.3

Recommendations

9-6

Appendices

$\begin{array}{ll}\text { A } & \text { Washability Data } \\ \text { B } & \text { Results from Fixed Volume Batch Test } \\ \text { C } & \text { Results from Variable Volume Batch Test } \\ \text { D } & \text { Results from Continuous Research Unit } \\ \text { E } & \text { Listing for LIPSA } \\ \text { F } & \text { Listing for LIPSB } \\ \text { G } & \text { Conceptual Plant Details }\end{array}$


Figure No.

Page No.

$3.0-1$

Calibration for Particle Size for Coal \#1 -

Upper Freeport.......................... $3-3$

3.0-2 Particle Size Distributions for Coal \#1 -

Upper Freeport.......................... $3-4$

3.0-3 Kcal $/ \mathrm{Kg}$ Versus Ash Content for Three Coals -

Upper Freeport, Pittsburgh \#8, and

Ill ino is \#6.............................. $3-7$

3.1-1 Batch Research Unit (BRU) ................. 3-9

3.1-2 Photograph of Batch Research Unit........... 3-10

3.1.3-1 Effect of Impeller Speed in BRU Tests......... 3-13

3.1.3-2 Effect of Settling Time in BRU Tests.......... 3-14

3.1.3-3 Effect of Contact Time in BRU Tests........... 3-16

3.1.3-4 Effect of Slurry Concentration in BRU Tests.... 3-17

3.1.3-5 Variation in Operation Parameters in BRU

Tests................................. $3-21$

3.2.1-1 Variable Volume Batch Unit............... 3-25

3.2.1-2 Photograph of the Research Development Unit

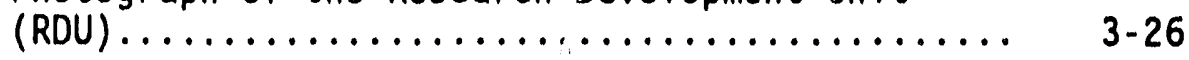

3.2.3-1 Effect of Impeller Speed in RDU Tests......... 3-29

3.2.3-2 Effect of $\mathrm{CO}_{2}$ Flowrate in RDU Tests.......... 3-31

3.2.3-3 Heating Value Recovery as a Function

of Particle Size.......................... 3-33

3.2.3-4 Separation Characteristics as a Function of

Particle Size - Illinois \#6 Coal............. 3-35

3.2.3-5 Separation Characteristics as a Function of

Particle Size - Middle Kittanning Coal........ 3-36

3.2.3-6 Multistage Separation Column.............. $3-42$

3.2.3-7 Single-Stage Versus Two-Stage Performance -

Upper Freeport Coal (Pyrite Content).......... $3-4^{n}$ 
LIST OF FIGURES (Cont'd.)

Fiqure No.

Page No.

3.2.3-8

Single-Stage Versus Two-Stage Performance -

Upper Freeport Coal (Ash Content)........... 3-44

$3.2 .3-9$

Moisture Content as Function of Speed.

$3-46$

3.2.5-1

Comparison with Washability Curve for Coal \#1 -

Upper Freeport-A (Ash in Clean Coal)............

$3-49$

$3.2 .5-2$

Comparison with Washability Curve for Coal \#1 Upper Freeport-A (Pyritic Sulfur in Clean

Coal).

$3.2 .5 \cdot 3$

Comparison with Washability Curve for Coal \#3 -

Upper Freeport-C (Ash in Clean Coal)............

3.2.5-4 Comparison with Washability Curve for Coal \#6 -

Middle Kittanning (Ash in Clean Coal).......... 3-53

3.2.5-5 Comparison with Washability Curve for Coal \#7 -

Illinois No. 6-A (Ash in Clean Coal).......... 3-54

3.3.1-1 Modified Batch Research Unit

(Screen Agglomeration) .................. 3-55

4.1-1

Continuous Research Unit (CRU) Flow Diagram.....

4-2

4.1-2

Photograph of the CRU.

4-3

4.1-3

Separation Column

4-4

4.1-4

Premixing Tank

4-6

4.1-5

Clean Coal Filter.

4-8

4.2-1

Interface Position Control

4-12

4.2-2

Refuse Discharge Control

4-13

4.2-3

Liquid $\mathrm{CO}_{2}$ Flowrate Control

4-14

4. $2-4$

Clean Coal Discharge Control

4-16

4.3-1

Results of Test 31

4-19

4.3-2

Comparison with Washability Curve for $1.76 \times 10^{-4}$

$\mathrm{kg} / \mathrm{s}(1.4 \mathrm{lb} / \mathrm{hr})$ with Upper Freeport Coa1..... 4.26

4.3-3

Comparison with Washability Curve for $3.78 \times 10^{-4}$ $\mathrm{kg} / \mathrm{s}(3 \mathrm{lb} / \mathrm{hr})$ Tests with Upper Freeport Coal... 
LIST OF FIGURES (Cont'd.)

Eiqure No.

Page No.

4.3-4

Pyritic Sulfur in Product as Function of Heating Value Recovery for Upper

Freeport Coal......................... 4-29

4.3-5 Effect of Coal Feed Rate on Process

Performance.............................. 4-30

4.3-6 Comparison with Washability Curve for

Pittsburgh No. 8 Coal....................... 4-31

4.3-7 Comparison with Washability Curve for

Illinois No. 6 Coal....................... 4-32

$5.1-1 \quad 0.006 \mathrm{~kg} / \mathrm{s}(50 \mathrm{lb} / \mathrm{hr})$ Separation Column....... 5-2

6.1-1 Integrated Statepoint Diagram............. 6-2

6.2-1 Separator Radii, 1-Ton/Hr Plant

$10 \%$ Slurry Concentration.................. $6-7$

6.2-2 Separator Radii, 1-Ton/Hr Plant

$20 \%$ Slurry Concentration................... $6-8$

6.2-3 Separator Radil, 1-Ton/Hr Plant

$30 \%$ Slurry Concentration.................. 6-9

6.2-4 Separator Radii, 1-Ton/Hr Plant

500 Seconds Residence Time................. 6-10

6.2-5 Separator Radii Vs. Residence Time

$100 \mathrm{Lb} / \mathrm{Hr}$ and $30 \%$ Slurry Concentration........ 6-12

6.2-6 Separator Radii Vs. $\mathrm{CO}_{2} /$ Slurry Ratio......... 6-14

7.1.1-1 LICADO Plant Simulation, Upper Freeport Coal... 7-4

7.1.3-1 LICADO, 1-Ton/Hour Proof-of-Concept Piping

\& Instrumentation Diagram.................... 7-11

7.1.5-1 LICADO, 1-Ton/Hour Proof-of-Concept Plant

Preliminary Plant Arrangement, Waltz Mill Site.. 7-23

7.1.5-2 LICADO, 1-Ton/Hour Proof-of-Concept Plant

Preliminary Plant Arrangement, Waltz Mill Site

Section A-A........................... 7-25

7.1.5-3 Grinding Systems Elevation............... 7-27 
Eiqure No.

7.1.5-4

7.1.5-5

7.1.5-6

7.1.5-7

$7 \cdot 1 \cdot 7.2-1$

$7.1 .7 .2-2$

7.2.2-1

7.3.2-1

8.2-1

$8.2-2$

8.2-3

$8.2-4$

8.2-5

$8.2-6$
Hydraulic Line Mixer.

Mixer Orifice Details.

Integral Multistage Separator.

Continuous Auger Filter...

Continuous Filter - Pressurized.

Sections $A-A$ and $B-B$.

LICADO, 200 Ton/Hour Commercial Plant

Flow Schematic.

50 Ton/Hour $\mathrm{CO}_{2}$ Agglomeration Process

Flow Sheet.....

LICADO Product Sales Price

Effect of After Tax ROI.

LICADO Product Sales Price

Effect of Capital Cost on 200 Ton/Hour Plant....

LICADO Product Sales Price

Effect of Plant Capacity.

LICADO Product Sales Price

Effect of Capital Cost on 50-Ton/Hour

Waste Recovery Plant.

LICADO Product Sales Price

Effect of $\mathrm{CO}_{2}$ Cost on 50-Ton/Hour

Waste Recovery Plant.

LICADO Product Sales Price

Effect of Plant Capacity on 50-Ton/Hour

Waste Recovery Plant.
8-5

8-6

8-8

8-9

Page No.

7-29

7-31

7-33

7-35

7-40

7-41

7-45

7-53

8-4

8-11 


\section{LIST OF TABLES}

Table No.

P'age No.

$3.0-1$

Ash and Sulfur Contents of Test Coals......... 3-1

$3.0-2$

Contact Angle of Water on Coal Pellets........ 3-5

$3 \cdot 1 \cdot 3-1$

Statistical Experimental Arrangement......... 3-18

$3 \cdot 1 \cdot 3-2$

Values of Three Lavels of Particle Size

in BRU Experiments.

$3 \cdot 1 \cdot 3-3$

Heating Value Recovery Analys is of Variance

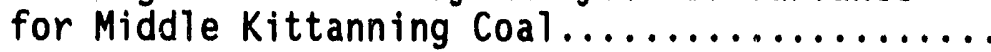

$3 \cdot 1 \cdot 3-4$

Ash Reduction Analysis of Variance

for Middle Kittanning Coal............... 3-20

$3 \cdot 1 \cdot 3-5$

Extent of Influence of Operating Variables

on Heating Value Recovery and Ash Reduction

Confidence Levels $(\%)$

$3 \cdot 2.3-1$

Range of Process Operating Conditions in

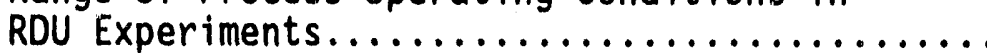

RDU Experiments with Upper Freeport Coal

Effect of Premixing Time in RDU Operation.

$3-32$

$3.2 .3-4$

Effect of Particle Size and Dispersant in

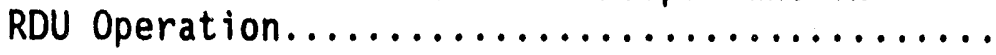

Effect of 1-Octanol on Test Coals.

Two-Step Experiments with Illinois No. 6

Coal................................ 3-40

3.2.3-7 Two-Step Experiments with Middle Kittanning

Coa1............................... 3-41

3.2.4-1 Pyrite and Ash Content at $85 \%$ Heating Value

Recovery......................... 3-47

3.3.3-1 Screen Agglomeration Experiments with Various

Coals............................ 3-57

3.3.3-2 Effect of Agitation Speed.............. 3-58 


\section{LIST OF TABLES (Cont'd.)}

Table No.

Page No.

$3.3 .3-3$

Effect of Agitation Speed on Samples of

Narrow Particle Size Distribution

(74 × 44 Microns)

$3 \cdot 3 \cdot 3-4$

Screen-type Agglomeration Experiments with 1-0ctanot...

Range of Operating Conditions in CRU

$4 \cdot 3-2$

CRU Tests with Upper Freeport Coal (coal \#3)....

$4.3-3$

Contact Angle Results for Upper Freeport

Coal Samples.

$4.3-4$

Effect of Liquid $\mathrm{CO}_{2}$ Injection Rate into

the Separation Column and the Slurry Injection

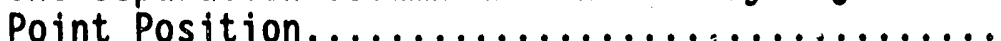

$4.3-5$

Effect of Liquid $\mathrm{CO}_{2}$ Injection into the

Premixing Tank.

$4 \cdot 3-6$

Effect of the Interface Position.

Effect of the Premixing Tank Mixing Speed.

Effect of Liquid $\mathrm{CO}_{2}$ Distribution.

Measurements Requirements l.ist 


\subsection{INTRODUCTION}

This is the Final Report summarizing technical progress from inception on October 1, 1987 through completion on Apri1 2, 1990 on Development of the LICADO Coal Cleaning Process, Contract DE-AC22-87PC79873, sponsored by the U.S, Department of Enargy, Pittsburgh Energy Technology Center (PETC). The Westinghouse Advanced Energy Systems Division is the prime contractor for this project, with the University of Pittsburgh as the major subccintractor.

The LICADO (LIquid CArbon Dioxide) process is a novel, advanced coal cleaning method conseived and patented by the University of Pittsbursi. Liquid carbon dioxide at high pressure (about 850 psia) and room temperature is used to separate clean coal from an aqueous suspension, leaving the $a_{-} h$ and pyrite constituents in the water phase. Since liquid $\mathrm{CO}_{2}$ is immiscible in water, wets clean coal particies, and does not wet ash or pyrite particles, these properties result in the separation of clean coal from the water, ash, and pyrite at the liquid $\mathrm{CO}_{2}$-water interface. The effectiveness of this process has been demonstrated in bench-scale batch tests at the University of Pittsburgh prior to the initiation of this project. These initial tests resulted in removal of up to $90 \%$ of the ash and pyritic sulfur.

The program is organized into six tasks, which are 1 isted below with the responsible organization and personnel for each task:

DOE Technical Project Officer: Dr. R. W. Lai

Westinghouse Project Manager: Dr. M. H. Cooper

University of Pittsburgh Project Manager: Dr. S. H. Chiang

University of Pittsburgh Principal Investigator: Dr. R. Venkatadri 
Task 1. Batch Rasearch Unit - University of Pittsburgh

Dr. B. Morsi, Task Leader

Ms. M. T. Thach

Mr. D. X. He'

Mr. Y. Ou

Task 2. Continuous Research Unit - University of Pittsburgh

Dr. G. E. Klinzing, Task Leader

Mr. G. Araujo

Mr. Y. Feng

Task 3. Continuous Unit - University of Pittsburgh

Dr. G. E. Klinzing, Task Leader

Mr. G. Araujo

$\mathrm{Mr}$. Y. Feng

Task 4. Modeling and Evaluation - Westinghouse

Dr. M. H. Cooper, Task Leader

Task 5. Proof-of-Concept Plant - Westinghouse

Dr. M. H. Cooper, Task Leadel'

Mr. H. O. Muenchow

Mr. D. K'. Stimmel

Task 6. Economic Analyses - Wostinghouse

Mr. J. D. Mottley, Task Leader

Ms. E. H. Valkovic

Mr. C. W. Mycoff

This report provides a detailed description of the technical results of each of these tasks. 


\subsection{OBJECTIVES}

The objectives of this project are: 1) the development of an effective and efficient advanced technique for cleaning fine coal based on the LICADO proce;s, and 2) the testing of the najor unit operations of this process on an integrated, continuous real time basis.

These goals will be achiever by establishment of technical feasibility through generation of a firm engineering data base from additional batch testing, small scale continuous unit testing $(1-1 \mathrm{~b} / \mathrm{hr}$ to $10-1 \mathrm{~b} / \mathrm{hr})$, economic analysis, and design of a one ton per hour Proof-of-Concept plant. 


\subsection{EXPERIMENTAL PROGRAM FOR BATCH TESTS}

The experimental program for the batch tests consisted of three major components described in the following sections.

- Fixed volume batch tests in the $0.05 \mathrm{~m}$ (2-inch) Batch Research Unit (BRU).

- Variable volume batch tests using the $0.10 \mathrm{~m}$ (4-inch) Research Development Unit (RDU).

- Fixed volume agglomeration/screening tests in the $0.05 \mathrm{~m}$ (2-inch) Batch Research Unit (BRU).

\section{COAL SAMPLES}

Eight different coals were tested in the batch tests. Table 3.0-1 shows the ash and sulfur contents of each of these coals. The washability analysis for -74 microns (-200 mesh) samples of coals No. $1,3,6$ and 7 are provided in Appendix A.

TABLE 3.0-1

ASH AND SULFUR CONTENTS OF TEST COALS

\begin{tabular}{|l|l|c|c|c|}
\hline No. & Coal & Ash(\%) & $\begin{array}{c}\text { Total } \\
\text { Sulfur(\%) }\end{array}$ & $\begin{array}{c}\text { Pyritic } \\
\text { Sulfur(\%) }\end{array}$ \\
\hline \hline 1. & Upper Freeport (A) & 24.4 & 1.4 & 1.1 \\
2. & Upper Freeport (B) & 22.7 & 1.4 & 1.1 \\
3. & Upper Freeport (C) & 13.5 & 2.2 & 1.7 \\
4. & Pittsburgh-Bruceton & 4.9 & 1.6 & 0.7 \\
5. & Pittsburgh & 31.5 & 1.9 & 1.3 \\
6. & Middle Kittanning & 7.9 & 5.0 & 3.8 \\
7. & Illinois No.6 (A) & 26.0 & 3.9 & 2.7 \\
8. & Illinois No.6 (B) & 12.6 & 3.1 & 2.0 \\
\hline \hline
\end{tabular}

In addition to the above, a Pittsburgh \#8 coal was used in tests conducted in the Continuous Research Unit. The feed ash content of this coal was $12.2 \%$, with total sulfur and pyritic sulfur contents of $4.3 \%$ and $3.15 \%$, respectively. 
SAMPLE PREPARATION AND PARTICLE SIZE ANALYSIS

A11 samples of coal were first ground in a jaw crusher to the size range $0.004 \mathrm{~m} \times 0\left(3 / 16^{\prime \prime} \times 0\right)$. Further size reduction was achieved by wet grinding with a stirred ball mill supplied by Fort Pitt Machine Company. A standard procedure was adopted for grinding. The feed to the stirred ball $\mathrm{mill}$ was varied from $0.227 \mathrm{~kg}(0.5 \mathrm{lb})$ to $1.81 \mathrm{~kg}(4 \mathrm{lbs})$, and the slurry concentration ranged from 5 to $40 \%$ solid. The grinding was achieved by using $0.004 \mathrm{~m}(3 / 16 ")$ stainless steel balls as the grinding medium. The speed of rotation of the impeller was fixed at $52.3 \mathrm{rad} / \mathrm{s}(500 \mathrm{rpm})$. The samples were ground for various periods ranging from $60 \mathrm{~s}$ to $2400 \mathrm{~s}$. Samples were withdrawn at regular intervals during the grinding, and the particle size distribution was determined with a Leitz orthoplan microscope coupled to an image analyzer. These results were used to construct a calibration curve for mean particle size of the coal sample as a function of grinding time. Based on this information, samples were ground to requisite times to obtain a desired particle size for subsequent beneficiation.

Figure 3.0-1 shows a typical grinding curve (Upper Freeport coal). A sharp decrease in the average particle size can be observed during the initial $300 \mathrm{~s}(5 \mathrm{~min})$ cf grinding as the weight mean diameter is reduced from 150 microns to approximately 50 microns. Subsequent grinding to 2400 $s(40 \mathrm{~min})$ resulted in a steady but slow decrease in particle size. The distribution in particie size for Upper Freeport coal is displayed for various grinding periods in Figure 3.0-2. The distribution of fine particles below 40 microns increases correspondingly with longer grinding periods concomitant with decreases in the percentage of large particles (above 150 microns).

SURFACE PROPERTY MEASUREMENTS

Surface wettability is an important property for the LICADO process and can be characterized by measurement of contact angie on coal surfaces. Contact angle measurements were carried out at room temperature and 


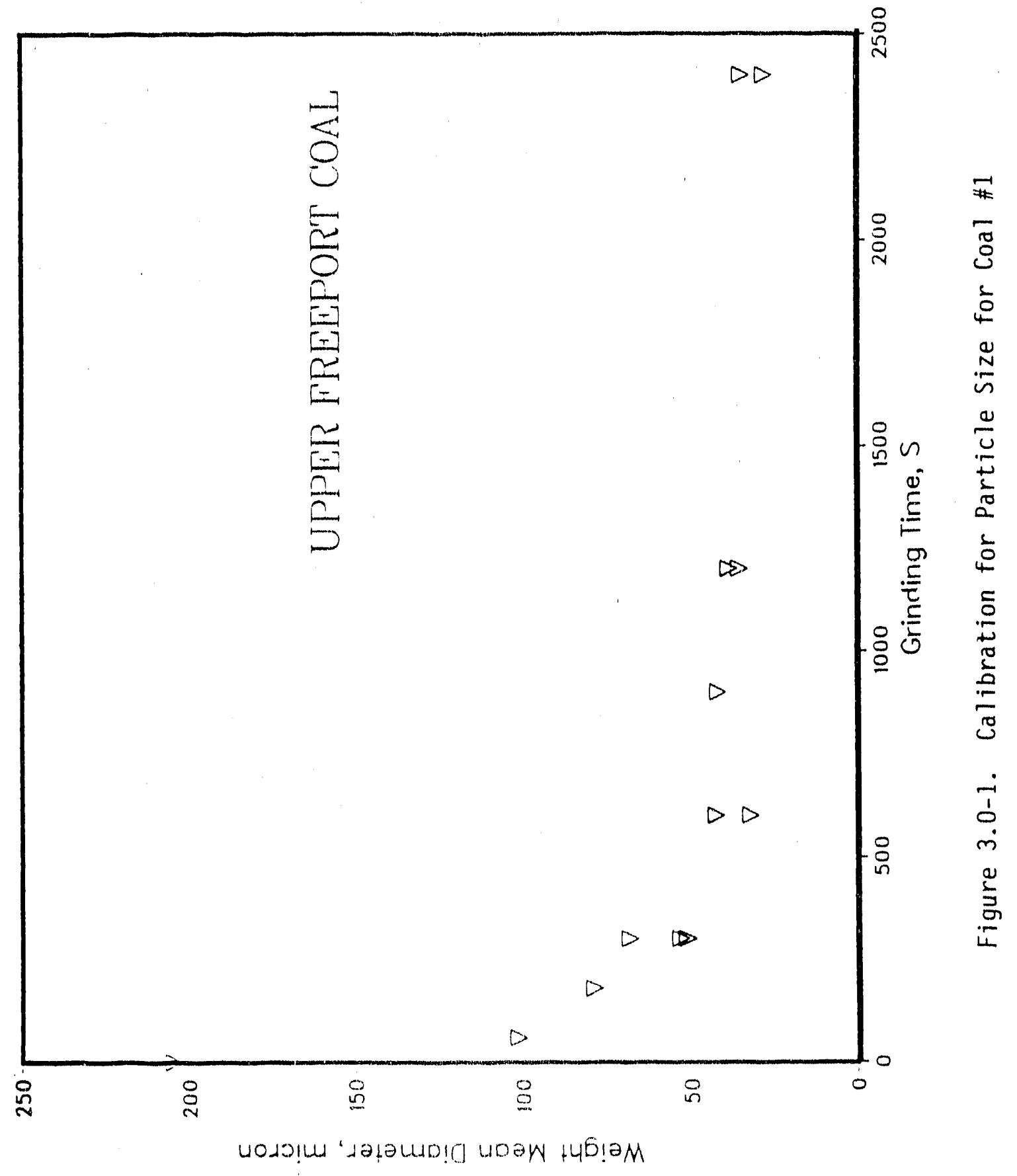




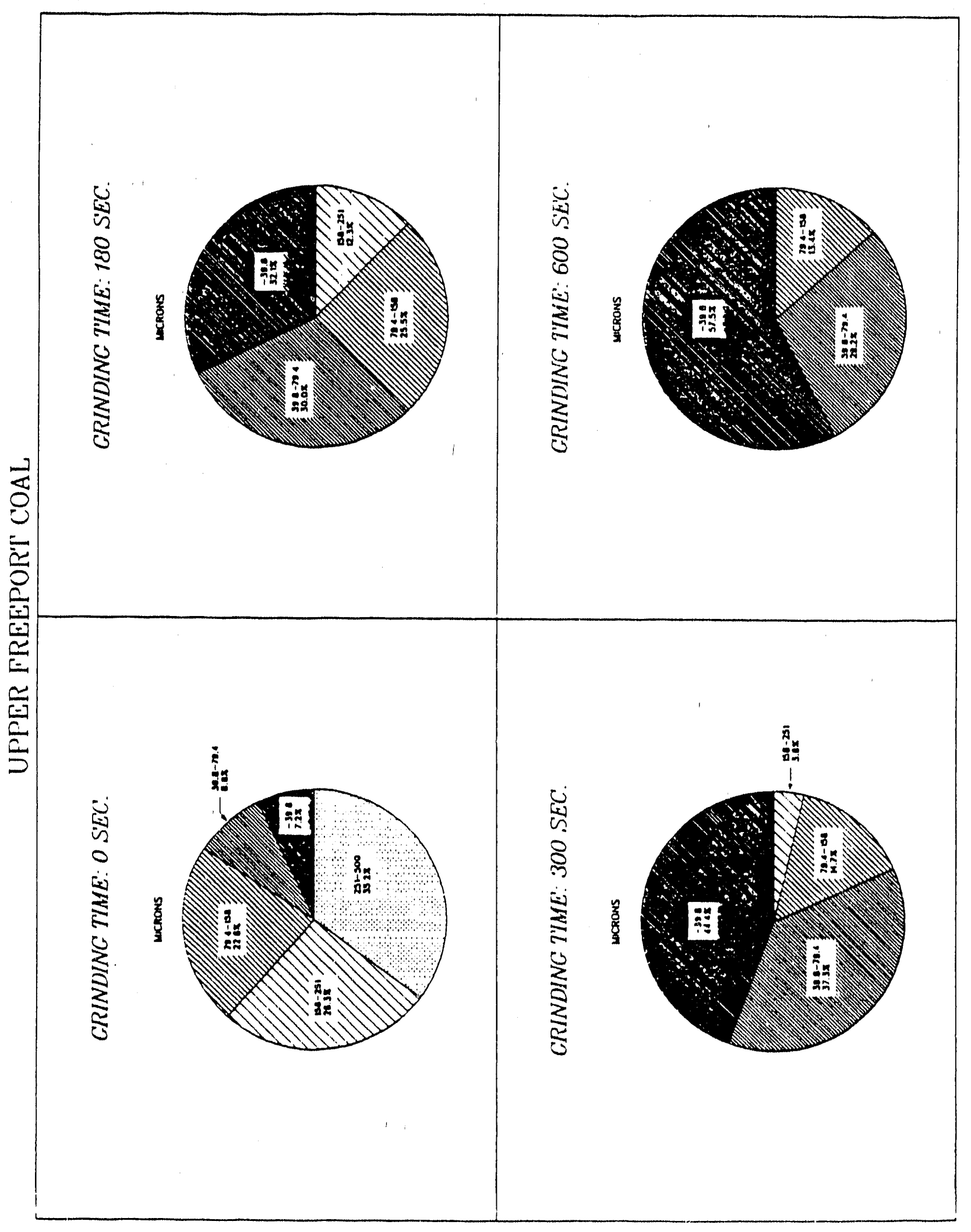

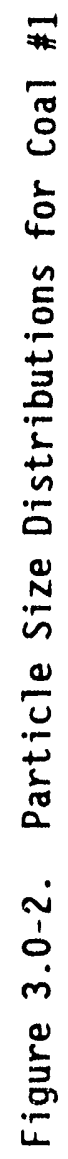


ambient pressure using a conventional goniometer by the standard sessile-drop technique. Coal samples were pelletized in a Buehler Pelletizer at $27.6 \mathrm{MPa}(4000 \mathrm{psi})$, and the advancing contact angle of water on these prllets was measured. The contact angle of water was subsequently measured in a specially designed high pressure chamber in the presence of liquid $\mathrm{CO}_{2}$. The results for three coals utilized in this project are compared in Table 3.0-2.

It can be observed from Table 3.0-2 that Upper Freeport coal and Middle Kittanning coal exhibit a hydrophobic character, as evidenced by the large contact angles at atmospheric pressure. Liquid $\mathrm{CO}_{2}$ imparts further hydrophobicity to these coals since the contact angles exceed 140 degrees. However, the Illinois No. 6 coal exhibits zero contact angle at room temperature and pressure, which is indicative of the extreme hydrophilic nature of the sample. Even in the presence of liquid $\mathrm{CO}_{2}$, a contact angle of only 75 degrees was registered, showing that the sample retained a substantial portion of its hydrophilic character. Experimental results from the Batch Research Unit (BRU), Research Development Unit (RDU) as well as the Continuous Research Unit (CRU) tests confirmed these observations.

TABLE 3.0-2

CONTACT ANGLE OF WATER ON COAL PELLETS

\begin{tabular}{|c|c|c|}
\hline \multirow{2}{*}{ Coal } & \multicolumn{2}{|c|}{ Equilibrium Contact Angle, Degrees } \\
\cline { 2 - 3 } & Atm pressure & In Liquid $\mathrm{CO}_{2}$ \\
\hline \hline $\begin{array}{c}\text { Upper Freeport } \\
\text { (coal \#1) } \\
\text { Middle Kittanning } \\
\text { (coal \#6) } \\
\begin{array}{c}\text { Ilinois No. 6 } \\
\text { (coal \#7) }\end{array}\end{array}$ & 108 & 145 \\
\hline
\end{tabular}




\section{PERFORMANCE CRITERIA}

The performance of the LICADO process was characterized in terms of heating value recovery, ash reduction and pyritic sulfur reduction. Heating value (Btu) recovery is expressed in terms of the clean coal yield.

$$
\text { Heating value recovery }(\%)=\text { Yield }(\%) \times \frac{(100-\text { Clean Coal Ash })}{\left(100-\text { Feed Coat } \frac{\text { Ash })}{4}\right.}
$$

The validity of this relationship was independently verified by experimentally measuring heating value recovery as a function of ash content in a companion DOE project (3-1). Figure 3.0-3 shows that the heating value is directly proportional to the ash-free coal (or clean coal yteld). Based on this, the above relationship can be used to compute the heating value recovery for test results.

The ash and pyritic sulfur reduction are defined as:

$$
\begin{aligned}
& \text { Ash Reduction }(\%)=100-\frac{\text { Product coal ash content }}{\text { Feed coal ash content }} \times 100 \\
& \text { Pyritic Sulfur Reduction }(\%)= \\
& 100-\frac{\text { Product coal pyritic sulfur content }}{\text { feed coal pyritic sulfur content }} \times 100
\end{aligned}
$$




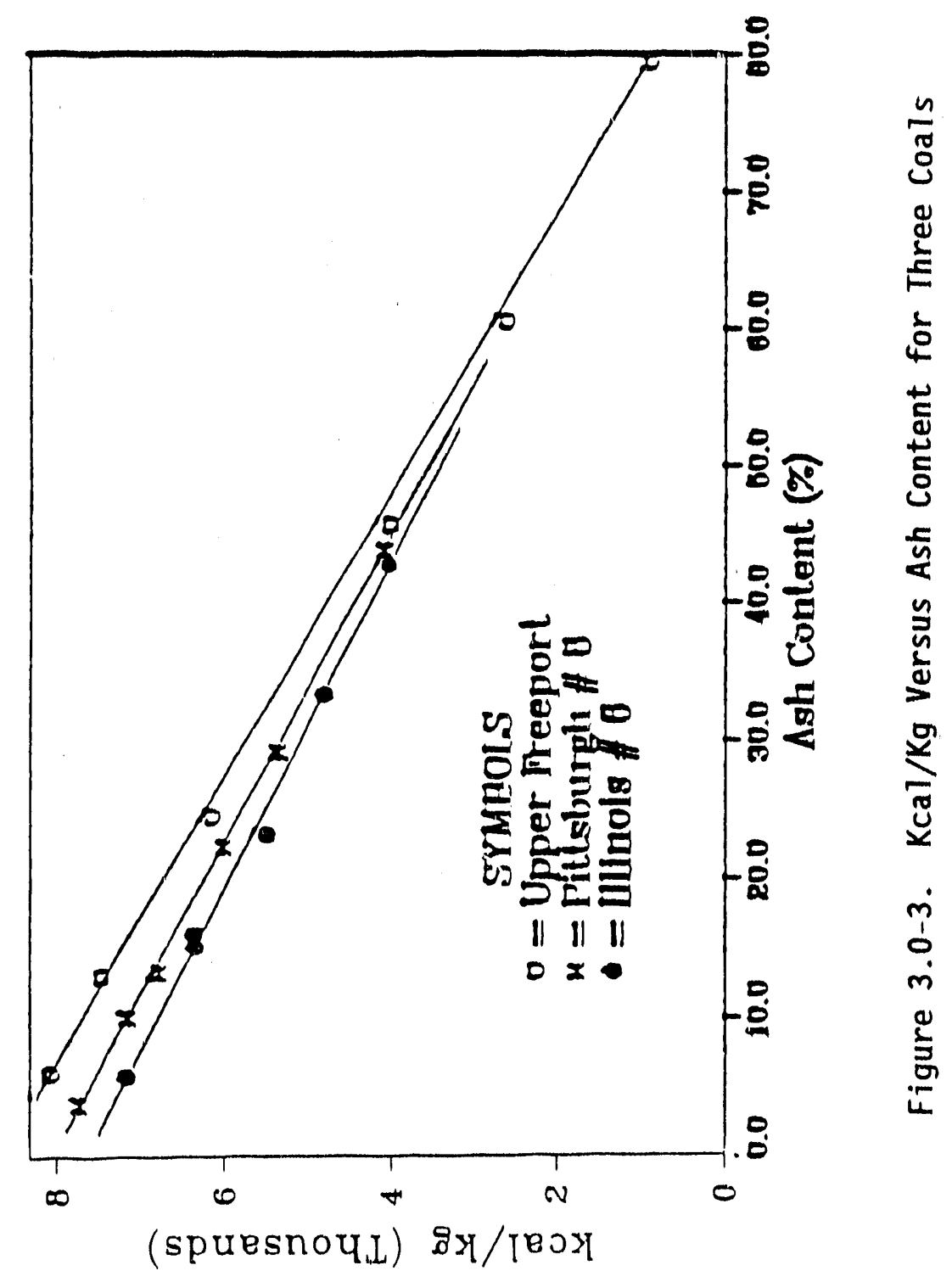


In addition, the process performance may also be measured by the ash and pyritic sulfur rejection, which are defined as follows:

$$
\begin{aligned}
& \text { Ash Rejection }(\%)=100-\left(Y \times \frac{\text { ash in product }}{\text { ash in feed }}\right) \\
& \text { Pyritic Sulfur Rejection }(\%)= \\
& 100-\left(Y \times \frac{\text { pyritic sulfur in product }}{\text { pyritic sulfur in feed }}\right)
\end{aligned}
$$

where $Y$ is the experimentally measured yield in wt\%.

The average diameters of coal feed samples were measured with a Leitz Orthoplan microscope coupled with an image analyzer. Two types of average diameters were measured: the volume surface mean diameter and the weight mean diameter. The equations defining these two quantities are provided in the last part of Appendix $A$. The volume surface mean diameter corresponds to the diameter of a sphere having the same ratio of volume/surface area as the particle. The weight mean diameter is the average of the weight distribution of the particles.

\subsection{Eixed Volume Batch Tests}

Extensive testing of the LICADO process was conducted in the fixed volume batch mode using the $0.05 \mathrm{~m}(2$-inch) Batch Research Unit (BRU). This section describes the equipment and experimental procedure as well as the major conclusions from the fixed volume batch tests. In the fixed volume batch tests, the slurry volume is maintained constant, and liquid $\mathrm{CO}_{2}$ does nist leave the system during the duration of the test.

\section{1 .1 Groutpment}

The Batch Research Unit is shown in Figures 3.1-1 and 3.1-2. The apparatus, whing has a capacity of about $0.003 \mathrm{~m}^{3}$ (3 liters), consists of two highrpressure cells of $0.05 \mathrm{~m}(2$-inch) I.D. connected by a $0.05 \mathrm{~m}$ (2-inch) hall valve. The size of the opening of the ball valve was chosen to be the same as the internal diameter of the cells to eliminate any 


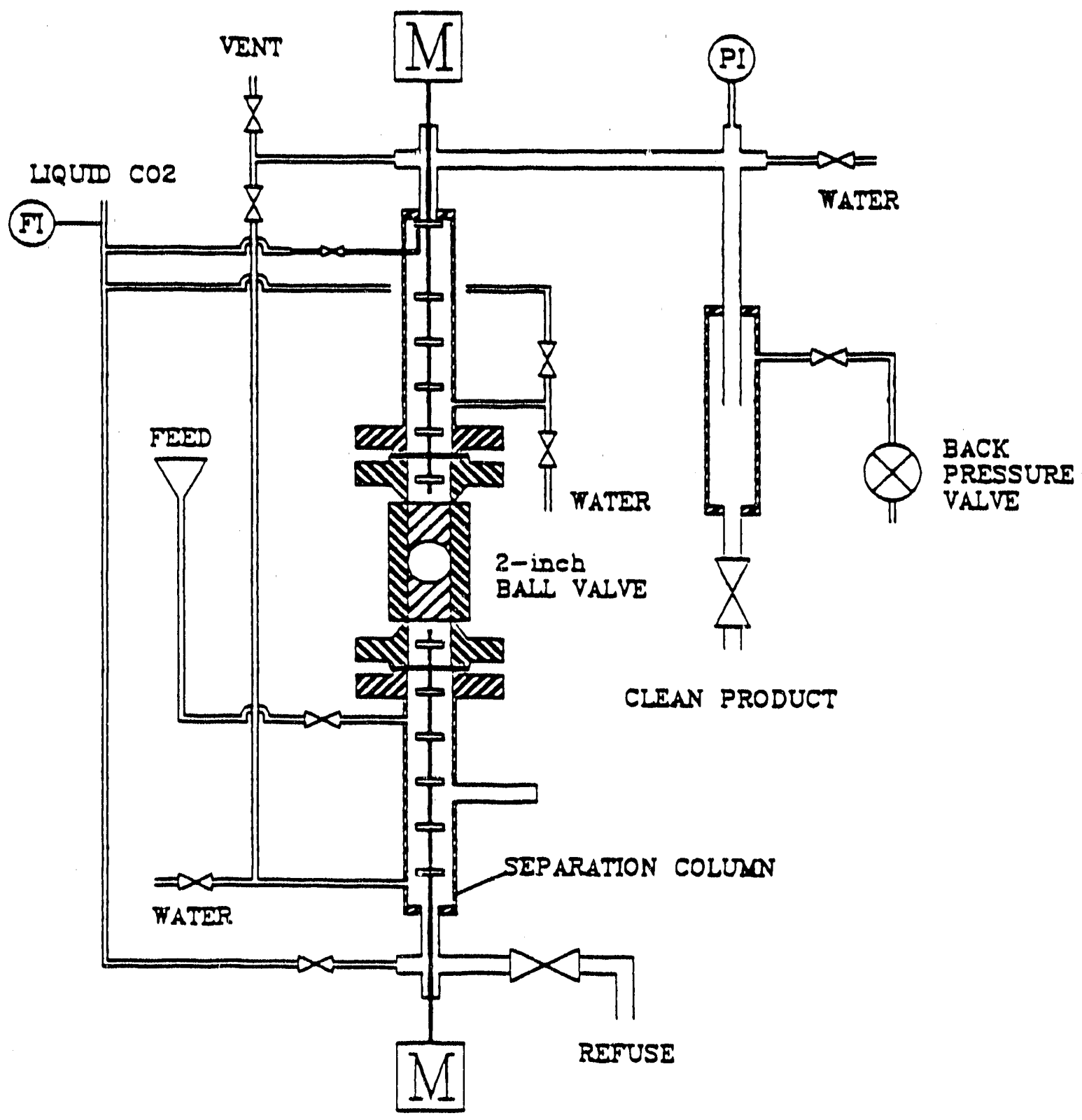

Figure 3.1-1. Batch Research Unit (BRU) 


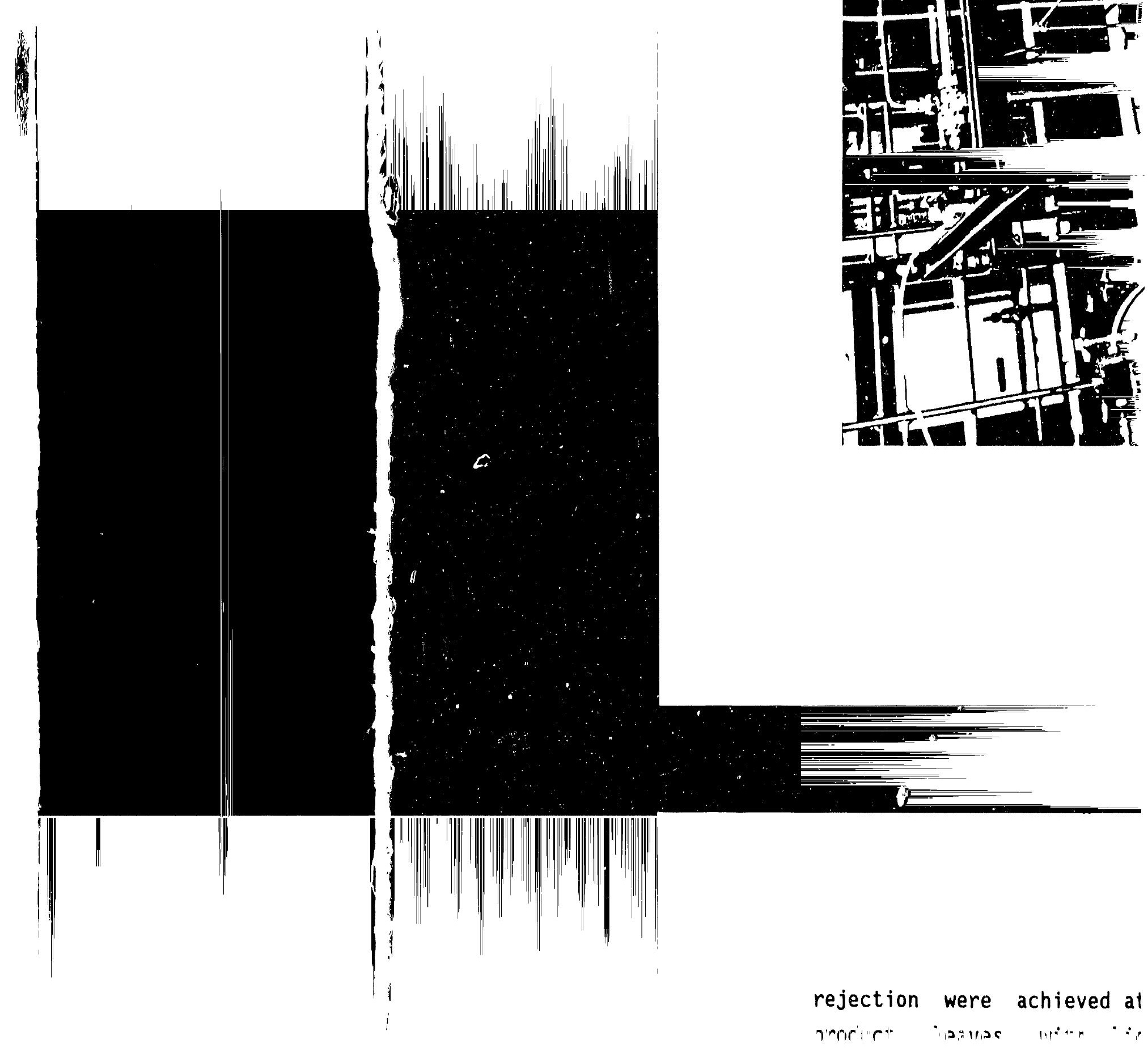


physical obstructions to the movement of coal slurry between the two cells. The valve allows a quick and complete isolation of the two high pressure vessels. Thus, clean coal and refuse can be removed completely without any remixing when the system is depressurized. Other features of the BRU include:

- Transparent windows on upper and lower cells for visual observation.

- Two variable speed mixers up to $314 \mathrm{rad} / \mathrm{s}$ (3000 rpm) to provide adequate mixing in both the liquid $\mathrm{CO}_{2}$ and water phases.

- A micron-size fritted disc distributor located at the bottom of the lower cell to provide a uniform dispersion of the liquid $\mathrm{CO}_{2}$ droplets within the water phase.

\subsubsection{Procedure}

The coal water slurry of $0.0009 \mathrm{~m}^{3}(0.9$ liters $)$ was prepared at various slurry concentrations of coal. It was mixed for a sufficient time to achieve complete wetting of the coal particles with water. The slurry was then manually fed to the BRU, and the system was pressurized to the desired operating pressure of 5.5-6.2 MPa (800-900 psig). Liquid $\mathrm{CO}_{2}$ was introduced from the top cell until it saturated the slurry and the excess $\mathrm{CO}_{2}$ forms a thin layer above the coal-water-liquid $\mathrm{CO}_{2}$ interface. Premixing of the slurry was then carried out for 60 $s$ at an agitation speed of $104 \mathrm{rad} / \mathrm{s}$ (1000 rpm) in both the upper and lower test cells. Subsequently, liquid $\mathrm{CO}_{2}$ was injected into tine slurry from the bottom of the unit while constant mixing was maintained in both phases. After a predetermined contact time $(0-600 \mathrm{~s})$, the mixing in both phases was stopped. The clean coal was allowed to separate from the refuse for a certain length of time, denoted as settling time (usually 300 s). The central ball valve was closed, and the system was depressurized to ambient pressure. The clean coal was removed from the top cell while the refuse was removed from the bottom cell. 


\subsubsection{Results and Discussion}

Four different test coals were utilized in fixed volume batch tests conducted in the BRU. These included coals which have been designated in Table 3.0-1 as \#1, \#4, \#6, and \#7, respectively.

\subsubsection{Initial Study}

Initial experiments in the BRU were conducted using Upper Freeport coal (coal \#1) with a nominal particle size of -74 microns. The effect of mixing in both liquid $\mathrm{CO}_{2}$ and aqueous phases was examined by varying the impeller speed in both phases from $0-125 \mathrm{rad} / \mathrm{s}(0-1200 \mathrm{rpm})$. Figure 3.1.3-1 illustrates the results for the variation in the experimental yield and product quality with agitation speed. It can be observed that there is a significant reduction in the ash content when the impeller speed is maintained in the range of 62-105 rad/s (600-1000 rpm), while a reasonable yield was obtained. Higher speeds resulted in an increase in the ash content of the product. The impellers in the water phase assist in breaking and better dispersion of the liquid $\mathrm{CO}_{2}$ droplets, while mixing in the upper phase improves the breaking of the agglomerates and releasing the entrained ash material from the product coal as well as reagglomeration of the particles. These results showed that mixing was necessary to the LICADO process operation. Yet, there is a range of mixing speed to achieve the most effective performance. Higher speeds result in undesirable transport of ash into the liquid $\mathrm{CO}_{2}$ phase and thus, into the product. Subsequent tests were performed at an impeller speed of $105 \mathrm{rad} / \mathrm{s}$ (1000 rpm) in both phases.

The variation in the settling time after contact with liquid $\mathrm{CO}_{2}$ was al so studied with Upper Freeport coal. Figure 3.1.3-2 shows that the zero settling time (immediate closing of the ball valve at the end of mixing) produced a high ash content. Subsequent tests were carried out for a settling time of $300 \mathrm{~s}$. The experimental results indicate that a settling period of $300 \mathrm{~s}$ was sufficient for a complete separation of bulk phases 


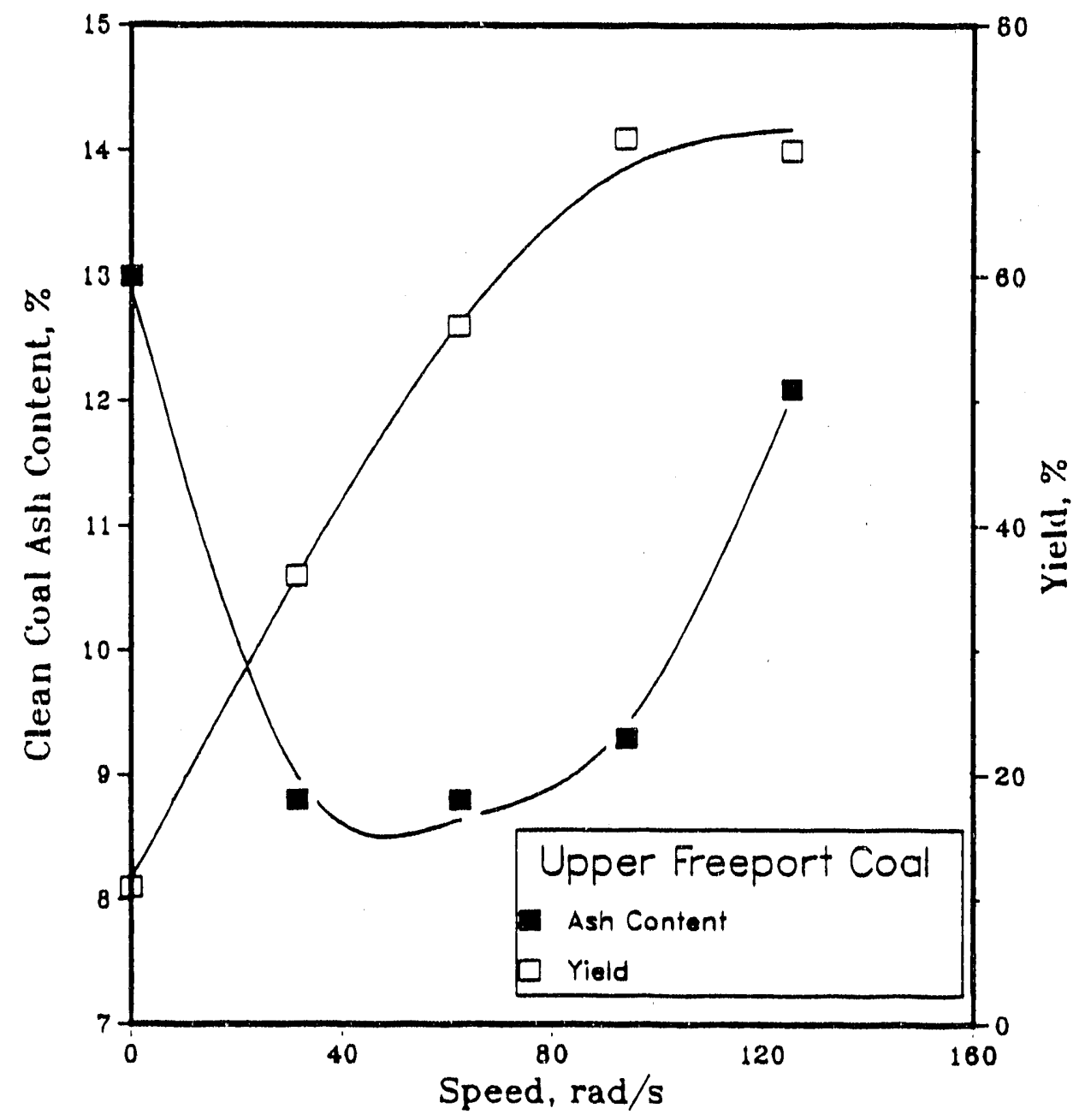

Figure 3.1.3-1. Effect of Impeller Speed in BRU Tests 


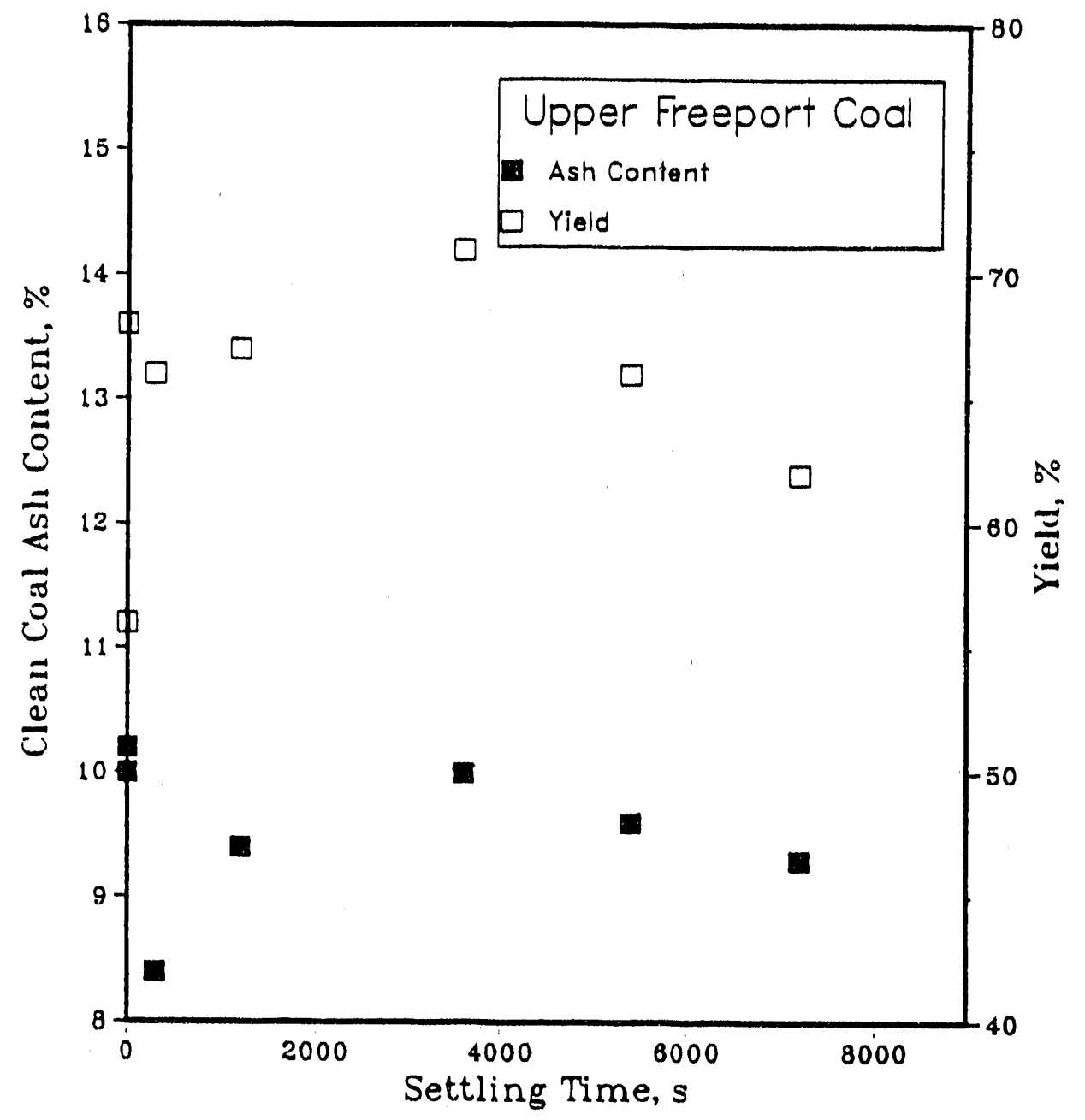

Figure 3-1.3-2. Effect of Settling Time in BRU Tests 
(i.e., the liquid $\mathrm{CO}_{2}$ and water phases) to provide a good product yield and quality. At a longer separation time, disengagement of finely dispersed liquid $\mathrm{CO}_{2}$ droplets from the water phase in the bottom cell transported refuse material into the upper phase, resulting in an increase of the yield as well as the ash content of the product. When the settling time was increased further (say, beyond $1000 \mathrm{~s}$ ), the yield tended to decrease, because of the settling of heavy agglomerates from the upper (1iquid $\mathrm{CO}_{2}$ ) phase to the lower (water) phase. Based on these observations, all subsequent tests were conducted with a settling time of 300 s.

A set of experiments was also carried out with Upper Freeport coa1, wherein the injection/mixing (contact) time was varied. Figure 3.1.3-3 shows that when the injection time was maintained at about $900 \mathrm{~s}$ (15 minutes), higher yields were achieved at fairly good separation characteristics. Longer injection times at a constant liquid $\mathrm{CO}_{2}$ flowrate increased the yield, owing to increased contact of droplets of liquid $\mathrm{CO}_{2}$ with coal. However, a decrease in the product quality was observed, suggesting that entrapment of ash material in the clean coal agglomerates was taking place.

Tests carried out at slurry concentrations varying from 3 to 17 wt\% indicated that there was essentially no effect on Upper Freeport coal. This is shown in Figure 3.1.3-4.

The important conclusions from the parametric studies in the BRU were that the mixing speed of $104 \mathrm{rad} / \mathrm{s}(1000 \mathrm{rpm})$ in both phases yielded improved results. A settling time of $300 \mathrm{~s}$ was desirable. Injection times of about $900 \mathrm{~s}$ provided favorable results. Slurry concentrations up to $17 \%$ has a relatively minor effect on the process performance. Strictly speaking, these conclusions are only valid for Upper Freeport coal (coal \#1). However, they can serve as a basis for experimental design for each of the test coals in the fixed volume batch tests. They can also be used as design guidelines for subsequent tests in both the Research Development Unit and the Continuous Research Unit. 


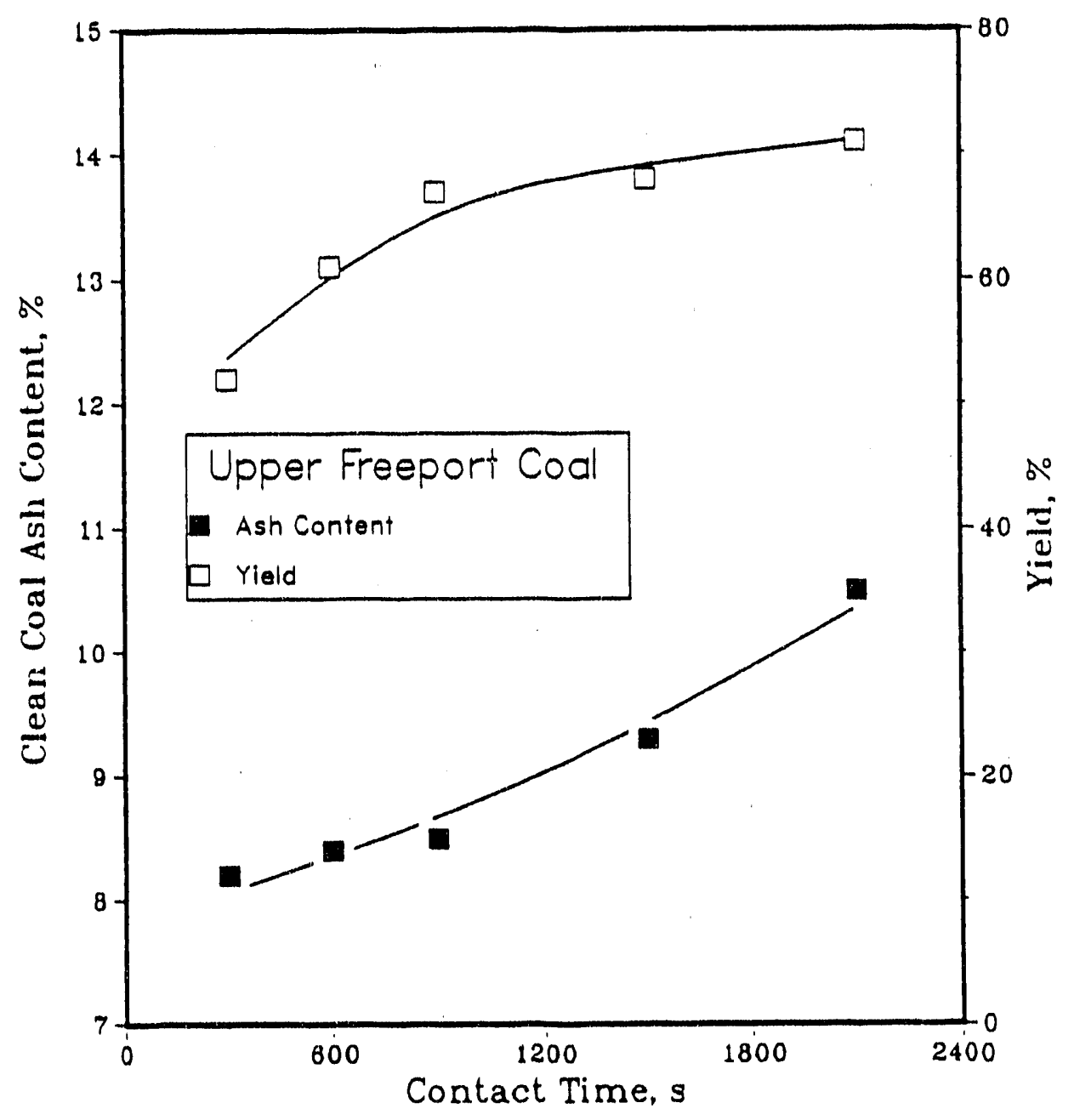

Figure 3.1.3-3. Effect of Contact Time in BRU Tests 


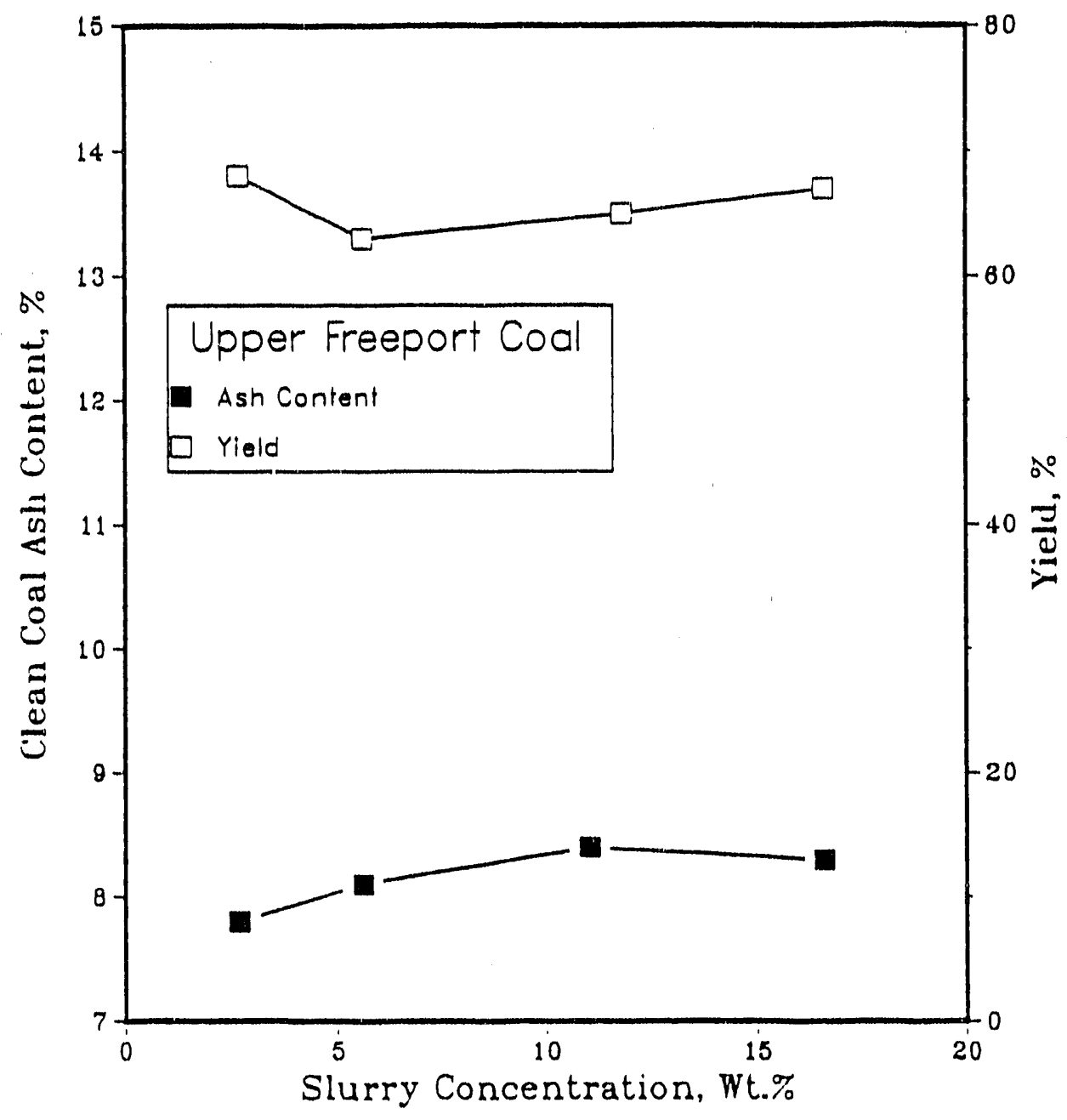

Figure 3-1.3-4. Effect of Slurry Concentration in BRU Tests 


\subsubsection{Statistically Designed Experiments}

For further investigation of the operation parameters, a $3 \times 3 \times 3$ fact.ry 4 ? design ( 3 factors, 3 levels) was employed to perform experiments for each of the three coals. This resulted in 27 experiments for each coal in addition to repeat runs. The influence of particle size, liquid $\mathrm{CO}_{2}$ flowrate, and slurry concentration on process performance was evaluated by statistical analysis of the raw data. The statistical experimental design is shown in Table 3.1.3-1.

The particle size range varied for each coal and Table 3.1.3-2 shows the range studied for each coal in the BRU experiments. The volume surface mean diameters have been reported here.

Table 3.1.3-1

Statistical Experimental Arrangement

\begin{tabular}{|c|c|c|c|}
\hline \multirow{2}{*}{ Factor } & \multicolumn{3}{|c|}{ Level } \\
\cline { 2 - 4 } & 1 & 2 & 3 \\
\hline \hline $\begin{array}{l}\text { Mean Particle Size * } \\
\text { STurry Concentration } \\
(\text { Wt\% }) \\
\begin{array}{c}\text { Liquid } \mathrm{CO}_{2} \text { Flowrate } \\
\mathrm{m}^{3} / \mathrm{s} \times 10-6\end{array}\end{array}$ & 2.5 & 5 & 10 \\
\hline \hline
\end{tabular}

* Particle sizes for each coal are given in Table 3.1.3-2.

The particle size distribution data of each coal after $180 \mathrm{~s}$ of grinding in the stirred ball mill are shown in Appendix B in Tables B-10 through $B-12$. The detailed experimental data for all the coals used in fixed volume batch tests is documented in Appendix B in Tables B-7, B-8, and B-9. 
Table 3.1.3-2

Values of Three Levels of Particle Size in BRU Experiments

\begin{tabular}{|c|c|c|c|}
\hline \multirow{2}{*}{ Coal } & \multicolumn{3}{|c|}{ Particle Size (microns) } \\
\hline & Sma11 & Medium & Large \\
\hline Pittsburgh - Bruceton & 33 & 40 & 50 \\
\hline Middle Kittanning & 28 & 38 & 97 \\
\hline Illinois No. 6 & 41 & 50 & 70 \\
\hline
\end{tabular}

A summary of the analysis of variance results for Middle Kittanning coal is given in Tables 3.1.3-3 and 3.1.3-4. A complete description of the method of statistical analysis is provided in Appendix B. Details of statistical analysis for each coal are given in Tables B-1 through B-6 in Appendix B.

Here, ss refers to the sum of squares, $s^{2}$ to the mean square for each factor considered, and the term $s^{2} /\left(s_{R}\right)^{2}$ can be related to the confidence limits which determine the statistical significance of the parameter. This term is also defined as the F-ratio. The significance of each factor is determined by comparing the F-ratio with F-distribution values provided in statistical tables (see Appendix $B$ ). When the confidence interval for a particular F-ratio exceeds $99 \%$ (or when $\mathrm{s}^{2} /\left(s_{R}\right)^{2}$ is greater than 5.85), the parameter is considered to exert a significant effect on the results.

Table 3.1.3-3 shows the analysis of variance of the heating value recovery results. The analysis of variance indicates that the heating value recovery results are influenced significantly only by the particle size at a $99 \%$ confidence level. The data show a clear trend suggesting that smaller particle size samples generate higher yields. 
Table 3.1.3-3

Heating Value Recovery Analysis of Variance

Middle Kittanning Coal

\begin{tabular}{|l|r|r|r|r|r|r|}
\hline \multirow{2}{*}{ Factor } & \multicolumn{3}{|c|}{ Level Average } & \multirow{2}{*}{ SS } & \multirow{2}{*}{$\mathrm{s}^{2}$} & \multirow{2}{*}{$\mathrm{s}^{2} / \mathrm{s}_{\mathrm{R}}^{2}$} \\
\cline { 2 - 6 } & 1 & 2 & 3 & & & \\
\hline \hline Particle Size & 52 & 63 & 75 & 2274 & 1137 & 6.73 \\
Siurry Concentration & 57 & 68 & 64 & 574 & 287 & 1.70 \\
Liquid $\mathrm{CO}_{2}$ Flowrate & 63 & 67 & 60 & 186 & 93 & 0.55 \\
\hline \hline
\end{tabular}

Table 3.1.3-4 summarizes the analys is of varlance performed for the ash reduction results. The analysis indicates that none of the studied vartables exert a signiffcant effect on the ash reduction results. To further illustrate these effects, the ash reduction and heating value recovery are plotted as a function of particle size in Figure 3.1.3-5.

Table 3.1.3-4

Ash Reduction Analysis of Variance

Middle Kittanning Coal

\begin{tabular}{|c|c|c|c|c|c|c|}
\hline \multirow{2}{*}{ Factor } & \multicolumn{3}{|c|}{ Level Average } & \multirow{2}{*}{ SS } & \multirow{2}{*}{$s^{2}$} & \multirow{2}{*}{$s^{2} / s_{R}^{2}$} \\
\hline & 1 & 2 & 3 & & & \\
\hline Particle Size & 45 & 46 & 45 & 6.3 & 3.2 & 0.30 \\
\hline Slurry Concentration & 47 & 45 & 45 & 31.2 & 15.6 & 1.48 \\
\hline Liquid $\mathrm{CO}_{2}$ Flowrate & 46 & 46 & 45 & 8.2 & 4.1 & 0.39 \\
\hline \multicolumn{4}{|c|}{ dual } & \multicolumn{3}{|c|}{10.6} \\
\hline
\end{tabular}



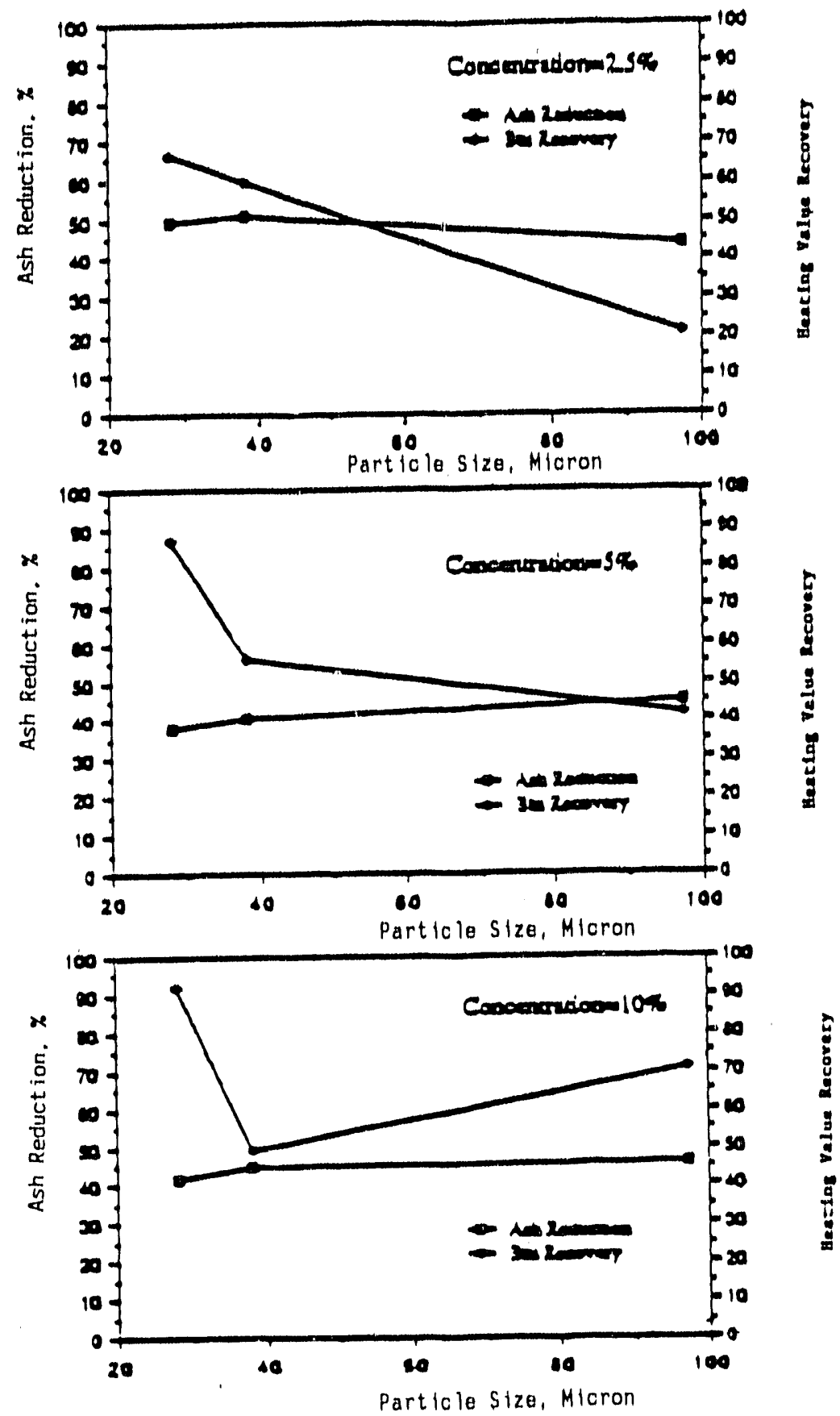

Figure 3.1.3-5. Vartation in Uperation Parameters in BRU Tests 
The data were obtained at a liquid $\mathrm{CO}_{2}$ flowrate of $0.41 \times 10.6$ $\mathrm{m}^{3} / \mathrm{s} \quad(25 \mathrm{ml} / \mathrm{m} / \mathrm{n})$. The results are presented at three different slurry concentrations. It can be observed that the heating value recovery decreases with an increase in particle stze at the lower slurry concentrattons of $2.5 \%$ and $5 \%$. The ash reduction rematris virtually unaffected by changes in operating conditions. The heating value recovery appears to increase at the higher slurry concentration.

The detafled statistical analysis results for Pittsburgh-Bruceton coal (coal \#4) and Illinots No. 6.coal (coal \#7) are provided in Appendix B. For the Illinots No. 6 coal, the results are simflar to those for Middle Kittanning coal. Smaller particle sizes generate improved heating value recovertes in the range studied. The effect on ash reduction by all process parameters is statistically insignificant. In the case of Pittsburgh-Bruceton coal, the variation in particle size (33-50 microns) was too narrow to observe any significant effect of particle size. However, the slurry concentration influenced both heating value recovery and ash reduction. Improved results were achieved at a slurry concentration of $5 \%$.'

To summarize the statistical analysis for the data from the fixed volume batch tests, Table 3.1.3-5 shows the confidence limtts for each of the coals for heating value recovery and ash reduction. The main conclusions from Table 3.1.3-5 are that particle size significantly influences the heating value recovery, especially for coals \#6 and \#7. The slurry concentration effect is pronounced for coal \#4 for both the heating value recovery and ash reduction. The $\mathrm{CO}_{2}$ flowrate does not influence either heating value recovery or the ash reductions for the three coals studied.

It should be emphasized that the test matrices for the fixed volume batch tests were designed to determine the significant operating parameters and not to provide optimum separations and/or yield. While the yields and 
separations from the fixed volume batch tests were far from the opt 1 mum values, these tests met their goal of providing guidelines for the operation of the Research Development Unit and the Continuous Research Unit.

Table 3.1.3-5

Extent of Influence of Operating Variables

on Heating Value Recovery and Ash Reduction

Confidence Levels (\%)

\begin{tabular}{|l|c|c|c|c|c|c|}
\hline \multirow{2}{*}{ Coa1 } & \multicolumn{2}{|c|}{ Heating Value Recovery } & \multicolumn{3}{c|}{ Ash Reduction } \\
\cline { 2 - 7 } & $\begin{array}{c}\text { Particle } \\
\text { Size }\end{array}$ & $\begin{array}{c}\text { Slurry } \\
\text { Conc. }\end{array}$ & $\begin{array}{c}\mathrm{CO}_{2} \\
\text { Flowrate }\end{array}$ & $\begin{array}{c}\text { Particle } \\
\text { Size }\end{array}$ & $\begin{array}{c}\text { Slurry } \\
\text { Conc. }\end{array}$ & $\begin{array}{c}\mathrm{CO}_{2} \\
\text { Flowrate }\end{array}$ \\
\hline \hline $\begin{array}{l}\text { Pittsburgh- } \\
\text { Bucceton } \\
\text { (\#4) }\end{array}$ & $80-90$ & $>99$ & $<75$ & $<75$ & $90-95$ & $<75$ \\
$\begin{array}{l}\text { Middle } \\
\text { Kittanning } \\
(\# 6)\end{array}$ & $>99$ & $75-80$ & $<75$ & $<75$ & $<75$ & $<75$ \\
$\begin{array}{l}\text { I11inois } \\
\text { No, 6 } \\
(\# 7)\end{array}$ & $>99$ & $<75$ & $<75$ & $80-90$ & $<75$ & $<75$ \\
\hline
\end{tabular}

\subsection{Variable Volume Batch Tests}

A comprehensive series of tests were carried out in the variable volume batch mode using the Research Development Unit (RDU). In addition to the experiments specified in the project proposal, tests were also conducted to study the effects of chemical reagents, two-step cleaning and two-stage cleaning operations on process performance. In two-step cleaning, the product from a single-stage system is recycled through the column. Twostage cleaning is accomplished in a single pass through the column which has two mixing/agglomeration stages. Excellent results for ash and pyrite 
rejection were achieved at high heating value recoveries. The clean coal product leaves with liquid $\mathrm{CO}_{2}$, while the refuse remains in the separation column. The slurry volume in the column varies with time.

\subsubsection{Equipment}

A schematic diagram of the Research Development Unit is shown in Figure 3.2.1-1. The photograph of the experimental unit is shown in Figure 3.2.1-2. The main component in the RDU is the 4-inch separation column with a height of $0.76 \mathrm{~m}(2.5 \mathrm{ft})$. The volume of the column is about $0.0065 \mathrm{~m}^{3}$ (6.5 liters). The pressure, temperature, and flowrate are monitored from an instrument panel adjacent to the apparatus. The separation column has an impeller shaft passing through it and the speed of agitation can be as high as $314 \mathrm{rad} / \mathrm{s}$ ( $3000 \mathrm{rpm}$ ). A spiral plate disperser at the bottom of the cell provides for better dispersion of the liquid $\mathrm{CO}_{2}$ droplets. The unit is also equipped with three high pressure vessels which serve as the sample collectors for the clean coal-liquid $\mathrm{CO}_{2}$ slurry exiting from the top of the separation column. Refuse is collected in a sampling port located at the bottom of the separation column.

\subsubsection{Procedure}

A slurry of about $0.0032 \mathrm{~m}^{3}(3.2$ liters $)$ of coal and water was prepared and mixed well for complete wetting of the coal particles. The slurry concentration was maintained at about $5 \mathrm{wt} \%$ solids. The slurry was then manually introduced into the separation column of the RDU. Liquid $\mathrm{CO}_{2}$ was injected into the column until it completely saturated the slurry. The mixture was preconditioned for a desired time period described as "premixing time", with a layer of liquid $\mathrm{CO}_{2}$ present above the interface at an agitation speed in the range of 157-210 $\mathrm{rad} / \mathrm{s}(1500-2000 \mathrm{rpm})$. Liquid $\mathrm{CO}_{2}$ was injected from the bottom of the column at the desired flowrate through the disperser. The clean coal 


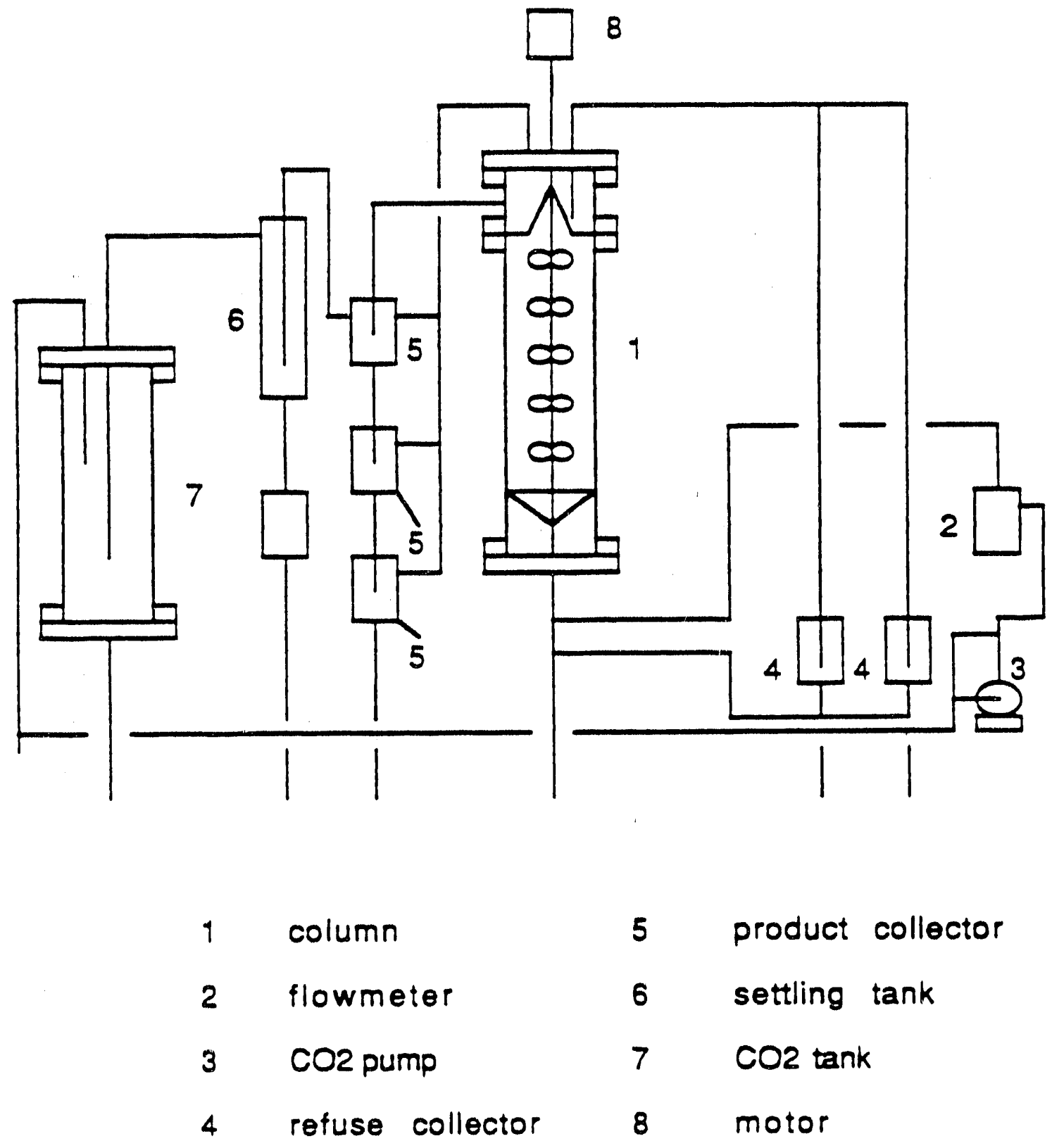

Figure 3.2.1-1. Variable Volume Batch Unit 


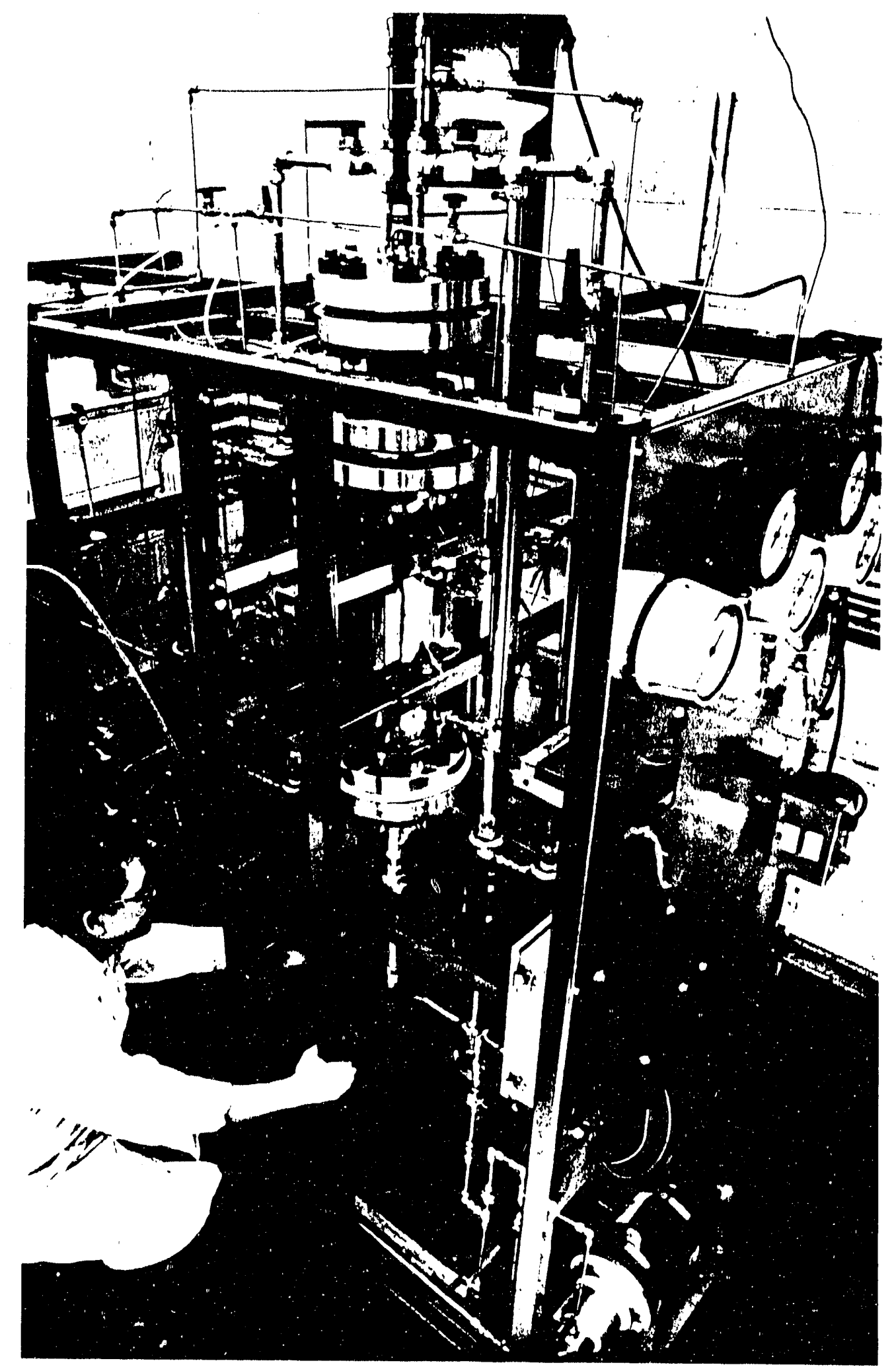

Figure 3.2.1-2. Photograph of the Research Development Unit (RDU) 
was carried up to the top to an overflow cone and collected continuousiy in the product sampler, where the liquid $\mathrm{CO}_{2}$ left the system through a back pressure valve. Refuse remained in the separation column and was removed to the refuse sampler at the termination of each test.

\subsubsection{Results and Discussion}

Eight test coals listed in Table 3.0-1 were examined in RDU tests. Experiments using the RDU were performed over a wide range of operating condi tions. These are listed in Table 3.2.3-1.

Table 3.2.3-1

Range of Process Operating Conditions in RDU Experiments

\begin{tabular}{|c|c|}
\hline Temperature, $\mathrm{K}$ & $293-300\left(70-80^{\circ} \mathrm{F}\right)$ \\
\hline $\begin{array}{l}\text { Slurry Concentration, } \\
\text { Wt\% solid }\end{array}$ & 5 \\
\hline $\begin{array}{l}\text { Particle Size, microns } \\
\text { (Surface-volume mean dia) }\end{array}$ & $10-100$ \\
\hline Pressure, $\mathrm{MPa}$ & $5.5-6.5(800-950 \mathrm{psig})$ \\
\hline $\begin{array}{l}\text { Contact Time for } \\
\text { Liquid } \mathrm{CO}_{2}, \mathrm{~s}\end{array}$ & $300-1200$ \\
\hline $\begin{array}{l}\text { Liquid } \mathrm{CO}_{2} \text { Flowrate, } \\
\mathrm{m}^{3} / \mathrm{s} \times 10^{-}-6\end{array}$ & $6.6-16.6(400-1000 \mathrm{ml} / \mathrm{min})$ \\
\hline Agitation Speed, rad/s & $63-177(600-1700 \mathrm{rpm})$ \\
\hline Premixing Time, s & $30-1800$ \\
\hline Premixing Speed, rad/s & $157-230(1500-2200 \mathrm{rpm})$ \\
\hline
\end{tabular}

The results of experiments conducted in variable volume batch mode in the RDU represent a remarkable improvement over those obtained in the BRU (presented earlier in section 3.1.3). Experiments with Upper Freeport 
coal (coal \#1 in Table 3.0-1) were carried out at a slurry concentration of $5 \%$ while maintaining the nominal particle size constant at -74 microns for a contact time of $900 \mathrm{~s}$. Table 3.2.3-2 shows that excellent ash and pyrite rejection could be achieved with high heating value recoveries. When the mixing speed was $63 \mathrm{rad} / \mathrm{s}(600 \mathrm{rpm})$, at a liquid $\mathrm{CO}_{2}$ flow rate of $6.6 \times 10-6 \mathrm{~m}^{3} / \mathrm{s}(400 \mathrm{ml} / \mathrm{min})$, it was possible to recover nearly $70 \%$ of the original heating value. The ash and pyritic sulfur rejections were greater than $90 \%$. When the mixing speed was altered to $104 \mathrm{rad} / \mathrm{s}(1000 \mathrm{rpm})$, the heating value recovery improved further to $82 \%$ with only a marginal decrease in ash/pyrite rejection. The longer column in the RDU appears to be more favorable for ash/pyrite rejection than the BRU. The agglomerates with entrapped ash material can be broken up to release the mineral matter before being reformed and removed as product from the column.

Table 3.2.3-2

RDU Experiments with Upper Freeport Coal

\begin{tabular}{|c|c|c|c|c|c|}
\hline $\begin{array}{c}\text { Mixing } \\
\text { Speed } \\
(\mathrm{rad} / \mathrm{s})\end{array}$ & $\begin{array}{c}\text { Liquid } \mathrm{CO}_{2} \\
\text { Flowrate } \\
\times \mathrm{m}^{3} \\
\times 10-6\end{array}$ & $\begin{array}{c}\text { Heating Value } \\
\text { Recovery } \\
(\%)\end{array}$ & $\begin{array}{c}\text { Product } \\
\text { Ash } \\
(\%)\end{array}$ & $\begin{array}{c}\text { Ash } \\
\text { Rejection } \\
(\%)\end{array}$ & $\begin{array}{c}\text { Pyrite } \\
\text { Rejection } \\
(\%)\end{array}$ \\
\hline \hline 63 & 6.6 & 69.1 & 2.1 & 95.3 & 95.1 \\
138 & 6.6 & 86.6 & 4.5 & 87.5 & 85.4 \\
177 & 6.6 & 88.5 & 9.5 & 71.3 & 78.8 \\
104 & 9.1 & 83.6 & 4.0 & 89.3 & 90.6 \\
\hline
\end{tabular}

Figure 3.2.3-1 shows the variation in the rejection of pyritic sulfur as a function of impeller speed for Upper Freeport coal in the RDU. The results suggest that lower impeller speeds provide more favorable conditions for rejection of pyritic sulfur. While higher stirring speeds contribute to better dispersion of the $\mathrm{CO}_{2}$ droplets and improved contact with the 


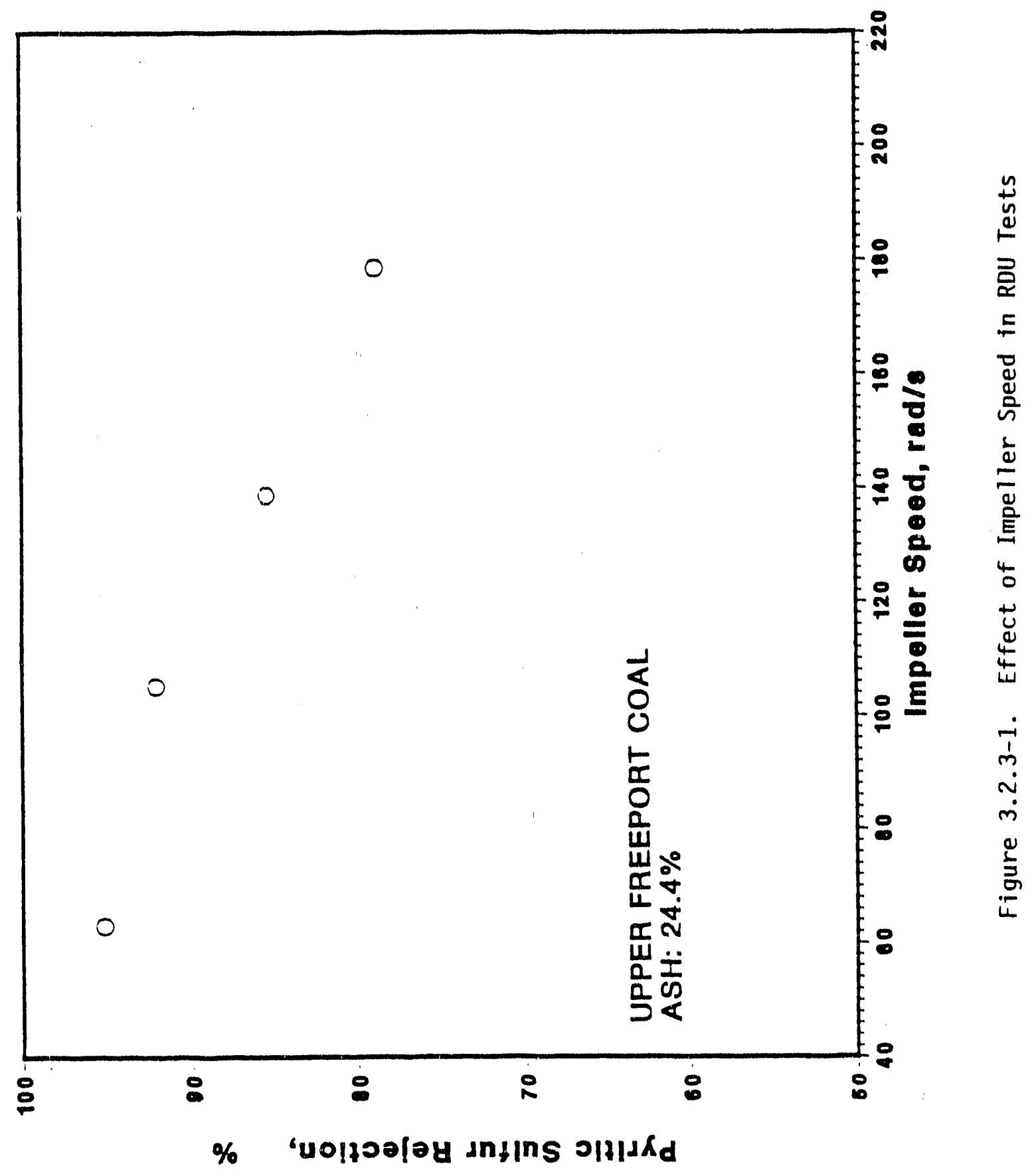


coal particles (thereby increasing the heating value recovery), the entrapment of pyritic sulfur particles in the product is also increased. It should, however, be noted that even when the impeller speed was increased to $177 \mathrm{rad} / \mathrm{s}$ (1700 $\mathrm{rpm})$, the pyritic sulfur rejection was close to $80 \%$ while the heating value recovery was nearly $90 \%$.

Figure 3.2.3-2 depicts the variation of the rejection of pyritic sulfur as a function of flowrate for the same Upper Freeport coal in the RDU. The trend is similar to that shown in Figure 3.2.3-1 for variation in impeller speed. The flowrate of liquid $\mathrm{CO}_{2}$ should be sufficiently high to wet the coal particles and act as a bridging liquid between clean coal particles. Excessively high flow rates cause entrapment and subsequently entrainment of the finely ground ash material (including pyrite) in the clean coal phase, with a concomitant increase in the ash and pyritic sulfur content of the product.

The effect of premixing on the cleaning characteristics of Illinois No. 6 coal, as well as Upper Freeport coal, was also investigated in the variable volume mode in the RDU. A relatively low ash Illinois No. 6 coal (coal \#8 in Table 3.0-1) was utilized in these experiments while similar studies were conducted with the sample of Upper Freeport coal (coal \#2 in Table 3.0-1). The flowrate of liquid $\mathrm{CO}_{2}$ was maintained at $6.6 \times$ 10-6 $\mathrm{m}^{3} / \mathrm{s}(400 \mathrm{ml} / \mathrm{min})$. The particle size of the two coals was nominally -74 microns. The premixing speed was maintained at $215 \mathrm{rad} / \mathrm{s}$ $(2050 \mathrm{rpm})$ and a slurry concentration of $6.3 \%$ was employed in these experiments.

The results of varying the premixing time are summarized in Table 3.2.3-3. For the Upper Freeport coal, a final product ash content of $3.3 \%$ was obtained at a heating value recovery of $78 \%$ without any premixing in the system. When the premixing operation was performed for $600 \mathrm{~s}$, the heating value recovery increased to $84 \%$ with a concomitant increase in ash content. Howwever, a perceptible improvement in ash reduction was accom- 


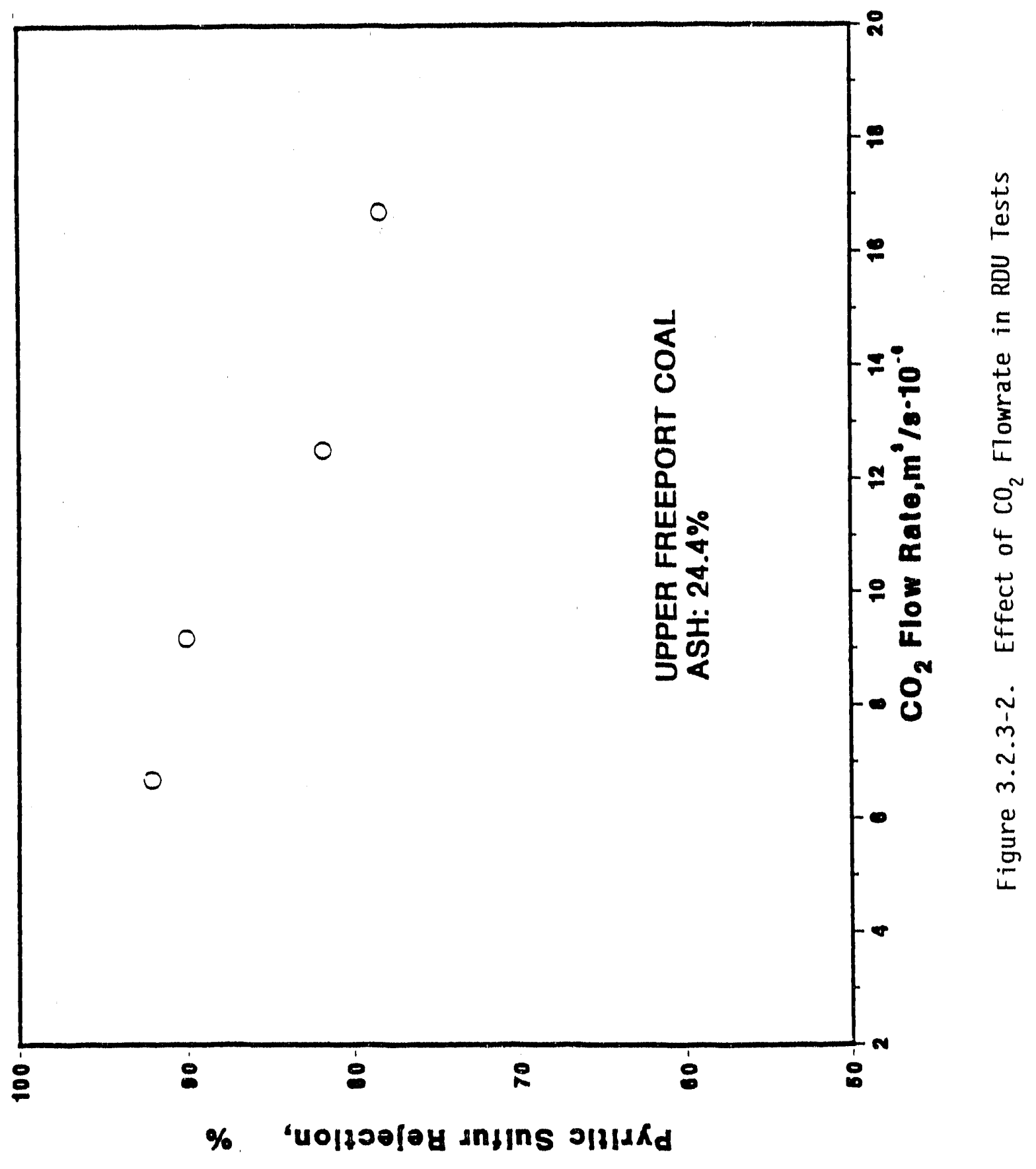


plished by premixing for only $30 \mathrm{~s}$ while using a low liquid $\mathrm{CO}_{2}$ /slurry ratio $(0.16)$. The liquid $\mathrm{CO}_{2} /$ coal ratio that was usually maintained in the period promotes the formation of agglomerates of liquid $\mathrm{CO}_{2} /$ coal particles, thereby increasing the recovery. However, entrapment of ash in the agglomerates could decrease selectivity for clean coal. In the case of the Illinots No, 6 coal, Table 3.2.3-3 shows that the heating value recovery again increased for the longer premixing time with little change in ash rejection. These results demonstrate that premixing time is an important parameter in the process, and it is necessary to determine the optimum premixing pertod for each coal to achieve desired results. Generally, the hydrophobic coals (such as Upper Freeport coal) require less premixing time than the hydrophilic coals (such as Illinois No. 6 coal).

Table 3.2.3-3

Effect of Premixing Time in RDU Operation

Ash in Upper Freeport Coal: $22.7 \%$

Ash in Illinoits No. 6 Coal: $12.6 \%$

\begin{tabular}{|c|c|c|c|c|c|}
\hline Coa1 & $\begin{array}{c}\text { Premixing } \\
\text { Time } \\
(\mathrm{s})\end{array}$ & $\begin{array}{c}\text { Heating Value } \\
\text { Recovery } \\
(\%)\end{array}$ & $\begin{array}{c}\text { Product } \\
\text { Ash } \\
(\%)\end{array}$ & $\begin{array}{c}\text { Ash } \\
\text { Rejection } \\
(\%)\end{array}$ & $\begin{array}{c}\text { Pyrite } \\
\text { Rejection } \\
(\%)\end{array}$ \\
\hline \hline Upper Freeport & 0 & 78.4 & 3.3 & 90.8 & 82.8 \\
Upper Freeport & 30 & 78.3 & 2.6 & 92.7 & 85.0 \\
Upper Freeport & 600 & 84.5 & 5.7 & 82.5 & 74.4 \\
I11 inois No.6 & 180 & 62.8 & 7.7 & 53.7 & 59.9 \\
I11 inois No.6 & 600 & 70.5 & 7.4 & 50.2 & 56.8 \\
\hline
\end{tabular}

Figure 3.2.3-3 shows the change in heating value recovery for the low ash Illinois No. 6 coal and the Middle Kittanning coal (coal \#8 and \#6 in Table 3.0-1, respectively) as the average particle size is increased from 20 to 75 microns. In these experiments, the coal slurry in water (concen- 


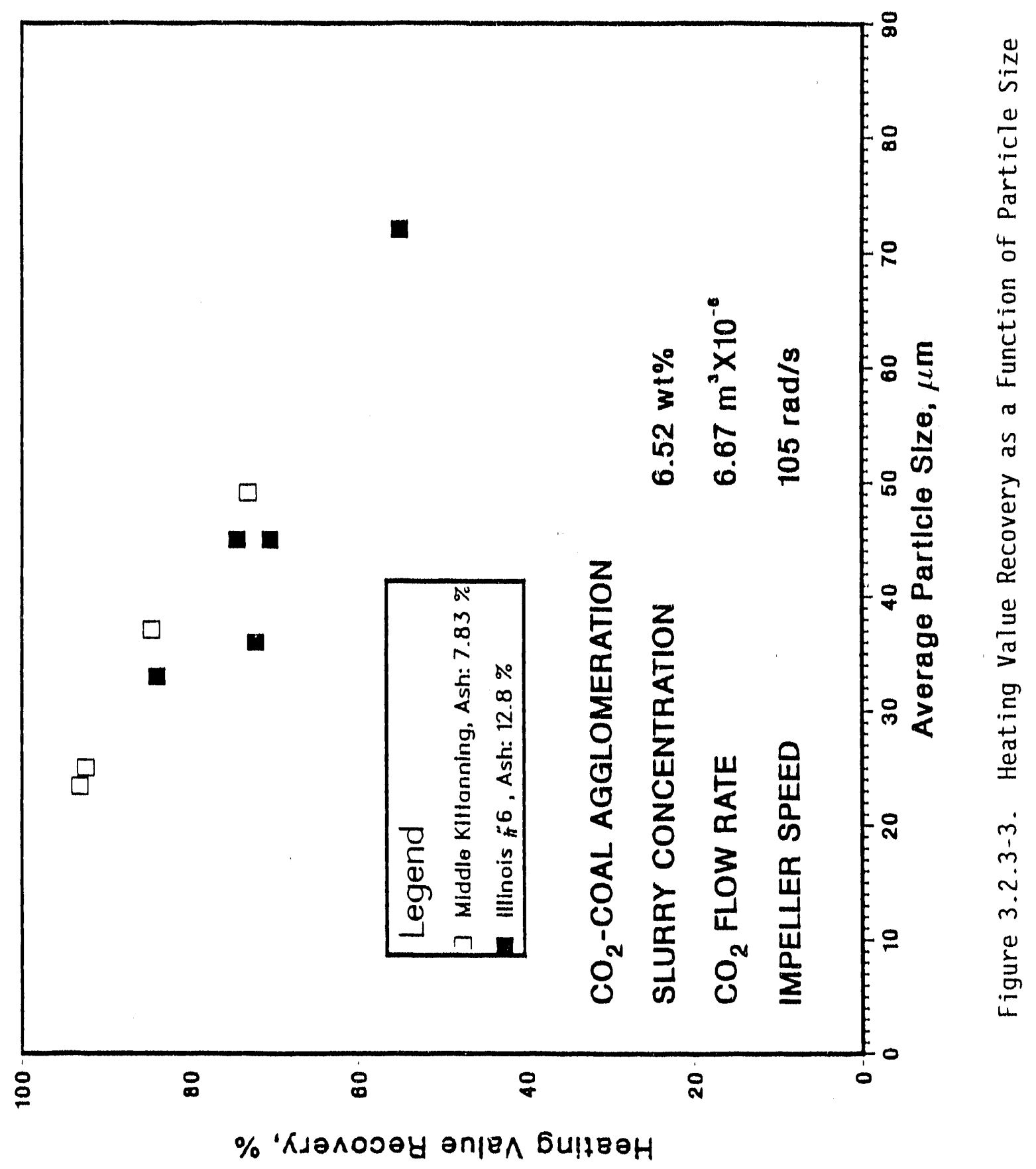


tration: 6.5\%) was premixed for $900 \mathrm{~s}$ with liquid $\mathrm{CO}_{2}$ prtor to performing the experiment. During the experiment, the flowrate of liquid $\mathrm{CO}_{2}$ was fixed at $6.6 \times 10.6 \mathrm{~m}^{3} / \mathrm{s} \quad(400 \mathrm{ml} / \mathrm{min}) ;$ and the agltation speed was $104 \mathrm{rad} / \mathrm{s}$ (1000 rpm).

Figure 3.2.3-3 shows that grinding the two coals to particle sizes below 40 microns is benefictal to achieving high heating value recoveries. A sharp decrease in the recovery is registered for an average particle size larger than 70 microns. The separation characteristics are plotted in Figure 3.2.3-4 for the same experimental conditions for the Illinots No, 6 coa1. It can be observed from Figure 3.2.3-4 that the rejection of ash and pyritic sulfur is increased only at the larger particle sizes (exceeding 70 microns). This phenomena is unique for the coal- $\mathrm{CO}_{2}$ system. Hence, there appears to be a trade-off between the heating value recovery and the ash and pyrite rejection. Fine grinding the particles down to smaller particle sizes appears to enhance the heating value recovery while a substantial portion of the finely ground mineral matter is entrapped in the clean coal-1 lquid $\mathrm{CO}_{2}$ agglomerate structure. This conclusion is similar to that obtained in fixed volume batich tests, which have been discussed earlifar in section 3.1. A two-stage separator, discussed later in this section, was designed to eliminate the trapping of ash material by breaking the agglomerates from the first stage and reforming them in the second stage.

Similar separation characteristics were observed for the Middle Kittanning coal as a function of particle size, as shown in Figure 3.2.3-5. An improvement in ash and pyrite rejection is achieved as the particle size is increased from 20 to 50 microns. It can also be observed from Flgure 3.2.3-3 that the heating vaiue recovery decreased by about 20 percentage points as the particle size increased, in this range of particle size.

\subsubsection{Effect of Chemical Reagents}

The effect of conditioning the various coals with selective chemical 


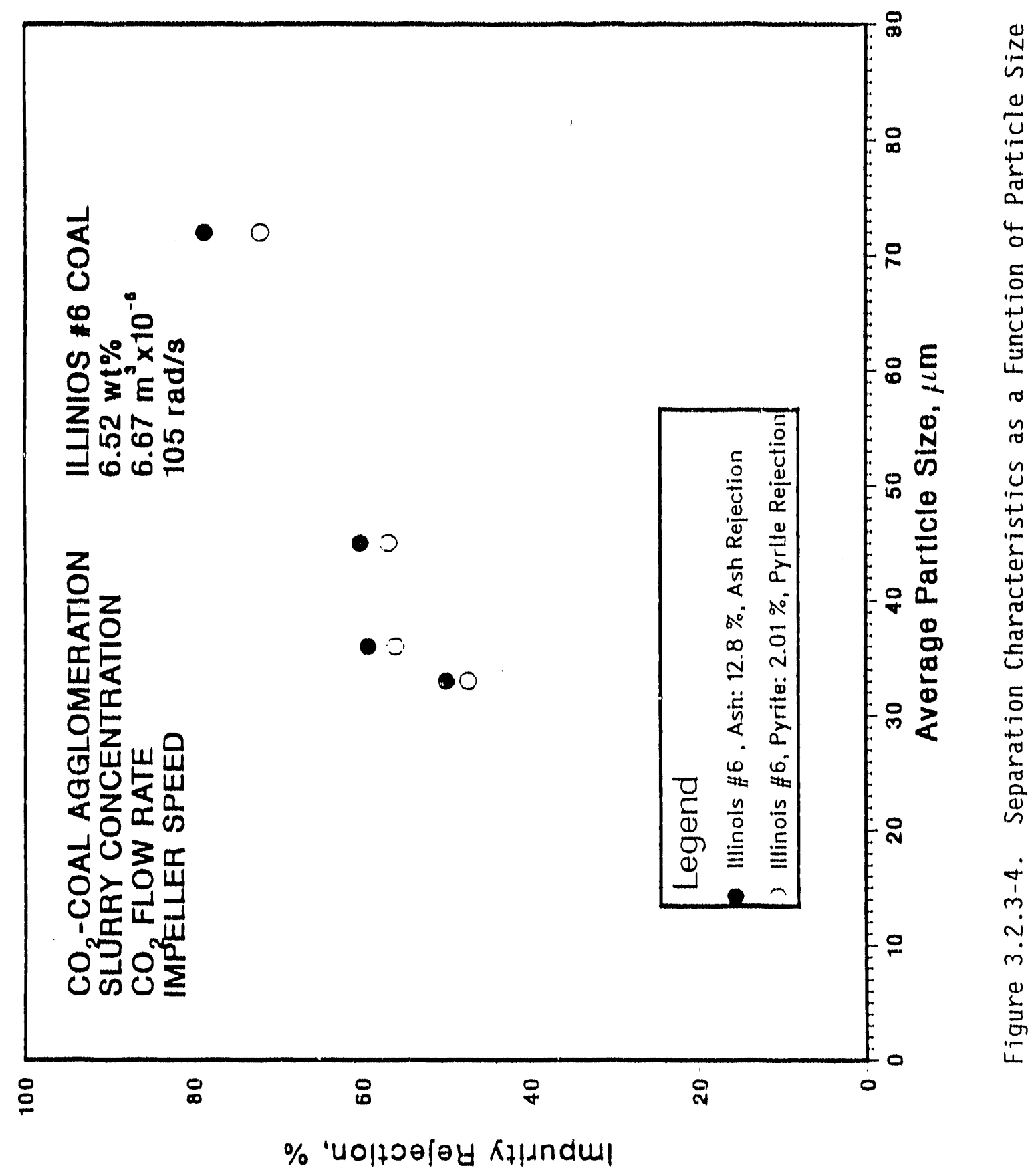




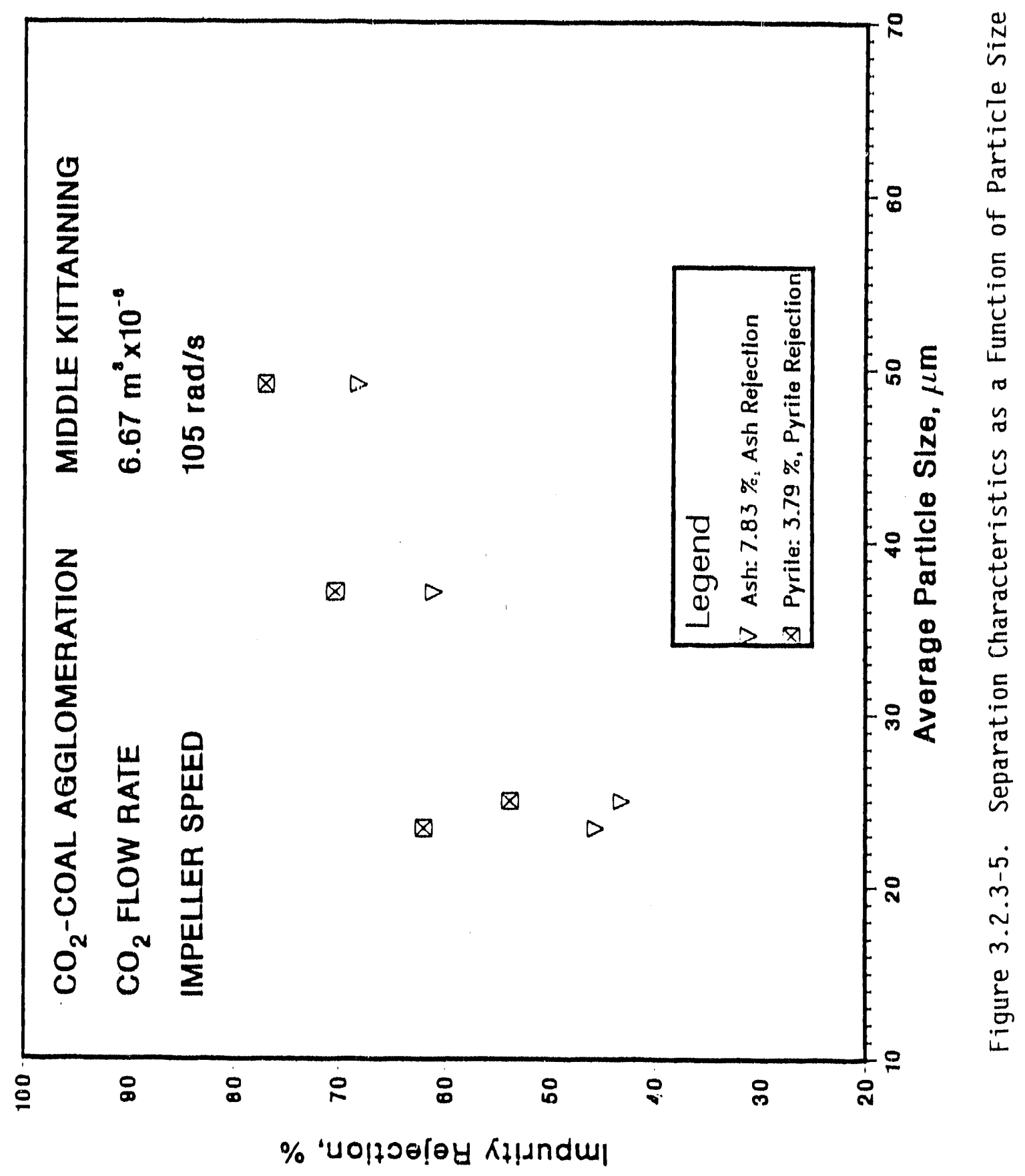


reagents was also investigated in the varlable volume batch studies. These studies were in addition to those spectfied in the project proposal and were primarlly carried out to seek improved process performance.

The effect of fine grinding in the presence of different concentrations (in solution) of the dispersant SHMP (Sodium Hexametaphosphate) is shown in Table 3.2.3-4. For the sake of comparison, the results obtained by grinding without the reagent are included in Table 3.2.3-4. In the case of Upper Freeport coal (coal \#1), the dispersant did not adversely affect the heating value recovery; but for the Illinois No. 6 coal (coal \#8), a substantial drop in the recovery was observed for the sample having an average particle size of 36 microns. This suggests that the reagent was not effective. Furthermore, a substantial decrease in the ash rejection potential was registered for both the coals when the particles were ground

Table 3.2.3-4

Effect of Particle Size and Dispersant in RDU Operation Dispersant: Sodium Hexametaphosphate

\begin{tabular}{|c|c|c|c|c|}
\hline Coal & $\begin{array}{c}\text { Dispersant } \\
\text { Conc } \\
\text { (ppm) }\end{array}$ & $\begin{array}{c}\text { Particlo } \\
\text { Size } \\
\text { (microns) }\end{array}$ & $\begin{array}{c}\text { Heating } \\
\text { Value } \\
\text { Recovery } \\
(\%)\end{array}$ & $\begin{array}{c}\text { Ash } \\
\text { Rejection } \\
(\%)\end{array}$ \\
\hline \hline Upper Freeport & 0 & 30 & 79.5 & 86.9 \\
& 30 & 30 & 81.0 & 86.3 \\
& 30 & 30 & 82.4 & 88.6 \\
I11 inois No.6 & 0 & 36 & 77.0 & 38.6 \\
& 30 & 36 & 54.5 & 78.0 \\
& 80 & 36 & 41.5 & 77.7 \\
& 30 & 18 & 82.6 & 26.9 \\
\hline
\end{tabular}


finer than 20 microns. Another interesting observation was that the heating value recovery was significantly enhanced for the finer size Illinois No. 6 coal. This latter finding indicates that the fine ash material was being entrapped in the clean coal agglomerates. It was visually observed that the agglomerates appear to be of a larger size when the feed material contained very fine particles. It can be concluded that grinding the particles to very fine sizes is detrimental to the removal of ash from the product in this type of operation. It can also be inferred that the dispersant SHMP did not yield desirable results in terms of improvements in heating value recovery or ash rejection.

Experiments were also conducted with 1-0ctanol. The results are shown in Table 3.2.3-5. In the case of the Upper Freeport coal (coal \#2) and the high ash Pittsburgh coal (coal \#5), it was interesting to note that the heating value recovery increased steadily with reagent dosage, indicating that 1-Octanol facilitated the attachment of the droplets of liquid $\mathrm{CO}_{2}$ to the clean coal particles. Hence, 1-0ctanoi appears to behave as a coagglomerating agent in these instances. The effect on ash rejection is not significant for these coals.

The effect of 1-Octanol on Illinois No. 6 coal (coal \#7) is also illustrated in Table 3.2.3-5. The experimental conditions were the same as those employed for the other coals. Tests were conducted with samples wet ground for $600 \mathrm{~s}$ to a weight mean diameter of 35 microns. The addition of 1-Octanol effected a marked improvement in the ash rejection.

\subsubsection{Two-Step Cleaning Experiments}

Variable volume batch two-step experiments were conducted in the RDU with the high ash Illinois No. 6 coal (coal \#7). The clean coal product from the first step was utilized as the feed during the second cleaning step. The results are presented in terms of overall heating value recovery and ash and pyrite content of the product. 
The results presented in Table 3.2.3-6 indicate that it was possible to reduce the ash content in the product to $6.9 \%$ for the extremely hydrophilic sample of Illinois No. 6 coal after two cleaning steps, while obtaining a heating value recovery exceeding $71 \%$ for the second step. The results demonstrate the effectiveness of the process for ash removal. The pyrite removal is, however, not as favorable and is likely due to the problem of liberating finely dispersed pyrite particles from the coal matrix. It should also be pointed out that the overall heating value recovery could be further improved if the refuse from the first step were subjected to a second reprocessing step.

Table 3.2.3-5

Effect of 1-Octanol on Test coals

\begin{tabular}{|c|r|c|c|c|}
\hline Coal & $\begin{array}{c}\text { Reagent } \\
\text { Conc. } \\
(\mathrm{ppm})\end{array}$ & $\begin{array}{c}\text { Heating Value } \\
\text { Recovery } \\
(\%)\end{array}$ & $\begin{array}{c}\text { Product } \\
\text { Ash } \\
(\%)\end{array}$ & $\begin{array}{c}\text { Ash } \\
\text { Rejection } \\
(\%)\end{array}$ \\
\hline \hline \multirow{3}{*}{ Pittsburgh } & 0 & 67.4 & 7.6 & 87.9 \\
& 80 & 73.6 & 6.5 & 88.5 \\
& 170 & 74.4 & 7.3 & 87.5 \\
Upper Freeport & 0 & 79.6 & 4.5 & 88.4 \\
& 30 & 80.7 & 4.5 & 88.2 \\
& 115 & 84.8 & 4.1 & 88.9 \\
& 0 & 77.6 & 9.1 & 61.9 \\
& 80 & 73.8 & 7.1 & 84.1 \\
& 155 & 80.3 & 8.2 & 79.8 \\
\hline \hline
\end{tabular}


Table 3.2.3-6

Two-Step Experiments with Illinois No. 6 Coal

Feed Ash: $26.0 \%$

\begin{tabular}{|c|c|c|c|c|}
\hline $\begin{array}{c}\text { Flowrate } \\
\left(\mathrm{m}^{3} / \mathrm{s}\right) \\
\times 10-6\end{array}$ & $\begin{array}{c}\text { Step } \\
\text { No. }\end{array}$ & $\begin{array}{c}\text { Heating Value } \\
\text { Recovery } \\
(\%)\end{array}$ & $\begin{array}{c}\text { Product } \\
\text { Ash } \\
(\%)\end{array}$ & $\begin{array}{c}\text { Product } \\
\text { Pyrite } \\
(\%)\end{array}$ \\
\hline \hline 6.6 & 1 & 79.8 & 16.0 & 2.0 \\
5.3 & 2 & 71.1 & 6.9 & 1.5 \\
5.3 & 1 & 71.3 & 18.6 & 2.2 \\
$6.6 *$ & 2 & 46.2 & 6.3 & 1.4 \\
\hline
\end{tabular}

* Sample deslimed with hot water.

To facilitate comparison, the results of experiments conducted with Middle Kittanning coal are presented in Table 3.2.3-7. It can be observed that a substantially improved removal of ash was achieved while maintaining a high heating value recovery. The pyrite removal after the two-step treatment is excellent. While the two-step treatment was necessary to achieve desirable results for Middle Kittanning coal, it was possible to obtain good separation of mineral matter and coal with the single step treatment for the Upper Freeport coal, as discussed earlier (Table 3.2.3-2). These results are in agreement with the conclusions drawn earlier from the contact angle measurements on these coals (Table $3.0-2)$. Since the Illinois No. 6 coal exhibited a hydrophilic nature even in the presence of liquid $\mathrm{CO}_{2}$, it was difficult to achieve high ash/pyrite rejection with good heating value recovery even after the two-step treatment. The liberation characteristics of Illinois No. 6 coal could also be affected by the distribution of mineral matter in the coal. 
Table 3.2.3-7

Two-Step Experiments with Middle Kittanning Coal

Feed Ash: $7.8 \%$

\begin{tabular}{|c|c|c|c|c|}
\hline $\begin{array}{c}\text { Flowrate } \\
\left(\mathrm{m}^{3} / \mathrm{s}\right) \\
\times 10-6\end{array}$ & $\begin{array}{c}\text { Step } \\
\text { No. }\end{array}$ & $\begin{array}{c}\text { Heating Value } \\
\text { Recovery } \\
(\%)\end{array}$ & $\begin{array}{c}\text { Product } \\
\text { Ash } \\
(\%)\end{array}$ & $\begin{array}{c}\text { Product } \\
\text { Pyrite } \\
(\%)\end{array}$ \\
\hline \hline 6.6 & 1 & 88.8 & 3.9 & 1.4 \\
6.6 & 2 & 77.1 & 2.0 & 0.7 \\
$6.6 *$ & 1 & 84.5 & 4.6 & 1.7 \\
$6.6 *$ & 2 & 72.3 & 1.7 & 0.7 \\
\hline
\end{tabular}

* Sample deslimed with hot water.

\subsubsection{Two-Stage Cleaning Experiments}

In order to seek a further improvement in process performance, a two-stage treatment unit for the RDU was designed and fabricated. This unit is shown in Figure 3.2.3-6. The same feed sample was utilized in this configuration. Two cylindrical draft tubes of 3 inch I.D. Were installed inside the 4-inch separation column of the RDU with a conical section on top. A vortex inducing plate was attached to the top of each draft tube, and the impeller shaft passed through the two draft tubes. In this arrangement, the clean coal and refuse material were expected to be ejected tangentially from the vortex plates after being subjected to vigorous agitation of at least $104 \mathrm{rad} / \mathrm{s}(1000 \mathrm{rpm})$. The denser refuse material was expected to sink to the bottom after collision with the wall of the separation column. The lighter clean coal agglomerates were collected at the top after overflowing from the conical section.

Initial results for the two-stage cleaning device are presented in Figures 3.2.3-7 and Figure 3.2.3-8 for Upper Freeport coal (coal \#3). 


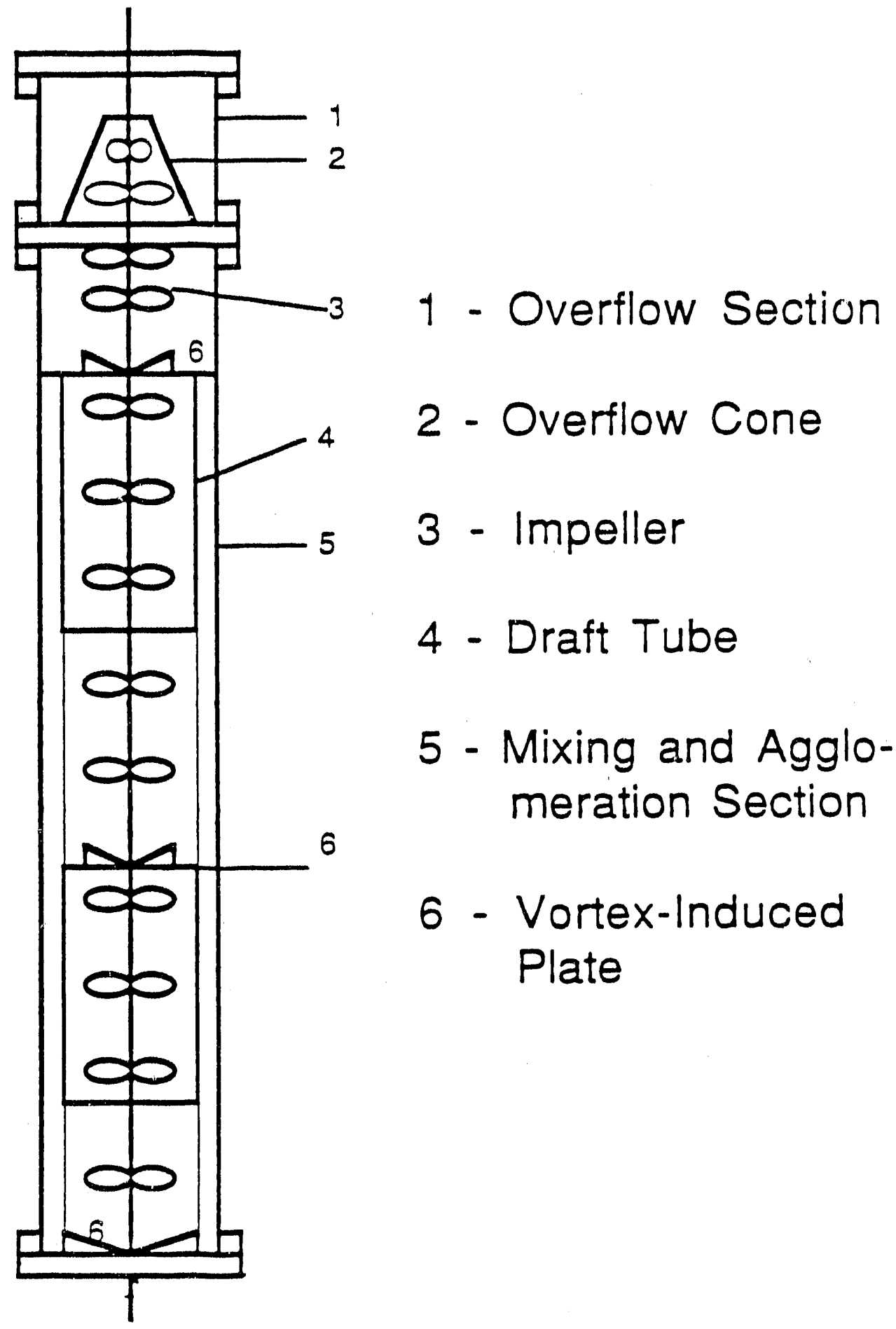

Figure 3.2.3-6. Multistage Separation Column 


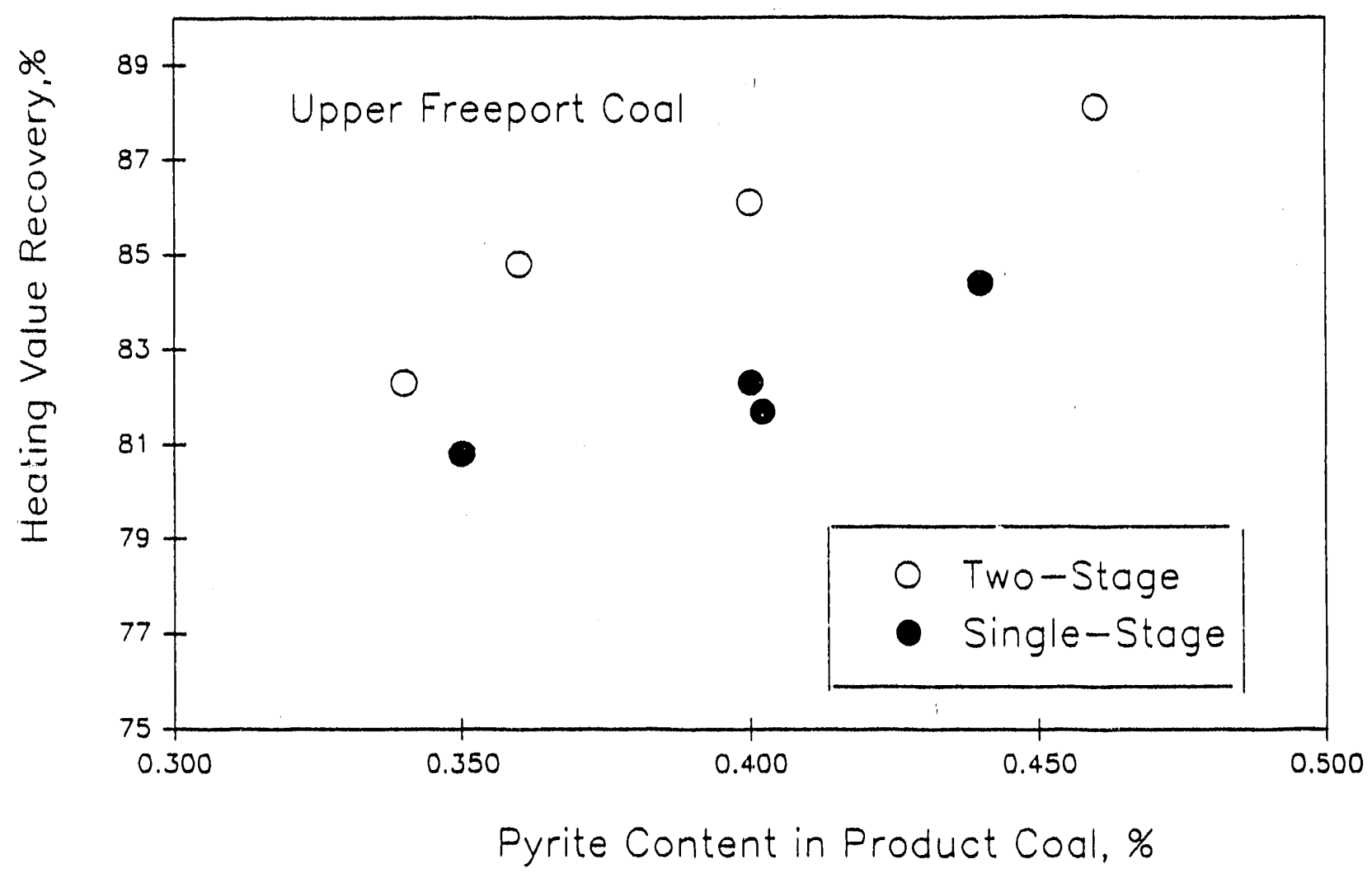

Figure 3.2.3-7. Single-Stage Versus Two-Stage Performance 


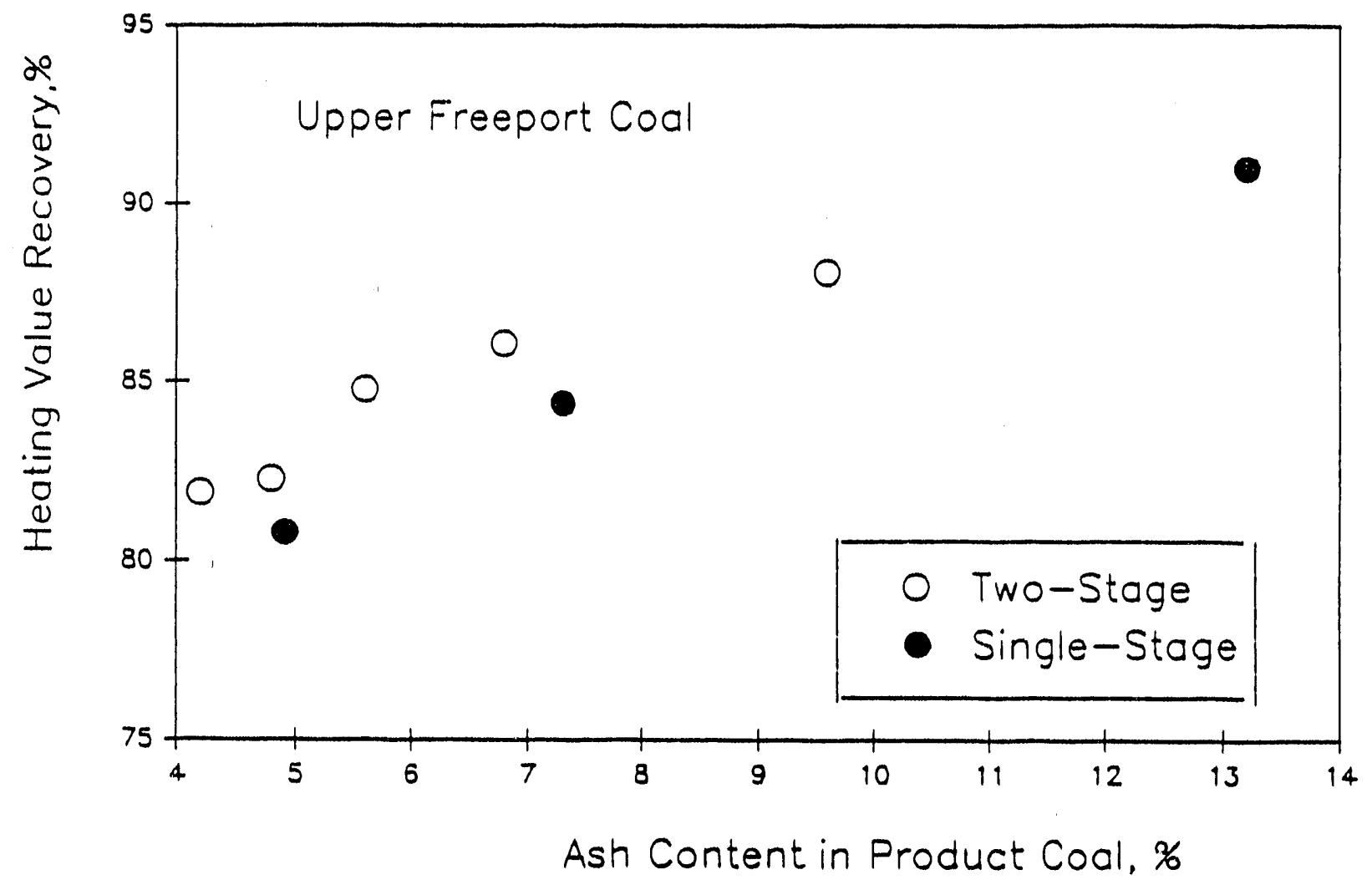

Figure 3.2.3-8. Single-Stage Versus Two-Stage Performance 
Figure 3.2.3-7 compares the pyrite content in the product for Upper Freeport coal cleaned in two stages with that cleaned in a single stage. The product pyrite content is significantly lower at equivalent heating value recoveries for the two-stage processing tests. For instance, at $85 \%$ heating value recovery, the clean coal pyrite content is $0.47 \mathrm{wt} \%$ for the single stage and $0.38 \mathrm{wt} \%$ for two stages. Thts corresponds to an increase in pyrite reduction from $58 \%$ to $66 \%$, or an improvement of $13.7 \%$ for two-stage cleaning. From figure 3.2.3-8, it is clear that the ash content in the product also decreases after two-stage treatment. This suggests that agglomerates from the first stage were being broken up to release the entrapped mineral matter before the agglomerates were reformed in the second stage. The data for two-stage treatment with Pittsburgh and llinois coals also appears very promising. There is a substantial improvement in ash and pyrite reductions after incorporating the second stage.

Additional stages can be easily and economically incorporated into the separation column for the Research Development Unit as well as the Continucus Research Unit, since the stage hardware is simple and does not affect the separator column size. Further testing with multistage devices is proposed to be conducted in the next phase of the project. Finer grinding of particles is also proposed, since the heating value recovery has been shown to increase at smaller particle sizes (as discussed earlier). The negative impact of smaller particles causing an increase in the product ash content, due to entrapment in the larger agglomerates, will be eliminated through the multistage separator. In the case of hydrophilic coals such as Illinois No. 6 coal, preconditioning with 1-Octanol may be coupled with multistage treatment to achieve the desired results.

\subsubsection{Moisture Content of Clean Coal Product}

An outstanding feature of the LICADO process is the very dry clean coal product. Figure 3.2.3-9 shows the variation of moisture content of the clean coal product as a function of impeller speed for coal \#1. It can be 


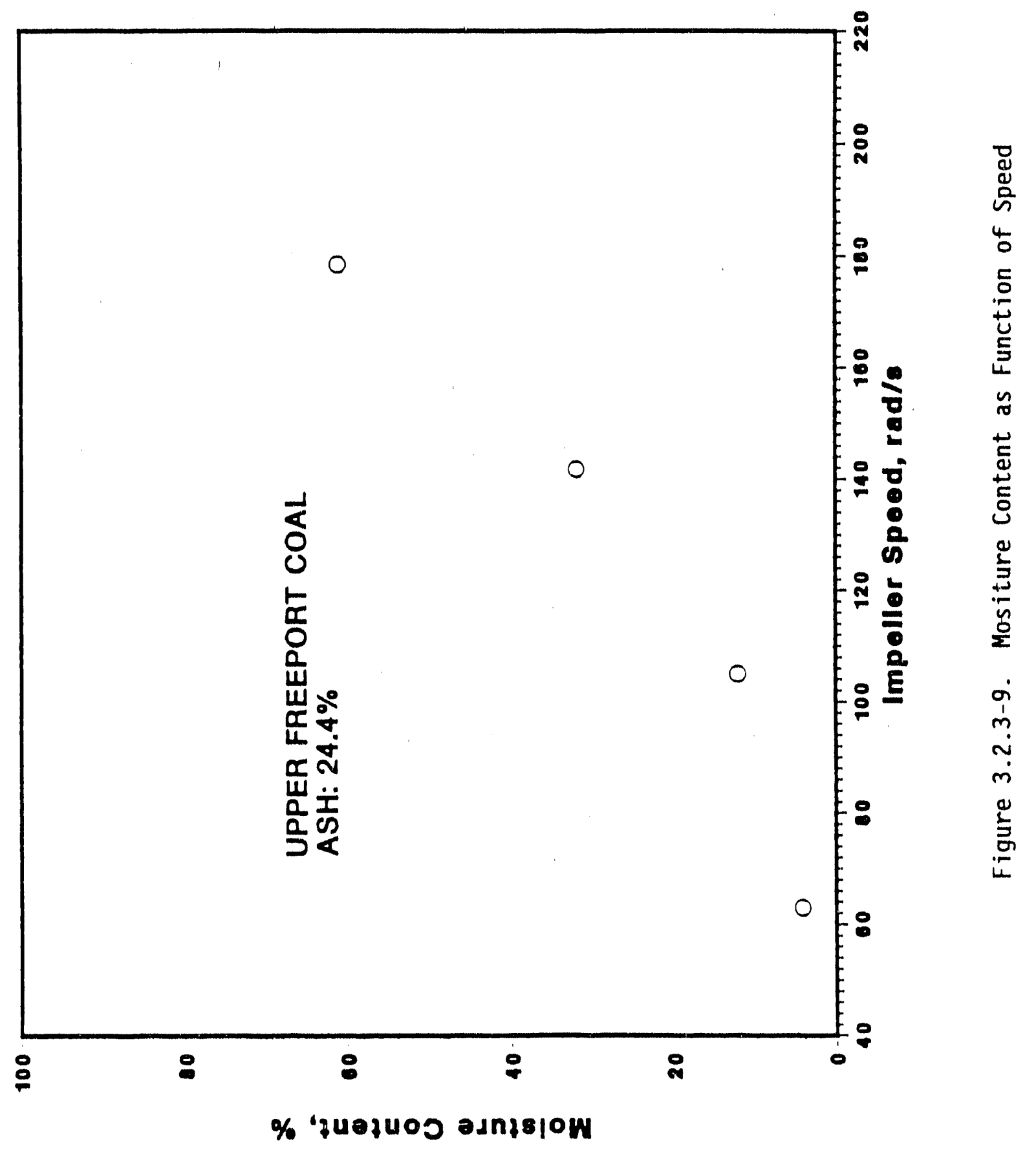


observed that motsture contents as low as $5 \%$ were obtained at lower impeller speeds. The moisture content is less than $15 \%$ at a mixing speed of $104 \mathrm{rad} / \mathrm{s}(1000 \mathrm{rpm})$. Higher agltation speeds resulted in increased motsture in the product. Table 3.2.3-2 shows that at an impeller speed of $104 \mathrm{rad} / \mathrm{s}$, the heating value recovery was $82 \%$, while the ash and pyrite rejections were in the $90 \%$ range. It appears that $104 \mathrm{rad} / \mathrm{s}$ is the destred mixing speed for coal \#1. There is also direct correspondence between the product moisture content and ash content. The ash content in the product increases with the moisture content (at the higher impeller speeds). Similar results were obtained in the operation of the Continuous Research Unit, as discussed in section 4.3.

\subsubsection{Summary of Vartable Volume Tests}

In all cases, the results from experiments conducted in the varlable volume batch mode in the RDU have demonstrated that high ash and pyrite rejections were possible at excellent heating value recoveries. A summary of the results at $85 \%$ heating value recovery for four coals is given below in Table 3.2.4-1.

Table 3.2.4-1

Pyrite and Ash Content at $85 \%$ Heating Value Recovery

\begin{tabular}{|l|c|c|c|c|}
\hline Coa1 & $\begin{array}{c}\text { Pyrite in } \\
\text { Feed } \\
\text { Wt\% }\end{array}$ & $\begin{array}{c}\text { Pyrite in } \\
\text { Product } \\
\text { Wt\% }\end{array}$ & $\begin{array}{c}\text { Pyrite } \\
\text { Rejection } \\
\%\end{array}$ & $\begin{array}{c}\text { Ash } \\
\text { in Product } \\
\%\end{array}$ \\
\hline \hline Upper Freeport & 1.1 & 0.17 & 89.5 & 5.0 \\
Middle Kittanning & 4.0 & 0.70 & 85.8 & 3.8 \\
Pittsburgh & 2.4 & 0.35 & 88.5 & 5.0 \\
I1linois No.6 & 2.7 & 1.10 & 72.7 & 6.1 \\
\hline
\end{tabular}

It can be concluded that high pyrite and ash reductions were demonstrated at high heating value recoveries for most of the coals investigated by the 
LICADO process. As stated earlier, future tests wlll involve use of multistage devices, fine grinding, and Judictous use of additives to further improve process performance.

\subsubsection{Compartson With Washability Data}

Washabllity data for the -74 micron (-200 mesh) particle size were obtained for four of the coals investigated in this project. These included Upper Freeport coal (coal \#2), Middle Kittanning coal (coal \#6), and high ash 111 inois No. 6 coal (coal \#7). Washabllity data were also obtalned for a low ash Upper Freeport coal (coal \#3).

A plot of heating value recovery as a function of ash in the product is shown for the high ash Upper Freeport coal in Figure 3.2.5-1. Within experimental error, the proces's performance obtained with the RDU appears to match the washability curve closely for the -74 micron coal samples. The anomaly that the LICADO data appear to exceed the limits of the washability curve could be attributed to two possibilities. Firstiy, signiftcant experimental error could be introduced while conducting washability analysis for coals as fine as -74 microns. Secondly, the more 1 lkely explanation lies in the fact that the washablitty and the agglomeration process (LICADO) rely on two very different mechanisms and driving forces. The former is a gravity settling process depending on particle density. The latter depends on surface forces. Thus, the achievable separation by the LICADO process may indeed surpass the 1 imit of washability. Figure 3.2.5-2 shows the comparison if the two sets of data for the heating value recovery as a function of pyritic sulfur in the product for the high ash Upper Freeport coal. Again, outstanding results for removal of pyritic sulfur are evident. Figure 3.2.5-3 depicts similar charactertstics for product ash in the case of the low ash Upper Freeport coal. It can be concluded that excellent separation characteristics were achieved with the LICADO process at high heating value recoveries for Upper Freeport coal. 


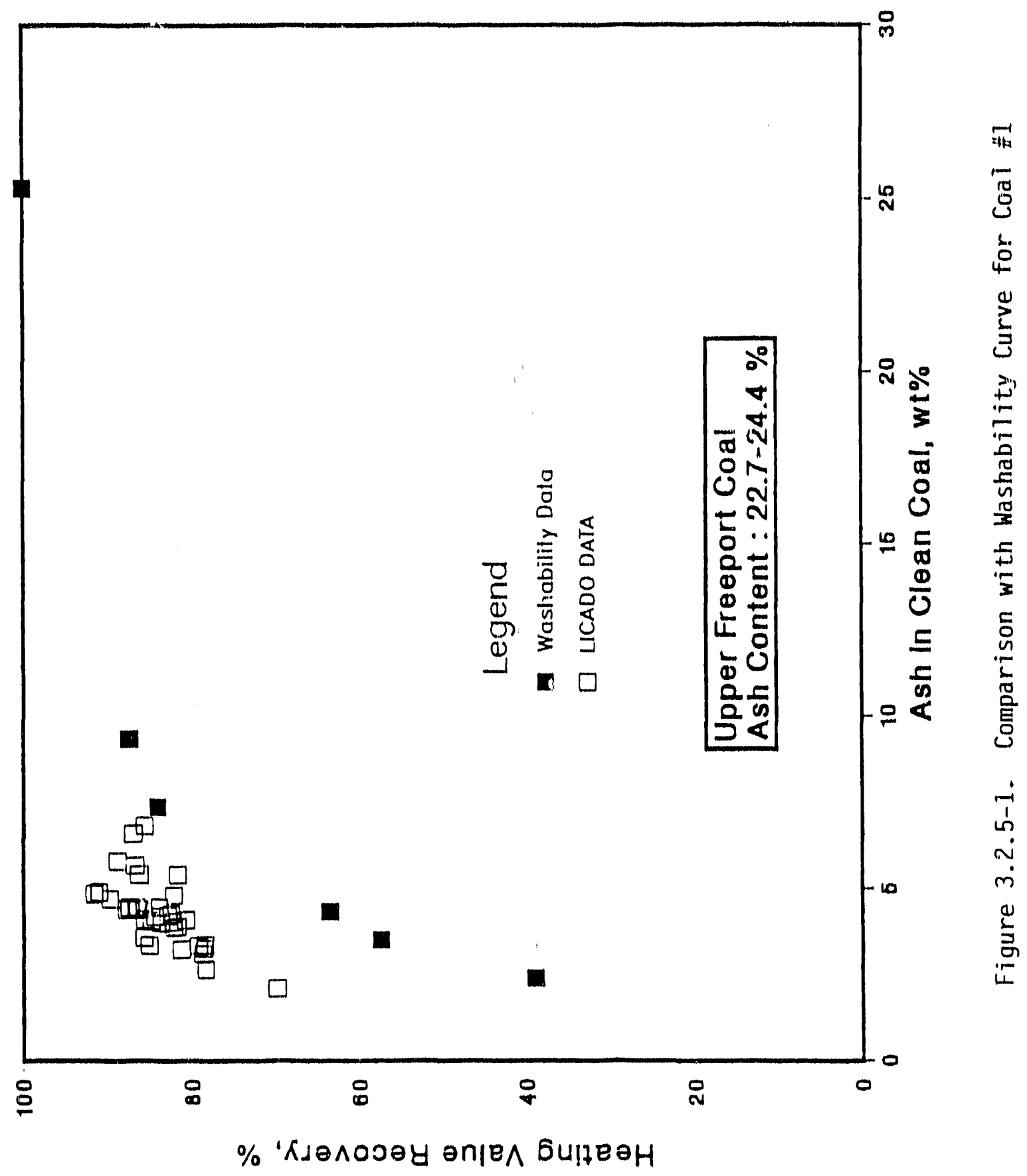




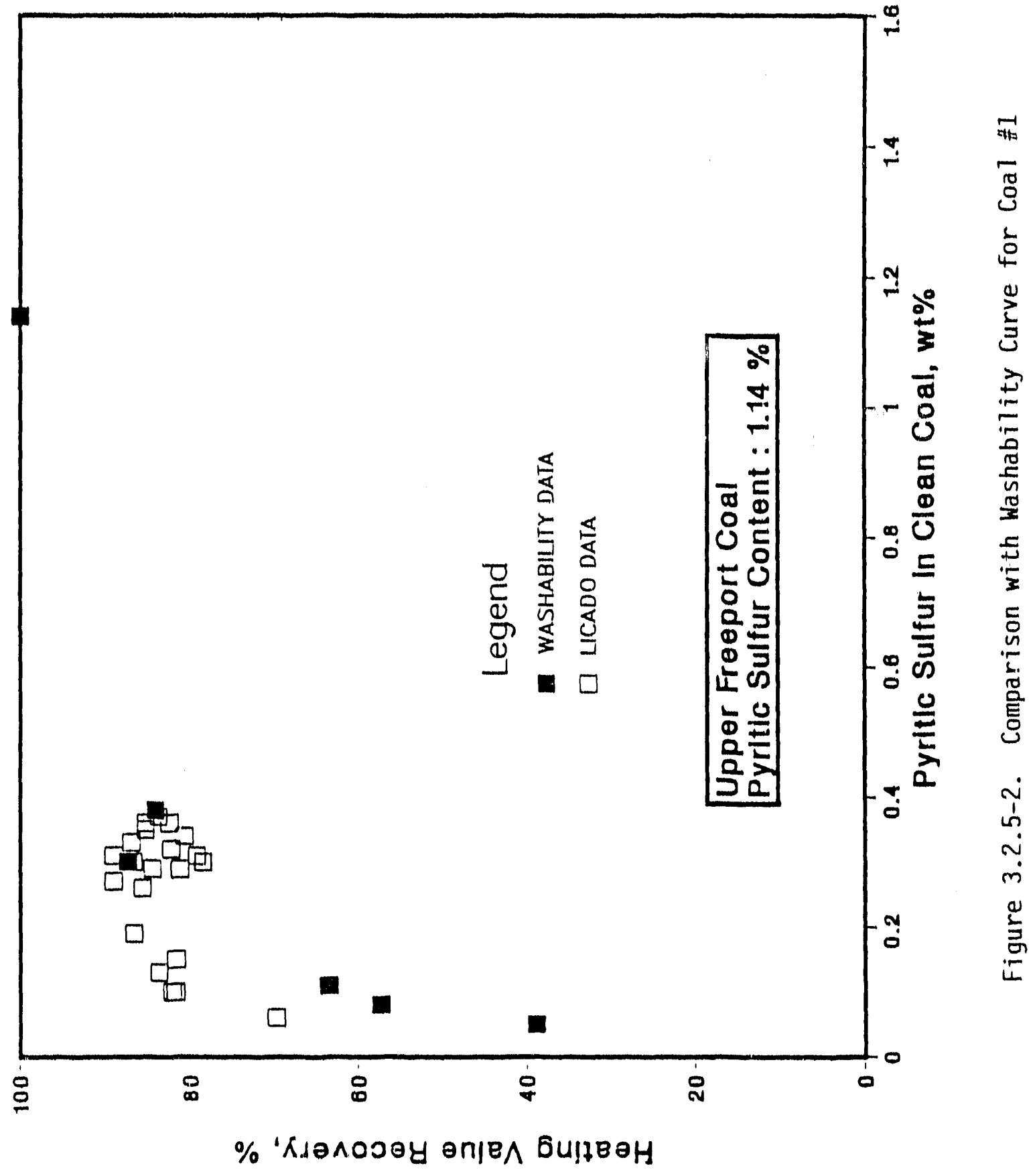




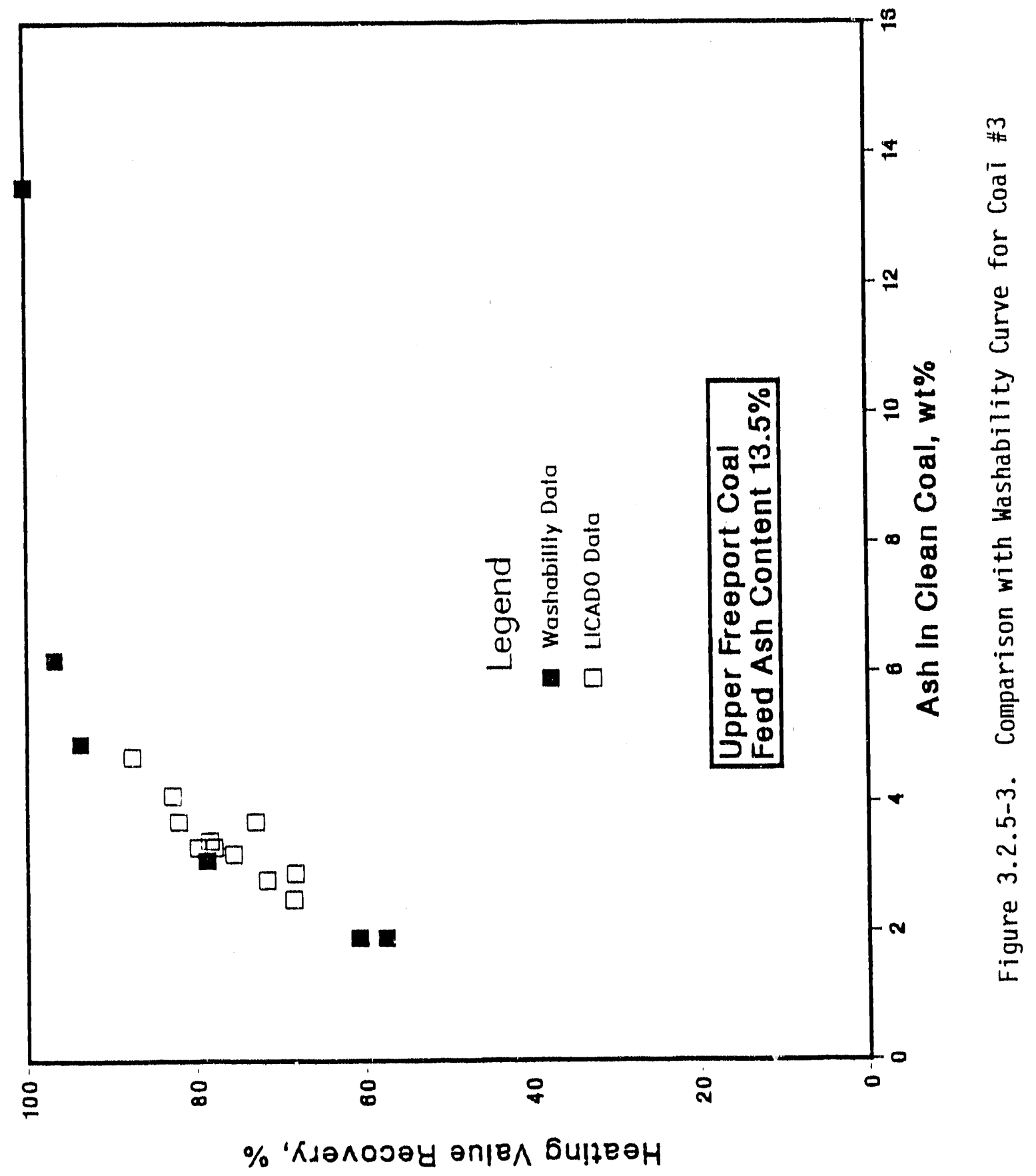


Figure 3.2.5-4 compares the performance of the LICADO process with the washability data for Middle Kittanning coal. The results compared favorably with the washability curve. Furthermore, it was possible to reduce the pioduct ash to values under $2 \%$ at heating value recoveries of nearly $80 \%$. Figure 3.2.5-5 demonstrates that, for the extremely hydrophilic Illinois No. 6 coal, it was difficult to approach the limit of separation represented by the washability surve. However, improvements in process performance could be achieved by conditioning the coal with 1-Octanol. Again, this demonstrates the importance of coal surface properties for the LICADO process.

\subsection{Agglomeration/Screening Tests}

The Batch Research Unit was modified in order to carry out agglomeration experiments to simulate the conventional oil agglomeration process. The procedure for operation of screen tests in the BRU is given below. The operation is slightly different from that used for batch tests. This section describes the results from the agglomeration screening tests. Again, this additional work was not specified in the original project proposal and was carried out after completing the work described in sections 3.1 and 3.2 .

\subsubsection{Equipment}

The 2-inch Batch Research Unit (BRU), as described earlier in section 3.1, was modified by incorporating a 175 micron ( 80 mesh) screen inside the ball valve of the equipment. The screen was inserted inside the ball valve to capture and retain the clean coal agglomerates when the coal-liquid $\mathrm{CO}_{2}$-water mixture was drained to the bottom through the ball valve. The equipment for the screen agglomeration tests is shown in Figure 3.3.1-1. 


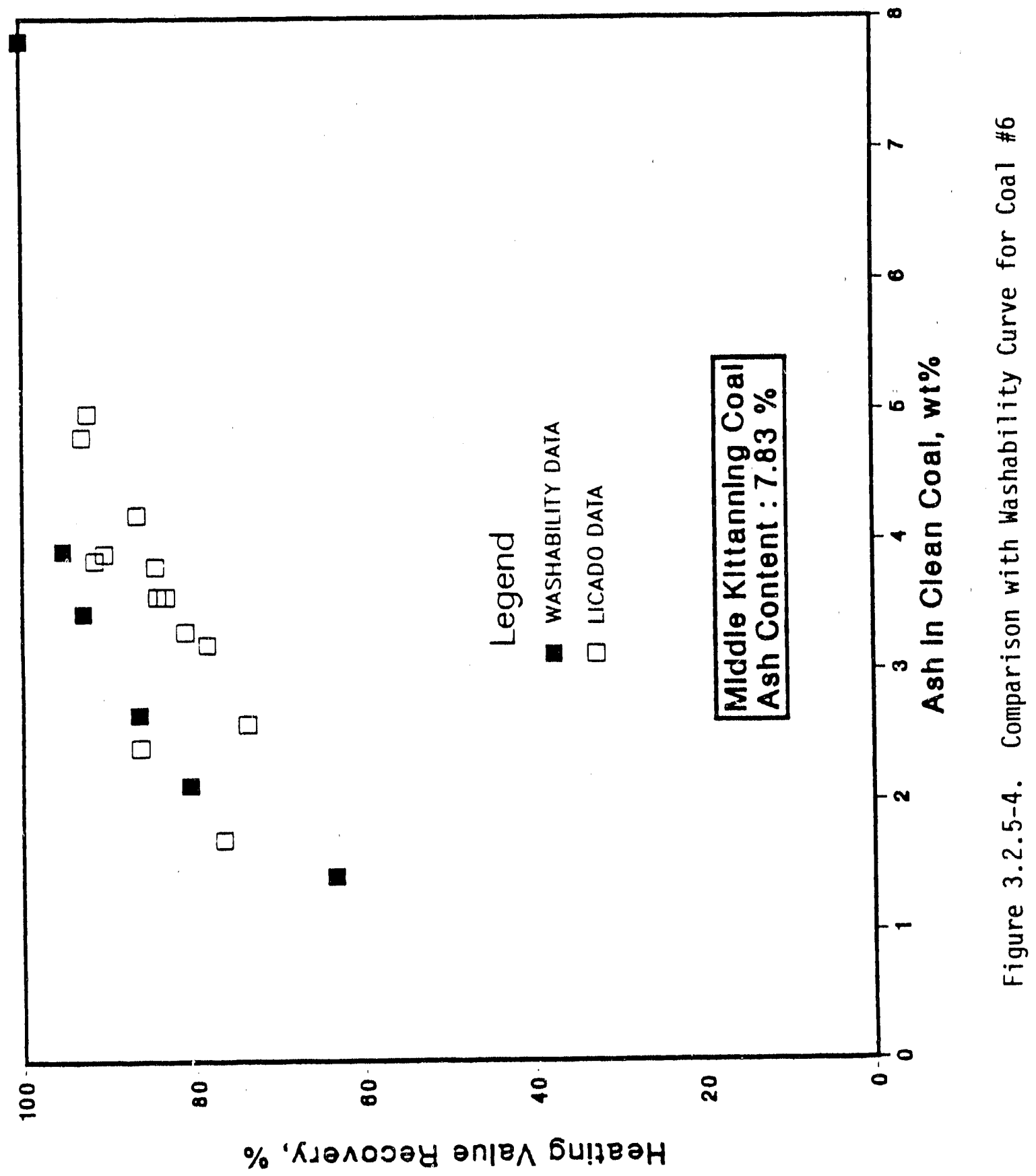




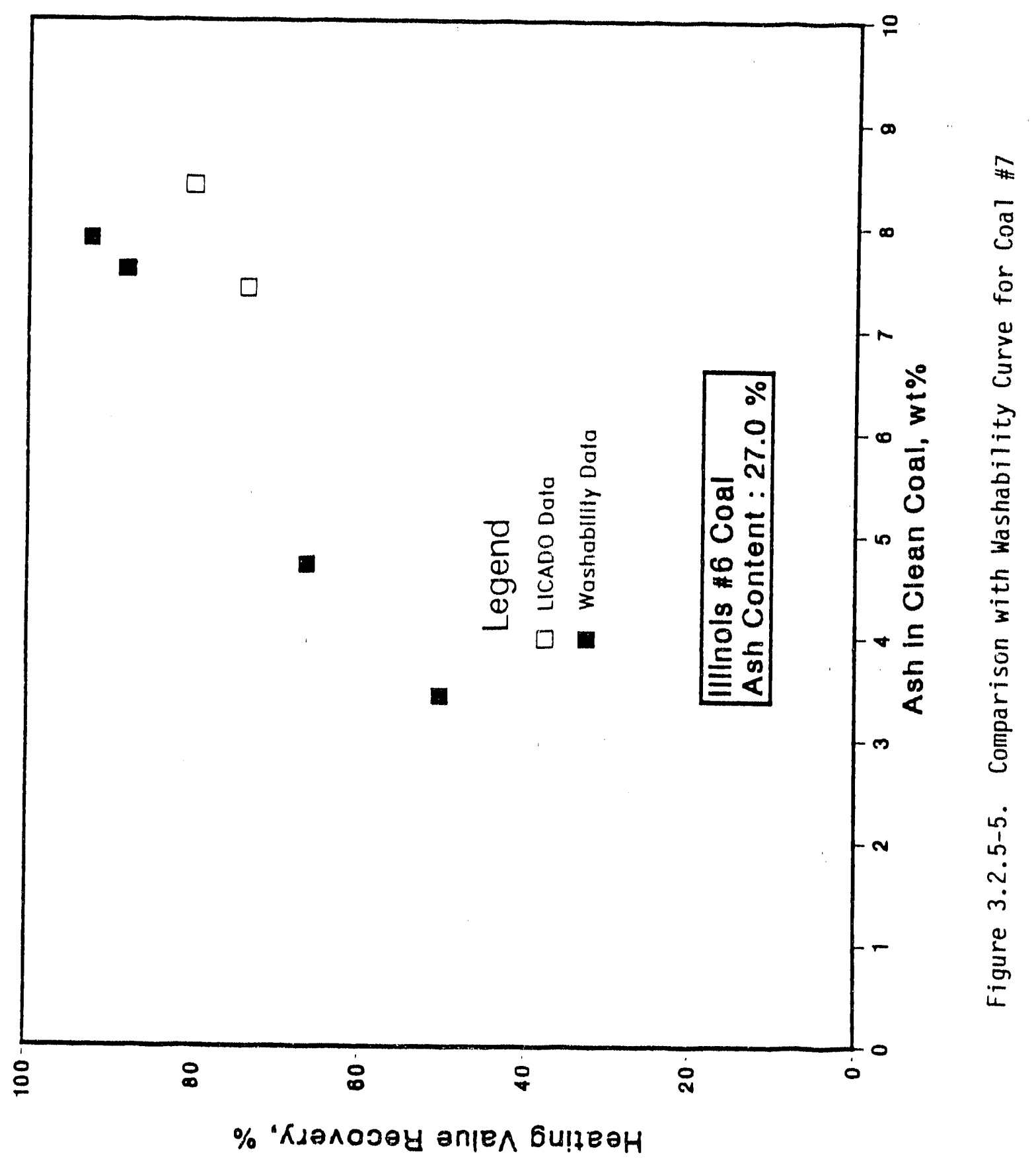




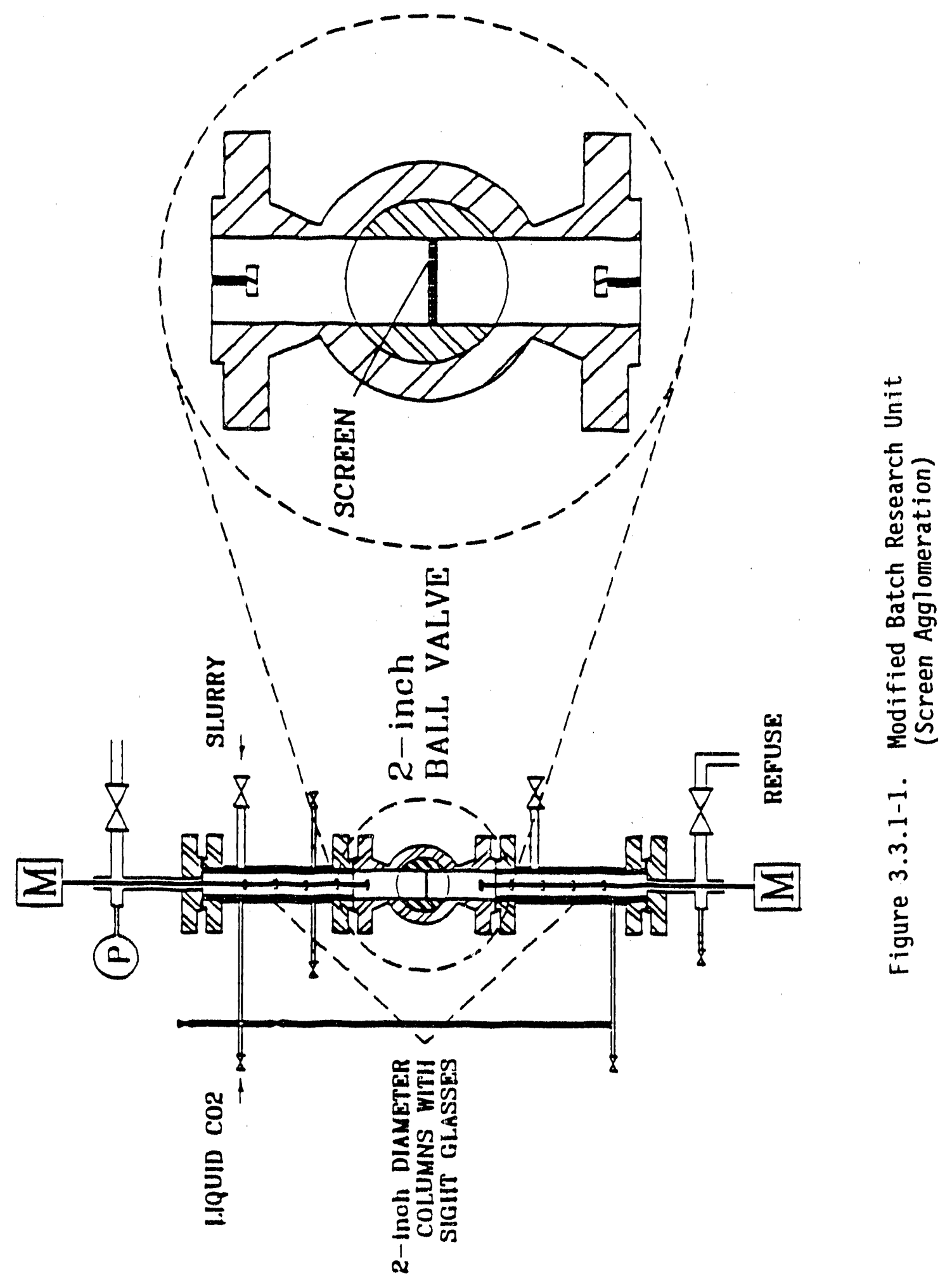




\subsubsection{Procedure}

The volume of coal slurry was maintained constant at $0.0005 \mathrm{~m}^{3}$ (500 $\mathrm{ml}$ ), and the slurry was introduced into the top cell after the ball valve was closed. The system was then pressurized with liquid $\mathrm{CO}_{2}$ until a small amount of liquid $\mathrm{CO}_{2}$ was observed to collect as a clear layer above the coal slurry. A systematic study of the influence of the volume of liquid $\mathrm{CO}_{2}$ had indicated that a volume of $0.0001 \mathrm{~m}^{3}(100$ $\mathrm{ml)}$ above the interface would be adequate, and this volume of liquid $\mathrm{CO}_{2}$ was used in all subsequent experiments. The mixing speeds were varied from 42 to $420 \mathrm{rad} / \mathrm{s}$ (400 to $4000 \mathrm{rpm}$ ) to examine the effect of agitation on process performance. The liquid $\mathrm{CO}_{2}$ was mixed vigorously with the coal slurry for $60 \mathrm{~s}$ at the desired agitation speed. Subsequently, the slurry was drained by opening the ball valve. The clean coal agglomerates were captured on the screen and collected after depressurizing the system. The overall yield and ash content of the product were then determined.

\subsubsection{Results and Discussion}

The results of the screen-type agglomeration experiments with three different coals are shown in Table 3.3.3-1. The mixing speed was maintained at $346 \mathrm{rad} / \mathrm{s}(3300 \mathrm{rpm})$ during these tests. The volume surface mean diameters of the feed coals are also given in Table 3.3.3-1. The yield was not high except for the Middle Kittanning coal. The separation characteristics were quite poor, especially for the Illinois No. 6 coal. The effects of mixing speed, particle size, and dispersants on process performance were then examined with the coal which exhibited the worst characteristics, the hydrophilic Illinois No. 6 coal.

Table 3.3.3-2 shows the yield and ash in the product obtained for the Illinois No. 6 coal when the agitation speed was altered over a range of 157 to $420 \mathrm{rad} / \mathrm{s}$ (1500 to $4000 \mathrm{rpm}$ ). The yield appears to go through a 
maximum, but the product ash is not much affected. It is apparent that no significant advantage could be gained by changing the mixing speed for the particle size employed. The overall process performance was quite poor under these conditions.

Table 3.3.3-1

Screen Agglomeration Experiments with Various Coals

\begin{tabular}{|c|c|c|c|c|c|}
\hline Coal & $\begin{array}{c}\text { Feed } \\
\text { Ash } \\
(\%)\end{array}$ & $\begin{array}{c}\text { Particle } \\
\text { Size } \\
\text { (microns) }\end{array}$ & $\begin{array}{c}\text { Yield } \\
(\%)\end{array}$ & $\begin{array}{c}\text { Product } \\
\text { Ash } \\
(\%)\end{array}$ & $\begin{array}{c}\text { Ash } \\
\text { Reduction } \\
(\%)\end{array}$ \\
\hline $\begin{array}{c}\text { Upper } \\
\text { Freeport } \\
(\# 2)\end{array}$ & 22.7 & 24.7 & 59.1 & 16.7 & 25.6 \\
$\begin{array}{c}\text { Middle } \\
\text { Kittanning } \\
(\# 6)\end{array}$ \\
$\begin{array}{c}\text { I11inois } \\
\text { No. } \\
(\# 7)\end{array}$ & 26.0 & 33.3 & 42.1 & 23.1 & 11.0 \\
\hline
\end{tabular}

The effect of particle size was also investigated on the Illinois No. 6 coal by selecting a narrow size distribution of particles $(74 \times 44$ microns). The agitation speed was varied in these runs from $42 \mathrm{rad} / \mathrm{s}$ to $147 \mathrm{rad} / \mathrm{s}$ (400 rpm to $1400 \mathrm{rpm}$ ). Table 3.3.3-3 exhibits the experimental results for heating value recovery and the separation characteristics obtained when the agitation speed was altered in this range. It can be observed from Table 3.3.3-3 that the higher agitation speeds were conducive to achieving not only high heating value recoveries greater than $80 \%$, but also lowered ash in the product, in sharp contrast to the results presented in Table 3.3.3-2. This indicates that improved dispersion and attachment of liquid $\mathrm{CO}_{2}$ droplets to the clean coal were achieved at the higher agitation speeds for samples of narrow particle size distribu- 
tion. The separation of mineral matter was increased by removing the very fine particles (below 44 microns). Thus, using a narrow size distribution and removing the fine slime coating gave rise to higher recoveries and improved separation. However, the study was not extended to higher agitation speeds, since the results in Table 3.3.3-2 demonstrated that reduced yields were obtained at higher agitation speeds.

Table 3.3.3-2

Effect of Agitation Speed

Particle Size (Surface Volume Mean Diameter): 33.3 microns Illinois No. 6 coal

\begin{tabular}{|c|c|c|c|}
\hline $\begin{array}{c}\text { Agitation } \\
\text { Speed } \\
\text { (rad/s) }\end{array}$ & $\begin{array}{c}\text { Yield } \\
(\%)\end{array}$ & $\begin{array}{c}\text { Product } \\
\text { Ash } \\
(\%)\end{array}$ & $\begin{array}{c}\text { Ash } \\
\text { Reduction } \\
(\%)\end{array}$ \\
\hline \hline 157 & 11.7 & 20.8 & 19.9 \\
260 & 46.4 & 22.9 & 12.0 \\
346 & 42.1 & 23.1 & 11.0 \\
420 & 25.6 & 22.5 & 13.6 \\
\hline
\end{tabular}

The effect of dispersants on process performance in the screen type agglomeration studies was also investigated. Three different dispersants were employed at a concentration of $20 \mathrm{ppm}$ in solution. These included Sodium Hexametaphosphate (SHMP), Sodium Silicate (SS), and 1-0ctanol. Each of them was mixed vigorously with the slurry prior to the experiment. Illinois No. 6 coal was again utilized for these tests with an average particle size of 33 microns. The mixing speed was maintained constant at $346 \mathrm{rad} / \mathrm{s}(3300 \mathrm{rpm})$. The results indicated that there was no significant improvement in the yield in the presence of the dispersants SHMP and SS. However, pretreatment with 1-0ctanol appeared to enhance the separation characteristics. 
Table 3.3.3-3

Effect of Agitation Speed on Samples of Narrow Particle Size Distribution (74 $\times 44$ microns)

Illinois No. 6 Coal

\begin{tabular}{|l|c|c|c|c|c|}
\hline No. & $\begin{array}{c}\text { Agitation } \\
\text { Speed } \\
(\mathrm{rad} / \mathrm{s})\end{array}$ & $\begin{array}{c}\text { Heating Value } \\
\text { Recovery } \\
(\%)\end{array}$ & $\begin{array}{c}\text { Ash in } \\
\text { Clean Coal } \\
(\%)\end{array}$ & $\begin{array}{c}\text { Ash in } \\
\text { Refuse } \\
(\%)\end{array}$ & $\begin{array}{c}\text { Ash } \\
\text { Reduction } \\
(\%)\end{array}$ \\
\hline \hline 1. & 42 & 40.1 & 25.8 & 32.0 & 17.8 \\
2. & 126 & 75.7 & 17.4 & 45.4 & 44.6 \\
3. & 147 & 87.1 & 14.3 & 56.9 & 54.5 \\
\hline \hline
\end{tabular}

Based on the above finding, further experiments were conducted in the presence of 1-0ctanol with one additional coal listed in Table 3.3.3-1 (Middle Kittanning coal). The average particle size of the samples was nominally -74 microns. The results for Middle Kittanning coal and Illinois No. 6 coal are shown in Table 3.3.3-4. For Middle Kittanning coal, there was no lowering of ash in the product after conditioning with 1-octanol. However, there was a steady increase in the heating value recovery, from $70 \%$ without the reagent to $87 \%$ with $220 \mathrm{ppm}$ of $1-0 \mathrm{ctanol}$. In the case of Illinois No. 6 coal, a significant improvement was observed in both the heating value recovery and separation of mineral matter. The heating value recovery was enhanced from $48 \%$ to $84 \%$ after pretreatment with 1-0ctanol solution at a concentration of $210 \mathrm{ppm}$, while the product ash content decreased from $15.8 \%$ to $14.3 \%$. It could be speculated that the $-\mathrm{OH}$ group on the alcohol adsorbed preferentially on the coal surface, while the hydrocarbon tail group was oriented towards the bulk solution, thereby increasing the hydrophobicity of the coal particles. At a much higher dosage of $1000 \mathrm{ppm}$, the reagent behaved as a dispersant as the heating value recovery declined slightly to $77 \%$, while the product ash decreased to $11.8 \%$. 
Table 3.3.3-4

Screen-type Agglomeration Experiments

Reagent: 1-Octanol

\begin{tabular}{|c|c|c|c|c|}
\hline Coal & $\begin{array}{c}\text { Dispersant } \\
\text { Conc. } \\
(\mathrm{ppm})\end{array}$ & $\begin{array}{c}\text { Product } \\
\text { Ash } \\
(\%)\end{array}$ & $\begin{array}{c}\text { Heating Value } \\
\text { Recovery } \\
(\%)\end{array}$ & $\begin{array}{c}\text { Ash } \\
\text { Reduction } \\
(\%)\end{array}$ \\
\hline \hline Middle Kittanning & 0 & 3.9 & 70.7 & 50.4 \\
& 55 & 3.9 & 73.0 & 50.4 \\
& 105 & 3.9 & 80.9 & 50.4 \\
I11 inois No.6 & 320 & 3.9 & 87.7 & 50.4 \\
& 30 & 16.8 & 48.3 & 39.9 \\
& 120 & 14.1 & 81.6 & 45.9 \\
& 210 & 14.3 & 84.3 & 45.1 \\
& 1000 & 11.8 & 77.0 & 55.0 \\
\hline \hline
\end{tabular}

A comparison of the screen-type agglomeration experiments and the variable volume batch operation can be made for the high ash Illinois No. 6 coal (coal \#7). The results obtained in the $0.10 \mathrm{~m}$ (4-inch) RDU were described in section 3.2.3 (Table 3.2.3-5) with and without conditioning the coal in 1-Octanol solutions. The RDU test results provided lower ash contents in the product compared to those obtained in the screen agglomeration tests. The heating value recoveries obtained after conditioning with 1-0ctanol are comparable in both types of tests. It can be inferred that the variable volume batch operation is more favorable for achieving improved process performance. It must be emphasized that, while the screen-type aggiomeration experiments provide a quick method to determine the trend of the results, the variable volume operation is the preferred method to provide desirable process performance. 


\section{REFERENCE}

3-1. B. I. Morsi et a1, "Coal Surface Control for Advanced Physical Fine Coal Cleaning Technologies" Annual Report (1988-89) submitted to the Department of Energy. 


\subsection{CONTINUOUS RESEARCH UNIT}

A Continuous Research Unit (CRU) was designed, constructed, and operated to demonstrate the performance of an integrated LICADO process. The system was designed for a capactty of $0.45-4.53 \mathrm{~kg} / \mathrm{s}(1-10 \mathrm{lb} / \mathrm{hr})$. The design of the CRU is principally based on the experience gained from extensive testing in the RDU and BRU. The diameter of the separator in the RDU is also $0.10 \mathrm{~m}$ (4-inches), and the experimental data from RDU and BRU experiments were used as the basis for the design of the CRU. Cold model experiments and computer simulation of high pressure discharge operations were also utilized to simulate the critical operating components prior to construction. The operation is fully automated. Both process control and data logging are performed using a personal computer interfaced with the gauges, valves, and pumps in the system.

\subsection{Equipment}

A flow diagram of the CRU is shown in Figure 4.1-1. A photograph of the unit is provided in figure 4.1-2. The CRU is mounted on a steel frame $3.04 \mathrm{~m}(10 \mathrm{ft})$ long, $1.52 \mathrm{~m}(5 \mathrm{ft})$ wide, and $5.5 \mathrm{~m}(18 \mathrm{ft})$ in height. A detailed description of the principal components of the system is given below.

\subsubsection{Clean Coal/Refuse Separator}

The central unit of the LICADO continuous system is the separation column shown in Figure 4.1-3. In this unit, the coal-water slurry is mixed with liquid $\mathrm{CO}_{2}$ to separate the clean coal from the mineral matter. The separation takes place in a $0.10 \mathrm{~m}(4-$ inch) $1 . D$. stainless steel column. Mixing is provided by a variable speed motor. Two injection points for liquid $\mathrm{CO}_{2}$ and one for the coal-water slurry are provided, and their vertical positions can be adjusted along the column. Both column ends are of conical shape, in order to eliminate any solids accumulation and to facilitate their removal from the unit. 


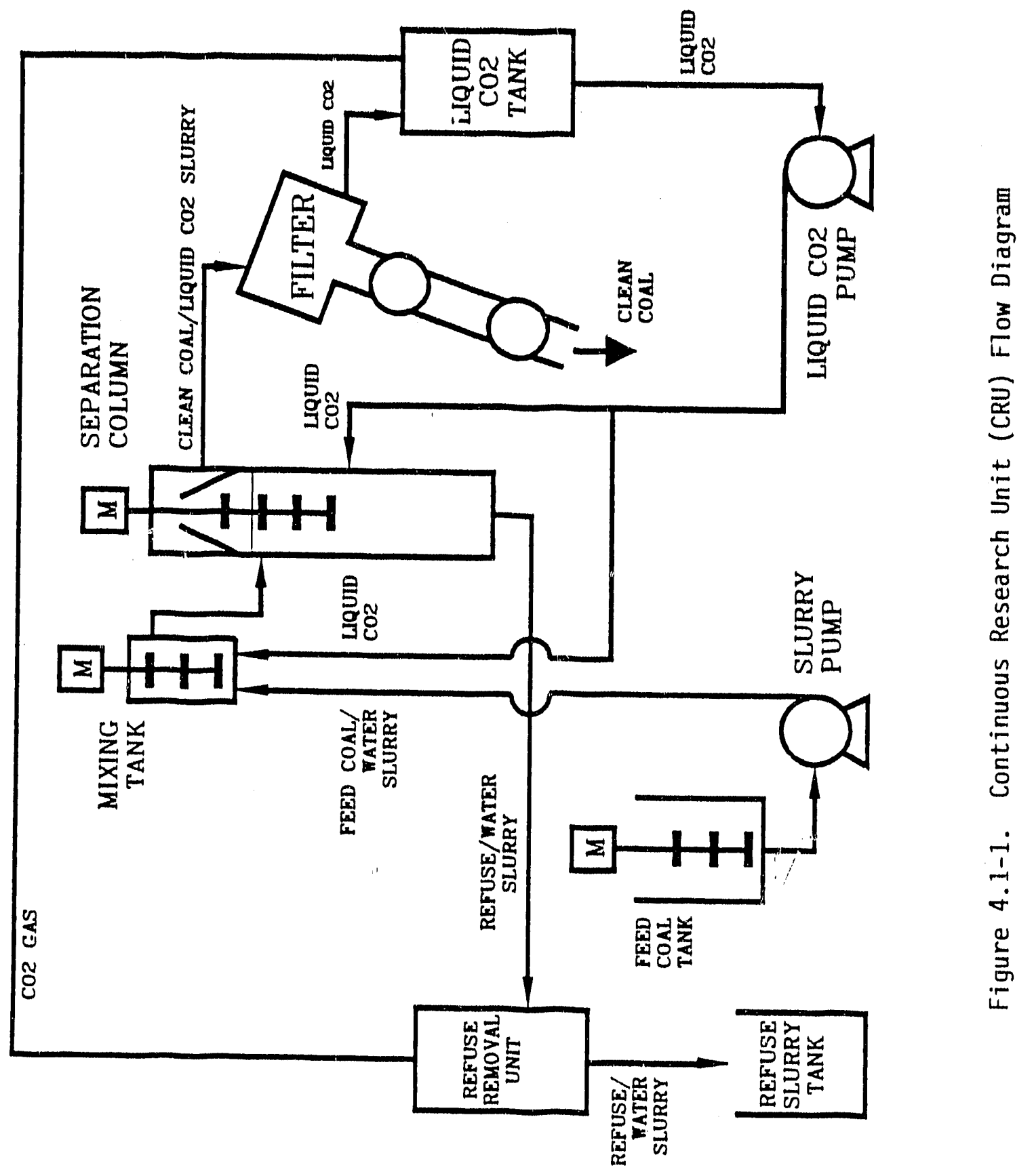




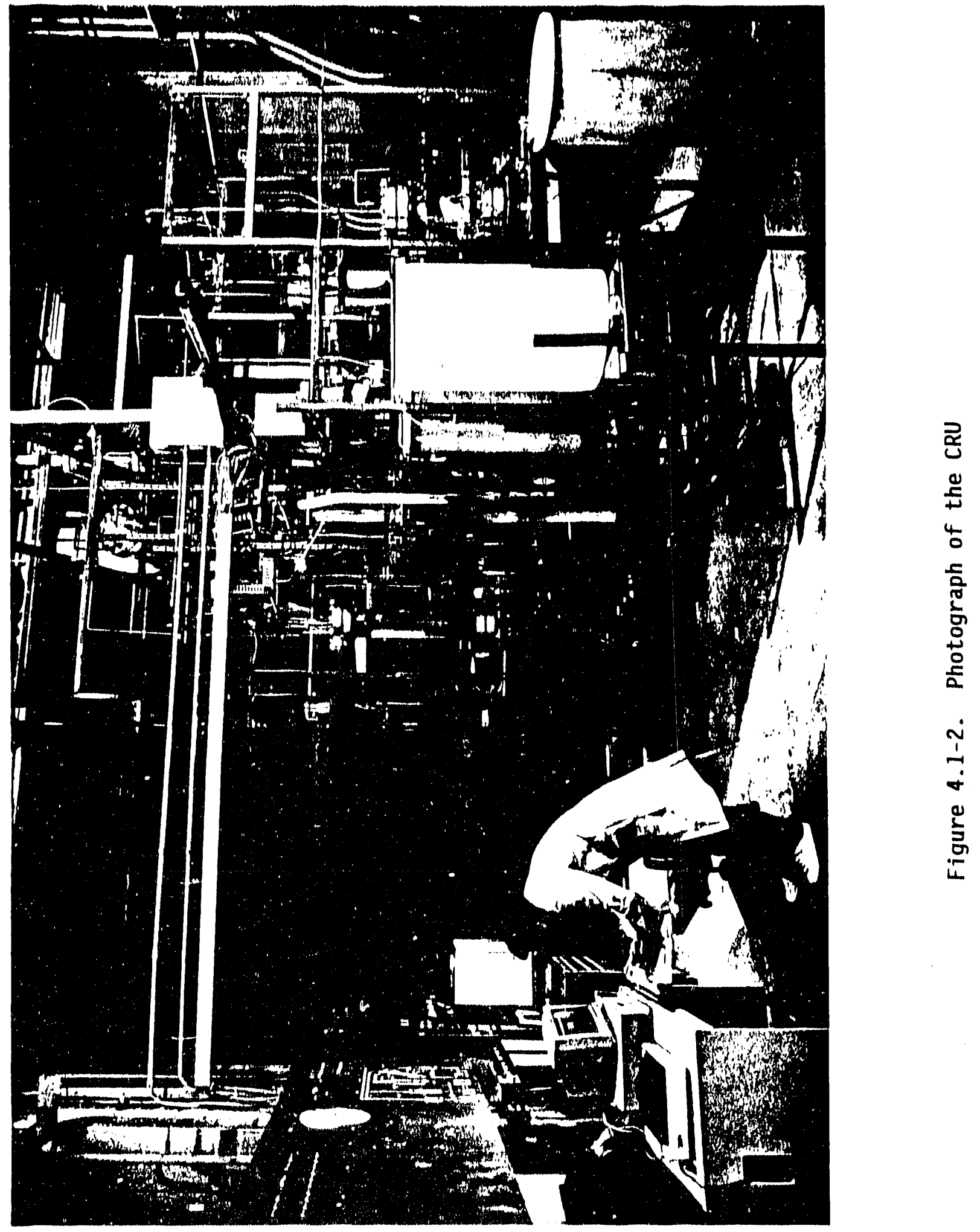




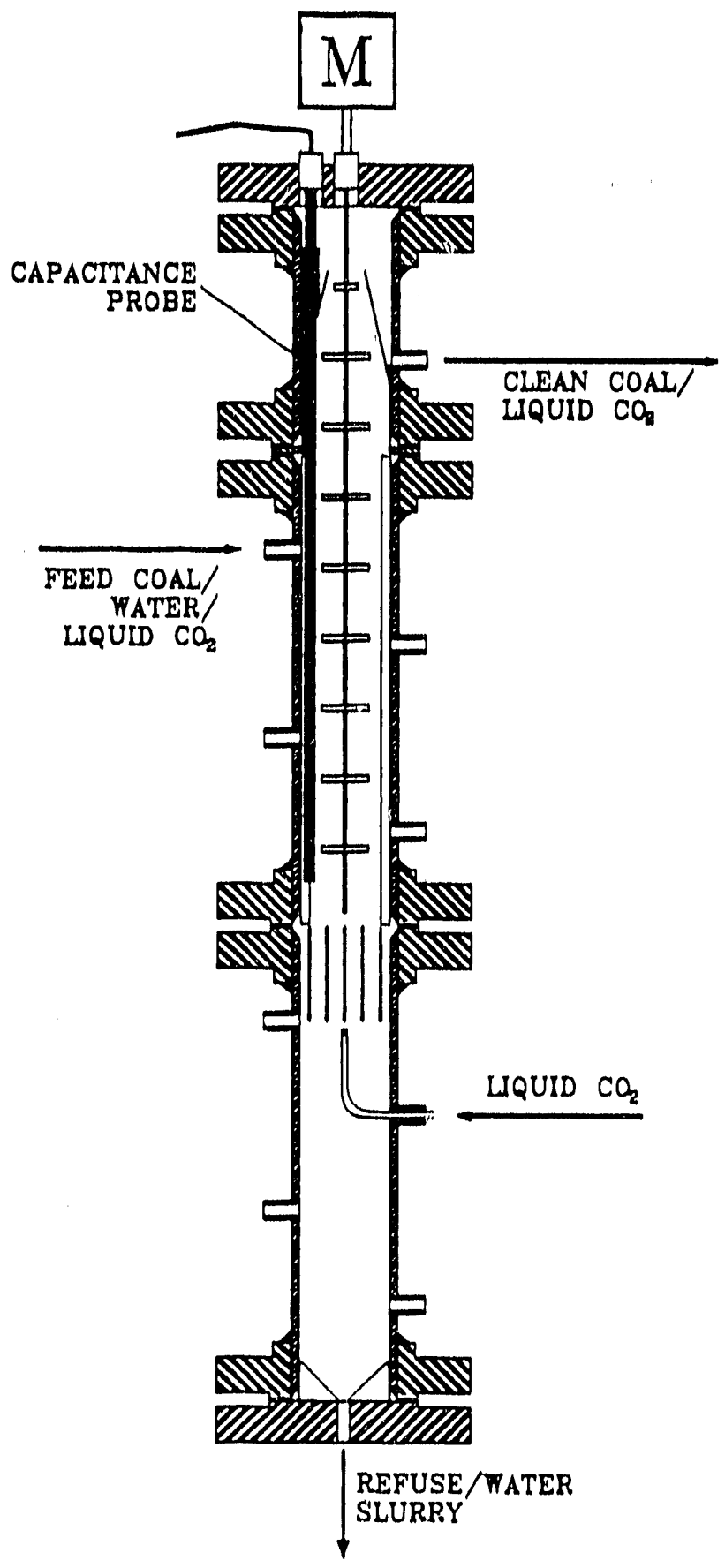

Figure 4.1-3. Separation Column 
The clean coal-liquid $\mathrm{CO}_{2}$ product stream is removed from the top of the unit through a tube leading to a high pressure clean coal filter. On the other hand, the refuse stream is continuously withdrawn from the bottom of the unit. The position of the liquid $\mathrm{CO}_{2}$-water interface is controlled using a capacitance probe coupled with a regulating valve for the withdrawal of the refuse/water slurry from the bottom of the separation column.

\subsubsection{Premixing Tank}

A premixing tank was designed and installed for high-shear agglomeration of feed coal with liquid $\mathrm{CO}_{2}$ from the slurry injection to the separation column. This device was used to increase the capacity of the system and improve the quality of the clean coal product. Figure 4.1-4 shows the premixing unit of $0.101 \mathrm{~m}(4$-inch) I.D. and a height of $0.51 \mathrm{~m}(20$ inches) equipped with a mixer which can operate up to $210 \mathrm{rad} / \mathrm{s}$ (2000 rpm).

\subsubsection{Slurry Preparation Unit}

This unit consists of a $0.21 \mathrm{~m}^{3}$ (55-gallon) plastic stirred tank and a high pressure slurry pump. The feed coal-water slurry is prepared in the tank. Mixing in the tank is provided using two four-pitched blade impellers driven by a $0.19 \mathrm{~kW}(1 / 4 \mathrm{hp})$ motor. The coai-water slurry is transported into the separation vessel by the slurry pump. The pump is specified to develop a maximum discharge pressure of $8612 \mathrm{kPa}$ (1250 psig) and a maximum slurry flowrate of $0.075 \mathrm{~m}^{3} / \mathrm{s}$ (72 gph).

\subsubsection{Clean Coal/Liquid $\mathrm{CO}_{2}$ Separator}

The clean coal leaves the separation column in the form of an agglomerate with liquid $\mathrm{CO}_{2}$ and a small amount of water. In order to remove the clean coal from the mixture with minimum losses, a high pressure filter 


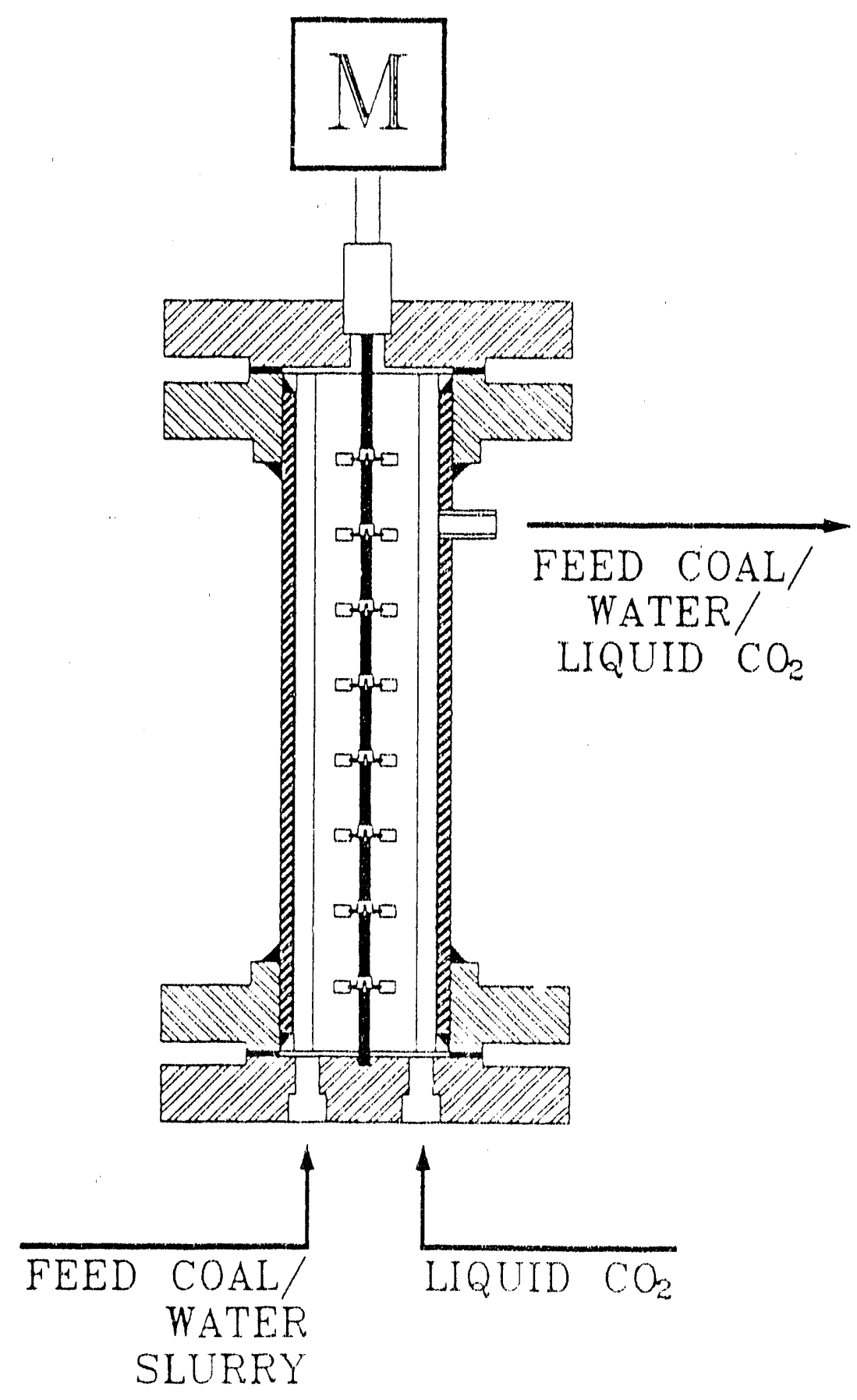

Figure 4.1.4. Premixing Tank 
was designed and installed. The high pressure filter, shown in Figure 4.1-5, is composed of a porous tube enclosed in a $0.15 \mathrm{~m}$ (6-inch) I.D. stainless steel tee. The clearl coal-liquid $\mathrm{CO}_{2}$ slurry is fed inside the porous 1 tube, and the liquid $\mathrm{CO}_{2}$ is filtered out through its wall. The clean coal is removed by a variable pitch auger driven by an external high torque motor and falls into a $0.05 \mathrm{~m}$ (2-inch) I.D., $0.31 \mathrm{~m}$ (12-inch) long container. The container can be depressurized, emptied, and repressurized by operating a vent, a connection to a $\mathrm{CO}_{2}$ source and two 2 -inch pneumatically actuated ball valves at its ends. The liquid $\mathrm{CO}_{2}$ leaving the clean coal filter is recycled into the separation column so that the required makeup is minimized.

\subsubsection{Refuse/Water Separator}

The refuse is removed from the bottom of the separation column in the form of a dilute coal-water slurry. The refuse removal unit consists of two stainless steel $0.15 \mathrm{~m}$ (6-inch) diameter flanged tanks $0.51 \mathrm{~m}$ and $1.02 \mathrm{~m}$ (20 and 40 inches) tall. The refuse slurry is discharged from the column to the tanks by hydrostatic pressure (see below).

\subsection{Procedure}

A brief description of the operating procedure for the CRU is given below:

1. Coal-Water Slurry Preparation

a. The original coal sample is crushed in a jew crusher and pulverizer to $0.003 \mathrm{~m} \times 0\left(1 / 8^{\prime \prime} \times 0\right)$.

b. Further size reduction is achieved by wet grinding using a stirred ball mill. For each batch, $1.81 \mathrm{~kg}(4 \mathrm{lb})$ of coal and $4.1 \mathrm{~kg}(9 \mathrm{lb})$ of water is ground using $1.36 \mathrm{~kg}(30 \mathrm{lb})$ of stainless steel balls of $0.009 \mathrm{~m}\left(3 / 8^{\prime \prime}\right)$ size. The resulting slurry is wet screened to remove particles larger than +590 micron (+ 28 inesh). 


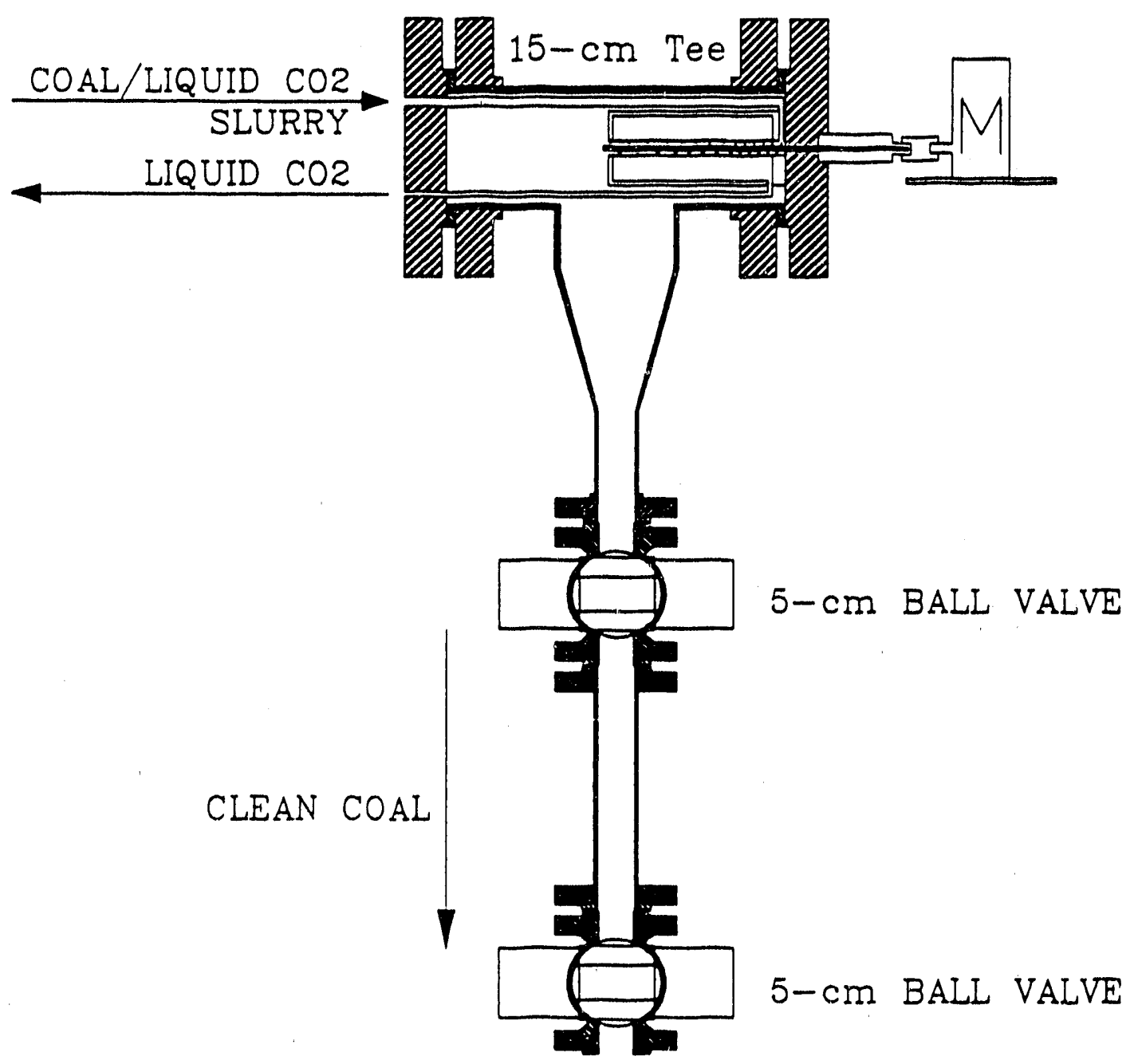

Figure 4.1-5. Clean Coal Filter 
c. The slurry is loaded into the feed tank, and water is added to adjust the slurry concentration to a predetermined value. The mixer is turned on to prevent coal settling.

2. Continuous Operation Start-Up

a. Turn on the main power for the CRU.

b. Load liquid $\mathrm{CO}_{2}$ into the liquid $\mathrm{CO}_{2}$ tank.

c. Check the pneumatic valves, the pumps, and gauges to insure their proper working condition.

d. Run the continuous system program. This program interactively performs the following sequence of operations needed to start-up the unit:

- Reset relays and regulating valves.

- Display, set, and log operating conditions.

- Determine control parameters.

- Pressurize the system.

- Add water to the separation column.

- Turn on the stirrer motors.

- Start liquid $\mathrm{CO}_{2}$ injection into the premixing tank and separation column.

- Start coal-water slurry injection into premixing tank.

3. Operation Management and Control

The operation of the CRU is controlled by a personal computer using a continuous system program. The program allows for the display of all the variables measured. It is also possible to adjust operating conditions in terms of the liquid $\mathrm{CO}_{2}$ flowrate, the interface position in the separation column, and the clean coal discharge time interval without interrupting the operation. 


\subsubsection{Continuous Operation Control Schemes}

The operation of the CRU is fully automated. A microcomputer furnished with a 32 channel $A / D$ input board, an 8 channel D/A output board, and a 16 channel relay card is interfaced with the equipment control valves and measurement devices.

The signals from 16 measurement devices are used to control three regulating valves, eight ball valves, and two pumps. The signals from four pressure transducers, four thermocouples, two flowmeters, a liquid $\mathrm{CO}_{2}$-water interface 1 indicator, and five level alarms are received by an $A / D$ colveriter module and read by a microcomputer. The system information is processed and used to control the equipment operation. The 4-20 $\mathrm{mA}$ output signals are sent to the pneumatic regurating valves via a $D / A$ converter module. The ball valves and the pumps are operated using a relay output card.

Eight pneumatic ball valves, the high pressure slurry pump, and the liquid $\mathrm{CO}_{2}$ recirculation pump can be operated manually from a control panel or switched to computer control mode. The measurements from the pressure transducers, the level indicators, and the Coriolis type mass flowmeters are displayed on the control panel and also received by the computer via an $A / D$ board.

Considerable efforts were devoted to updating and refining the process control schemes for the continuous operation of the LICADO process. These include:

1. Interface position control

2. Refuse discharge control

3. Liquid $\mathrm{CO}_{2}$ flowrate control

4. Clean coal discharge control

A brief description of the main control loops is presented below. 


\subsubsection{Interface Position Control}

Figure 4.2-1 shows the equipment used for the control of the interface position in the separation column. The position is read with a $0.73 \mathrm{~m}$ (29-inch) capacitance probe which transmits the signal to the computer. In turn, the computer positions a $0.02 \mathrm{~m}(1-$ inch) pneumatic regulating valve which is used to adjust the rate of underflow from the separation column and therefore, the position of the water-iiquid $\mathrm{CO}_{2}$ interface in the separation column. The controller was tuned by first determining calibration curves for the slurry pump (as \% stroke length vs flowrate) and the regulating valve (\% open vs flowrate) using water and coal-water slurries. The system dynamic response was also studied. A software driven proportional controller was adopted.

\subsubsection{Refuse Discharge Control}

Figure 4.2-2 shows the refuse slurry discharge system. This section of the CRU operalds cyclically by automatically operating the valves connected to the thili refuse tanks. After each discharge, Tank 2 is repressurized by connelfing it to the liquid $\mathrm{CO}_{2}$ tank. When Tank 2 attains system pressurlal the two tanks are reconnected again. While Tank 2 is discharged, the refuse slurry is continuousiy transferred from the separation column to Tank 1. This procedure was tested at low pressure and was also simulated using a model based on fundamental fluid mechanics equations that inworporated the results of these tests. The simulation results were used to design the high pressure refuse removal system.

\subsubsection{Liquid $1 \mathrm{O}_{2}$ Flowrate Control}

Figure 4.2-3 depicts the liquid $\mathrm{CO}_{2}$ recirculation circuit. Liquid $\mathrm{CO}_{2}$ is injected into the mixing tank and into the separation column. The flowrate of both streams is measured using Coriolis type mass flowmeters. The signals from these devices are used to position two $0.01 \mathrm{~m}$ $(1 / 2$-inch) pneumatic regulating valves. Because a gear pump is used to 


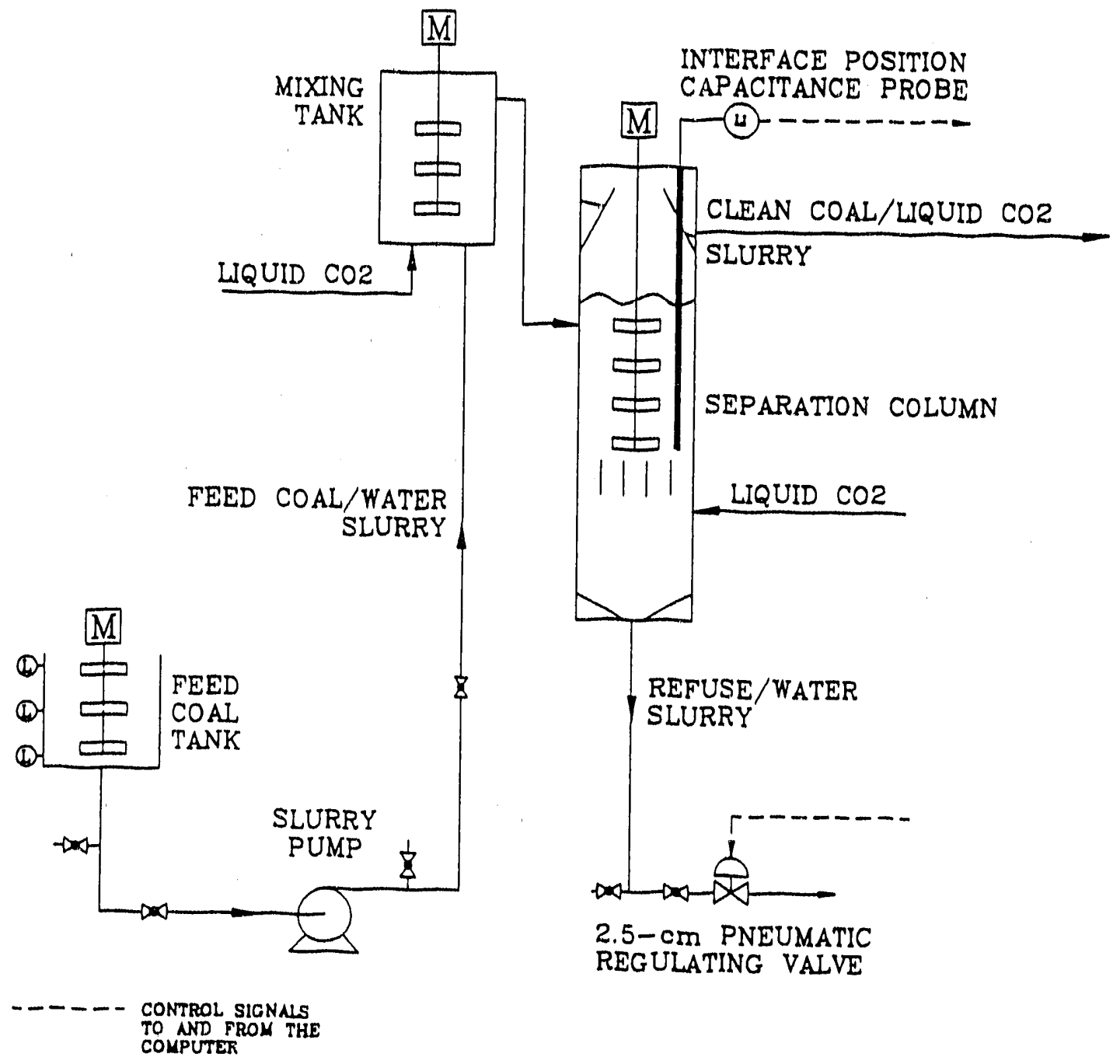

Figure 4.2-1. Interface Position Control 


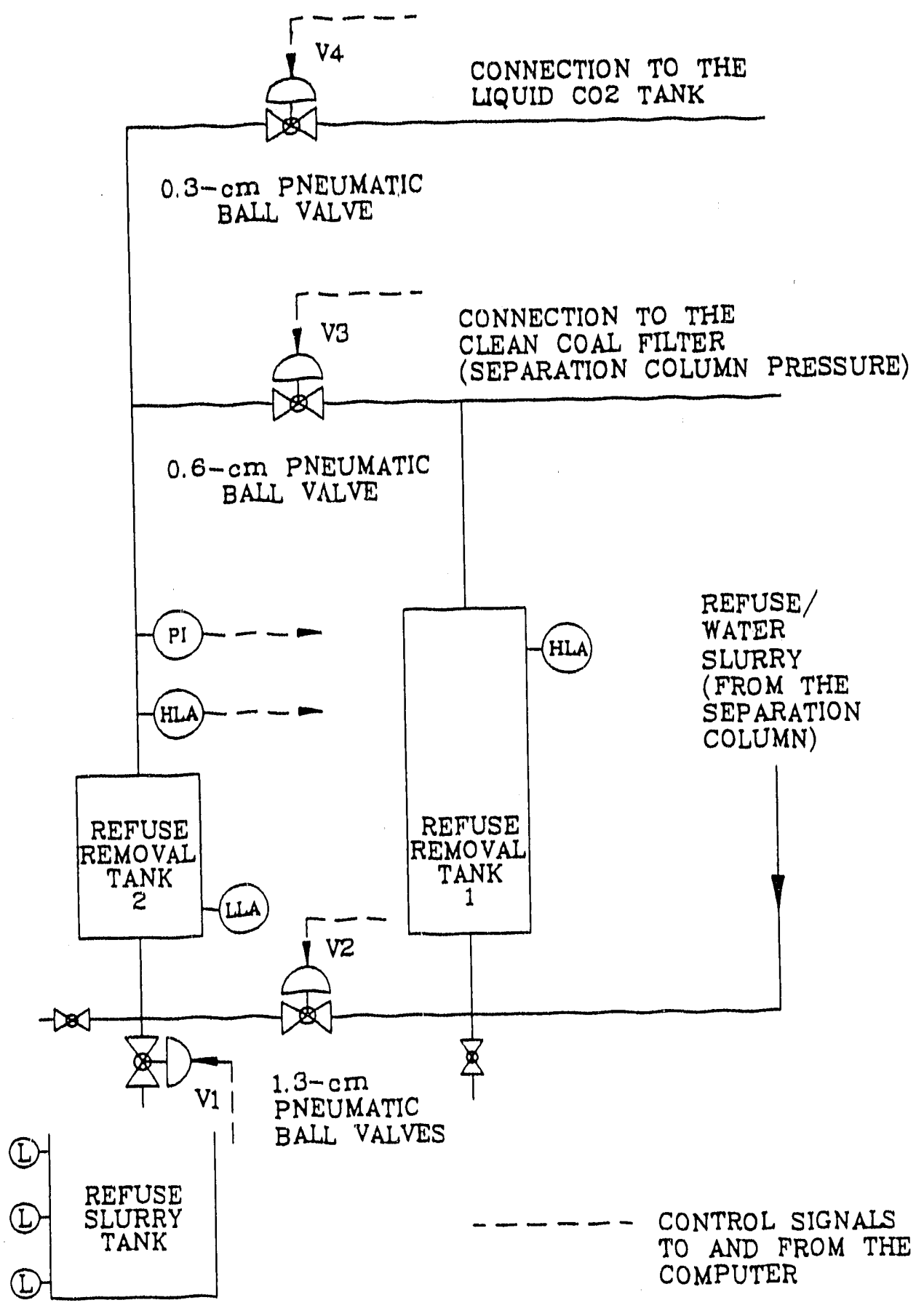

Figure 4.2-2. Refuse Discharge Control 


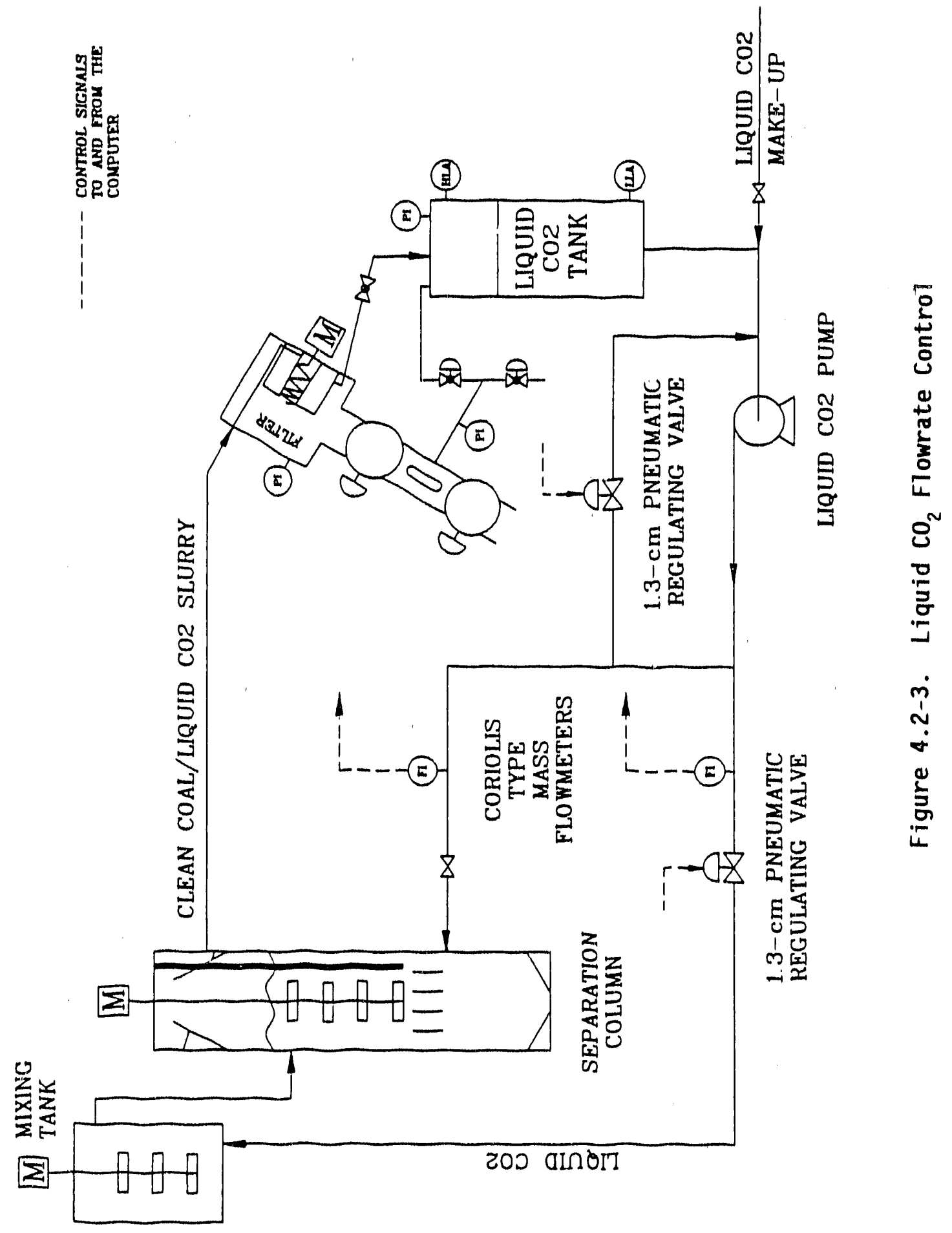


recycle liquid $\mathrm{CO}_{2}$, a bypass to the liquid $\mathrm{CO}_{2}$ tank must be provided to control the total flowrate of liquid $\mathrm{CO}_{2}$. The regulating valves are located on the bypass 1 ine and on the line carrying liquid $\mathrm{CO}_{2}$ to the mixing tank. The total liquid $\mathrm{CO}_{2}$ flowrate and the ratio between the two flowrates is calculated and used to position the valves. A manual regulating valve on the line leading to the separation column is adjusted before each experiment, depending on the flowrate values to be used in the test. A proportional-integral controller was adopted for the liquid $\mathrm{CO}_{2}$ flowrate control.

\subsubsection{Clean Coal Discharge Control}

Figure 4.2-4 shows the clean coal vessel used for the separation of clean coal from liquid $\mathrm{CO}_{2}$ and the discharge of the product. The clean coal is cyclically discharged at preset time intervals by isolating the clean coal container from the vessel, venting $i t$, and unloading the product to a receiving vessel at atmospheric pressure. The container is then depressurized and connected to the clean coal vesse1. Typical discharge intervals are $1800 \mathrm{~s}(30 \mathrm{~min})$ long. The clean coal container is unloaded at $345 \mathrm{kPa}(50 \mathrm{psig})$ to facilitate the coal discharge.

\subsection{Results and Discussion}

Most of the CRU experiments were performed with Upper Freeport coal (coal \#3). The range of operating conditions in the CRU experiments are shown in Table 4.3-1.

Initial sets of experiments were conducted without a conical section on top of the separation column. Upper Freeport coal (\#1 in Table 3.0-1) was utilized in these tests. Problems were experienced with the operation of the clean coal filter due to carryover of water from the separation vessel. Water intrusion into the pores of the filter resulted in clogging of the porous tube by the clean coal and has restricted usage of the filter. An improved design of the filter is required. 
()ㅏㅇ

(a)

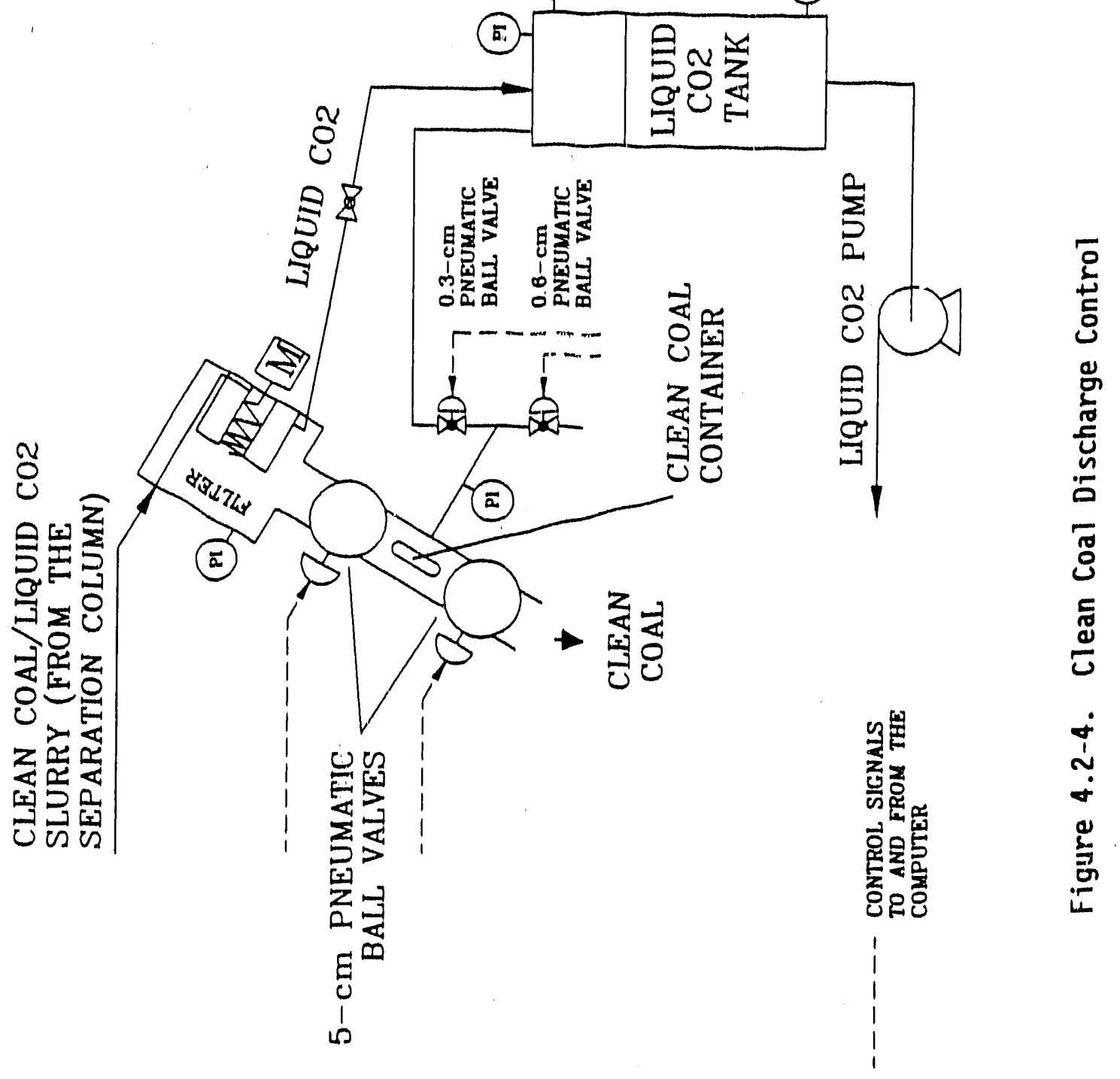


The experiments confirmed the trend observed in the batch tests, suggesting that lower mixing speed ylelds a cleaner product. A phenomenon common to all these experiments was the strong correlation between the water content and the ash content in the clean coal samples. In general, the lower water content in the product correlated well with lower ash contents in the clean coal product. Mixing speeds higher than $125 \mathrm{rad} / \mathrm{s}$ (1200 rpm) caused water entrapment in the agglomerates and, consequently, a wet product. Mixing speeds below $63 \mathrm{rad} / \mathrm{s}(600 \mathrm{rpm})$ had a similar effect, which was likely caused by poor dispersion of the liquid $\mathrm{CO}_{2}$ droplets in the slurry. The results obtained in the variable volume batch unit showed that the addition of a conical section on top of the separation column $1 \mathrm{~m}$ proves the process performance. A similar device was added to the separation column of the CRU.

Table 4.3-1

Range of Operating Conditions in CRU

\begin{tabular}{|ll|}
\hline Slurry Flowrate, $\mathrm{m}^{3} / \mathrm{s} \times 10-6$ & $1.3-15(200-900 \mathrm{ml} / \mathrm{mt}$ \\
Slurry Concentration, Wt\% & $5-10$ \\
$\begin{array}{l}\text { Slurry Injection Point, } \mathrm{m} \\
\text { (below top of cone) } \\
\text { Interface position, } \mathrm{m} \\
\text { (below top of cone) } \\
\text { Liquid CO Flowrate, } \mathrm{kg} / \mathrm{s}\end{array}$ & $0.31-0.51(12-20 \mathrm{in})$ \\
In Premixing Tank & $0.15-0.45(6-18 \mathrm{in})$ \\
In Separation Column & \\
Mixing Speed, rad/s & $0-0.01(0-600 \mathrm{~g} / \mathrm{min})$ \\
In Premixing Tank & $0.0016-0.04(100-2500 \mathrm{~g} / \mathrm{m})$ \\
In Separation Column & $125-209(1200-2000 \mathrm{rpm})$ \\
Restdence Time in Sep. Column, s & $360-1440(6-24 \mathrm{~min})$ \\
\hline \hline
\end{tabular}


Freshly ground samples of Upper Freeport coal (coal \#3) were utflized to prepare new batches of $4.8 \%$ feed coal-water slurry. Tests 31 through 37 were carried out using these slurry samples. Experiments were performed using a mixing speed of $84 \mathrm{rad} / \mathrm{s}(800 \mathrm{rpm})$, a slurry flowrate of $3.6 \mathrm{x}$ $10-6 \mathrm{~m}^{3} / \mathrm{s}(220 \mathrm{ml} / \mathrm{min})$, and an interface location of $0.30 \mathrm{~m}(12$ inches) below the top of the cone. The results of these tests are shown in Table 4.3-2.

A large reduction in the amount of water present in the clean coal samples was observed in this set of experiments. The clean coal throughput increased above $.0001 \mathrm{~kg} / \mathrm{s} \quad(0.8 \mathrm{lb} / \mathrm{hr})$ when the 1 iquild $\mathrm{CO}_{2}$ was injected at a higher point in the separation column. It is believed that entrainment of liquid $\mathrm{CO}_{2}$ in the refuse stream caused the lower yield observed in the lower injection point tests. The duration of these tests ranged from three to seven hours.

Figure 4.3-1 shows the results obtained during Test 31. The clean coal was discharged every $1800 \mathrm{~s}$, and each sample was weighed out. As can be observed from Figure 4.3-1, the clean coal output rate increases to about $0.00075 \mathrm{~kg} / \mathrm{s}(0.6 \mathrm{lb} / \mathrm{hr})$ at the higher $\mathrm{CO}_{2}$ flowrate of $0.016 \mathrm{~kg} / \mathrm{s}$ $(1000 \mathrm{gm} / \mathrm{min})$. The ash content in the product was reduced to about $4 \%$ throughout the entire duration of the test. The clean coal solid content (the amount of dry product coal as a function of the product discharge consisting of coal, water, and some $\mathrm{CO}_{2}$ ) was held nearly constant at $65 \%$ except toward the end of the test period. 


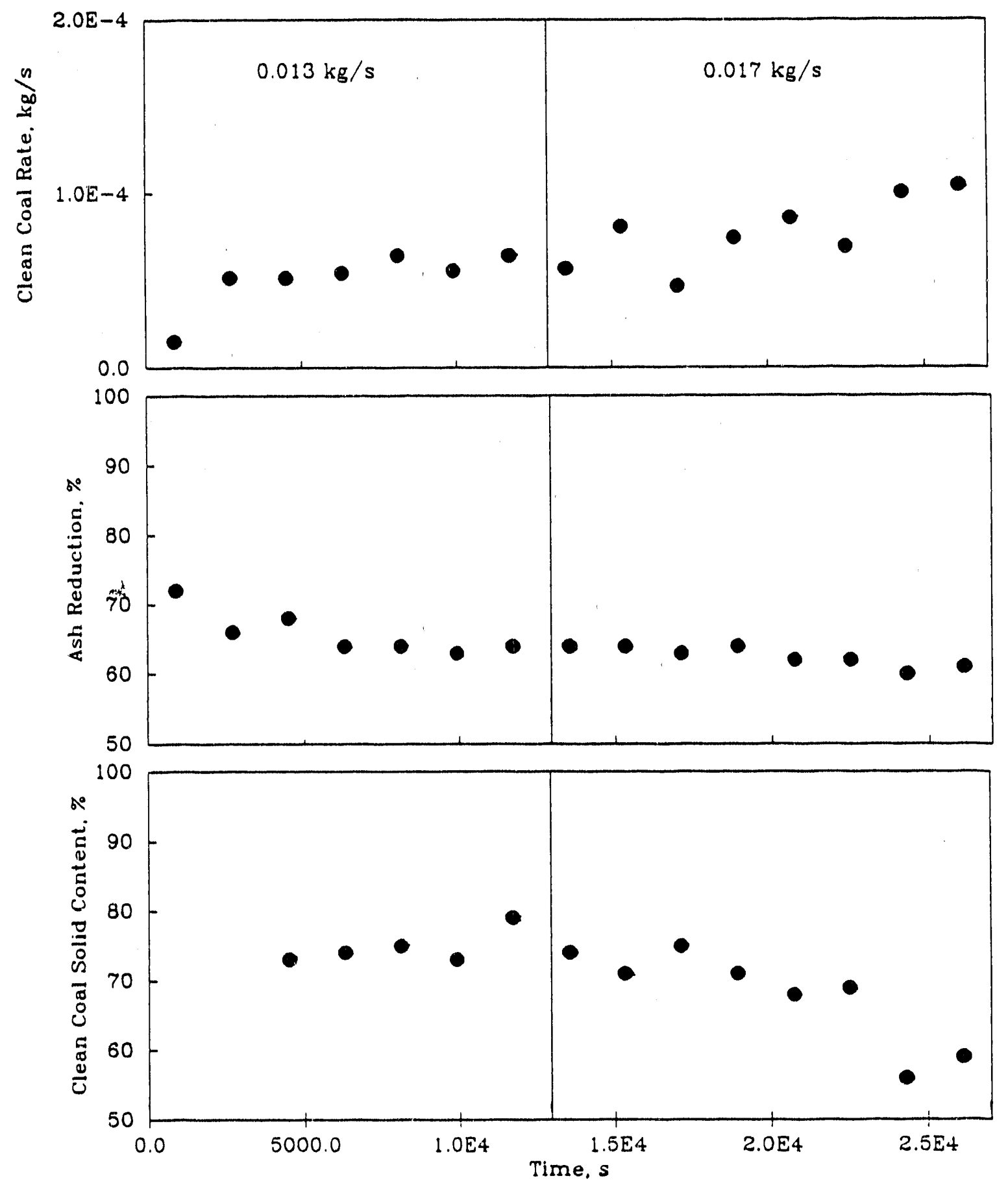

Figure 4.3-1. Results of Test 31 
Table 4.3-2

CRU Tests with Upper Freeport Coal (coal \#3)

Coal Feed Rate $=0.00017 \mathrm{~kg} / \mathrm{s}(1.4 \mathrm{lb} / \mathrm{hr})$

\begin{tabular}{|c|c|c|c|c|c|c|}
\hline \multirow{2}{*}{$\begin{array}{c}\text { Test } \\
\text { No. }\end{array}$} & \multicolumn{2}{|c|}{ Liquid $\mathrm{CO}_{2}$} & \multicolumn{4}{c|}{ Clean Coal } \\
\cline { 2 - 7 } & $\begin{array}{c}\text { Injection } \\
\text { m below } \\
\text { cone top }\end{array}$ & $\begin{array}{c}\text { Flowrate } \\
\mathrm{kg} / \mathrm{s}\end{array}$ & $\begin{array}{c}\text { Heating } \\
\text { Value } \\
\text { Recovery* } \\
\%\end{array}$ & $\begin{array}{c}\text { Solid } \\
\text { Content } \\
\%\end{array}$ & $\begin{array}{c}\text { Ash } \\
\text { Reduction } \\
\%\end{array}$ & $\begin{array}{c}\text { Pyritic } \\
\text { Sulfur } \\
\text { Reduction } \\
\%\end{array}$ \\
\hline \hline 31 & 1.11 & 0.013 & 35 & 75 & 71.8 & 76.8 \\
31 & 0.016 & 44 & 70 & 71.1 & 76.8 \\
34 & & 0.020 & 48 & 61 & 77.5 & 78.5 \\
\hline 37 & 0.81 & 0.013 & 58 & 69 & 74.0 & 79.2 \\
36 & 0.016 & 69 & 65 & 71.8 & 76.2 \\
34 & 0.020 & 63 & 64 & 77.5 & 78.0 \\
\hline \hline
\end{tabular}

* Average over duration of run

Further investigation of the aging effect on slurry samples showed that the contact angles obtained from samples taken immediately after wet grinding and two days after wet grinding remain above 90 degrees (i.e., the coal was hydrophobic) as indicated in Table 4.3-3. The contact angle decreased sharply after 3 days, and a zero reading was registered after 6 days (i.e., the coal was completely hydrophilic). These results strongly suggest that CRU tests should be carried out within two days of preparing the feed slurry in order to obtain meaningful and reproducible results. The alteration in surface property of the coal is thus an important variable affecting the process performance. The improved results obtained in Tests 31-37 could be attributed not only to better operating procedures but also to the fact that freshly ground hydrophobic coal was utilized. 
Table 4.3-3

Contact Angle Results for Upper Freeport Coal Samples

\begin{tabular}{|c|c|}
\hline $\begin{array}{c}\text { Days After } \\
\text { Slurry } \\
\text { Preparation }\end{array}$ & $\begin{array}{c}\text { Advancing } \\
\text { Contact Angle } \\
\text { (degrees) }\end{array}$ \\
\hline \hline 0 & 119 \\
1 & 96 \\
2 & 104 \\
3 & 49 \\
6 & 0 \\
\hline
\end{tabular}

For experiments conducted after installing the premixing tank, Upper Freeport coal (coal \#3) with an ash content of $16.6 \%$ and a sulfur content of $2.6 \%$ was used. A coal feed rate of $0.00016 \mathrm{~kg} / \mathrm{s}(1.3 \mathrm{lb} / \mathrm{hr})$ and a slurry concentration of $5 \%$ were used in these tests. A mixing speed of $168 \mathrm{rad} / \mathrm{s}$ (1600 rpm) in the premixing tank and $84 \mathrm{rad} / \mathrm{s}(800 \mathrm{rpm})$ in the separation column was utilized.

The effects of the liquid $\mathrm{CO}_{2}$ injection rate into the separation column, as well as the influence of the slurry injection point, were investigated. Table 4.3-4 shows the results of these tests.

Table 4.3-4 shows the importance of the liquid $\mathrm{CO}_{2}$ injection rate into the separation column. In both cases, for slurry injection points of 0.30 and $0.41 \mathrm{~m}$ (12 and 16 inches), there is a linear relationship between the yield and the rate of liquid $\mathrm{CO}_{2}$ injected in the separation column. In the experiments in which the slurry is injected above the interface at $0.30 \mathrm{~m}$ (12 inches) below the cone top, the effect of the liquid $\mathrm{CO}_{2}$ rate on the yield is more pronounced than in the case of slurry injection below the interface. Table 4.3-4 shows that under this condition, a heating value recovery as high as $80 \%$ was achieved with good separation characteristics when the liquid $\mathrm{CO}_{2}$ flowrate was maintained at $0.005 \mathrm{~kg} / \mathrm{s}(: 500 \mathrm{~g} / \mathrm{min})$ in both the premixing tank and the separation column. When the slurry is injected above the interface, the 
liquid $\mathrm{CO}_{2}$ injected directly into the separation column is the only stream available for capturing agglomerates in the aqueous phase. In the case of the injection below the interface, the liquid $\mathrm{CO}_{2}$ carried from the premixing tank also contributes to transferring agglomerates across the interface. In the latter case then, the liquid $\mathrm{CO}_{2}$ injected into the column does not play a role as critical as in the case of injection above the interface. The above data also indicate that the water content of the product is higher when the slurry is injected below the interface. The additional water antrainment is caused by the carryover in 1 iquid $\mathrm{CO}_{2}$ from the premixing tank.

Table 4.3-4

Effect of the Liquid $\mathrm{CO}_{2}$ Injection

Rate into the Separation Column and

the Slurry Injection Point Position

Interface Position: $0.36 \mathrm{~m}$ (14 inches) below top of cone

\begin{tabular}{|c|c|c|c|c|c|c|}
\hline \multirow{2}{*}{$\begin{array}{l}\text { Slurry } \\
\text { Injection } \\
\text { Point, } \\
\text { m below } \\
\text { cone top }\end{array}$} & \multicolumn{2}{|c|}{$\begin{array}{l}\text { Liquid } \mathrm{CO}^{2} \\
\text { Flowrate, } \mathrm{kg} / \mathrm{s}\end{array}$} & \multicolumn{4}{|c|}{ Clean Coal } \\
\hline & $\begin{array}{c}\text { Mixing } \\
\text { Tank }\end{array}$ & $\begin{array}{l}\text { Separation } \\
\text { Column }\end{array}$ & $\begin{array}{c}\text { Heating } \\
\text { Value } \\
\text { Recovery } \\
\%\end{array}$ & $\begin{array}{l}\text { Solid } \\
\text { Content } \\
\%\end{array}$ & $\begin{array}{c}\text { Ash } \\
\text { Reduction } \\
\%\end{array}$ & $\begin{array}{l}\text { Pyritic } \\
\text { Sulfur } \\
\text { Reduction } \\
\%\end{array}$ \\
\hline 0.30 & 0.005 & $\begin{array}{l}0.0016 \\
0.0033 \\
0.0050\end{array}$ & $\begin{array}{l}22 \\
48 \\
80\end{array}$ & $\begin{array}{l}52 \\
57 \\
57\end{array}$ & $\begin{array}{l}66.2 \\
66.2 \\
65.6\end{array}$ & $\begin{array}{l}77.1 \\
77.1 \\
77.0\end{array}$ \\
\hline 0.41 & 0.0033 & $\begin{array}{l}0.0016 \\
0.0033 \\
0.0050\end{array}$ & $\begin{array}{l}47 \\
61 \\
73\end{array}$ & $\begin{array}{l}48 \\
53 \\
44\end{array}$ & $\begin{array}{l}65.6 \\
63.8 \\
62.6\end{array}$ & $\begin{array}{l}77.0 \\
76.2 \\
78.5\end{array}$ \\
\hline
\end{tabular}

The effect of the liquid $\mathrm{CO}_{2}$ injection rate into the premixing tank on the process results is shown in Table 4.3-5.

From the data in Table 4.3-5, it can be observed that conditioning of the slurry in the premixing tank increases the product recovery (also compared 
with results in Table 4.3-2). The results show that only $0.83 \times 10-3 \mathrm{~kg} / \mathrm{s}$ (50 $\mathrm{g} / \mathrm{min}$ ) of liquid $\mathrm{CO}_{2}$ are needed in the premixing tank to form agglomerates, and that a larger amount of liquid $\mathrm{CO}_{2}$ does not significantly influence the process performance.

Table 4.3-5

Effect of Liquid $\mathrm{CO}_{2}$ Injection into the Premixing Tank

Separation Column Liquid $\mathrm{CO}_{2}$ Flowrate: $0.005 \mathrm{~kg} / \mathrm{s}$

\begin{tabular}{|c|c|c|c|c|}
\hline \multirow{2}{*}{$\begin{array}{c}\text { Premixing Tank } \\
\text { Liquid } \mathrm{CO}_{2} \\
\text { Flowrate } \\
\mathrm{kg} / \mathrm{s} \times 10-3\end{array}$} & $\begin{array}{c}\text { Heating } \\
\text { Value } \\
\text { Recovery } \\
\%\end{array}$ & $\begin{array}{c}\text { Solid } \\
\text { Content } \\
\%\end{array}$ & $\begin{array}{c}\text { Ash } \\
\text { Reduction } \\
\%\end{array}$ & $\begin{array}{c}\text { Pyritic } \\
\text { Sulfur } \\
\text { Reduction } \\
\%\end{array}$ \\
\hline \hline 0.0 & 44 & 67 & 72.9 & 75.0 \\
0.83 & 72 & 61 & 70.5 & 74.4 \\
1.66 & 77 & 62 & 66.3 & 73.8 \\
5.0 & 68 & 61 & 66.3 & 73.8 \\
\hline
\end{tabular}

The influence of the liquid $\mathrm{CO}_{2}$-water interface position in the separation column on the process performance was studied by conducting tests with the interface at $0.36,0.41$, and $0.46 \mathrm{~m}(14,16$, and 18 inches) below the top of the cone. These tests were carried out using a liquid $\mathrm{CO}_{2}$ ilowrate of $0.0083 \mathrm{~kg} / \mathrm{s}(50 \mathrm{~g} / \mathrm{min})$ in the mixing tank and 0.083 $\mathrm{kg} / \mathrm{s}(500 \mathrm{~g} / \mathrm{min})$ in the separation column. The slurry injection point was kept at 12 inches below the cone top. The resilts of these experiments are shown in Table 4.3-6. They indi:ate that a lower interface translates into a higher solid content in the product but at the expense of a lower product recovery. 
Table 4.3-6

Effect of the Interface Position

\begin{tabular}{|c|c|c|c|c|}
\hline \multirow{2}{*}{$\begin{array}{c}\text { Interface } \\
\text { Position, } \\
\text { m below } \\
\text { cone top }\end{array}$} & $\begin{array}{c}\text { Heating } \\
\text { Value } \\
\text { Recovery } \\
\%\end{array}$ & $\begin{array}{c}\text { Solid } \\
\text { Content } \\
\%\end{array}$ & $\begin{array}{c}\text { Ash } \\
\text { Reduction } \\
\%\end{array}$ & $\begin{array}{c}\text { Pyritic } \\
\text { Sulfur } \\
\text { Reduct ion } \\
\%\end{array}$ \\
\hline \hline 0.36 & 69 & 49 & 66.3 & 72.6 \\
0.41 & 64 & 61 & 69.3 & 73.8 \\
0.46 & 57 & 69 & 72.3 & 74.4 \\
\hline
\end{tabular}

The effect of the mixing speed in the premixing tank was studied in experiments carried out with the interface located $0.46 \mathrm{~m}$ (18 inches) below the top of the cone. The feed coal rate was $0.00017 \mathrm{~kg} / \mathrm{s}(1.4$ $\mathrm{lb} / \mathrm{hr}$ ) and the slurry injection point was located $0.30 \mathrm{~m}$ (12 inches) below the top of the cone. The liquid $\mathrm{CO}_{2}$ injection rate into the mixing tank was $0.00083 \mathrm{~kg} / \mathrm{s}(50 \mathrm{~g} / \mathrm{min})$ and $0.0083 \mathrm{~kg} / \mathrm{s}(500 \mathrm{~g} / \mathrm{min})$ in the separation column. The results of ihese experiments are given in Table 4.3-7. The results show that the product recovery improves with lower mixing speed in the premixing tank with only a minor decrease in the product quality.

Table 4.3-7

Effect of the Premixing Tank Mixing Speed

\begin{tabular}{|c|c|c|c|c|}
\hline \multirow[b]{2}{*}{$\begin{array}{l}\text { Premixing } \\
\text { Tank } \\
\text { Mixing } \\
\text { Speed, } \\
\text { rad/s }\end{array}$} & \multicolumn{4}{|c|}{ Clean Coal } \\
\hline & $\begin{array}{c}\text { Heating } \\
\text { Value } \\
\text { Recovery } \\
\%\end{array}$ & $\begin{array}{c}\text { Solid } \\
\text { Content } \\
\%\end{array}$ & $\begin{array}{c}\text { Ash } \\
\text { Reduction } \\
\%\end{array}$ & $\begin{array}{c}\text { Pyritic } \\
\text { Sulfur } \\
\text { Reduction } \\
\qquad \%\end{array}$ \\
\hline $\begin{array}{l}125 \\
166 \\
210\end{array}$ & $\begin{array}{l}67 \\
57 \\
46\end{array}$ & $\begin{array}{l}69 \\
69 \\
72\end{array}$ & $\begin{array}{l}69.3 \\
72.3 \\
73.5\end{array}$ & $\begin{array}{l}73.8 \\
74.4 \\
75.0\end{array}$ \\
\hline
\end{tabular}


The effect of the liquid $\mathrm{CO}_{2}$ distribution was studied using a total liquid $\mathrm{CO}_{2}$ flowrate of $0.015 \mathrm{~kg} / \mathrm{s}(900 \mathrm{~g} / \mathrm{min})$. The mixing speed was kept at $63 \mathrm{rad} / \mathrm{s}(600 \mathrm{rpm})$ in the separation column and at $125 \mathrm{rad} / \mathrm{s}$ (1200 $\mathrm{rpm}$ ) in the premixing tank. The interface was located at $0.36 \mathrm{~m}$ (14 inches) below the top of the cone. Table 4.3-8 illustrates that excellent heating value recoveries close to $80 \%$ were achieved at a flowrate of 0.005 $\mathrm{kg} / \mathrm{s}(300 \mathrm{~g} / \mathrm{min})$ in the premixer. The heating value recovery increased steadily as the flowrate in the premixing tank was increased.

Experiments with Upper Freeport coal (coal \#3) have also been conducted at higher capacities of $0.00076 \mathrm{~kg} / \mathrm{s}$ and $0.0012 \mathrm{~kg} / \mathrm{s}(6 \mathrm{lb} / \mathrm{hr}$ and $10 \mathrm{lb} / \mathrm{hr})$. The system operated smoothly at its rated capacity of $0.0012 \mathrm{~kg} / \mathrm{s}$ (10 $\mathrm{lb} / \mathrm{hr})$.

Table 4.3-8

Effect of Liquid $\mathrm{CO}_{2}$ Distribution

\begin{tabular}{|c|c|c|c|c|c|}
\hline \multicolumn{2}{|c|}{$\begin{array}{l}\text { Liquid } \mathrm{CO}_{2} \text { Flowrate } \\
\mathrm{kg} / \mathrm{s} \times 10-3\end{array}$} & \multicolumn{4}{|c|}{ Clean Coal } \\
\hline $\begin{array}{l}\text { Premixing } \\
\text { Tank }\end{array}$ & $\begin{array}{l}\text { Separation } \\
\text { Column }\end{array}$ & $\begin{array}{c}\text { Heating } \\
\text { Value } \\
\text { Recovery } \\
\%\end{array}$ & $\begin{array}{c}\text { Solid } \\
\text { Content } \\
\%\end{array}$ & $\begin{array}{c}\text { Ash } \\
\text { Reduction } \\
\%\end{array}$ & $\begin{array}{c}\text { Pyritic } \\
\text { Sulfur } \\
\text { Reduction } \\
\%\end{array}$ \\
\hline $\begin{array}{l}1.66 \\
3.33 \\
5.00\end{array}$ & $\begin{array}{l}13.3 \\
11.6 \\
10.0\end{array}$ & $\begin{array}{l}57 \\
71 \\
78\end{array}$ & $\begin{array}{l}63 \\
58 \\
63\end{array}$ & $\begin{array}{l}66.3 \\
65.7 \\
67.5\end{array}$ & $\begin{array}{l}72.6 \\
72.6 \\
74.4\end{array}$ \\
\hline
\end{tabular}

Results with Upper Freeport coal (coal \#3) were compared with data from the washability analysis of -74 micron size samples, and they are presented in Figure $4.3-2$ for a feed rate of $0.00017 \mathrm{~kg} / \mathrm{s}(1.4 \mathrm{lb} / \mathrm{hr})$. It can be observed that the CRU results were close to the washability curve. It must be pointed out that the washability curve was obtained for a batch of coal \#3 with a feed ash content of $13.5 \%$, while the CRU experimental 


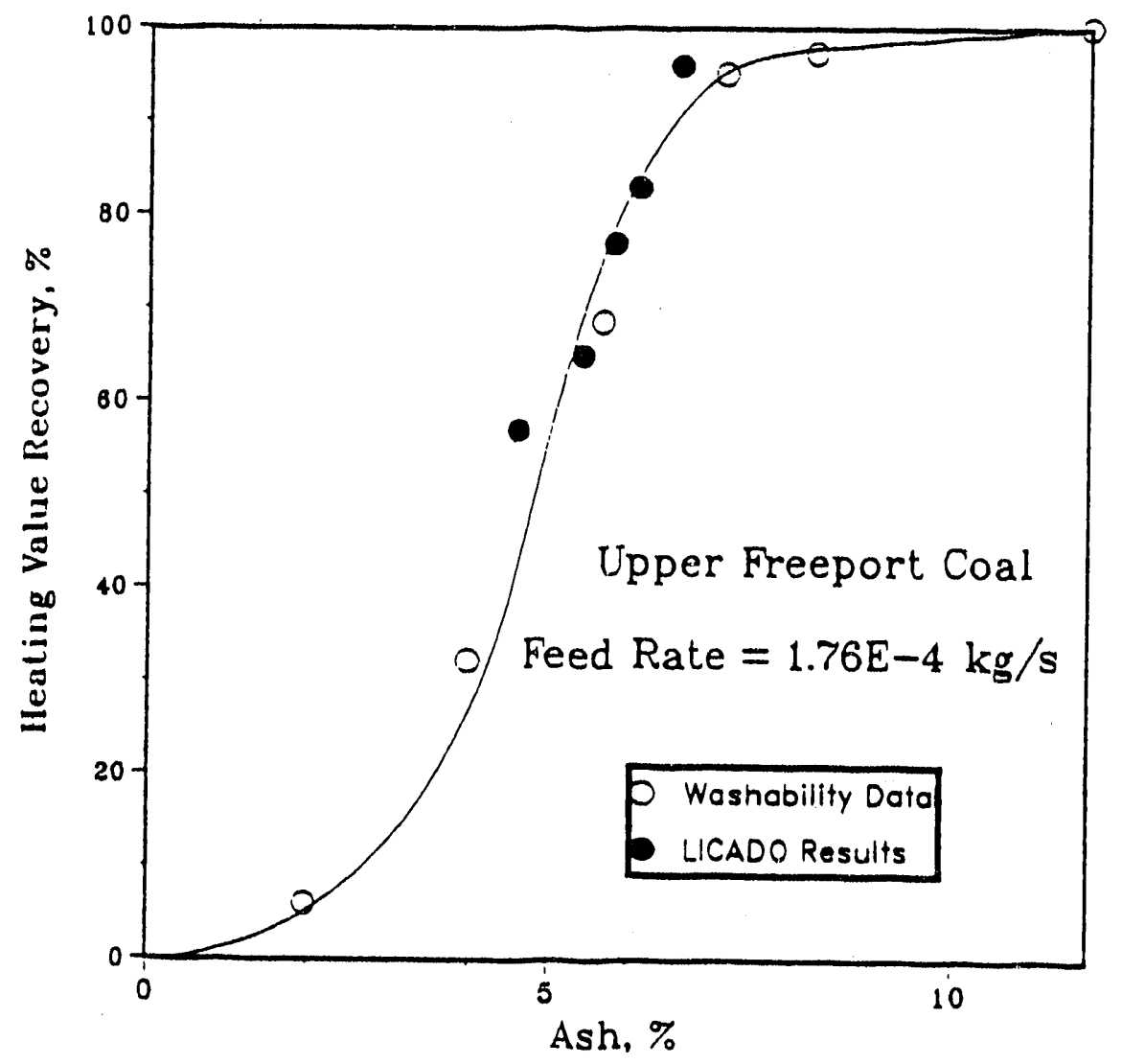

Figure 4.3-2. Comparison with Washability Curve for $1.76 \times 10^{-4} \mathrm{~kg} / \mathrm{s}(1.4 \mathrm{lb} / \mathrm{hr})$ with Upper Freeport Coal 
results were obtained with another portion of the same sample exhibiting an ash content of $16.6 \%$ in the feed. In other words, the washability curve was obtained for a cleaner feed coal. The inherent differences in the results due to this factor must also be considered. A similar plot was generated for a feed rate of $0.00038 \mathrm{~kg} / \mathrm{s}(3 \mathrm{lb} / \mathrm{hr})$, as shown in Figure 4.3-3. The variation of pyritic sulfur in the product with heating value recovery for Upper Freeport coal is represented in Figure 4.3-4.

In Figure 4.3-5, the coal feed rate, up to $0.0012 \mathrm{~kg} / \mathrm{s}(10 \mathrm{lb} / \mathrm{hr})$, has been plotted as a function of heating value recovery and ash reduction for coal \#3. The range of experimental results for various operating conditions at each capacity is represented in the graph in the form of bars. It can be observed that heating value recoveries are in the $80 \%$ range for capacities up to $0.00038 \mathrm{~kg} / \mathrm{s}(3 \mathrm{lb} / \mathrm{hr})$, but they decrease at higher feed rates. The effect on ash reduction is not so pronounced at higher feed rates, and the ash reduction remained in the $60-70 \%$ range. After completing an extensive number of tests with Upper Freeport coal (approximately 80 experiments in the (RU), two other coals were also tested in the CRU, utilizing the optimum values of parameters observed for Upper Freeport coal as a starting point in the investigation. Limited number of tests were carried out with Pittsburgh No. 8 coal and Illinois No. 6 coal.

The results obtained in processing Pittsburgh No. 8 coal in the CRU are shown in Figure 4.3-6, and comparison is made with the washability curve at the same particle size $(-74$ microns $)$. The results shown in Figure 4.3-6 were for a capacity of $0.00017 \mathrm{~kg} / \mathrm{s}(1.4 \mathrm{lb} / \mathrm{hr})$. The graph reveals that the separation obtained is better than the washability curve for this particle size. Improved results were obtained by maintaining the interface position at $0.3 \mathrm{~m}$ (12 inches) below the top of the cone. Tests performed at higher feed rates again resulted in a decrease in the heating value recovery. A limited number of experiments were also conducted with Illinois No. 6 coal (coal \#8). Figure 4.3-7 compares the experimental results at a capacity of $0.00017 \mathrm{~kg} / \mathrm{s}(1.4 \mathrm{lb} / \mathrm{hr})$ with the washability 


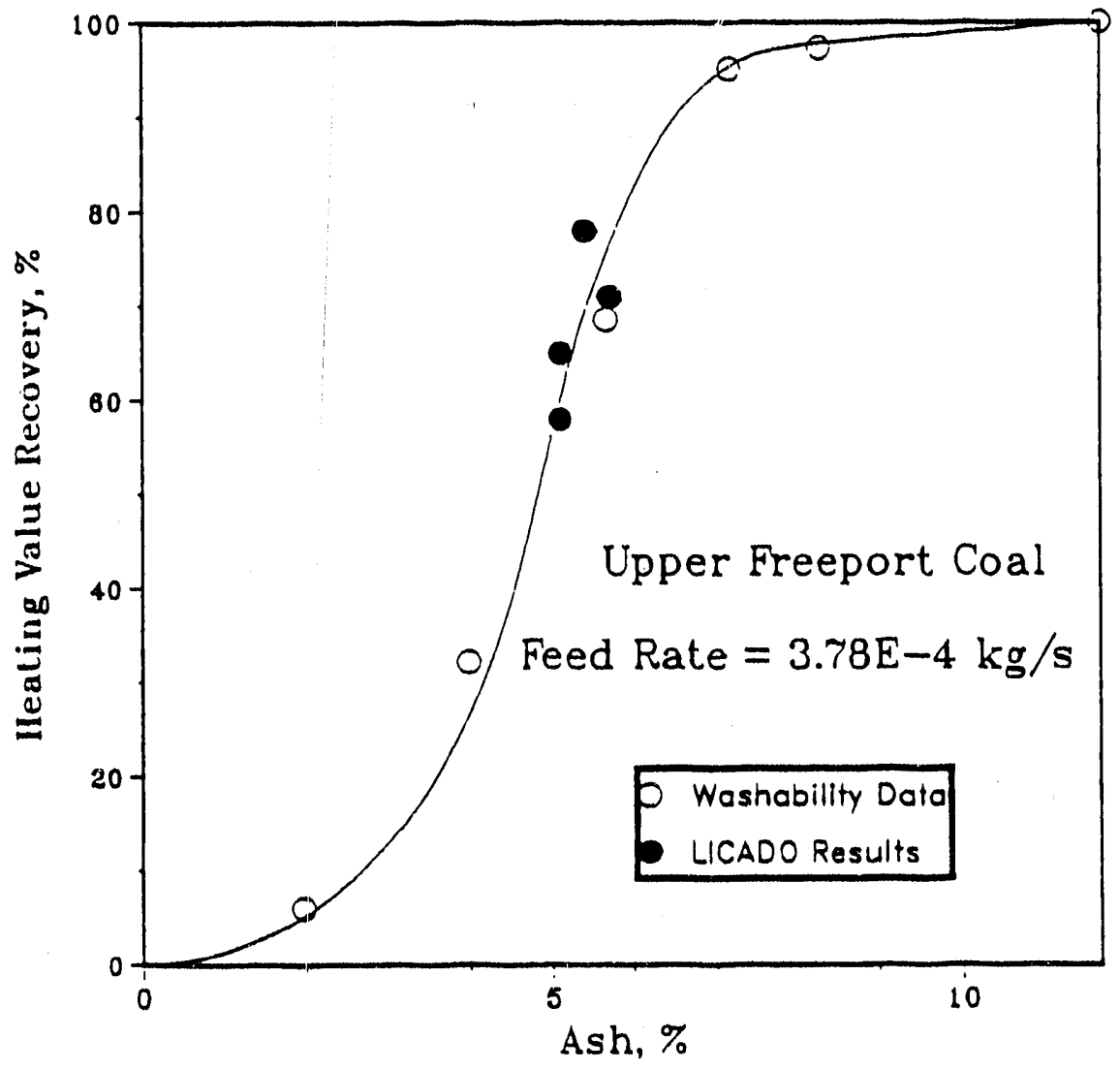

Figure 4.3-3. Comparison with Washability Curve for $3.78 \times 10^{-4} \mathrm{~kg} / \mathrm{s}(3 \mathrm{lb} / \mathrm{hr})$ Tests with Upper Freeport Coal 


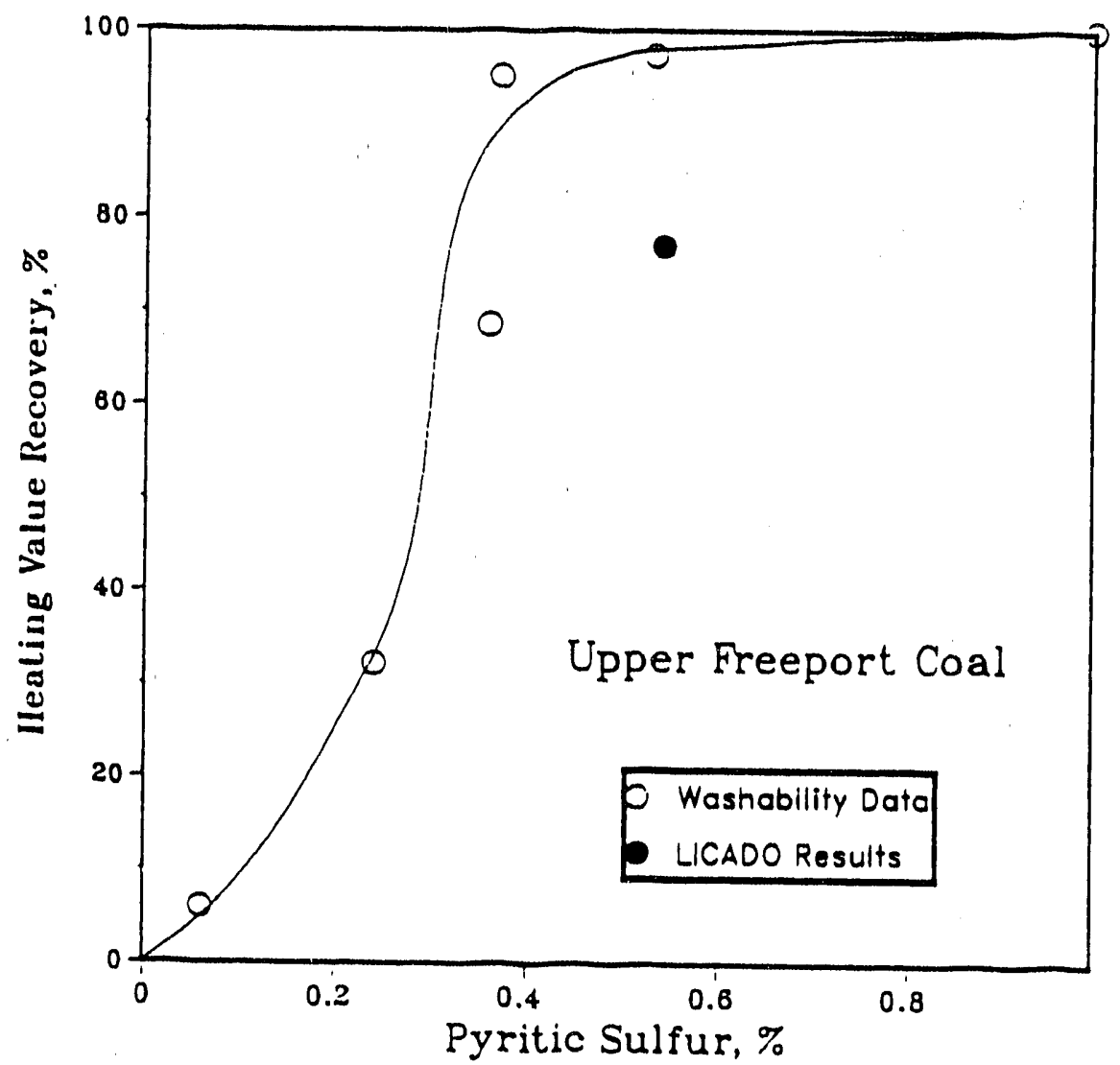

Figure 4.3-4. Pyritic Sulfur in Product as Function of Heating Value Recovery for Upper Freeport Coal 


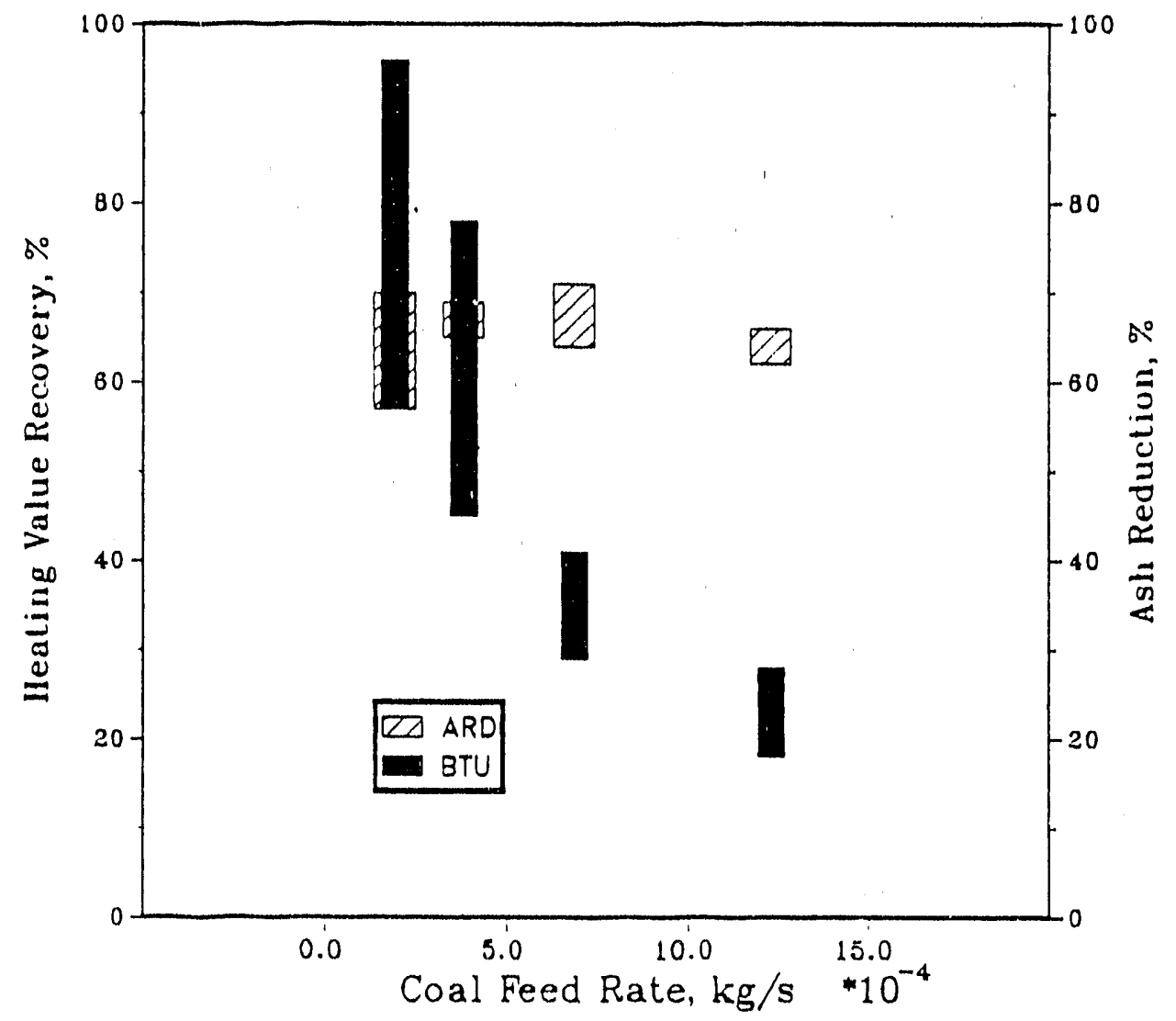

Figure 4.3-5. Effect of Coal Feed Rate on Process Performance 


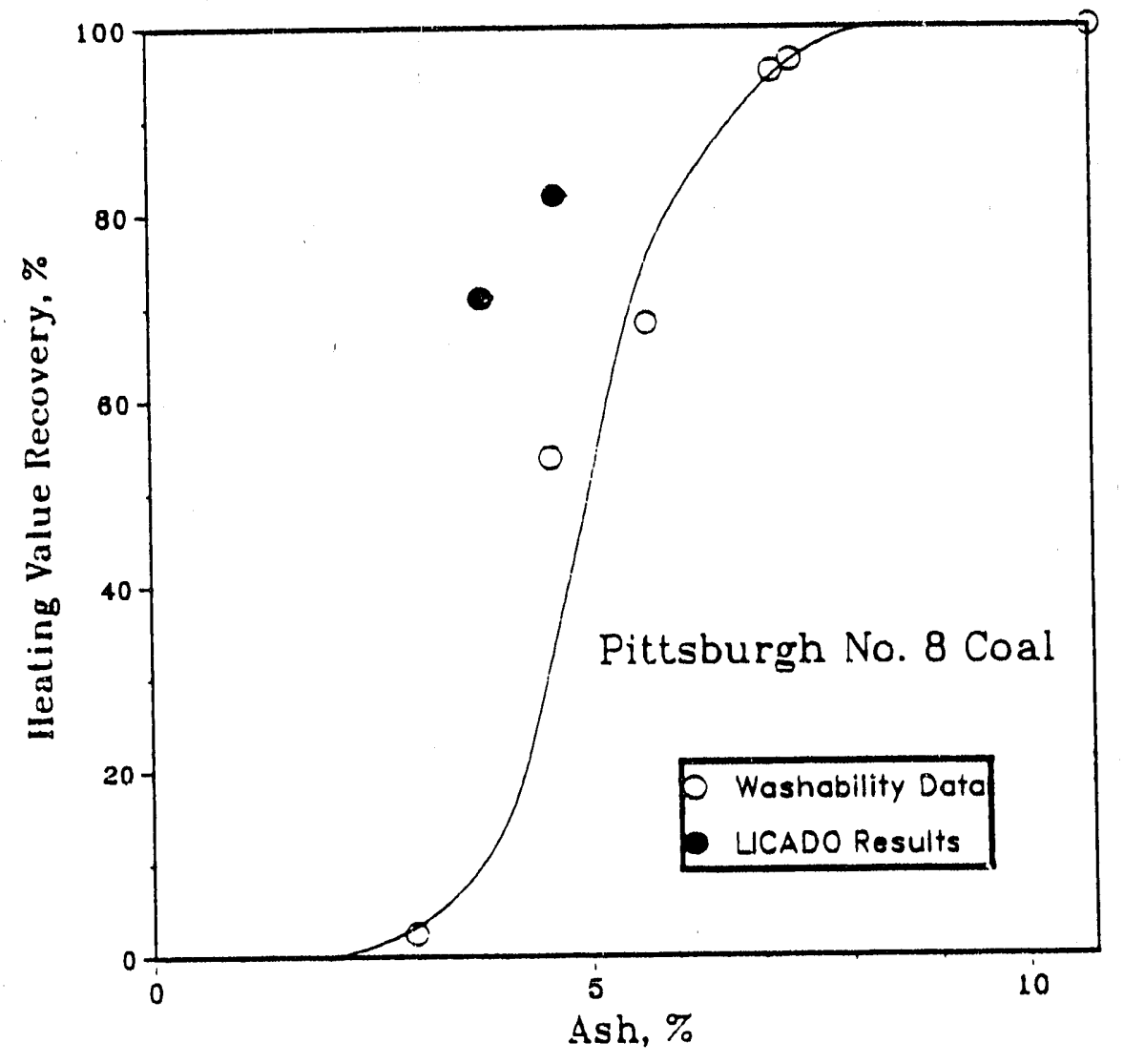

Figure 4.3-6. Comparison with Washability Curve for Pittsburgh No. 8 Coal 


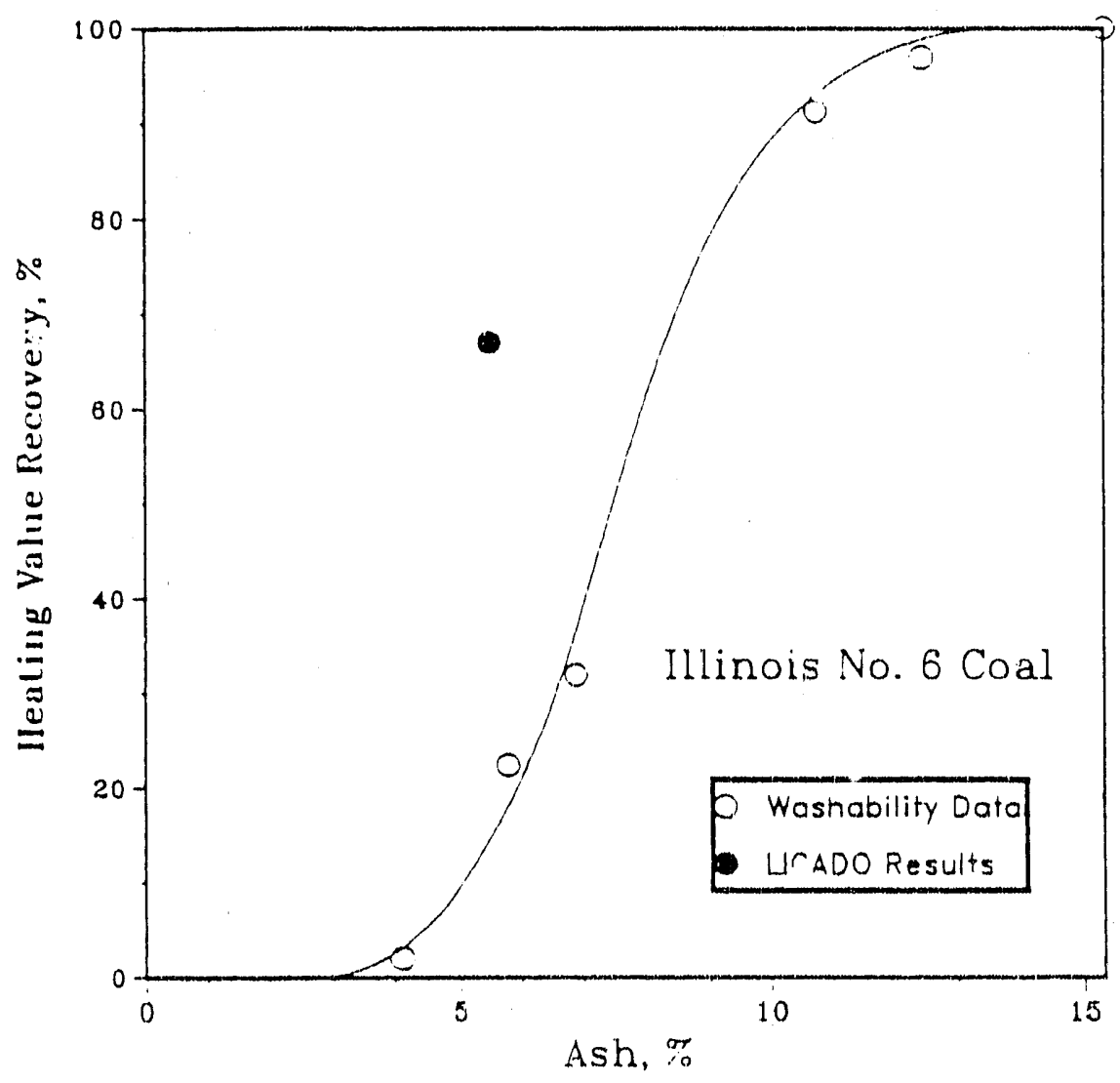

Figure 4.3-7. Comparison with Washability Curve for Illinois No. 6 Coal 
curve for the .74 micron sample. Again, the performance of the LICADO process appears to be superior to that indicated by the washability analysis. Improved heating value recovery as well as separation were observed when the interface position was raised to $0.25 \mathrm{~m}$ (10 in) below the top of the cone.

The results indicate that for the present column design (including column dimensions and mixer), the CRU can achieve excellent process performance up to $0.00038 \mathrm{~kg} / \mathrm{s}(3 \mathrm{lb} / \mathrm{hr})$. Mechanisal modifications are required to upgrade the performance characteristics of CRU for larger throughputs.

Larger $\mathrm{CO}_{2} / \mathrm{coal}$ ratios may be required to obtain improved process performance for throughfits exceeding $3 \mathrm{lb} / \mathrm{hr}$. Minor modifications in the design of the clean coal filter will permit the handing of larger volumes of liquid $\mathrm{CO}_{?}$.

In conclusion, the integrated LICADO process was successfully developed by constructing and operating the Continuous Research Unit up to its capacity of $10 \mathrm{lb} / \mathrm{hi}^{-}$. The unit was operated smoothly in tests lasting up to 14 hrs. The different units in the CRU (i.e., the separation column, filter, premixing tank, and the various control schemes) functioned well in conjunction, and troublefree operation was achieved. The effects of various process parameters such as mixing speed, flowrate of $\mathrm{CO}_{2}$ in premixer and separation column, and interface and slurry injection positions were investigated. The findings obtained in the CRU can be used to establish design criteria for the development of a 1 ton/hr proof-of-concept plant based on the 1.1CAno process. 


\subsection{CONTINUOUS UNIT}

The objective of this task was to design and develop a Continuous Unit to process up to $0.006 \mathrm{~kg} / \mathrm{s}(50 \mathrm{lb} / \mathrm{hr})$ of feed coal by the LICADO process.

\subsection{Equipment}

To upgrade the Continuous Research Unit to process up to $0.006 \mathrm{~kg} / \mathrm{s}$ (50 $1 \mathrm{~b} / \mathrm{hr}$ ) of feed coa?, a new separation column was designed and fabricated at the University of Pittsburgh. The separation column is shown in Figure 5.1-1. It has a diameter or about $0.15 \mathrm{~m}$ ( 6 inches) I.D. and a height of $0.93 \mathrm{~m}$ (37 inches). A conical section will be added to the top of this unit. Owing to time limitations, the test program was redirected; and the experimental program for the $0.006 \mathrm{~kg} / \mathrm{s}(50 \mathrm{lb} / \mathrm{hr})$ tests was not performed. 


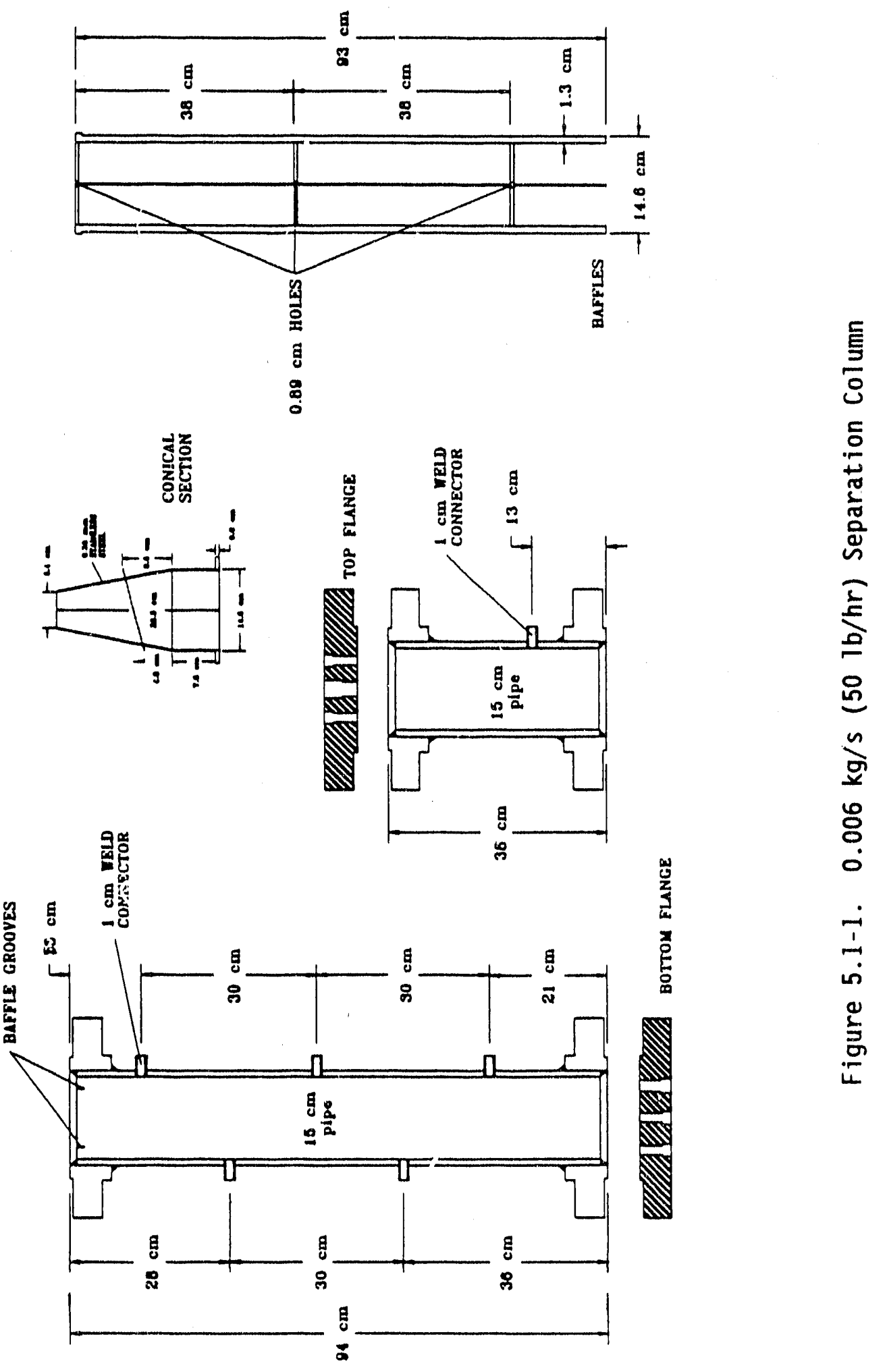




\subsection{SIMULATION MODEL}

A plant simulation model was developed to provide scale-up data for the Proof-of-Concept $\mathrm{Plant}$ and to provide equipment and process information for the commercial plant economic studies.

\subsection{Description of Model}

The plant simulation model (LICADO Plant simulation), LIPS, provides material and energy balances around each of the unit operation's in the LICADO Plant. This model, which is programutu in FORTRAN, is operational on any Personal Computer (PC) having FORTRAN IV software. Two programs are available, LIPSA, which is for Pittsburgh-Bruceton coal, and LIPSB, which is for Upper Freeport coal. The listings for these programs are attached to this report as Appendix $E$ and $F$. Other coals can be modeled simply by using their properties as input to the program.

Input data for LIPS includes the identification of the coal being processed, its composition (ash, moisture, pyritic sulfur, organic sulfur, sulfates), and process separation factors for ash and pyritic sulfur. The desired clean coal production rate for the plant simulation is also specified. Other plant characteristics are also provided as input to the program. These data include coal particle size, feed slurry concentration, residence times in the mixer and separator, separation efficiencies at the filter, cyclone and dewatering unit, solubility of carbon dioxide in the water, solubility of water in the carbon dioxide, and ratio of liquid carbon dioxide flow to slurry flow rate. These plant characteristics for the model were based on the test data obtained from both the batch tests and the experiments with the Continuous Research Unit.

The unit operations for the simulation model are shown in Figure 6.1-1. The power required to grind the coal is calculated using an algorithm 


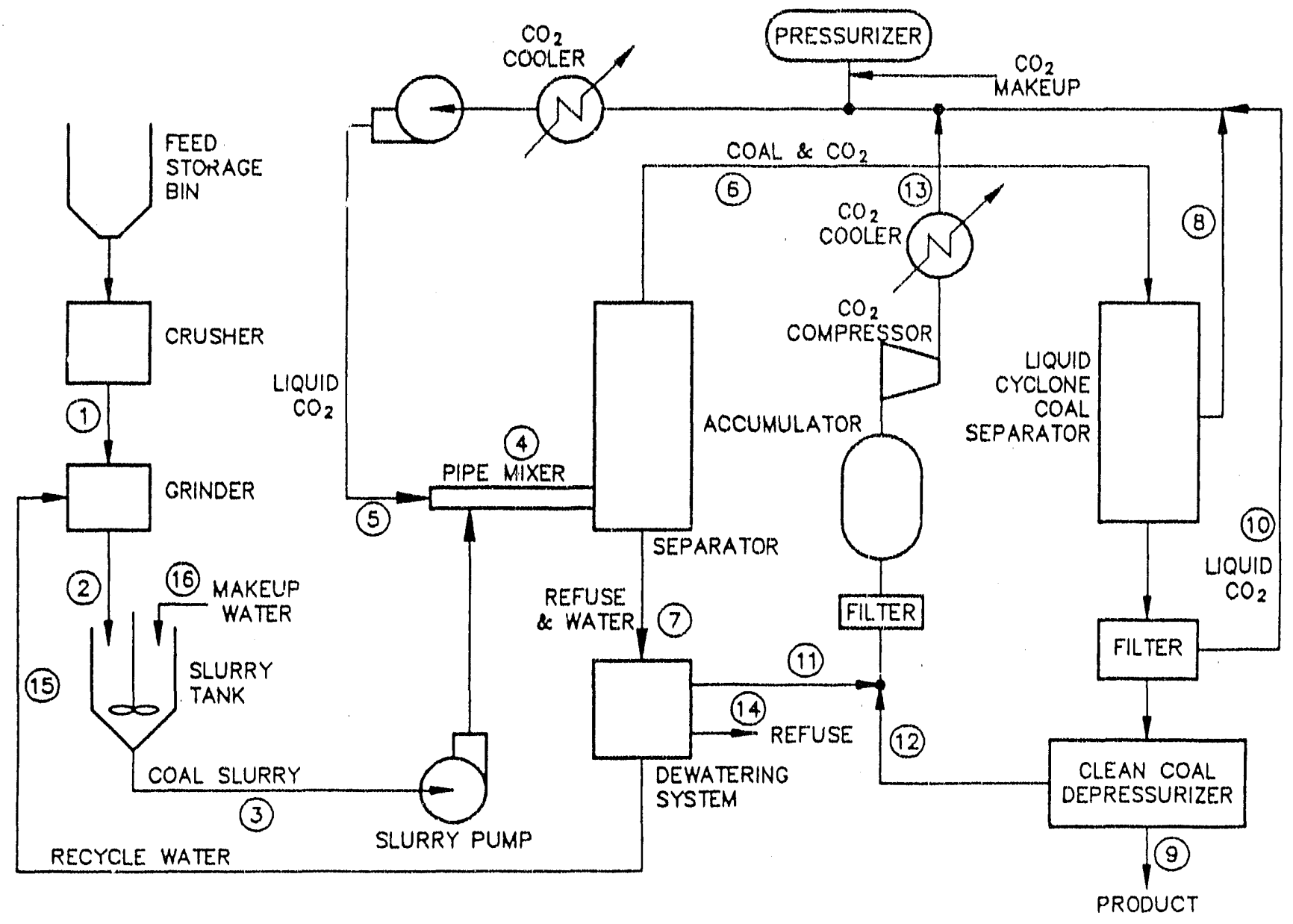

LICADI PLANT SIMULATION

UPPER FREEPURT CQAL

PRDDUCTIIN RATE, LB/HR=2000,0

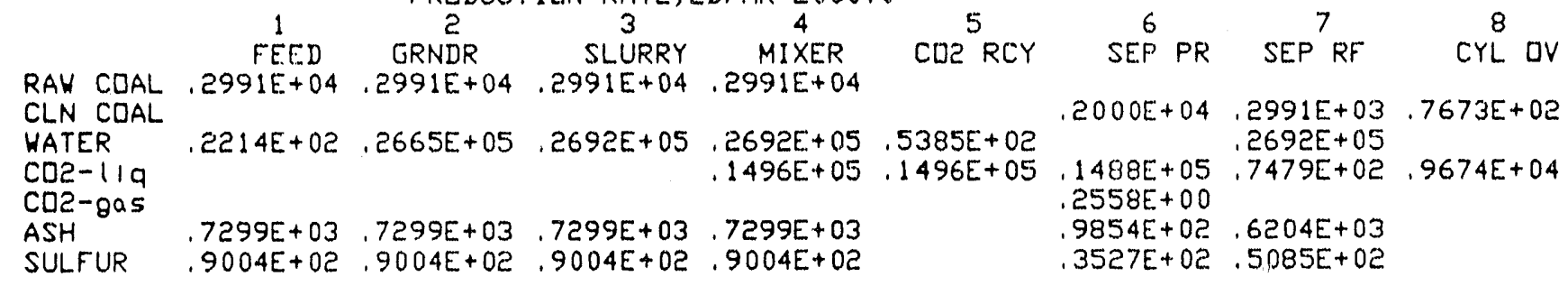

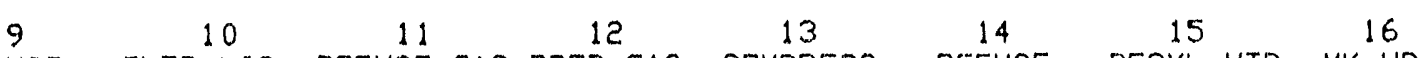
PRDDUCT FLTR LIQ REFUSE GAS PRDD GAS CDMPRESS REFUSE RECYL WTR MK UP WTR

RAW CDAL

CLN CDAL . $2000 E+04.2557 E+01$

WATER $, 9962 E+00,1042 E+02$

CD2-119 $\quad .5209 E+04$

CO2-005 . .2558E+00

ASH $\quad .9854 E+02$

SULFUR , 3527E+ 02

$.2687 E+02.2558 E+00 \begin{array}{ccc}.2872 E+03 \\ .2687 E+03 & .2665 E+05.2697 E+03 \\ & .7404 E+02 \\ & .7479 E+00 \\ & .6204 E+03 \\ & .5085 E+02\end{array}$

CC880608-2F

Figure 6.1-1. Integrated Statepoint Diagram 
based on the final particle size. This algorithm and the supporting data are provider in Appendix $E$. The material balance at the slurry tank provides the makeup water that is required to be added to the recycle water to yield the required solids concentration in the slurry. The slurry pump power is calculated from the slurry flow and pressure differential across this pump.

The mixer and separator are sized to provide the specified residence time in each unit. The wall thicknesses of the shell and the head of each of these units are calculated using the ASME code for Unfired Pressure Vessels. The Mixer and Separator are assumed to be fabricated of stainless steel clad carbon steel. Therefore, the mechanical properties of SA516, Grade 70 carbon steel, were used to calculate the required wall and head thicknesses for the pressure vessel. From the separator, the carbon dioxide/clean coal slurry flows to the cyclone. The cyclone, which is not included in the Continuous Research Unit, has been added to the Proof-of-Concept design as a result of the plant simulation studies. The cyclone removes about $65 \%$ of the liquid carbon dioxide from the carbon dioxide/clean coal stream leaving the separator. Removal of this liquid carbon dioxide reduces the liquid flow through the filter and reduces its size.

The cyclone is modeled using the overflow and underflow distributions recommended by the cyclone manufacturer. Since the small amount of coal entrained in the overflow is recycled to the process, the coal in the liquid carbon dioxide will reach a steady-state concentration; and its effect upon the clean coal production rate can be neglected.

Refuse and water, discharged from the bottom of the separator, enters a dewatering tank, where the liquid is depressurized, the refuse slurry is discharged, and the water is recycled to the wet grinder. The carbon dioxide in solution in the water flashes to vapor when the pressure is released in the dewatering unit. This vapor is recompressed and cooled to a liquid and recycled to the liquid carbon dioxide system. 
The underflow from the cyclone flows to the filter in which the clean coal is separated from the liquid carbon dioxide. The liquid carbon dioxide from the filter flows to the liquid carbon dioxide system, while the clean coal passes to the clean coal depressurizer, where the clean coal is discharged and the absorbed liquid carbon dioxide flashes to vapor upon depressurization. This carbon dioxide vapor joins the carbon dioxide vapor released from the water and is liquefied by the compressor/cooler.

The output from LIPS is displayed in two arrargements. In the first, the output is presented in tabular form, together with the input and plant characteristics. A sample of this output is illustrated in the Appendix. In order to provide a graphic output that is visually linked to the plant flow diagram, the output file from LIPS can be transferred to the CADD system in which the plant flow diagram is programmed. The output file from LIPS is stored on a disk, and this file can be 1 ad into the CADD system, which then provides a plant flow diagram integrated with the state point data obtained from the LIPS output file. Figure 6.1-1 is an example of the plant flow diagram incorporating the LIPS output data using this method. The output data are presented in FORTRAN exponential notation for compactness and uniformity of the tables. In this notation, the decimal at the left is multiplied by 10 raised to the power indicated after the "E". The numbers in the column headings refer to the flow streams in the flow diagram.

In order to define the complete process, both the integrated statepoint/ flow diagram and the tabular process summary must be used. The tabular process summary provides information specifying the coal characteristics and the process constraints and assumptions. The assumptions and constraints include constraints such as the $\mathrm{CO}_{2}$-to-coal slurry ratio, residence time in the mixer and separator, for example, and assumptions such as separation efficiencies at the various unit operations. The assumptions are based on experimental data from the batch tests and the Continuous Research Unit. 
The process data, constraints and assumptions made for this analysis are:

Coal Properties:

Fract. Ash

Fract. Moisture

Fract. Pyrite Sulfur

Fract. Organic Sulfur

Fract. Sulfates
0.244 (dimensionless)

0.0074 (dimensiontess)

0.0104 (dimensionless)

0.0039 (dimensionless)

0.0001 (dimensionless)

Process Data:

Clean Coal Production Rate

Coal Heating Value

Coal Particle Size

STurry Concentration

Mixer Residence Time

Separator Residence Time

Fract. Ash Removed

Fract. Pyrite Removed

Fract. Water in $\mathrm{CO}_{2}$

Fract. $\mathrm{CO}_{2}$ in Water

System pressure

$\mathrm{CO}_{2}$ to Slurry Ratio

Fract. Coal Separated by Filter

Fract. Water in $\mathrm{CO}_{2}$
2,000 $\mathrm{lb} / \mathrm{hr}$

$13,000 \mathrm{Btu} / 1 \mathrm{~b}$

73 microns

0.10 (dimensionless)

$100 \mathrm{sec}$

$500 \mathrm{sec}$

0.90 (dimensionless)

0.90 (dimensionless)

0.002 (dimensionless)

0.005 (dimensionless)

850 psia

0.50 (dimensionless)

0.999 (dimensionless)

0.002 (dimensionless) 


\subsection{Results}

\subsubsection{Plant Studies}

Plants with cleis coal capacities of 1 -ton $/ \mathrm{hr}$ ( 0.91 metric ton $/ \mathrm{hr}), 50$ tons $/ \mathrm{hr}$ (45 metric tons $/ \mathrm{hr}$ ), and 200 tons $/ \mathrm{hr}$ (181 metric tons $/ \mathrm{hr}$ ) were analyzed with LIPSA (for Pittsburgh Bruceton coal) and LIPSB (for Upper Freeport coal). These analyses were used for the design of the Proof-ofConcept Plant ( 0.91 metric ton/hr) and for economic analyses of 45 and 181 metric ton/hr commercial scale plants. Minor differences in the plants using Pittsburgh-Bruceton and Upper Freeport coal were observed. The differences result from the higher ash content of the Upper Freeport coal, which requires more feed coal, compared to Pittsburgh-Bruceton coal, to yield the same clean coal product. The higher feed requirement results in more water and liquid carbon dioxide for the same production rate. For the purposes of the Proof-of-Concept and plant economic studies, Upper Freeport coal was selected as the reference coal, since this coal resulted in the slightly higher flow requirements, and hence the more conservative design parameters.

\subsubsection{Separator/Mixer Studies}

The plant simulation code has been used to perform a parametric study of the radius of the Separator for the Proof-of-Concept Plant. Parameters which were investigated include slurry concentration, $\mathrm{CO}_{2}$-to-coalwater slurry ratio, and residence time. Figures 6.2-1 through Figure 6.2-3 show the correlation between Separator radius and residence time at three $\mathrm{CO}_{2}$-to-slurry flow ratios; each figure represents a coal concentration in the slurry of 10,20 , or 30 percent, respectively. Figure 6.2-4 shows the correlation between Separator radius and slurry concentration at a residence time of 500 seconds and at $\mathrm{CO}_{2}$-to-slurry flow ratios of $0.20,0.35$, and 0.50 . The aspect ratio for the separator and mixer was fixed at 20 in these studies; i.e., the length is 20 times the radius. 


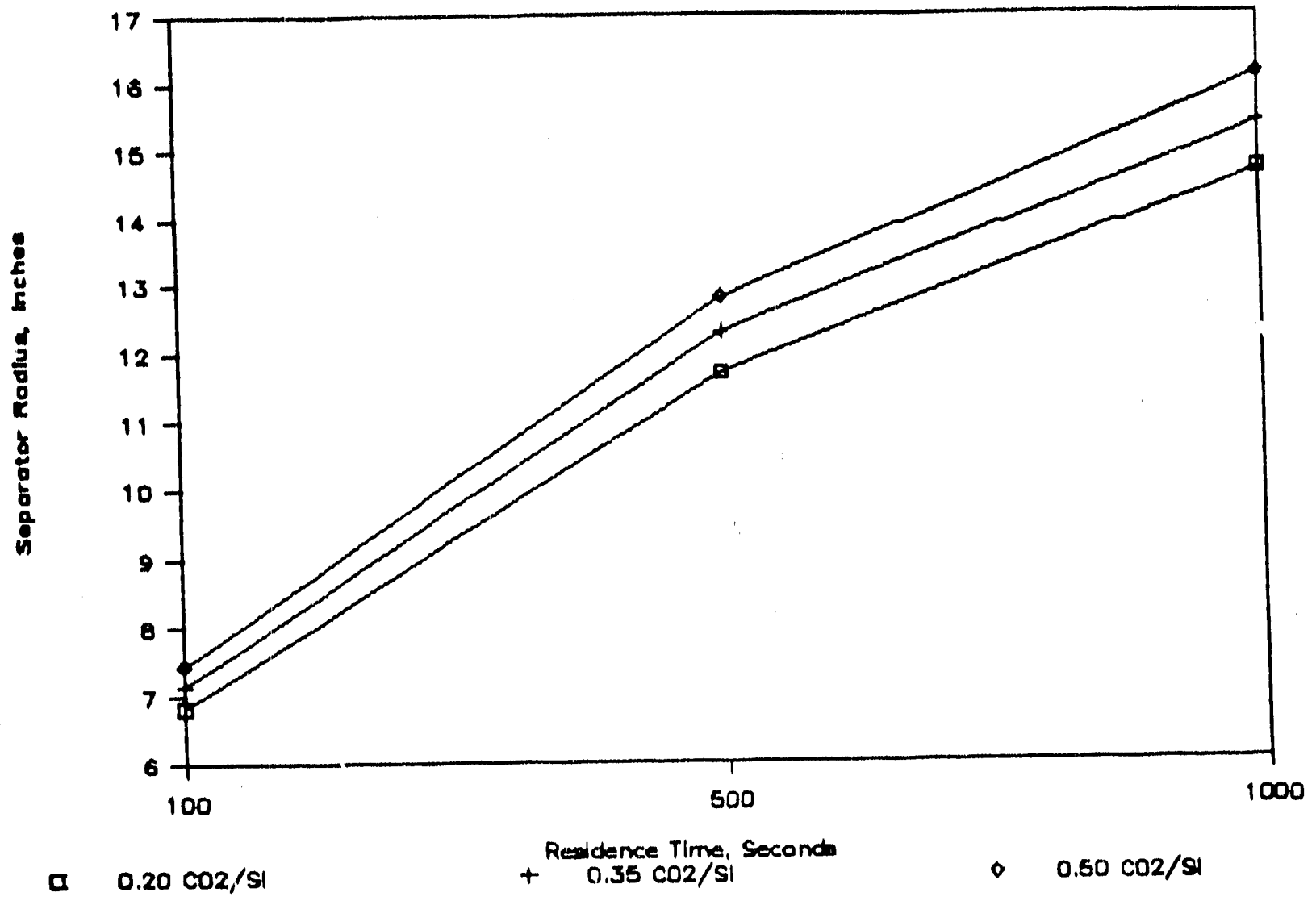

Figure 6.2-1. Separator Radit, 1 Ton/Hr Plant $10 \%$ Slurry Concentration 


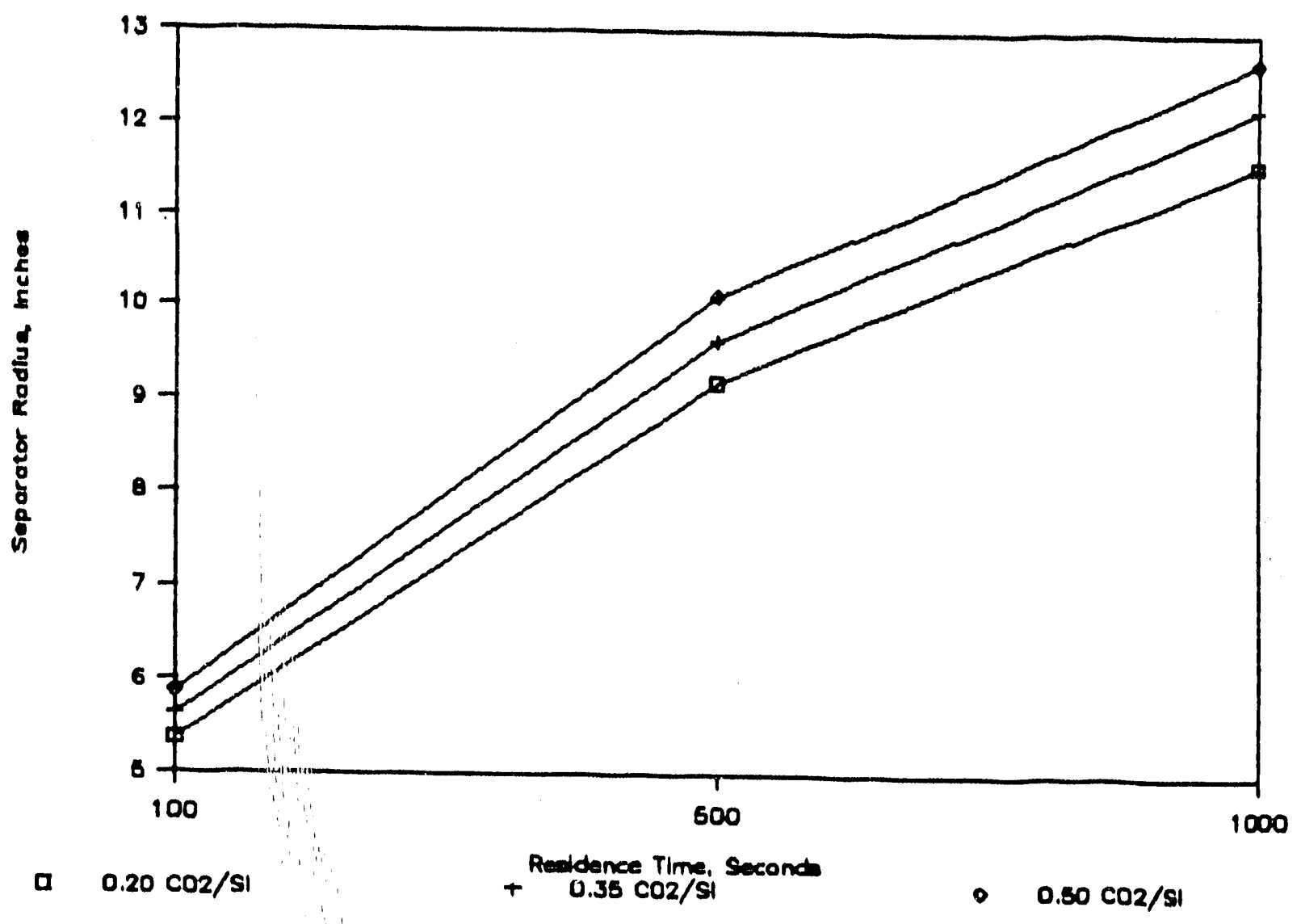

Figure 6.2-2. Separator Radii, 1 Ton/Hr Plant $20 \%$ Slurry Concentration

$6-8$ 


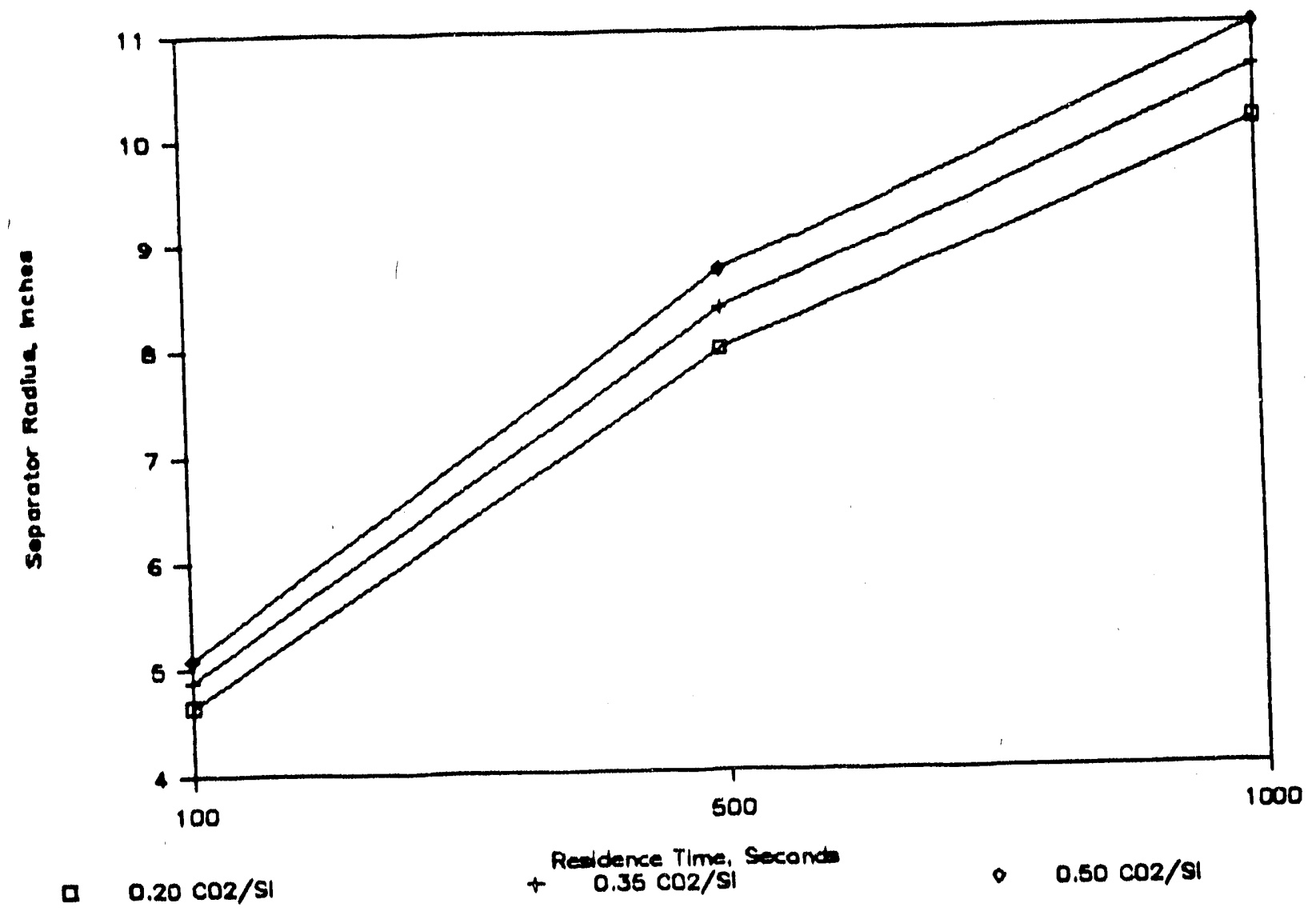

Figure 6.2-3. Separator Radii, I Ton/Hr Plant $30 \%$ Slurry Concentration 


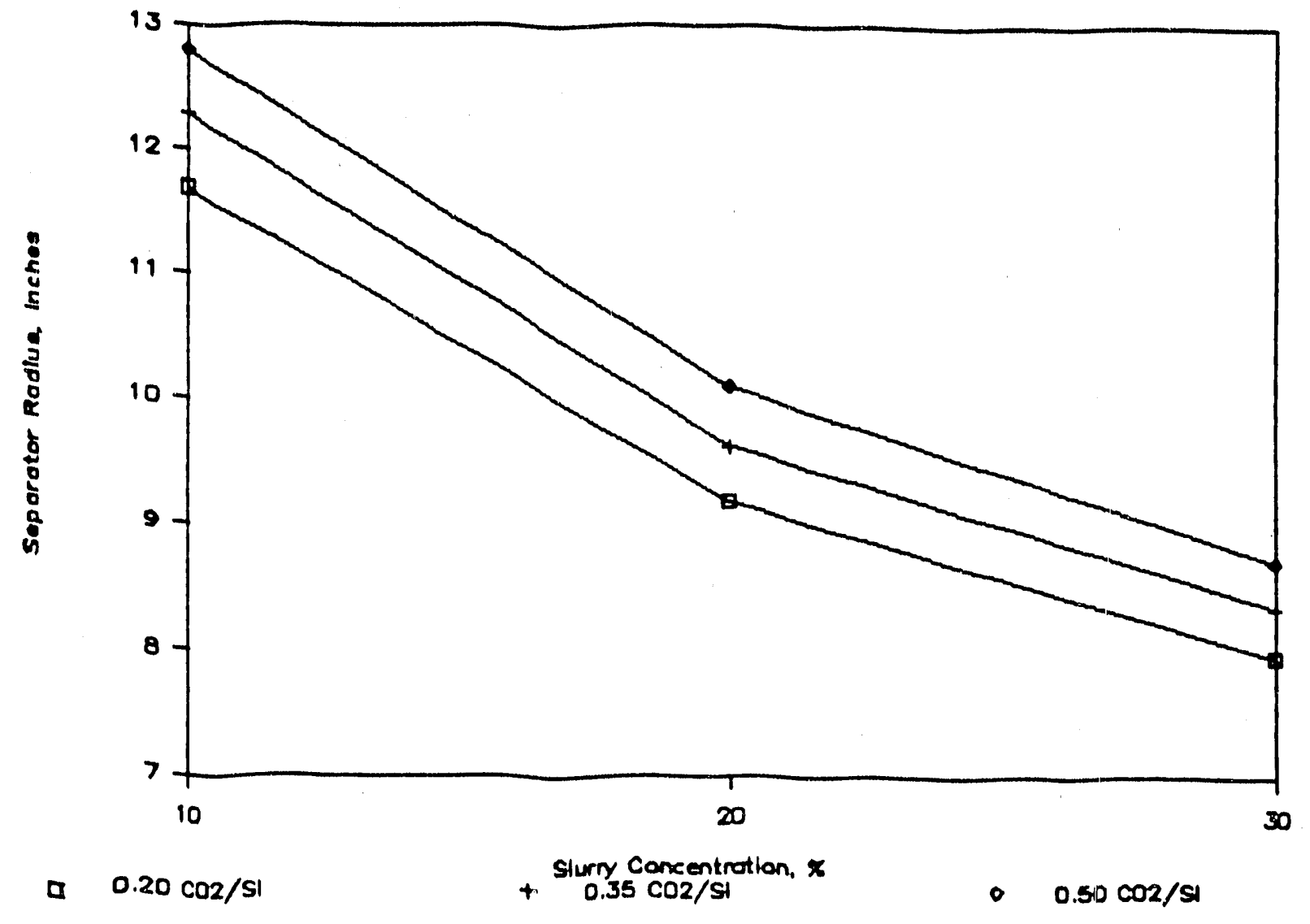

Figure 6.2-4. Separator Radii, 1 Ton/Hr Plant 500 Seconds Residence Time 
As expected, the Separator radius is a strong function of residence time and slurry concentration, and is a weaker function of $\mathrm{CO}_{2}$ flow ratio. The parameters for the preliminary design for the Proof-of-Concept Plant Separator were selected based upon test data which had been obtained with the Continuous Research Unit (CRU) and the Research Development Unit (RDU) as follows:

$$
\begin{array}{ll}
\text { Coal concentration in slurry } & 10 \% \\
\mathrm{CO}_{2} \text { to slurry flow ratio } & 0.50
\end{array}
$$

Residence Time $\quad 300$ seconds

With these parameters, the radius of the Separator for the Proof-ofConcept Plant is $26.7 \mathrm{~cm}$ (10.5 inches).

\subsubsection{Continuous Research Unit Study}

The potential maximum capacity of the Continuous Research Unit (CRU) was investigated using LIPS. Since the Separator Column is the critical component determining the maximum system capacity, a parametric study of the relationships among the column diameter, residence time, $\mathrm{CO}_{2} /$ slurry ratio, and coal concentration in the feed slurry was performed.

Figure 6.2-5 shows the Separator Column radius as a function of residence time at $\mathrm{CO}_{2}$ to water/coal feed slurry, and a clean coal production rate (Pittsburgh-Bruceton coal) of $100-1 \mathrm{~b} / \mathrm{hr}$. Since the radius of the CRU Separator column is $5.1 \mathrm{~cm}$ (2-inches), residence times of 120 to 150 seconds can be achieved at a product rate of $45.4 \mathrm{~kg} / \mathrm{hr}(100-1 \mathrm{~b} / \mathrm{hr})$. The required Separator radius increases as the $\mathrm{CO}_{2}$-to-feed slurry ratio rises. However, the $\mathrm{CO}_{2}$-to-feed slurry ratio is not a strong factor in determining the Separator radius. For example, at 100 seconds residence time, the range of $\mathrm{CO}_{2}$-to-feed slurry ratio of $250 \%$ (i.e., from $20 \%$ to $50 \%$ ) only results in a difference of about $10 \%$ in the Separator Column radius. 


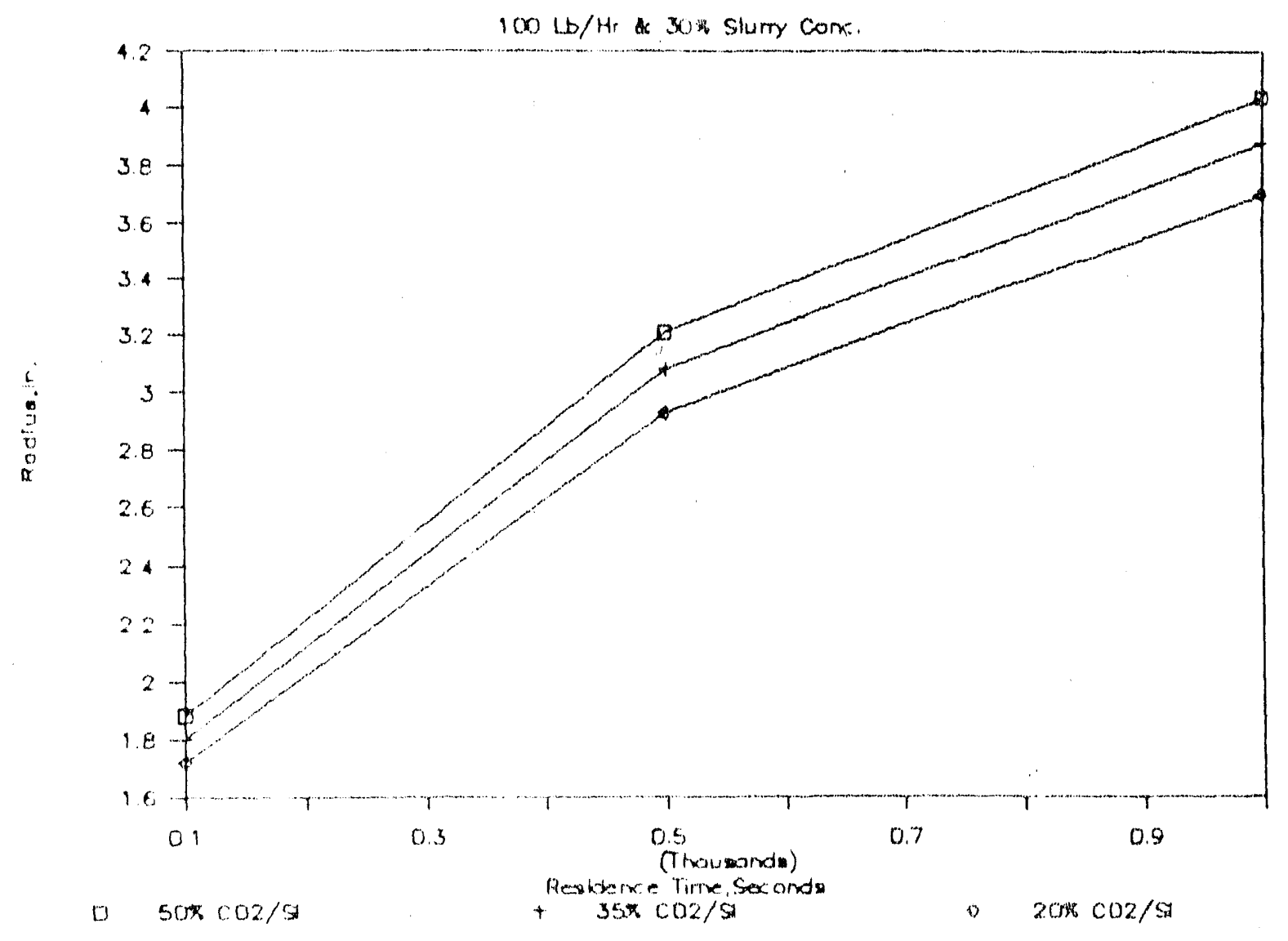

Figure 6.25. Separator Radi $V_{s}$. Residence Time 
The Separator radius is highly dependent upon the concentration of coal in the feed slurry. In Figure 6.2.6, the separator radius increases by about $50 \%$ as the coal concentration in the feed slurry decreases from $30 \%$ to $10 \%$.

The results of this study indicate that the CRU can be operated at a capacity of $45.4 \mathrm{~kg} / \mathrm{hr}(100-1 \mathrm{~b} / \mathrm{hr})$ and a Separator residence time of 100 seconds if the coal concentration in the feed slurry is $30 \%$. However, since the design objective of the continuous Unit is a clean coal capacity of $22.7 \mathrm{~kg} / \mathrm{hr}(50-1 \mathrm{~b} / \mathrm{hr})$, these results indicated that the Continuous Research Unit could be operated at this capacity without constructing a new system. Therefore, the proposed continuous system was not required. In order to provide the capacity for longer residence times and lower coal concentrations in the slurry, a $15.24 \mathrm{~cm}(6$-inch diameter) column was designed and constructed for the $22.7 \mathrm{~kg} / \mathrm{hr}(50.1 \mathrm{~b} / \mathrm{hr})$ capacity experi. ments. This column will provide an increase of more than a factor of two in residence time, compared to the $10.2 \mathrm{~cm}$ ( 4 -inch) diameter column in the Continuous Research unit. 


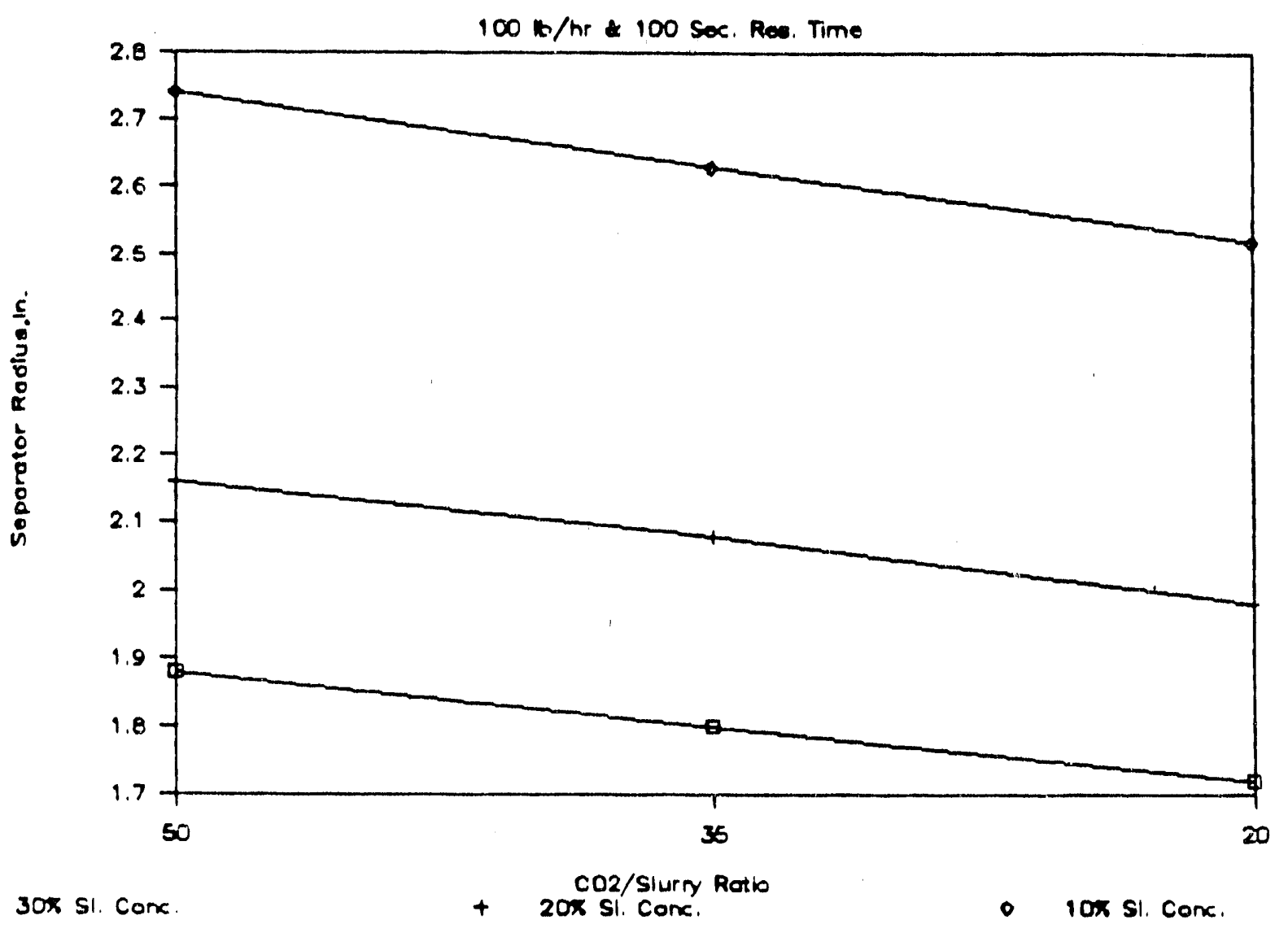

Figure 6.2-6. Separator Radii Vs. $\mathrm{CO}_{2} /$ Slurry Ratio

$$
6-14
$$




\subsection{CONCEPTUAL PLANT DESIGN}

Three coal beneficiation plants were conceptually designed. Two plants use the LICADO process to clean "Run of Mine" coal while the third plant processes the residual coal in the waste stream from a mine mouth coal washing plant or from a waste pond.

Most effort was applied to the LICADO Proof-of-Concept (POC) plant, operation of which will supply scaling factors, design, operating and maintenance information needed for extrapolation to a large plant. This plant was developed in the most detail, since its construction is planned for the next phase of the LICADO process development.

A commercial 181 metric ton/hr (200 tons/hr) LICADO plant was conceived, roughly sized, and used to establish a budgetary cost estimate for the economic evaluation. This site plant will supply fuel for a 500 MWe generating plant.

The third, waste stream recovery plant, processes 45 metric tons/hr (50 tons/hr) using $\mathrm{CO}_{\text {? }}$ to agglomerate coal fines in the waste of a washing plant stream or fines pumped from a waste pond. In this process, the agglomerated coal is recovered from the water phase by screening. A budgetary cost estimate of this plant was developed and used in the economic evaluations.

\subsection{Proof-of-Concept Plant}

Systems and components for a plant having the capacity to produce 0.91 metric ton (1 ton/hr) of clean coal provide a realistic first step scaleup from laboratory data and operation to the final commercial plant. Design and fabrication problems of components and systems are representa. tive of those which will be encountered in a larger plant. Design, construction, and operation of the POC plant will provide system data, component and equipment design information, component scaling criteria, and operating and mantenance experience required for a pilot plant of approximately 45 metric tons/hr ( 50 tons/hr). 
Experience will be obtained on the following plant operations and their subsystems:

- Coal Preparation: Preliminary cleaning to remove sand and other debris, grinding to a size of 200 mesh (85-90\%), adding water to form the optimum slurry concentration.

- Separation: High pressure slurry pumps, $\mathrm{CO}_{2}$ injection pumps, mixing and separation columns.

- Product Recovery: Clean coal product separation, $\mathrm{CO}_{2}$ recycle, recovery of desorbed gaseous $\mathrm{CO}_{2}$ from product, depressurization of product stream.

- Waste Treatment: Recovery of $\mathrm{CO}_{2}$ from waste stream, separation of water and recycle to slurry subsystem, dewatering of waste solids, disposal of waste solids.

- Product Handling: Sampling, weighing, and packaging of product coal in a safe manner.

\subsubsection{Requirements of the POC Plant}

The plant has been designed to meet the following overall requirements:

- Production rate will be 0.91 metric ton $/ \mathrm{hr}$ (1 ton $/ \mathrm{hr}$ ) of clean coal product.

- Feed material will be $5.1 \mathrm{~cm}$ (two-inch) top size bituminous coals, either Pittsburgh, Middle Kittanning, Upper Freeport, or 111 inois No. 6. 
- About $90 \%$ of the initial pyritic sulfur will be removed.

- The plant will operate using scaled versions of the same components, systems, and equipment to be installed in the commercial plant.

- Safe storage of the clean, powdered coal product will be provided using sealed, plastic lined drums with inert cover gas (argon).

- The waste produced by the process will be separated, the solids concentrated, and both liquids and solids will be disposed of in a lawful and safe manner.

- Sampling will be provided for the feed, product, and waste streams.

- A weighing and packaging station will be provided for shipment of clean coal. The components and system used in the POC plant will be different for this step in the process than that to be used in the commercial plant, which will pneumatically transport the product to storage silos. This operation will be performed in a $\mathrm{CO}_{2}$ atmosphere as a precaution against coal dust explosions.

Figure 7.1.1-1 presents the stream flows and material balance, which is the basis for the system design and component sizing. A system computer mode1, discussed in Section 6 , was developed to provide this information and to be used in scaling future larger plants. Input data used in the process flow sheet were based on the experimental data from the University 

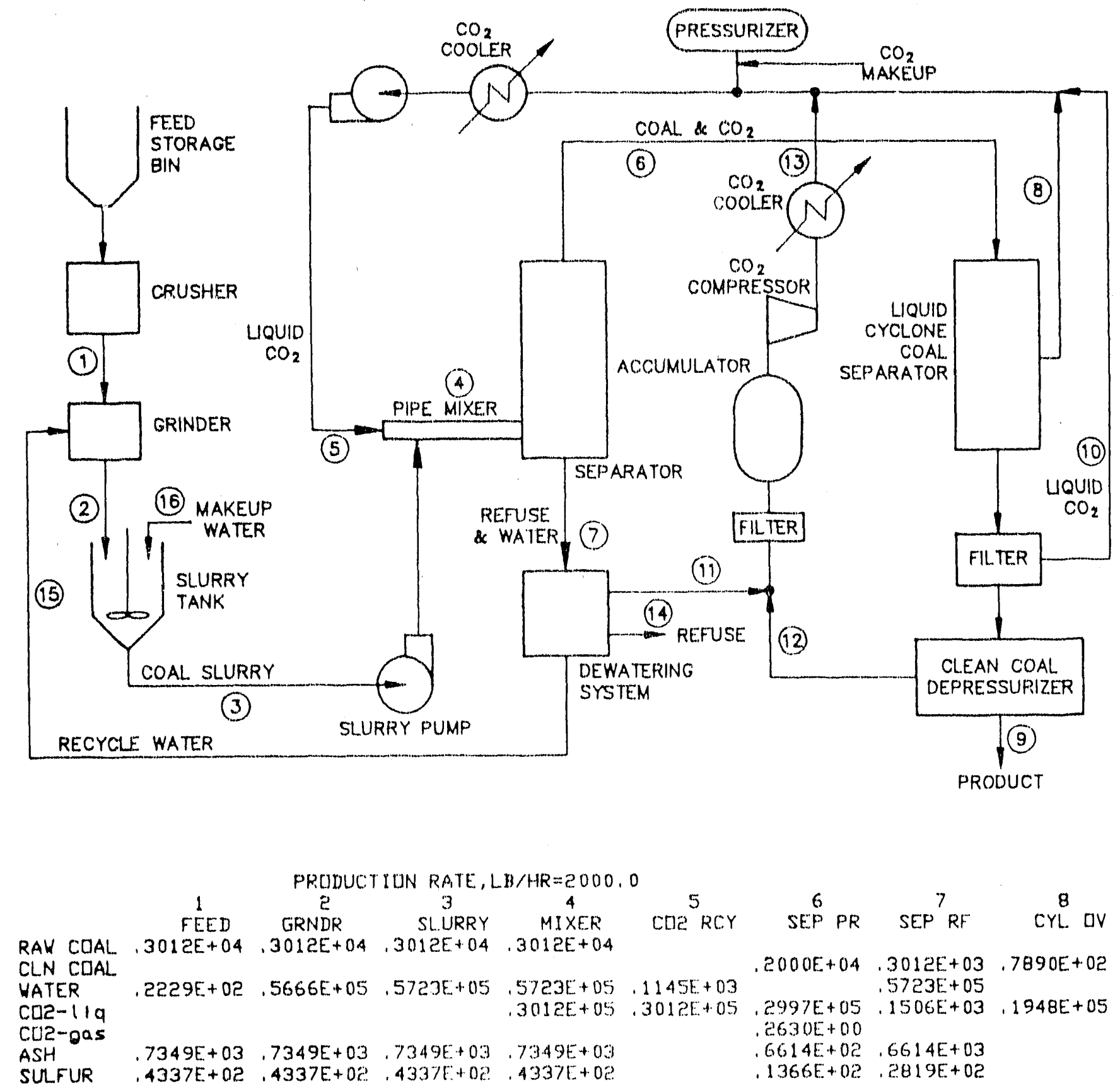

Figure 7.1.1.1. LICAOC Plant Simulation, Upper Ereoport Coal 
of Pittsburgh Variable Volume Batch Tests and Continuous Tests. These input data were:

Slurry Concentration, \% Solids. . . . . 10
Residence Time in Separator, minutes. . . 5
$\mathrm{CO}_{2}$ to slurry ratio (dimensionless. . . 0.5

Design Basis Coal. . . . . . . . Upper Freeport

Upper Freeport coal was selected as the design basis coal, since it has the largest ash content. Therefore, Upper Freeport coal requires the maximum feed rate which must be processed to yield the required product rate and results in the largest plant components.

\subsubsection{Process Consideration}

Investigation of methods, consultation services, and equipment supplier discussions were considered in selecting processes or components for the system. At the beginning it appeared that there were various ways to accomplish a desired condition. However, upon examination, the choices were reduced because of previously experienced operating problems, economics, or safety. The resulting design is considered to produce an economical product from a plant which is easily operated and safe to the environment, community, and plant personnel.

Decisions were made on 1) the coal feed preparation method, 2) product recovery $\left(\mathrm{coal} / \mathrm{CO}_{2}\right.$ separation), 3) maintaining the recycle water, pressurized or not.

\subsubsection{Coal Feed Preparation}

The coal preparation process has gone through three iterations. The first system used the standard atmospheric dry pulverizing which is generally 
used throughout the coal industry. The coal prep subsystem contatned a coal feed bin, crusher, conveyor, pulverizer, classifier, second conveyor, and fines storage hopper.

This system was chosen because it provides 200 mesh feed material with minimum capital expendilure, required $25 \%$ loss power per ton to operate than a wet process, and the dry product flows relatively eastly and could be transported and storod without much difficulty. However, after later data from the coal surface control project becance avallable, it was decided to wet grind the coal feed to reduce surface oxidation and enhance $\mathrm{CO}_{i}$ surface absorption during the contact process. From the safety aspect, wet grinding also reduces the potential for uncontrolled rapid fines oxidation which enhances the overall plant safety.

Flowability of wet coal fines are very poor; therefore, they are hydraulically transported at a solids concentration of $35 \mathrm{wt}$. \% or 1 ess. The coal preparation system operates at about atmospheric pressure; and the transport water must be replaced by pressurized recycie process water which contains approximately $5 \%$ dissolved $c_{0,}$. Thus, the majority of the transport water must be removed from the coal fines before they are charged to the process subsystem lock hopper.

During the conceptual plant design review, il was suggested that the best system for the foed size reduction would be to use a dry grinding system employing a $c\left(0\right.$, or $N_{i}$ demosphere in the ball mill and main.. latoing that atmosphere io the lock hopper. In this way the fines would be dry, onoxidied, flow freely, tramsport adsily, lhe correct slurry concentration could be simply ohtaimed, the captial cost and reduced power comsumption advantage would be revalued, and plant safoty would not be

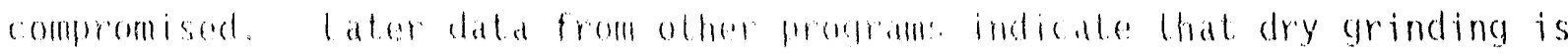
detrimental to ash rejection, and limentore lis option will not be

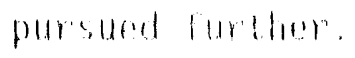




\subsubsection{Product Recovery (Coal/co, Separation)}

Cleaned coal is carried from the separator in the ligutd co, phase at approximately $5.86 \times 10^{\circ}$ rascals $(850)$ pstg and $21.1^{\circ} \mathrm{C}$ $\left(70^{\circ} \mathrm{F}\right)$. The next step must recover the coal from the liquid co, while maintaining the $c o$, in the liquid state for recycing. To reduce system pressure and vaporizing the co, would provide dry coal at atmospheric pressure; however, the $c^{\circ}$, vented to the atmosphere would not be beneficial to the enviroment and would be prohibitively costly. To recompress the $c_{2}$ for recycing would cost approxi. mately one-third of the original cost; but because of the large volume, this process would still be too expensive. Therefore, $\mathrm{CO}_{2} / \mathrm{Coal}^{2}$ separation must be accomplished at $\mathrm{CO}_{\text {? }}$ saturation pressure or greater.

Filter manufacturers were contacted to obtain performance and pricing information. of those contacted, only two could supply a high pressure filter with the required capacity: Industrial Filter and Pump Mfg. Company and MEMTEC America Corporation. Both suppliers suggest the same type of filter, generally called a candle filter, in which tubular filtering elements are suspended within a pressure shell. The coal solids are deposited on the outside of the filtering tubes while the riquid flows through to the inside of the lube. All of the filter tubes are connected to a common header before the clean liguid exits the pressure vessel. The manufacturers use two dillesent ways to recover the rilter cake. One bow: back from the filtrate side which dislodges the coal to the bottom of the veses. The second manufacturer vibrales the coal cake from the filter lutes, did the coal arops to the vessel bottom. In both cases, the coal must be receverod from the vessel bottom.

The manufacturer of the least expensive filter, who also provided the dryer and more adaptable system, quoted 40 filter units at an uninstalled cost of approximately $\$ 30$ million to provide 200 ton/hr of coal product. 
A system of pressurized settling tanks for concentrattrig the coal product, instead of filters, was considered. Plant capacity of 181 metric tons/hr (200 ton $/ \mathrm{hr}$ ) required a farm of $30,2.14 \mathrm{~m}(7 \mathrm{ft}$.) dianneter tanks. The ftlter cost was cut by approximately $1 / 3$; however, the $\mathrm{CO}_{2}$ recompression cost approached $\$ 30 /$ ton of product, which is too much.

Therefore, it appears that $d$ velopment of an efficient, high capacity, continuous filter system is required for a commercial plant. The continuous auger filter butlt by the University of Pittsburgh (Pitt) could be developed to fulfill the LICADO large plant requirement. However, during operation, the filter unit should be preceded by a cyclone to deslime the feed to the filter in order to reduce filter medium plugging.

For the POC plant, we have assumed that the auger type filter described in Section 7.1.5 will be developed for use at the commercial plant capacity.

\subsubsection{Pressurized Recycle Water}

A large volume of water is used to prepare the feed slurry in the LICADO process, therefore, requiring the water to be recycled both from an ecological and cost standpoint. During the reaction process, the water is intimately mixed with $\mathrm{CO}_{2}$ at approximately $6.20 \times 10^{6}(900$ psia $)$ and $21.1{ }^{\circ} \mathrm{C}\left(70^{\circ} \mathrm{F}\right)$ and becomes saturated at these conditions.

The solubilities of $\mathrm{CO}_{2}$ in water are:

$$
\begin{aligned}
& 0.17 \% \text { wt. at } 1.01 \times 10^{5}(14.7 \mathrm{psia}) \text { and } 21.1^{\circ} \mathrm{C}\left(70^{\circ} \mathrm{F}\right) \\
& 6.2 \% \text { wt. at } 6.21 \times 10^{6} \text { Pascals }(900 \mathrm{psia}) \text { and } 21.1^{\circ} \mathrm{C}\left(70^{\circ} \mathrm{F}\right)
\end{aligned}
$$

Should this water be allowed to return to an atmospheric holding pond from a pressurized refuse letdown tank, the lost $\mathrm{CO}_{2}$ would amount to about $\$ 96 /$ ton of product. If the water were depressurized and the escaping $\mathrm{CO}_{2}$ recompressed for recycling, the cost would be approximately $\$ 32 /$ ton of product. However, if the recycle water is maintained at 850 to 860 psta, the $\mathrm{CO}_{2}$ cost is between 5 to 10 cents/ton of product; and 
this is due to the $\mathrm{CO}_{2}$ absorbed on the product and refuse and $\mathrm{w}+11$ always be lost no matter what method is used. Therefore, the LICADO plant is designed to operate with a pressurized recycle water system.

\subsubsection{Plant Subsystems}

The LICADO system is basically five subsystems integrated into a continuous operating plant which supplies cleaned fine coal for combustion, Figure 7.1.3-1. The plant is fully automated and is computer controlled. Subsystems are:

- Feed Coal Preparation

- Liquid $\mathrm{CO}_{2}$ Processing

- Cleaned Coal Recovery

- Refuse Disposal

- Gaseous $\mathrm{CO}_{2}$, Recycle

- Product Handling

The POC coal preparation subsystem reduces $5.1 \mathrm{~cm}$ (2 inch) top-size coal to $90 \% \leq 200$ mesh fines, which are used as feed stock to the LICADO plant. The subsystem can measure and control one ton per hour of coal as it is crushed to approximately $0.64 \mathrm{~cm}$ (1/4 inch) material, then wet ground to 200 mesh as feed to the slurry tanks. In the slurry tanks, pressurized water is added to the fines to obtain the correct slurry concentration. The slurry is continuously mixed to maintain a homogeneous feed. Slurry pumps take suction from the tanks and deliver a controlled slurry rate at an increased pressure of approximately $4.14 \times 10^{5}(60$ psi) to the hydraulic mixer.

In the hydraulic mixer, liquid $\mathrm{CO}_{2}$ is thoroughly mixed with the coal

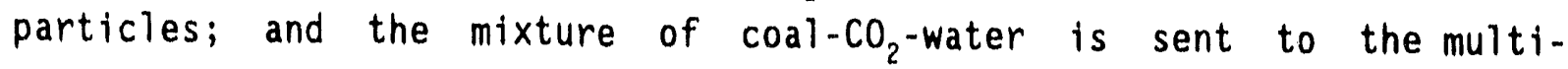
stage separator to facilitate additional $\mathrm{CO}_{2}$ contact and liquid phase separation. Here, the lighter $\mathrm{CO}_{2}$ phase containing the clean coal particles rises to the top of the separator, while the heavier water phase with refuse sinks to the separator bottom. 
UCADO, 1 TON/HOUR PROOF OF CONCEPT

PIPING \& INSTRUMENTATION DIAGRAM

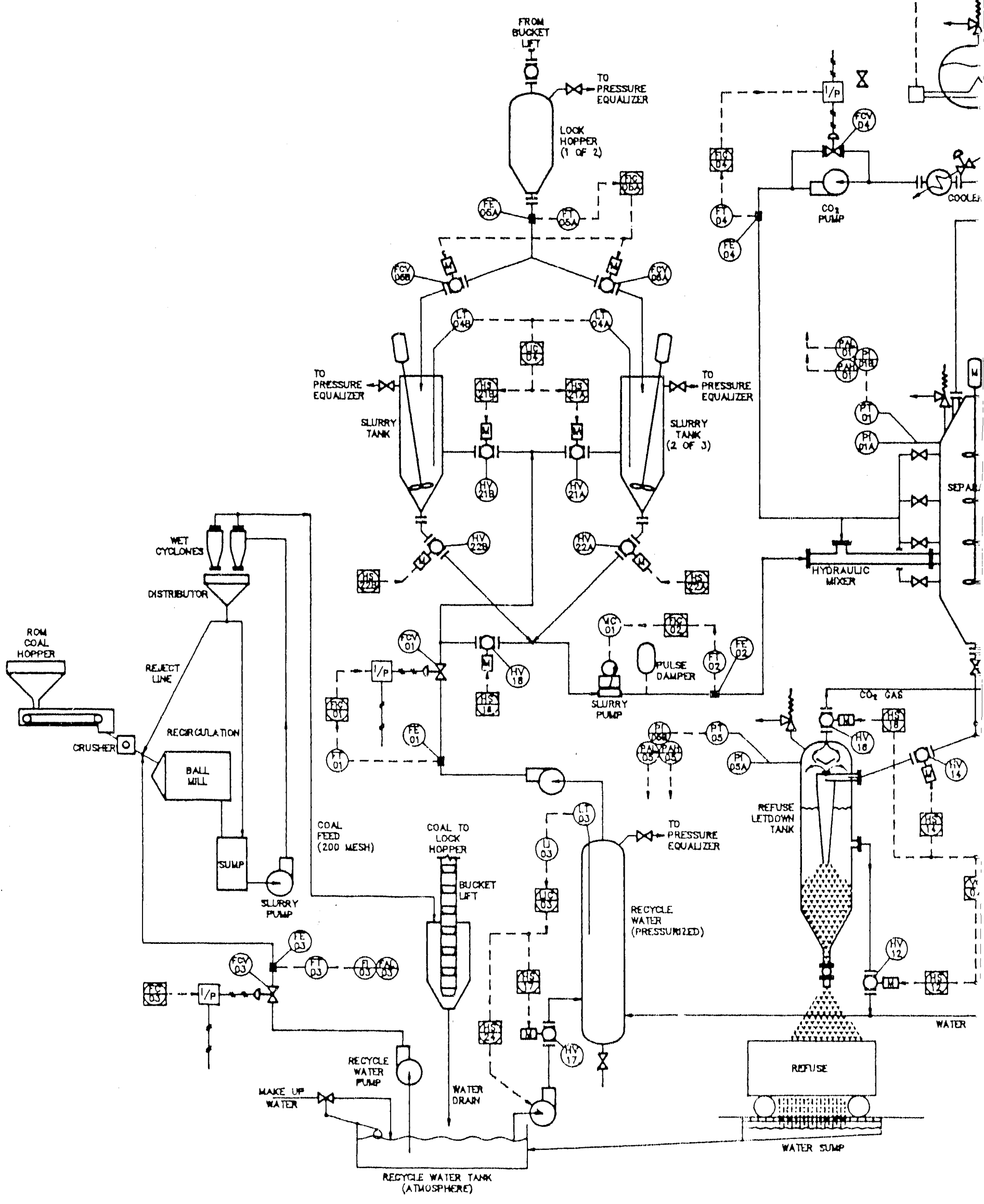




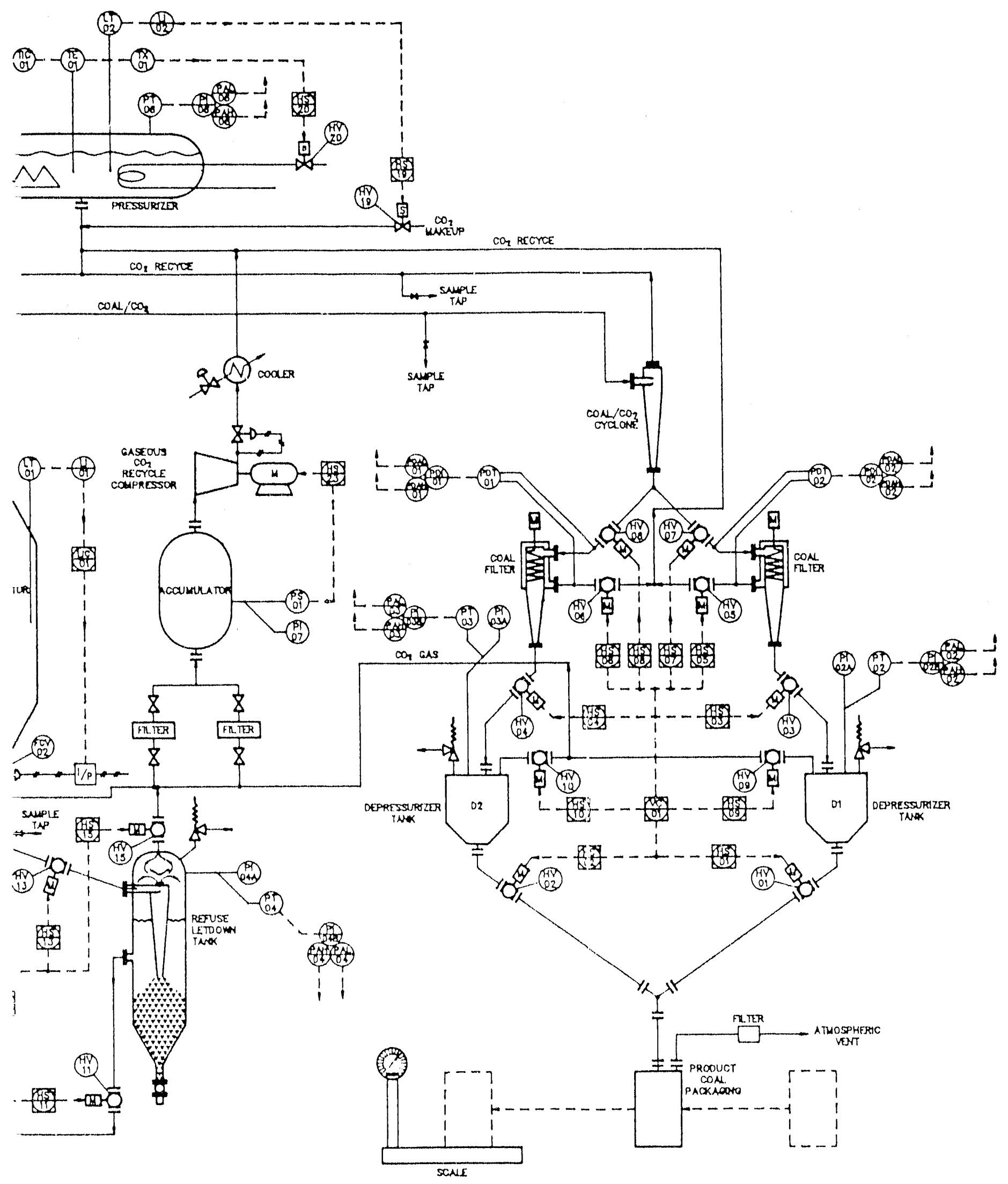

coneasom 10

Figure 7.1.3-1 
In the next two operations, the coal product is recovered and packaged while the refuse is reduced to atmospheric conditions and prepared for waste disposal.

The coal in the liquid $\mathrm{CO}_{2}$ phase is concentrated in a cyclone from around $6-1 / 2 \%$ solids to $16-1 / 2 \%$ solids before the coal product is stripped from the remaining $\mathrm{CO}_{2}$ using a high pressure filter. The filter cake is reduced to atmospheric conditions, then is drummed for shipment. The drums will be provided with a plastic liner, and the drums will be filled with argon gas prior to sealing. The liquid $\mathrm{CO}_{2}$ overflow from the cyclone and the filtrate from the filters is returned to the system pressurizer, from which it is recycled to the separator.

The refuse material (ash and pyritic sulfur) is concentrated through a cyclone from around $3-1 / 2 \%$ solids to an underflow of about 30 to $35 \%$ solids, and then allowed to settle from the water phase in a refuse letdown tank. The high pressure water from both the cyclone and the settled solids is sent to pressurized recycle water storage. The settled solids are extruded from the tank bottom into drums for refuse disposal.

Gaseous $\mathrm{CO}_{2}$ from the product and refuse depressurization is accumulated, recompressed, cooled to liquid, and returned to the system for recycling.

The process operates at saturated $\mathrm{CO}_{2}$ conditions of $21.1^{\circ} \mathrm{C}$ $\left(70^{\circ} \mathrm{F}\right)$ and $5.88 \times 10^{6}$ Pascals $(853 \mathrm{psia})$. Insulation and a $\mathrm{CO}_{2}$ loop cooler maintain the system temperature at $21.1^{\circ} \mathrm{C}$ $\left(70^{\circ} \mathrm{F}\right)$. A loop pressurizer through heating and cooling capability automatically maintains the required system pressure.

The $\mathrm{CO}_{2}$ /water liquid interface level in the separator is controlled through setting the flow rates of the inlet $\mathrm{CO}_{2}$ and slurry to the mixer and controlling the outflow of the water/refuse from the separator 
using the level signal. This also automatically establishes $\mathrm{CO}_{2} /$ coal flow from the separator. This control scheme is routinely used to control the interface in the Continuous Research Unit.

\subsubsection{Instrumentation and Control System}

The POC plant will be computer-controlled with operator attention in the control room and two operators in the plant to supply raw coal to the feed hopper, handle product and refuse drums, and survey equipment operations.

The control system computer will consist of an IBM PC/AT operating a multitasking version of DOS. The computer will be dedicated to the process control tasks necessary for the plant, with these functions taking precedence over the logging capabilities of the computer. Specifically, the system will have 640K memory with a floppy drive and a $20 \mathrm{M}$ hard drive. The hard drive will be used mainly to store data collected during plant runs. The computer will consist of plug-in boards in a standard PC/AT backplane encased in a rugged housing. The boards are identified below:

1) PC/AT Processor Card

2) 640K Memory Card

3) Disk Drive Controller Card

4) Graphics Controller Board

5) Digital 1/0 Board (24 Inputs)

6) Digital 1/0 Board (24 Outputs)

7) Analog $1 / 0$ Board (16 Inputs)

8) Analog $1 / 0$ Board ( 6 Inputs)

Several expansion slots will be left open for future requirements. The numerous different suppliers of these boards and the rapid growth of the market make the specific selection of the manufacturer unnecessary at this time. The final computer layout will not take place until the final design phase of the plant. In addition, the selection of a specific computer language ( $C$, Basic, Fortran, etc.) to program functions will be delayed until a later date. 
To properly isolate control system signals from the field devices, industry, standard I/0 modules will be used. Signals to/from the computer $1 / 0$ boards will be run through the modules for two purposes. First, to ensure optical isolation from the sensitive computer boards so that a failure or overvoltage does not do serious damage to the control system. Second, to provide a means to condition the computer board signals to the levels necessary for field activation of valves/motors.

Although a layout sketch of the control system was not undertaken at this time, a process I/0 list for the control system was prepared and is shown in Table 7.1.4-1. This listing describes the process control inputs and outputs of the computer and does not cover the operator inputs (emergency stop, start, stop, continue buttons, etc.) and outputs (annunciators, control panel lights, etc.), which will be configured during the final design stage.

The Piping and Instrumentation Diagram (P\&ID) is shown as Figure 7.1.3-1. The circle and bar symbol is used for functions included in the control room. The plain circle symbol for field mounted devices. The dashed line with an arrow symbol is used to indicate that the measurement/function is either input to or generated from the control system. The circle in a box symbol indicates a signal generated by the control system computer for the purpose of process control. No other attempt will be made, on the P\&ID, to show the interaction between plant systems that take place in the control system computer. These interactions will be developed and documented later in the form of microprocessor software.

A Measurement Requirements List (MRL), shown in Table 7.1.4-2, was generated based on the preliminary P\&ID. This listing defines the function or purpose for which each of the measurements shown on the P\&ID is to be used. Each process measurement point shown on the P\&ID is listed with a short word description of the parameter and the number of any valve or 
DIGITAL INPUTS

Description

1) Lo Seperator Press. 115 VAC

2) Hi Seperator Press. 115 VAC

3) Lo Depressurizer Tank \#1 Pressure

4) Hi Depressurizer Tank \#1 Pressure

5) Lo Depressurizer Tank \#2 Pressure

6) Hi Depressurizer Tank \#2 Pressure

7) Lo Refuse Letdown Tank \# I Pressure

8) Hi Refuse Letdown 115 VAC Tank \#1 Pressure

9) Lo Refuse Letdown 115 VAC Tank \#2 Pressure

10) Hi Refuse Letdown 115 VAC Tank \#2 Pressure

11) Lo $\mathrm{CO}_{2}$ Tank Press $115 \mathrm{VAC}$

12) $\mathrm{Hi} \mathrm{CO} 2$ Tank Press $115 \mathrm{VAC}$

13) Lo Filter \#2 Dif. 115 VAC Pressure

14) $\mathrm{Hi} \mathrm{CO} 2$ Tank Press $115 \mathrm{VAC}$ Pressure

15) Lo Filter \#2 Dif. 115 VAC Pressure

16) Hi Filter \#2 Dif. 115 VAC Pressure

17) $\mathrm{CO}_{2}$ Accumulator $115 \mathrm{VAC}$ Pressure Switch (LO)

18) $\mathrm{CO}_{2}$ Accumulator $115 \mathrm{VAC}$ Pressyre Switch ( $\mathrm{Hi})$

ANALOG INPUTS

Description

1) Level Xmitter for Seperator

2) Level Xmitter for $\mathrm{CO}_{2}$ Pressure Tank

3) Temp. for $\mathrm{CO}_{2}$ Pressure Tank

4) Water to Slurry Tank Flow Rate

5) Slurry to Mixer Flow Rate

6) Liquid $\mathrm{CO}_{2}$ to Mixer Flow Rate

7) Coal to Slurry Tank 4-20 mA Flow Rate

8) Water to Coal Crusher Flow Rate

9) Level Xmitter for Recycle Water Tank

10) Level Xmiter for Slurry Tank

ANALOG OUTPUTS

Description

1) Temp. Control for 0-5 V $\mathrm{CO}_{2}$ Pressure Tank

2) Seperator Interface 4-20 mA Level Control Valve

3) Water to Slurry Tank 4-20 mA Flow Control Valve

4) Slurry Pump Motor 0-5 V Speed Control

5) Liquid $\mathrm{CO}_{2}$ to Mixer 4-20 mA Flow Control Valve

6) Coal to Slurry Tank 4-20 mA 6 Flow Control Valve

7) Water to Coal Crusher 4-20mA

Qty

4-20 mA

4-20 mA

4-20mA

4-20 mA

4-20mA

4-20mA

4-20mA 3

Leve1 2 
TABLE 7.1.4-1

CONTROL SYSTEM

DIGITAL OUTPUTS

\section{Description}

1) Depressurizer to Coal Bin Valve

2) Depressurizer to Coal Bin Valve

3) Filter \#1 to Depressurizer Valve

4) Filter \#2 to Depressurizer Vaive

5) Filter $\# 1 \mathrm{CO}_{2}$ Recycle Line Valve

6) Filter \#2 $\mathrm{CO}_{2}$ Recycle Line Valve

7) Cyclone to Filter \#1 Valve

8) Cyclone to Filter \#2 Valve

9) Depressurizer $\mathrm{CO}_{2}$ Recycle Valve

10) Depressurizer $\mathrm{CO}_{2}$ Recycle Valve

11) Refuse Tank \#1 Water Drain Valve

12) Refuse Tank \#2 Water Drain Valve

13) Seperator to Refuse Tank \#1 Valve

14) Seperator to Refuse Tank \#2 Valve

15) Refuse Tank \#1 $\mathrm{CO}_{2}$ Recycle Valve

16) Refuse Tank \#2 $\mathrm{CO}_{2}$ Recycle Valve

17) Water Make Up Valve

18) Water Tank to Slurry Pump Valve

19) $\mathrm{CO}_{2}$ Makeup Line Solenoid Valve

20) $\mathrm{CO}_{2}$ Tank Cooling Solenoid Valve

21) Water to Slurry Tank

22) Slurry Tank to Slurry Pump Valve

23) $\mathrm{CO}_{2}$ Compressor Motor Starter
Level

$\underline{Q t y}$

( HS-01) 115 VAC

( HS-02) 115 VAC

( HS-03) 115 VAC

( HS-04) 115 VAC

( HS-05) 115 VAC

( HS-06) 115 VAC

( HS-07) 115 VAC

( HS-08) 115 VAC

( HS-09) 115 VAC

(HS-10) 115 VAC

( HS-11) 115 VAC

( HS-12) 115 VAC

( HS-13) 115 VAC

(HS-14) 115 VAC

(HS-15) 115 VAC

(HS-16) 115 VAC

( HS-17) 115 VAC

( HS-18) 115 VAC

( HS-19) 115 VAC

( HS-20) 115 VAC

( HS.21) 115 VAC 3

(HS-22) 115 VAC 3

( HS-23) 115 VAC 
TABLE 7.1.4-2

MEASUREMENTS REQUIREMENTS LIST

\begin{tabular}{|c|c|c|c|c|c|c|c|c|c|}
\hline & & CONTROL & & & TYPE & & & & \\
\hline & & & & & & & & & \\
\hline \multirow[t]{2}{*}{ PTO1 } & SEPERATOR TANK & INTERLOOCK/ & LOCAL & & DIAPHRAGM/ & & $0-1000$ & & \\
\hline & PRESSURE & ALARM & REMOTE & & CAPACITIVE & $4-20 \mathrm{~mA}$ & PSIG & & \\
\hline \multirow[t]{2}{*}{ PT02 } & DEPRESSURIZING TANK & INTERLOCK/ & LOCAL & & DIAPHRAGM/ & & $0-8501$ & & \\
\hline & PRESSURE & ALARM : & REMOTE & & CAPACITIVE & $4-20 m A$ & PSIG & & \\
\hline \multirow[t]{2}{*}{ PTO3 } & DEPRESSURIZING TANK $\# 2$ & INTERLOCK/ & LOCAL & & DIAPHRAGM/ & & $0-850$ & & \\
\hline & PRESSURE & ALARM & REMOTE & & CAPACITIVE & $4-20 \pi A$ & PSIG & & \\
\hline \multirow[t]{2}{*}{ PT04 } & REFUSE LETDOWN TANK 1 & INTERLOCK/ & LOCAL & & DIAPHRAGM/ & & $0-2001$ & & \\
\hline & PRESSURE & ALARM & REMOTE & & CAPACITIVE & 4-20mA & PSIG & & \\
\hline \multirow[t]{2}{*}{ PT05 } & REFUSE LETDOWN TANK 2 & INTERLOCK/ & LOCAL & & DIAP,HRAGM/ & & $0-200$ & & \\
\hline & PRESSURE & ALARM & REMOTE & & CAPACITIVE & 4-20mA & PSIG & & \\
\hline \multirow[t]{2}{*}{ PT06 } & $\mathrm{CO}_{2}$ PRESSURE TANK & | INTERLOCK/ & | & & DIAPHRAGM/ & & $0-1000 \mid$ & & \\
\hline & PRESSURE & $\perp$ ALARM & REMOTE & & CAPACITIVE & $4-20 m A$ & PSIG & & \\
\hline \multirow[t]{2}{*}{ PDTO1 } & I FILTER I DIFFERENTIAL & / INTERL.OCK/ & & & DIAPHRAGM/ & & $0-25 \mid$ & & \\
\hline & $\perp$ PRESSURE & $\perp$ ALARM & REMOTE & & CAPACITIVE & $4-20 \mathrm{~mA}$ & PSIO & & \\
\hline \multirow[t]{2}{*}{ PDTO2 } & | FILTER 2 DIFFERENTIAL & I INTERLOCK/ & & & DIAPHRAGM/ & & $0-251$ & & \\
\hline & $\perp$ PRESSURE & $\perp \quad$ ALARM & REMOTE & & CAPACITIVE & L-20mA & PS10 & & \\
\hline \multirow[t]{2}{*}{ LTO2 } & $\mathrm{I}_{\mathrm{CO}}$ PRESSURE TANK & | & | & & CAPACITIVE & & & & \\
\hline & L LEVEL (HV19) & REMOTE & REMOTE & & INTERFACE & $4-20 \mathrm{~mA}$ & & & \\
\hline \multirow[t]{2}{*}{ TE01 } & $\mathrm{I}_{2}$ PRESSURE TANK & & & & & | & & & \\
\hline & L TEMP $\quad($ HV2O,TICO1) & REMOTE & $N / A$ & & & & & & \\
\hline \multirow[t]{2}{*}{ PSO1 } & | HI/LO PRESSURE SWITCH & & & & DIAPHRAGM & & & & \\
\hline & $\perp C O$, ACCUMULATOR (HS2L) & REMOTE & LOCAL & & & $\perp$ DIGITAL & & & \\
\hline \multirow[t]{2}{*}{ LTO1 } & I SEFERATOR TANK INTERFACE & & & & CAPACITIVE & & & & \\
\hline & $\perp$ LEVEL $\quad(F C V-02)$ & REMOTE & REMOTE & & INTERFACE & $4-20 \pi A$ & & & \\
\hline \multirow[t]{2}{*}{ FE01 } & I WATER TO SLURRY TANK & & | & & TURBINE & & $0-100$ & & \\
\hline & L FLOW $\quad(\mathrm{FCV}-01)$ & REMOTE & REMOTE & & FLOW METER & $4-20 \pi A$ & GPM & & \\
\hline \multirow[t]{2}{*}{ FEO2 } & | SLURRY TO SEPERATOR & & & & FULL PORT MASS & & $0-100$ & & \\
\hline & $\perp$ TANK FLOW $(M C-01)$ & REMOTE & REMOTE & & FLOW METER & $4-20 m A$ & GPM & & \\
\hline \multirow[t]{2}{*}{ FEO3 } & I WATER TO COAL CRUSHER & & & & TURBINE & & & & \\
\hline & LFLOW $\quad(\mathrm{FCV}-03)$ & & REMOTE & & FLOW METER & & & & \\
\hline \multirow[t]{2}{*}{ FEO4 } & I LIQUID $\mathrm{CO}_{2}$ TO MIXER & & & & TURBINE & & $0-100$ & & \\
\hline & LFLOW $[\mathrm{FCV}-04)$ & REMOTE & REMOTE & & FLOW METER & $\mid 4-20 \mathrm{~mA}$ & $\perp G P M$ & & \\
\hline \multirow[t]{2}{*}{ LTO3 } & I RECYCLE WATER TANK & | & | & & FLOAT/OTHER & & & & \\
\hline & $\perp$ LEVEL (HS24) & REMOTE & REMOTE & & & $\perp 4-20 m A$ & & & \\
\hline \multirow[t]{2}{*}{ LTO4 } & I SLURRY TANK LEVEL & | & | & & & | & & & \\
\hline & I (HV L & & & & & & & & \\
\hline \multirow[t]{6}{*}{ FE05 } & I COAL TO SLURRY TANK & | & | & & & | & | & & \\
\hline & 1 FLOW (FCF-05) & & REMOTE & & & & & & \\
\hline & 1 & | & 1 & & & | & 1 & & \\
\hline & & & & & & & & & \\
\hline & & & | & & & 1 & | & & \\
\hline & & & & & & & & & \\
\hline
\end{tabular}


motor controlled by the measurement shown in parentheses. The location and/or purpose of the control, indication, and alarm requitrements is shown. Local and remote entries refer to field mounted devices and control room functions, respectively. The type of process instruments to be used has been identified along with the output signal and range. When more information is avallable, the response time and accuracy requirement of the parameter measurement wil1 be added.

A Control Valve List (CVL), shown in Table 7.1.4-3, was generated based on the P\&ID. This listing defines the valve number, type, size, and control system requirements. Each control valve is identified with a valve number and a description. An attempt was made to standardize the valve types and sizes in order to simplify the purchasing and maintenance of the system. The pipe size and pressure requirements are shown. This list includes only valves controlled by signals generated in the control system computer. The control column shows the type of computer signal (digital or analog) the valve requires. As would be expected, a digital signal commands the valve either to open or close; while an analog signal is used to proportionally control the value stem position. At this time, the digitally-controlled valves use motor actuators (air actuators w/solenoid control is another option being considered); and the analog valves use airoperated diaphragm actuators.

\subsubsection{Description of POC P1ant}

For the purposes of this design study, the Proof-of-Concept Plant was located in the GPL-1 Building at the Westinghouse Waltz Mill site.

A preliminary concept of the plant was arranged within the GPL-1 building which will require an additional structure on its roof to acconmodate the height of the pressurized coal/water slurry feed system, separator column, and system pressurizer. Also, a new extension is required to cover the coal weight feeder, crusher, and part of the bal1 mill. 
TABLE $7.1 .4-3$

CONTROL VALVE LIST

| VALVE | DESCRIPTION

LPIPE SIZE $\perp$ CONTROL $\perp$ PRESSURE $\perp$ TYPE ACTUATOR

\begin{tabular}{|c|c|c|c|c|c|c|c|}
\hline$H S-01$ & Depressurizer to Coal Bin Valve & 2 & Inch & Dlg|tal & $850 \mathrm{PSIG}$ & $\begin{array}{l}\text { Full Port Ball } \\
\text { Tef Ion Seals }\end{array}$ & $\begin{array}{l}\text { Electric } \\
\text { Motor }\end{array}$ \\
\hline HS- 02 & Depressurizer to Coal Bin Valve & 2 & inch & Digltal & 850 PSIG & $\begin{array}{l}\text { Full Port Ball } \\
\text { Teflon Seals }\end{array}$ & $\begin{array}{l}\text { Electric } \\
\text { Motor }\end{array}$ \\
\hline HS- 03 & Fllter 1 to Depressurizer Valve & 2 & Inch & Digital & 850 PSIG & $\begin{array}{l}\text { Full Port Ball } \\
\text { Teflon Seals }\end{array}$ & $\begin{array}{l}\text { Electric } \\
\text { Motor }\end{array}$ \\
\hline HS- 04 & Fllter 2 to Depressurizer Valve & 2 & inch & Digital & 850 PSIG & $\begin{array}{l}\text { Full Port Ball } \\
\perp \text { Teflon Seals } \\
\end{array}$ & $\begin{array}{l}\text { Electric } \\
\text { Motor }\end{array}$ \\
\hline HS-05 & Filter $1 \mathrm{CO}_{2}$ Recycle Line Valve & 2 & Inch & Digital & 850 PSIG & $\begin{array}{l}\text { Full Port Ball } \\
\text { Teflon Seals }\end{array}$ & $\begin{array}{l}\text { Electric } \\
\text { Motor }\end{array}$ \\
\hline HS- 06 & Filter $2 \mathrm{CO}_{2}$ Recycle Line Valve & 2 & inch & Digital & $850 \mathrm{PSIG}$ & $\begin{array}{l}\text { Full Port Ball } \\
\text { Ieflon Seals } \\
\end{array}$ & $\begin{array}{l}\text { E. lectric } \\
\text { Motor }\end{array}$ \\
\hline HS- 07 & Cyclone to Filter 1 Valve & 2 & Inch & Digital & 850 PSIG & \begin{tabular}{|l|} 
Ful1 Port Ball \\
Leflon Seals \\
\end{tabular} & $\begin{array}{l}\text { Electric } \\
\text { Motor }\end{array}$ \\
\hline HS- 08 & Cyclone to Filter 2 Valve & 2 & inch & Digltal & 850 PSIG & $\begin{array}{l}\text { Ful1 Port Ball } \\
\text { Leflon Seals }\end{array}$ & $\begin{array}{l}\text { ictric } \\
\text { or }\end{array}$ \\
\hline HS- 09 & Depressurizer $\mathrm{CO}_{2}$ Recyc le Valve & 1 & inch & Dig|tal & $850 \mathrm{PSIG}$ & $\begin{array}{l}\text { I Ful1 Port Ball } \\
\perp \text { Ieflon Seals }\end{array}$ & $\begin{array}{l}\text { ictric } \\
\text { or }\end{array}$ \\
\hline$H S-10$ & Depressurizer $\mathrm{CO}_{2}$ Recycle Valve & 1 & inch & Digital & 850 PSIG & $\begin{array}{l}\text { Full Port Ball } \\
\perp \text { Teflon Seals } \\
\end{array}$ & $\begin{array}{l}\text { Electric } \\
\text { Motor }\end{array}$ \\
\hline$H S-11$ & Refuse Tank 1 Water Drain Valve & 2.5 & inch & Digltal & 200 PSIG & $\begin{array}{l}\text { Full Port Ball } \\
\text { Standard Seals } \\
\end{array}$ & $\begin{array}{l}\text { Electric } \\
\text { Motor }\end{array}$ \\
\hline HS- 12 & Refuse Tank 2 Water Drain Valve & 2.5 & inch & Digital & 200 PSIG & $\begin{array}{l}\mid \begin{array}{l}\text { Full Port Ball| } \\
\text { Ltandard Seals }\end{array} \\
\end{array}$ & $\begin{array}{l}\text { Electric } \\
\text { Motor }\end{array}$ \\
\hline$H S-13$ & Seperator to Refuse Tank 1 Valve & 2.5 & inch & Digital & 850 PSIG & $\begin{array}{l}\text { Full Port Bal1 } \\
\text { Ief lon Seals } \\
\end{array}$ & $\begin{array}{l}\text { Electric } \\
\text { Motor }\end{array}$ \\
\hline$H S-14$ & Seperator to Refuse Tank 2 Valve & 2.5 & inch & Digital & $850 \mathrm{PS} 1 \mathrm{G}$ & $\begin{array}{l}\text { Ful1 Port 8al1 } \\
\perp \text { Teflon Seals } \\
\end{array}$ & $\begin{array}{l}\text { Electric } \\
\text { Motor }\end{array}$ \\
\hline$H S-15$ & Refuse Tank $1 \mathrm{CO}_{2}$ Recycle Valve & 1 & inch & Digltal & $850 \mathrm{PSIG}$ & $\begin{array}{l}\text { Full Port Ba!l } \\
\perp \text { Teflon Seals } \\
\end{array}$ & $\begin{array}{l}\text { Electric } \\
\text { Motor }\end{array}$ \\
\hline HIS- 16 & Refuse Tank $2 \mathrm{CO}_{2}$ Recycle Valve & 1 & inch & Digital & $850 \mathrm{PSIG}$ & $\begin{array}{l}\text { Full Port Ba } 11 \\
\text { Leflon Seals } \\
\end{array}$ & $\begin{array}{l}\text { Electric } \\
\text { Motor }\end{array}$ \\
\hline HS -17 & Water Make Up Valve & & & Digltal & 850 PSIG & & \\
\hline$H S-18$ & Water Tank to Slurry Pump Valve & 1.5 & inch & Digital & $200 P S 1 G$ & $\begin{array}{l}\mid \text { Full Port Ball } \\
\perp \text { Standard Seals } \\
\end{array}$ & $\begin{array}{l}\text { Electric } \\
\text { Motor }\end{array}$ \\
\hline HS -19 & $\mathrm{CO}_{2}$ Makeup Line Solenoid Valve & 0.5 & inch & Digital & 850 PSIG & $\begin{array}{l}\text { I } \mathrm{CO}_{2} \text { Service } \\
\perp \text { Solenoid } \\
\end{array}$ & Solenoid \\
\hline HS - 20 & $\mathrm{CO}_{2}$ Tank Cooling Solenoid Valve & 0.5 & inch & Digital & $100 \mathrm{PSIG}$ & $\begin{array}{l}\text { Law Pressure } \\
\text { | Solenold } \\
\end{array}$ & Solenoid \\
\hline$H S-21$ & Water to Slurry Tank & & & Digital & 850 PSIG & & \\
\hline HS- 22 & Slurry Tank to Slurry Pump Valve & 1.5 & inch & Digital & 200 PSIG & $\begin{array}{l}\text { Full Port Ball } \\
\text { L Standard Seals }\end{array}$ & $\begin{array}{l}\text { Electric } \\
\text { Motor }\end{array}$ \\
\hline
\end{tabular}


TABLE 7.1.4-3

CONTROL ' VALVE LIST (continued)

IVALVE L DESCRIPTION

\begin{tabular}{|l|l|l|l|l|l|l|}
\hline FCV-01 & Water to Slurry Tank Flow Valve & 2.5 inch & Analog & $100 \mathrm{PSIG}$ & & Pnuemat la/ \\
\hline DClaphragum
\end{tabular}


The plant area occupies approximately $371.6 \mathrm{~m}^{2}\left(4000 \mathrm{ft}^{2}\right)$, not including a separate control room which is elevated $3.65 \mathrm{~m}$ (12 feet) and located adjacent to the operating area. The control room is atr condttioned, which preciudes computer and instrumentation contamination with coal dust.

Arrangement is such that the product, refuse, and coal feed are serviced by a fork $1 \mathrm{fft}$ or front loader from the site materlals handling area adjacent to the building roller door. The bulk $\mathrm{CO}_{2}$ storage tank and the raw coal storage are located outstde the butlding. System makeup $\mathrm{CO}_{2}$ is piped to the pressurtzer from the tank. Additional building ventllation $\mathrm{w}+11$ be installed to prevent $\mathrm{CO}_{2}$ butldup should a major $\mathrm{CO}_{2}$ leak occur.

The plant is designed for operation by three technictans. One will be stationed in the control room to monitor operation, while a second will tend the raw coal feed. The product drum and refuse drum removal in the matertal handling area will require a third operator. Also, a shift supervisor and instrumentation spectalist are requtred.

The following discussion of the plant refers to the components and their arrangement, as shown in the P\&I diagram (Figure 7.1.3-1), Preliminary Plant Arrangement Plan (Figure 7.1.5-1) and Elevations (Figure 7.1.5-2), and the Grinding Systems Elevation (Figure 7.1.5-3).

\section{Feed Coal Preparation}

Feed coal Preparation consists of a coal bin, crusher, weight indicator, wet grinder, slurry sump, coal/water slurry pumps, and the appropriate valves, cyclone classifier, feed storage, instrumentation, and controls. Here the coal is ground to 200 mesh for feed supply.

The coal/water slurry feed system employs pressurized recycle water. Maintaining the recycle water at high pressure reduces the substantial amount of absorbed $\mathrm{CO}_{2}$ lost if the water were decompressed. 


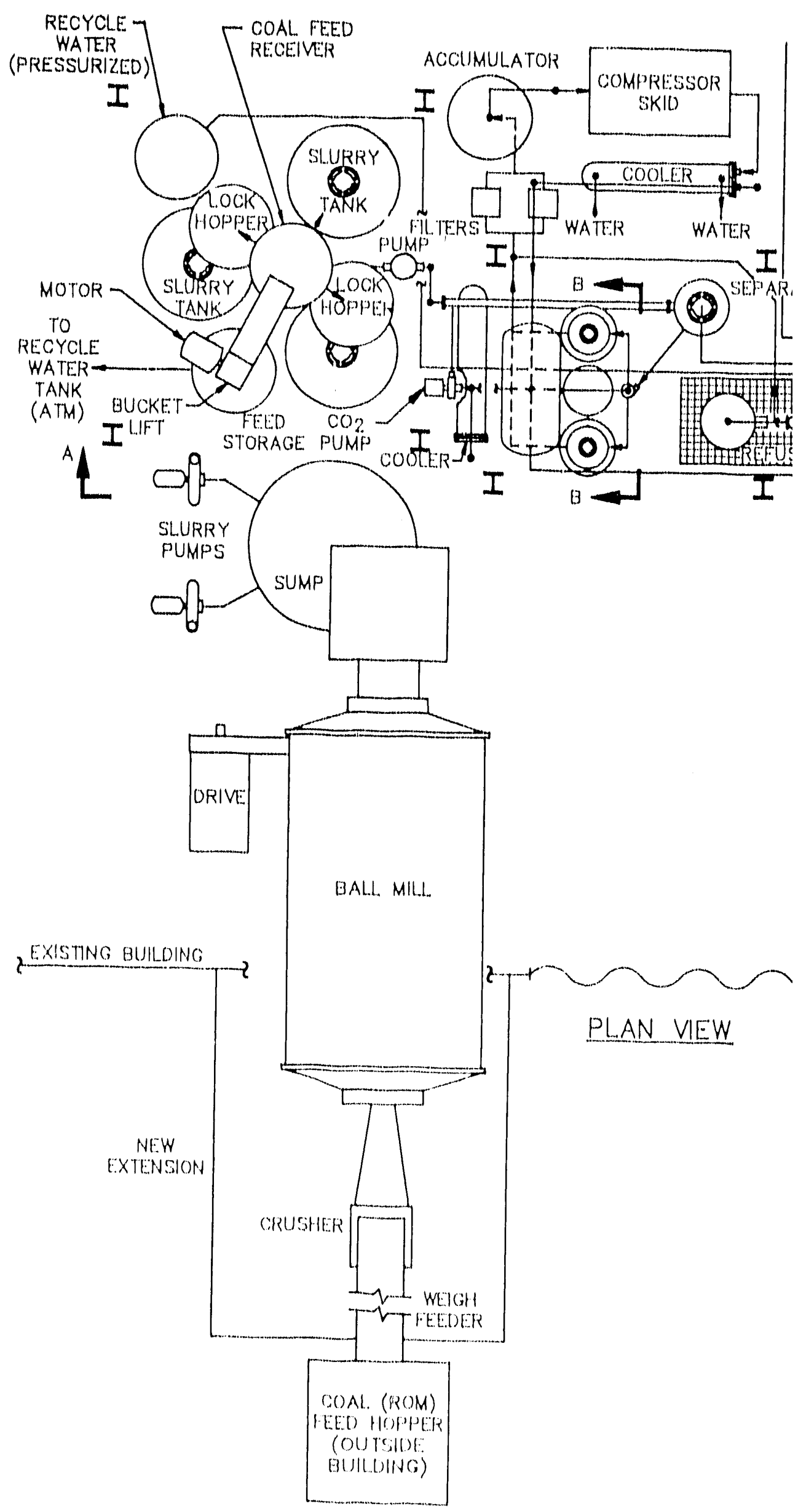




\section{LICADO, 1 TON/HOUR PROOF OF CONCEPT PLANT PRELIMINARY PLANT ARRANGEMENT, WALTZ MILL SITE}

,TOR

EXISIING WALL.

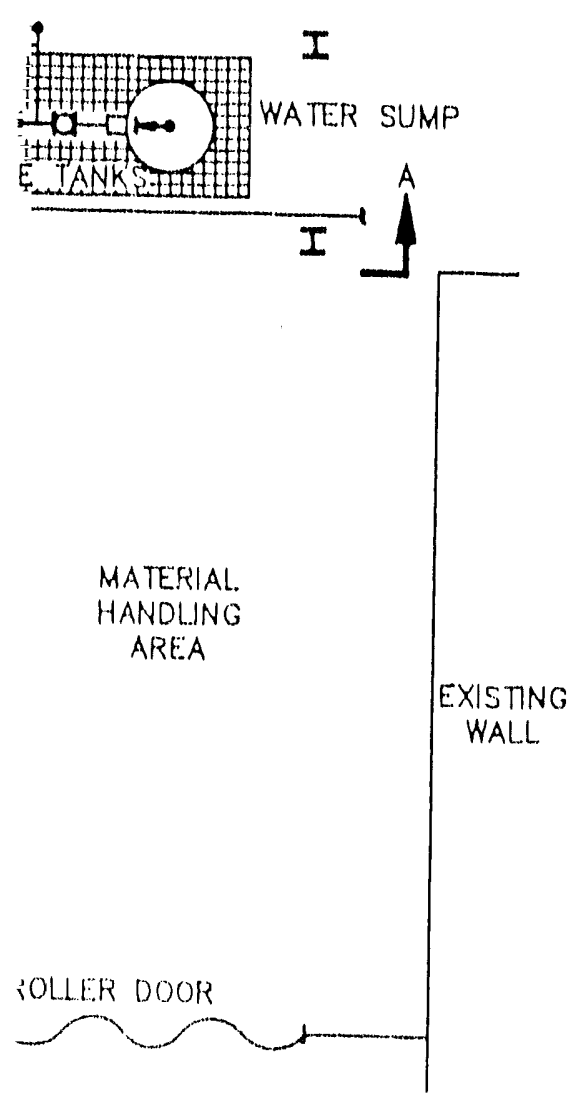

PRESSURIZER

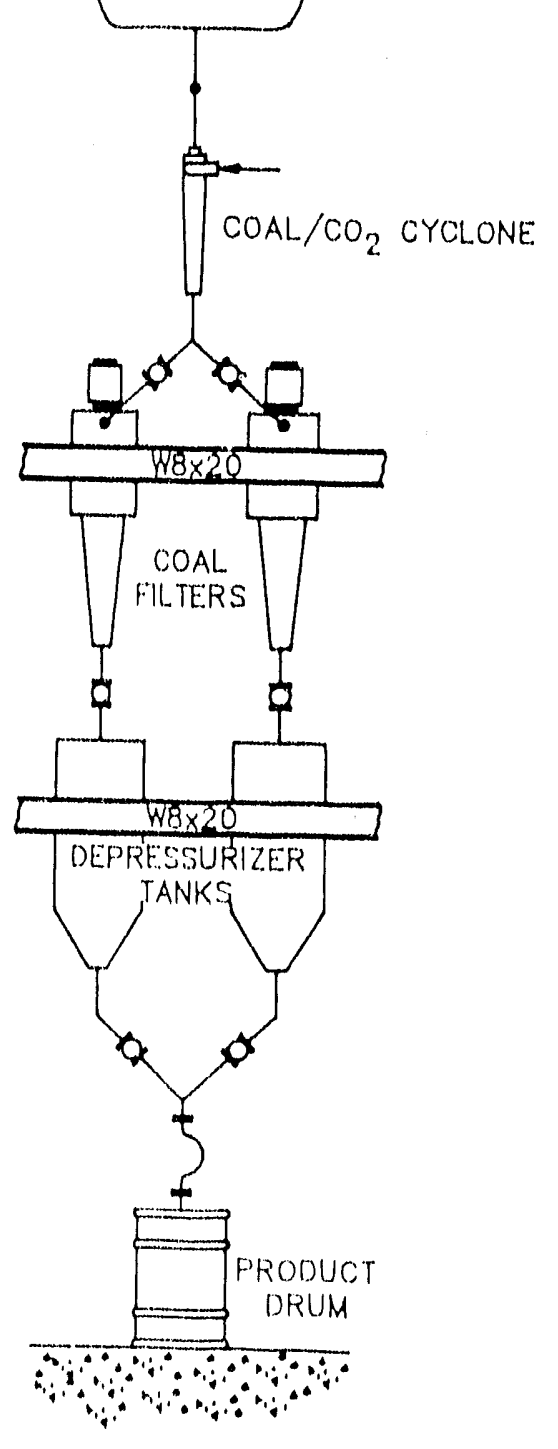

SECTION B-B 


\section{LICADO, 1 TON/HOUR PRC PRELIMINARY PLAN WALTZ MI}

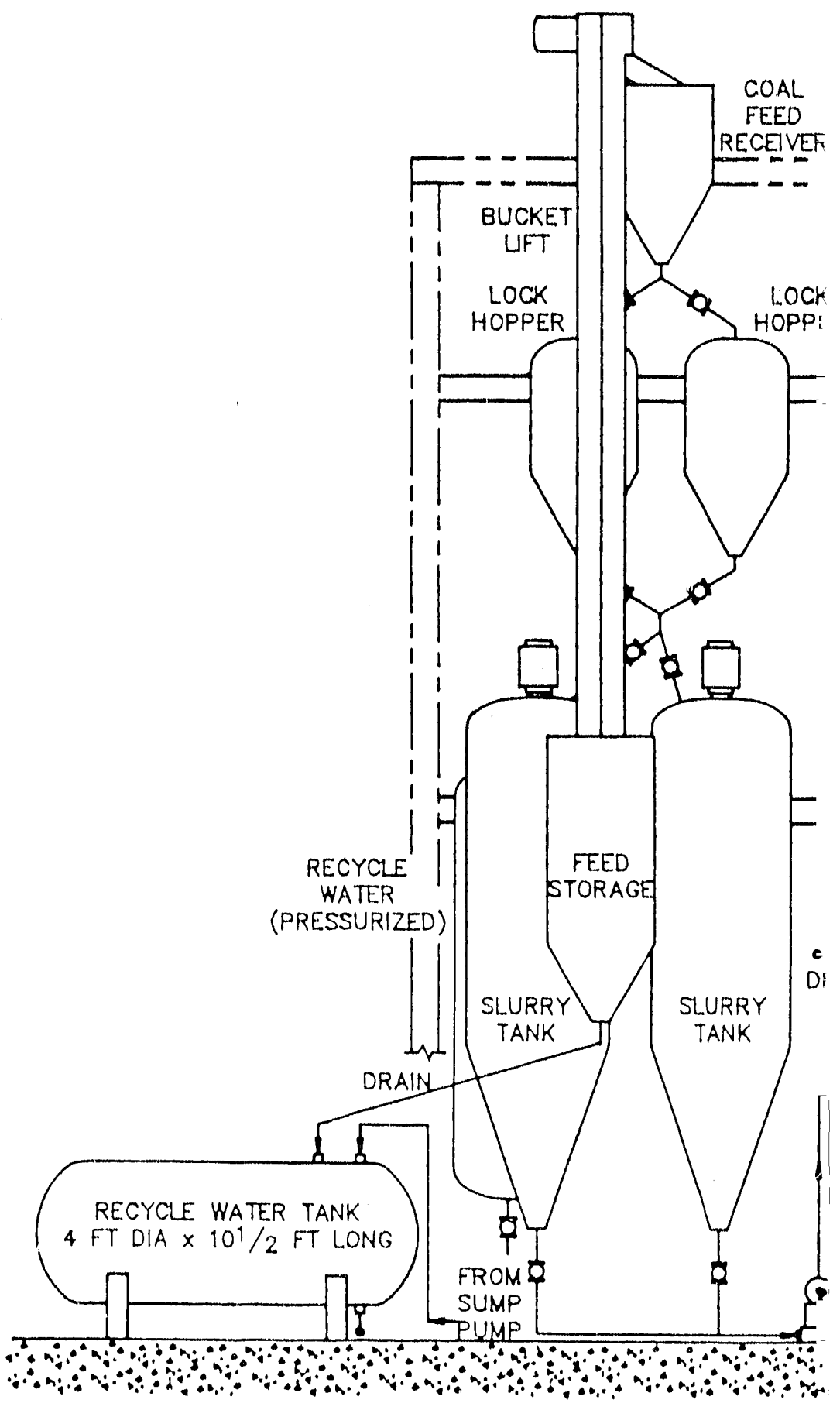

SECTION 


\section{OF OF CONCEPT PLANT}

\section{ARRANGEMENT,}

\section{SITE}

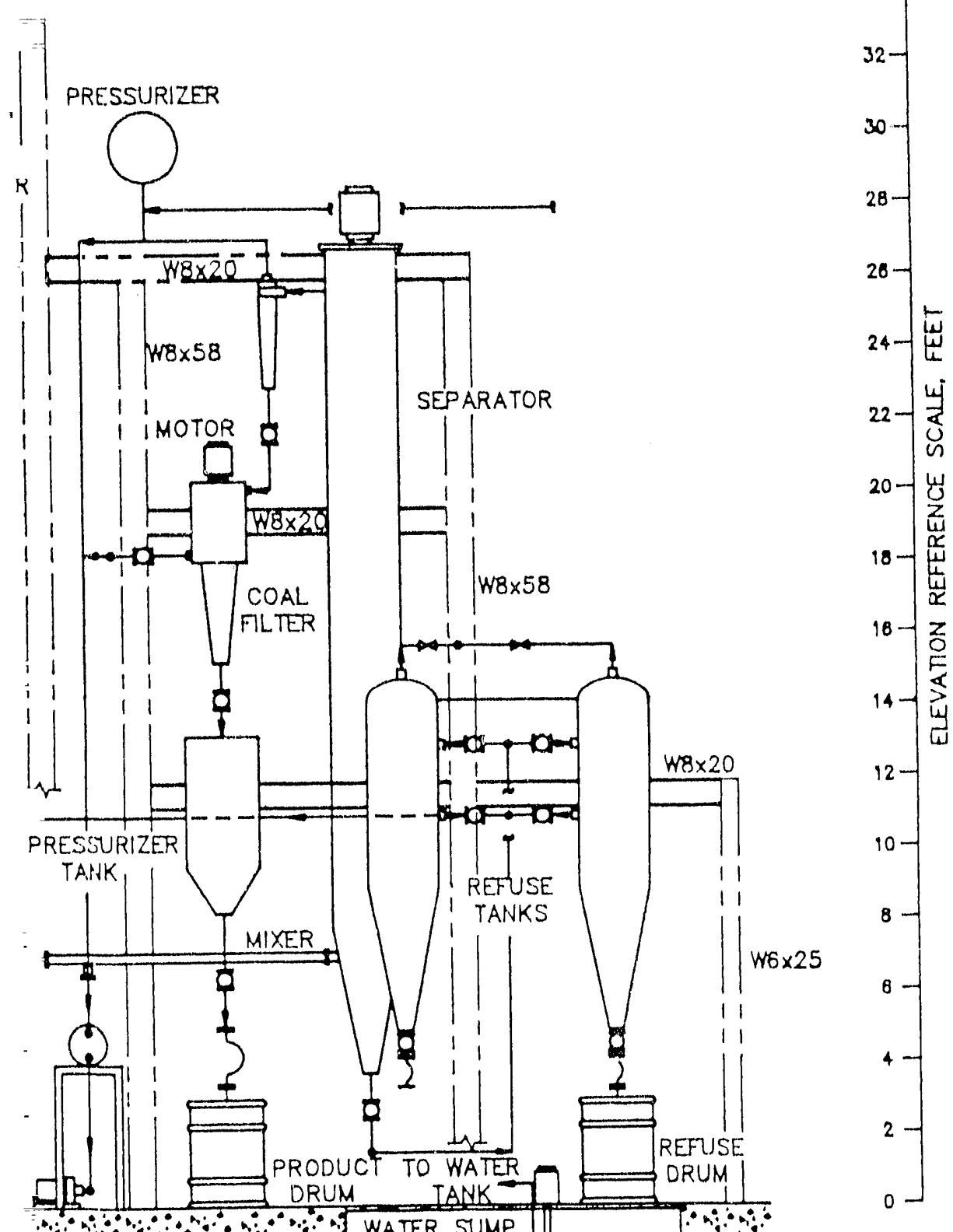

$A-A$

$\cos 20100-4$

Figure 7.1.5-2 


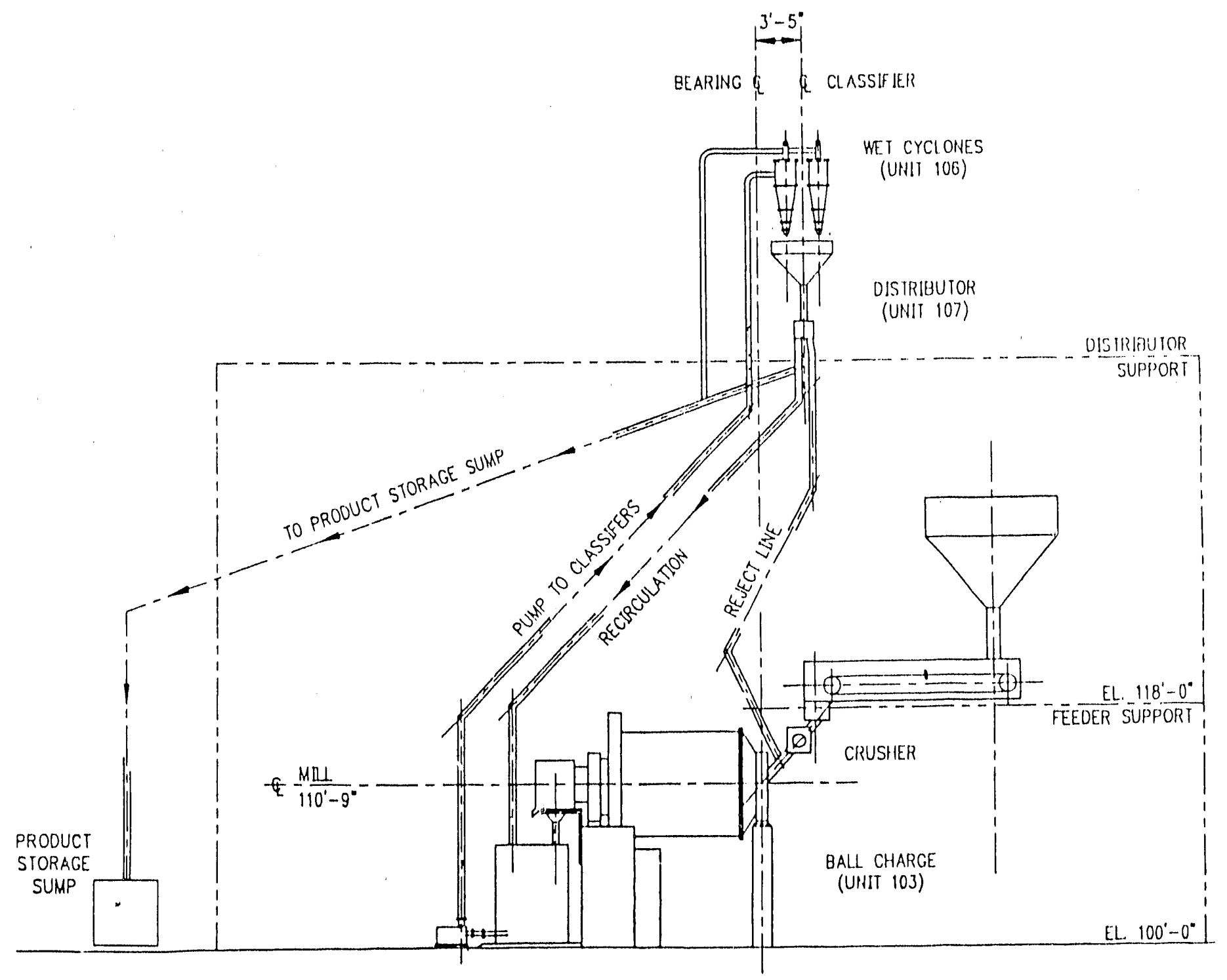

Figure 7.1.5-3. Grinding Systems Elevation 
Some components of the pressurized water feed system require multiples based on plant requirements of 0.91 metric ton ( 1 ton $/ \mathrm{hr}$ ) coal feed slurry concentration of $10 \%$ weight solids, $6.89 \times 10^{6}$ Pascals (1000 psi) pressure, and vessel fabrication constraints of keeping the wall thickness between 2.54 to $5.08 \mathrm{~cm}$ ( 1 to 2 inches).

A bucket lift delivers the fine coal to the Coal Feed Receiver which is at atmospheric pressure. Coal passes into one of two Lock Hoppers through a pipe and ball valve. The Lock Hoppers hold a 40 minute feed coal supply. Each may feed coal to any of three slurry tanks which hold a 20 minute slurry supply at about $5.79 \times 10^{6}$ Pascals $(840$ psig). Mechanical mixers keep the coal/water slurry homogeneous in the on-stream tank, while the slurry pump drains the tank and supplies the hydraulic mixer.

\section{Liquid $\mathrm{CO}_{2}$ Processing}

The liquid $\mathrm{CO}_{2}$ Processing Loop pump circulates subcooled liquid $\mathrm{CO}_{2}$ at approximately $5.93 \times 10^{6}$ Pascals $(860 \mathrm{psig})$ and $21.1^{\circ} \mathrm{C}$ $\left(70^{\circ} \mathrm{F}\right)$ through the hydraulic mixer, $\mathrm{CO}_{2} /$ water separator, $\mathrm{CO}_{2}$ clean coal filter, and $\mathrm{CO}_{2}$ loop cooler. Insulation covering the subsystem in conjunction with the $\mathrm{CO}_{2}$ cooler allows loop temperature control. A pressurizer maintains $\mathrm{CO}_{2}$ saturation pressure at about $5.79 \times 10^{6}$ Pascals ( $840 \mathrm{psig}$ ) through a temperature control system.

In the Hydraulic Mixer, liquid $\mathrm{CO}_{2}$ first contacts the coal/water slurry, as shown in Figures 7.1.5-4 and 7.1.5-5. Coal/water slurry enters along the axis of the mixer pipe while the liquid $\mathrm{CO}_{2}$ is injected into the water slurry through a multiholed nozzle. The $733.1 \mathrm{~mm}$ (one-eighth inch) diameter streams degrade to droplets due to the drag created on the $\mathrm{CO}_{2}$ stream by the difference in velocities of the coal/water and liquid $\mathrm{CO}_{2}$. This mixture of coal/water $/ \mathrm{CO}_{2}$ droplets flows through a series of orifice disks which further promote turbulence and thoroughly mix the stream. Orifice plates are of two patterns and alternate along the length of the mixer. The first plate has four $1.91 \mathrm{~cm}(3 / 4$ inch) holes, and the second plate has a $6.35 \mathrm{~cm}$ (2-1/2 inch) wide cross. 

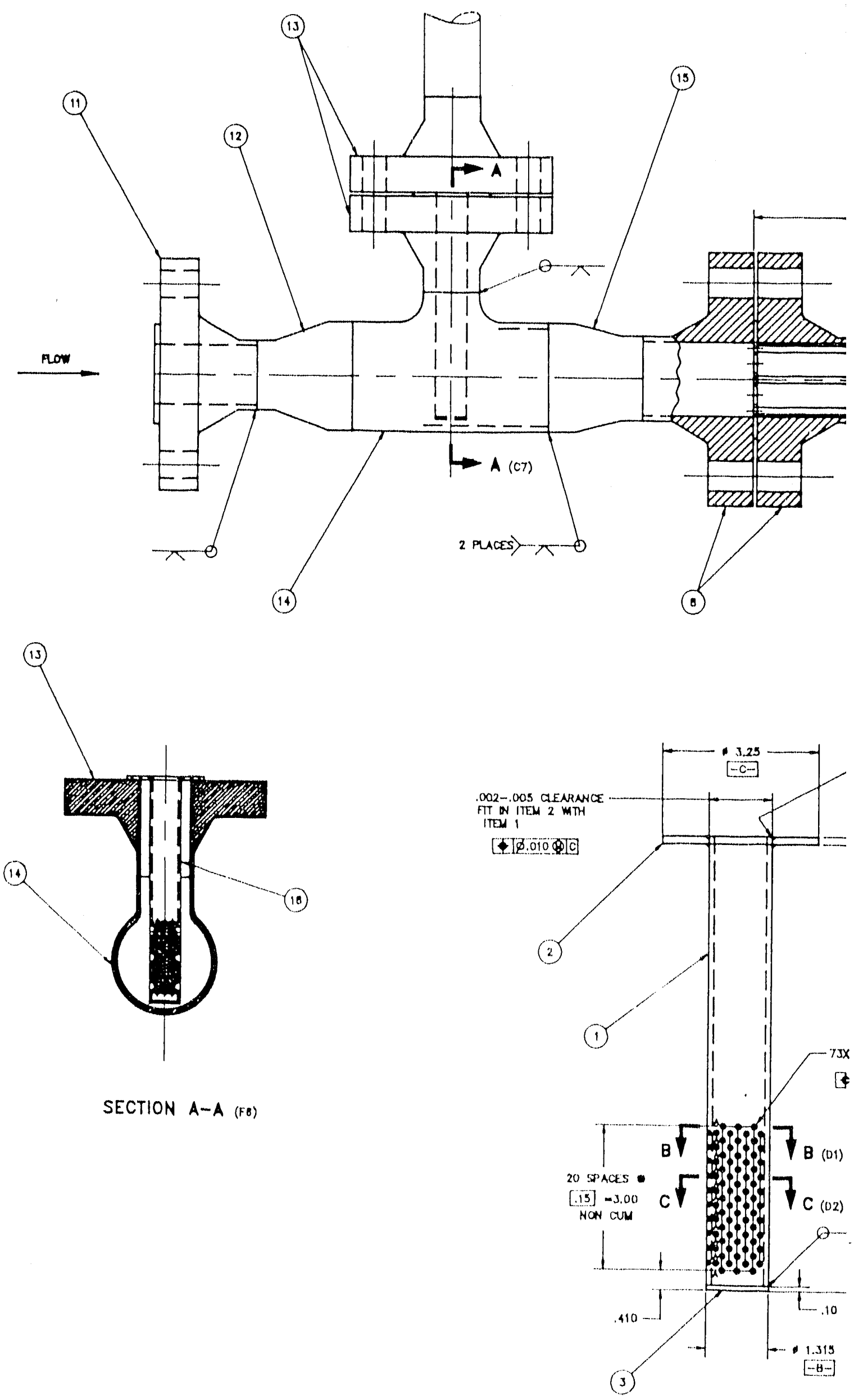

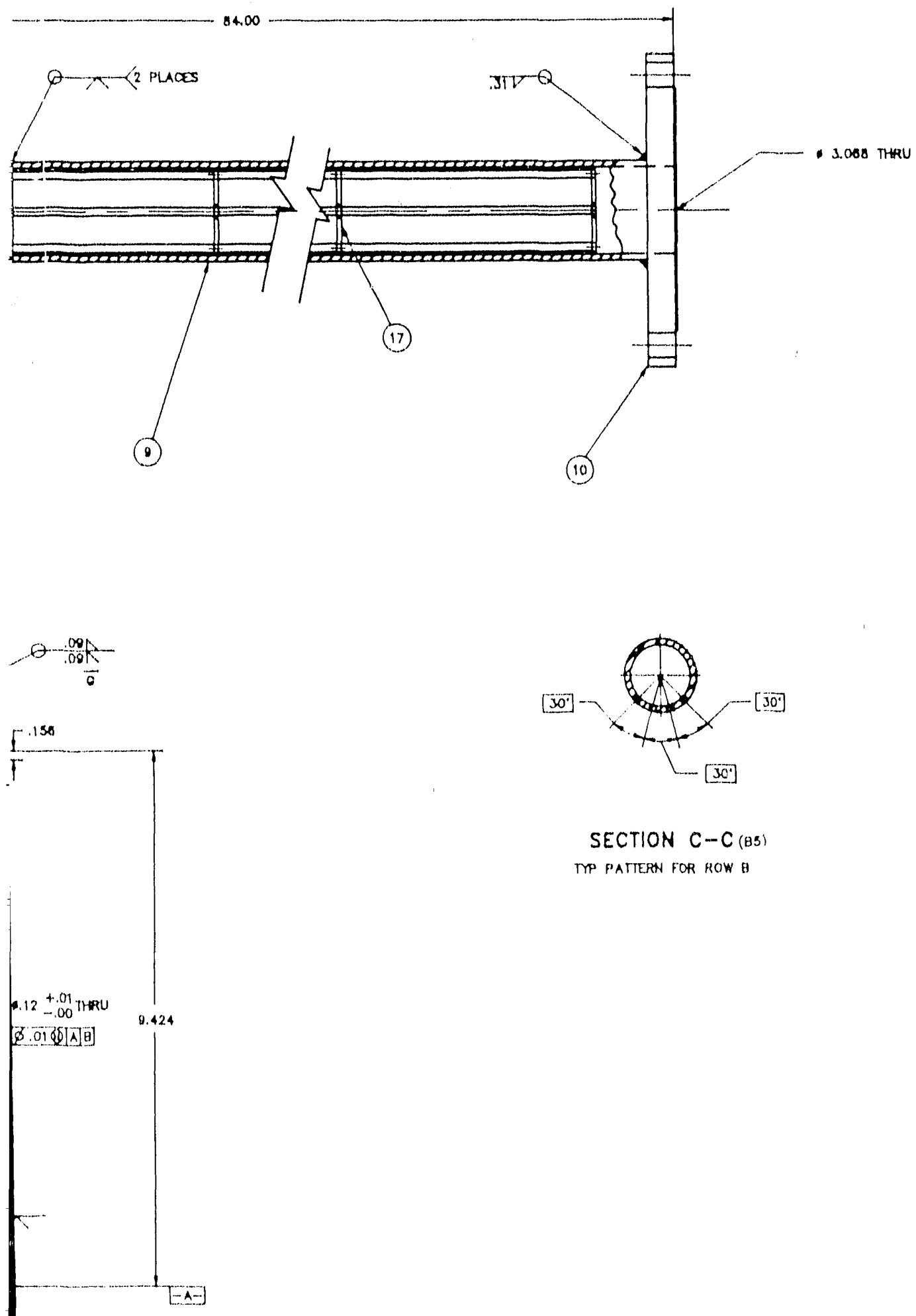

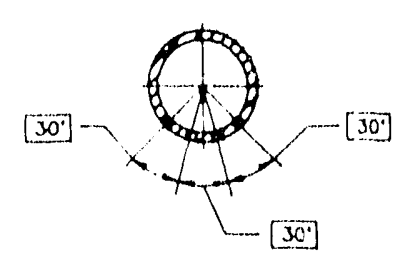

SECTION C-C (BS)

MP PATIERA FOR ROW A

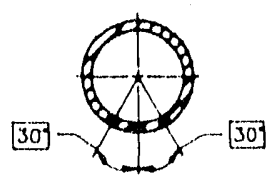

SECTION B-B (CB)

ITP PATTERN FOH ROW A
HYORAULIC LINE MIXER

Figure $7.1 .5-4$ 


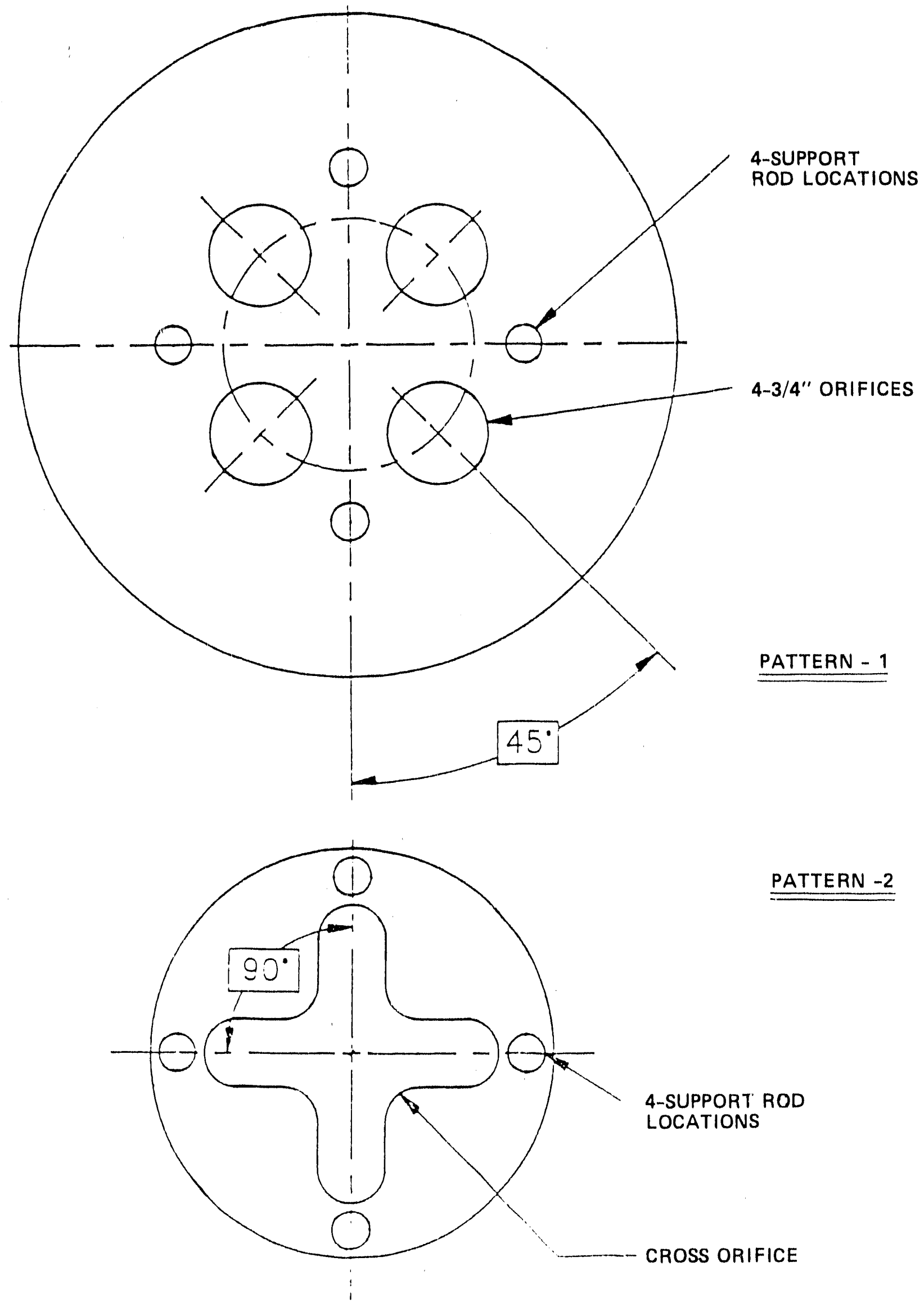

Figure 7.1.5-5. Mixer Orifice Details 
Figure 7.1.5-6 is the preliminary design and layout drawing for the integral multistage separator. The unit has four separation stages within one pressurized column. The separator column has a pressure shell of $61 \mathrm{~cm}$ (24 inch) 0.D. Schedule 40, 304 stainless steel pipe $6.71 \mathrm{~m}$ (22 feet) long. The column bottom is a steep conical section with a center discharge to facilitate fluid flow with a high solids concentration.

The $\mathrm{coa} 1 / \mathrm{CO}_{2}$ exits the column through two diametrically opposed pipes $50.8 \mathrm{~cm}$ (20 inches) below the unit top. Water containing refuse and pyritic sulfur issues from the bottom. The raw coal/water $/ \mathrm{CO}_{2}$ feed nozzle is approximately $1 / 3$ the distance up the column.

The top of the column is closed by a $600 \mathrm{lb}$. blind flange from which all of the column internals are supported or pass through. A11 of the internals are removed from the column when the top flange is raised.

Each stage consists of a conical flow tube through which the mixture of coal/water $/ \mathrm{CO}_{2}$ is accelerated by a propeller at the lower and larger diameter end. Also, attached to the lower or base end of the conical flow tube is a tubular ring with eight small holes directed toward the center of the cone and propeller. Either $\mathrm{CO}_{2}$ or water may be injected through these holes to enhance coal/refuse separation. The mixer velocity, as it passes through the conical flow tube, will be increased by four items and be discharged at $45^{\circ}$ toward the column periphery. The heavier refuse/water will travel further and concentrate near the column wall, while the lighter $\mathrm{coal} / \mathrm{CO}_{2}$ will remain nearer the center of the column. Stages are separated by a quiescent zone.

All mixing blades may be positioned along a single central shaft driven from above through a magnetic coupling to the externally mounted motor. 


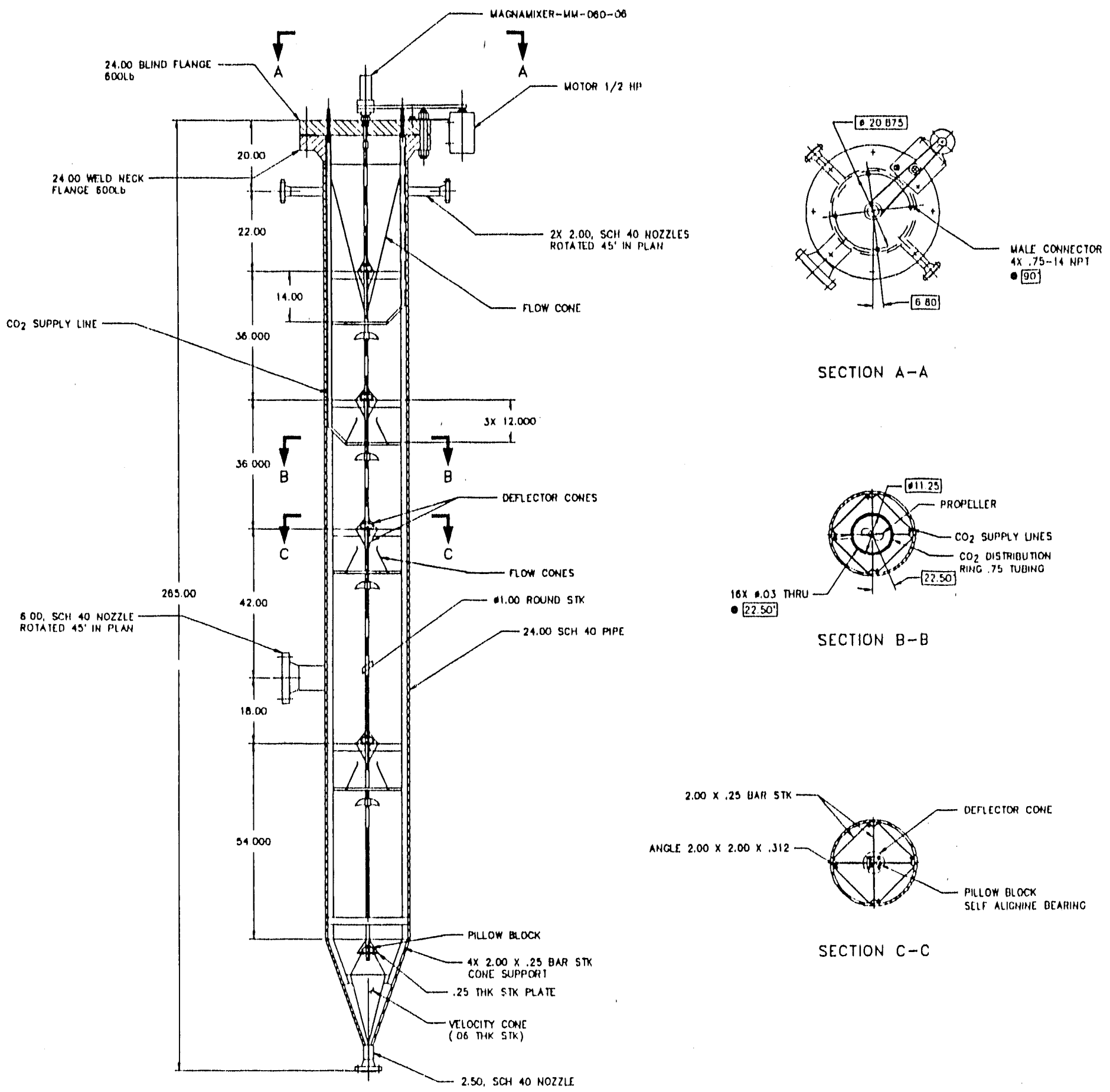

CC900201-1

Figure 7.1.5-6. Integral Multistage Separator 


\section{Cleaned Coal Recovery}

Cleaned coal and $\mathrm{CO}_{2}$ exit the top of the separators (approximately $12 \%$ wt. solids). The coal/ $\mathrm{CO}_{2}$ slurry flows through a cyclone into the auger filters (Figure 7.1.5-7), operating at saturated condtitions. The feed slurry liquid level is maintained in the fliter medium auger leg while saturated vapor is above the liquid in the remaining auger leg and in the vertical coal recetver leg. The auger is constantly turning at 1 to 3 RPM, stripping coal from inside the filter medium and delivering it to the top of the unit where it falls into the coal receiver leg. The coal in each filter is cyclically discharged into the Product collection Vessel (Depressurizer Tank), in which it is depressurized. The $\mathrm{CO}_{2}$ goes to a $\mathrm{CO}_{2}$ Accumulator while the clean coal is packaged in drums; however, in a commercial operation, the product will be pneumatically transported to large storage silos.

Filtrate (1iquid $\mathrm{CO}_{2}$ ) from the filters is dellvered to the $\mathrm{CO}_{2}$ loop pressurtzer.

\section{Refuse Disposal}

Refuse and water are constantly drawn from the bottom of the separator, at about $3-4 \%$ wt. solids concentration, through a level control valve and into a cyclone separator within the Refuse Letdown Tank. Water with absorbed $\mathrm{CO}_{2}$ vents at the top of the cyclone and concentrated refuse at the bottom. Expanded $\mathrm{CO}_{2}$ vents to the recycle subsystem while the water is decanted from over the refuse and passes to the pressurized recycle water tank. While the first tank is filling, refuse settling, and water being decanted, the second is discharging refuse sludge from the bottom for disposal.

Both the product and refuse tanks are duplifated to assure continuous plant operation by switching from Tank 1 after filling to Tank 2. 


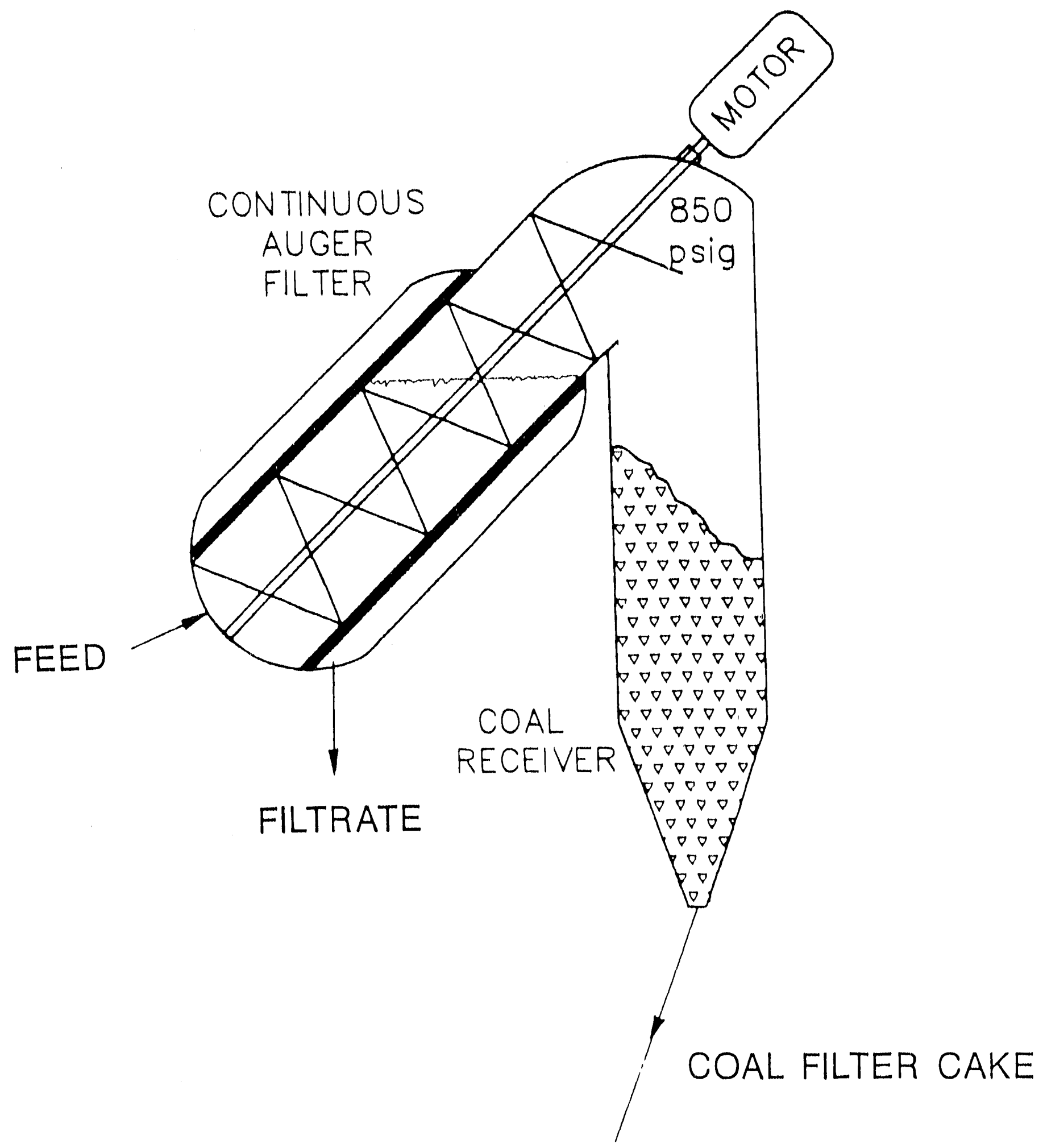

Figure 7.1.5-7. Continuous Auger Filter 
Gaseous CQ Recycle

In this and larger p1ants, some $\mathrm{CO}_{2}$ w 111 accompany the refuse and product in the depressurtzing operation. Economics requtre that this gaseous $\mathrm{CO}_{2}$ be compressed and recycled to the liquid $\mathrm{CO}_{2}$ 10op. The gaseous $\mathrm{CO}_{2}$ subsystem contatns fllters, accumulator, compressor, and after-cooler.

\subsubsection{Plant Operation}

Run of mine coal is loaded into the hopper outside the butlding and is fed onto a weigh feeder inside the butlding at the rate of 1 ton/hour. The feeder conveys the raw coal to a crusher where it is reduced to $1 / 4$ inch and smaller. A bal1 mill wet grinds the $0.63 \mathrm{~cm}(1 / 4 \mathrm{fnch})$ coal to a 200 mesh top size and discharges it into a sump from which a slurry pump delivers the coal fines to a wet cyclone classifier. The overflow from the cyclone carries the 200 mesh and smaller particles to feed storage, while the cyclone underflow returns oversized matertal to the ball mill.

From the feed storage, where the excess water drains back to the atmospheric recycle water tank, a bucket conveyer $11 \mathrm{fts}$ the 200 mesh top size coal to the top of the building and deposits them into the feed recelver. The feed receiver supplies two lock hoppers, each sized to hold a 40 minute supply. Ball valves isolate the feed recetver from the lock hoppers to allow pressurization of the lock hoppers with $\mathrm{CO}_{2}$ saturated vapor. From this point, the slurry tank, refuse letdown tank, coal depressurizer, and recycle water tank are interconnected with a pressure equalization system, which is connected to the vapor space in the pressurizer and maintains these vessels at $\mathrm{CO}_{2}$ saturation pressure of $5.79 \times 10^{6}$ Pascals $(840 \mathrm{psig})$ at $21.1^{\circ} \mathrm{C}\left(70^{\circ} \mathrm{F}\right)$. However, each tank may be isolated from the equalization system, if desired. 
There are three slurry tanks, each holding a 20 minute process feed supply. While Tank 1 is on-stream, Tank 2 is mixing and Tank 3 is being fllled. To fill a tank, water ts first fllled to a prescrtbed level, the stirrer turned on, and then the contents of a lock hopper is deposited into the slurry tank. The concentration may be changed by controlling the amount of coal added.

A slurry pump increases the feed pressure to approximately $6.21 \times$ $10^{6}$ Pascals $(900 \mathrm{psig})$ to supply the hydraultc mixer. Liquid $\mathrm{CO}_{2}$ is injected into the slurry within the mixer. The mixer has a sertes of eight orffice plates through which the coal/water $/ \mathrm{CO}_{2}$ mixture passes. Pressure drop through the mixer is calculated to be approximately $3.44 \times 10^{5}$ Pascals (50 psi).

The mixture enters the separator which has four stages, each of which separate and concentrate the $\mathrm{coa} 1 / \mathrm{CO}_{2}$ and water/refuse phases of the prevtous stage.

The coal/ $/ \mathrm{CO}_{2}$ phase concentrates near the center of the column and exits the unit at the top, while the heavter water/refuse phase accumulates at the column periphery and exits at the bottom of the column.

Slurry pump flow rate plus the $\mathrm{CO}_{2}$ flow rate give the total separator "in" flow, whlle the "out" flow is balanced by control of the water/ refuse stream exit rate through the bottom $\mathrm{CO}_{2}$ /water interface level indication. Thus, the remaining coal/ $/ \mathrm{CO}_{2}$ "out" flow is automatically established.

Water, refuse, and absorbed $\mathrm{CO}_{2}$ are drawn from the bottom of the separation vessel and into the liquid cyclone within one of the two Refuse Letdown Tanks. Concentrated solids exit from the bottom of the cyclone, while water and absorbed $\mathrm{CO}_{2}$ vent from the top. Solids will concentrate in the tank bottom while water is decanted from over the refuse and 
returned to the pressurized recycle water tank. When a prescribed soltds level is reached in the on-1 ine tank, it will be isolated from the system; and flow will be diverted to the second tank. $\mathrm{CO}_{2}$ will be vented to the accumulator from the first tank to reduce its pressure to about $1.72 \times$ $10^{5}$ pascals $(25 \mathrm{psig})$. This pressure will be used to force the refuse sludge out of the vessel into disposal drums.

At some time during operation of the plant, runs will be made to investigate continuous venting of refuse sludge and recycle water from one tank only; thus, the second tank will be held in reserve.

The same procedure will be used for the coal depressurizing tanks.

The product stream ( $12 \%$ solids, $\left.\mathrm{coal} / \mathrm{CO}_{2}\right)$ from the top of the separator is concentrated in a cyclone to about $25 \%$ solids before it enters one of two auger filters. The second filter is a standby unit. Any coal fines in the overflow are recirculated to the separator with the $\mathrm{CO}_{2}$ flow.

Coal cake is delivered by the auger to the receiver leg and flows through into the depressurizer tank. At a prescribed level in the depressurizer tank, it is isolated from the system; $\mathrm{CO}_{2}$ is vented to the accumulator until the tank has 10 psig remaining. Then this pressure is used to fill the product drums. Meanwhile, the coal filter cake continues to fill the receiver leg of the filter until the emptied receiving tank is put back into the system, at which time the cycle is repeated.

\subsubsection{Required Development}

Two areas which require development for success of the LICADO process are, 1) an efficient means for separating the two liquid phases $\left(\mathrm{CO}_{2}\right.$ and water), and 2) recovery of product from the process. These are presently 
being examined in the Bench Research Unit and the Continuous Research Unit. Dewatering of the refuse is required also; however, conventional dewatering technologies will be applied.

\subsubsection{Separator}

The conceptual design for the separator should be tested in the Continuous Research Unit to demonstrate its expected performance improvement compared to a single-stage separator. The effectiveness of the design and parametric variation should be assessed before the 0.9 metric ton/hr ( 1 -ton/ hour) unit is finalized. Separator parameters such as mixture residence time, effect of fluid velocities within the separator; mechanical mixer speed, blade placement and relative size; necessity for the mechanical mixer; need for and location of $\mathrm{CO}_{2}$ injection ports in the separator; need for and location of water injection ports; and optimum location of coal $\mathrm{CO}_{2}$ /water ash irtarface will be investigated.

The preliminary design for these components will be updated, based on the test results from the scaled unit during final design.

\subsubsection{Product Recovery (Coal/ $/ \mathrm{CO}_{2}$ Separation)}

High pressure filtration is necessary to remove the liquid $\mathrm{CO}_{2}$ from the cleaned coal; and to date, only multiple candle-type filters cycling in a batch mode will provide the required capacity for a commercial plant. However, these candle filters are very expensive and potentially could require extensive maintenance. Therefore, it is necessary that a continuous high pressure filter be developed. The auger filter, Figure 7.1.5-7, is a good candidate for further investigation. However, if difficulty is encountered during scale-up to a commercial size, an alternative would be a moving belt filter within a pressure housing similar to Figures 7.1.7.2-1 and 7.1.7.2-2. 


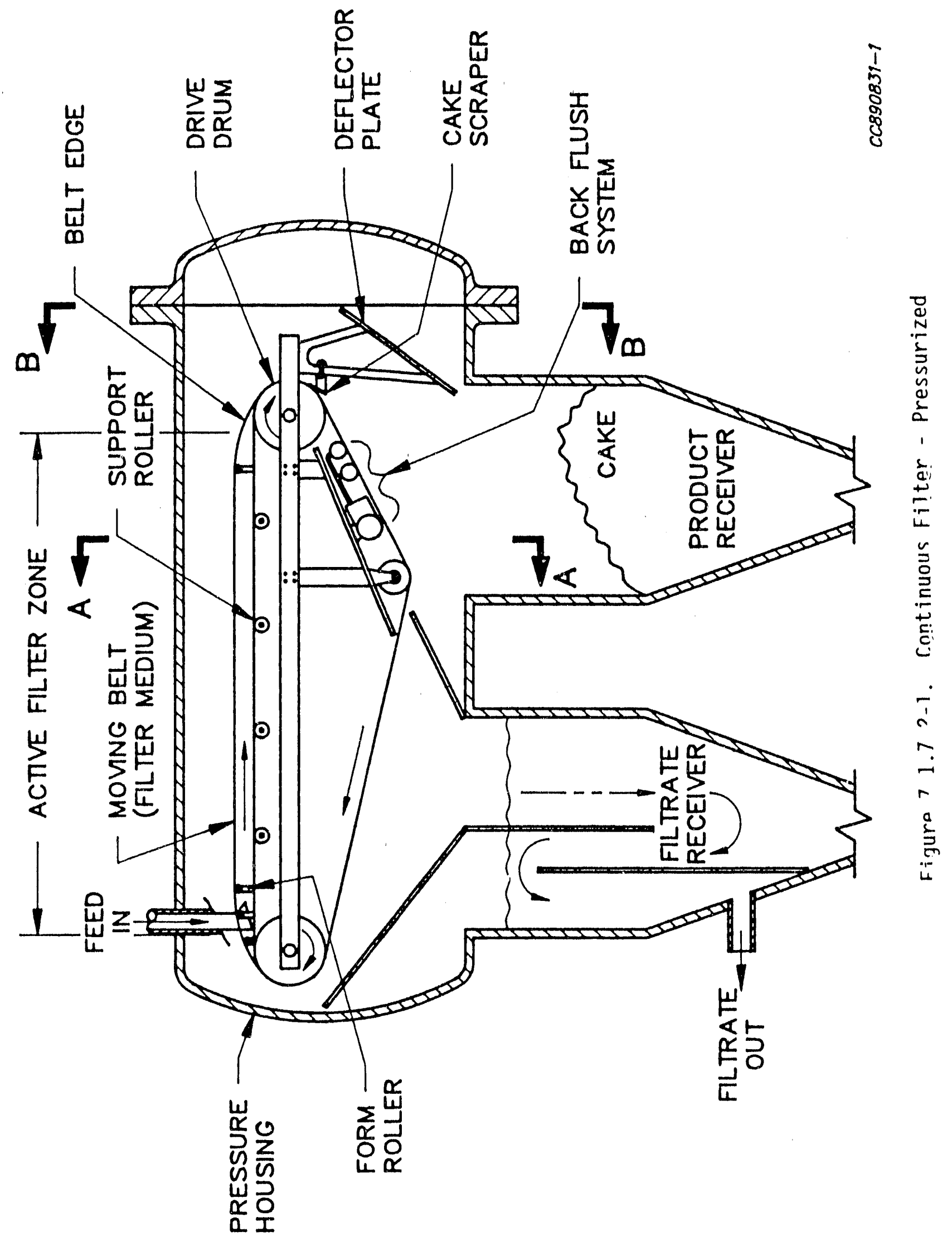



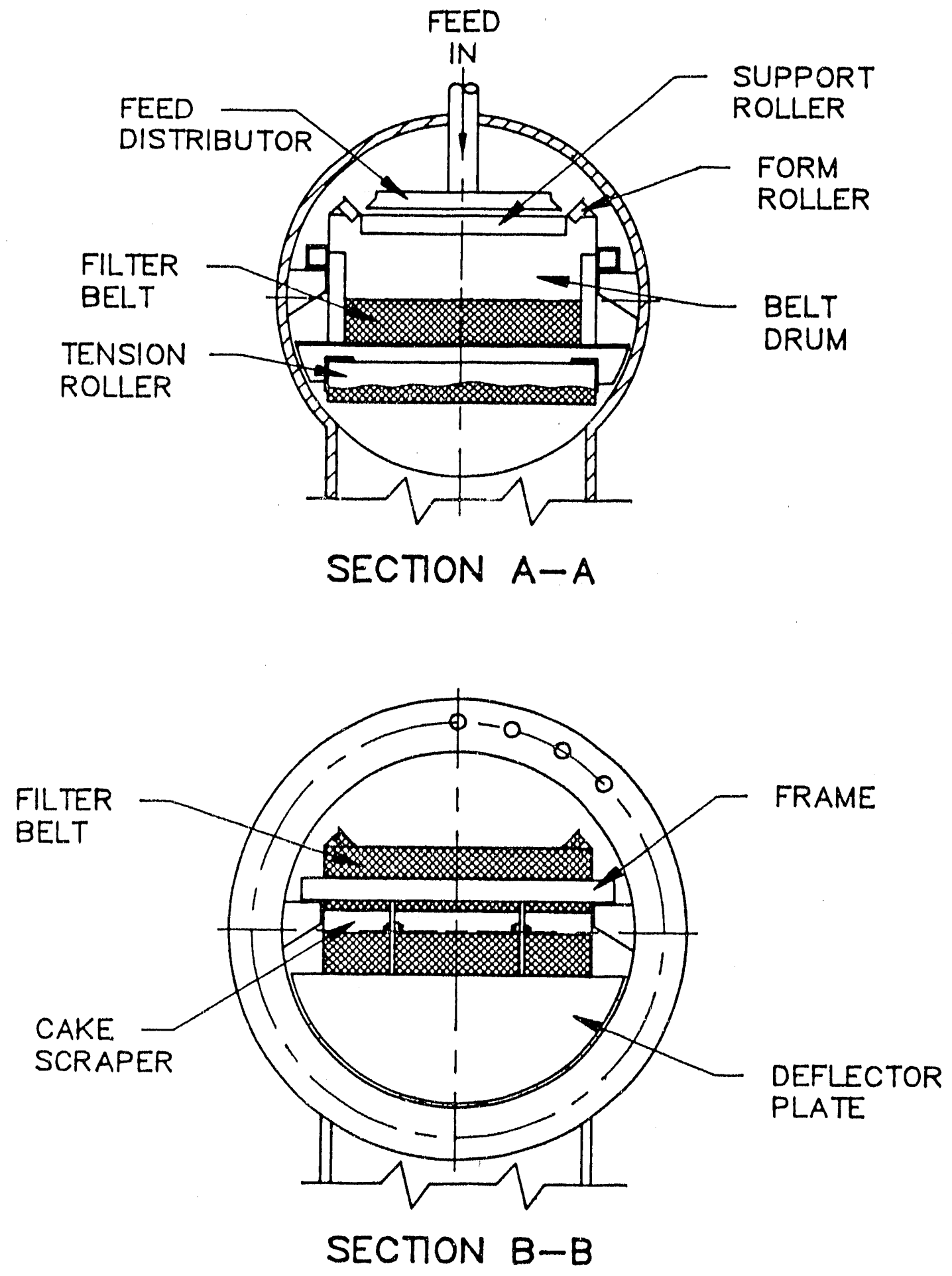

C6890831-2

Figure 7.1.7.2-2. Sections $A-A$ and $B-B$ 


\subsubsection{Conceptual Design Review of POC Plant}

A conceptual design review was held on July 13, 1989 at the Westinghouse Large, PA site. The review material presented was a condensed version of Section 7.1 of this report, "Proof-of-Concept Plant (1 Ton/Hour)."

The significant design modifications resulting from the review are:

- Dry grind the coal in a $\mathrm{CO}_{2}$ atmosphere.

- Add a "Super Scalper" to remove slate and rock from the ROM coal before it is ground.

- Specify apex of cyclone to prevent plugging by coal particles. The apex diameter should be at least three times the largest particle diameter.

- Provide for individual operation of subsystems to check out and start-up the plant. These modifications will be implemented during the preliminary design phase.

A summary discussion of the significant questions is presented in Appendix 7.1.8.

\subsection{Commercial Plant (200 Ton/Hour)}

A commercial size plant was conceived to provide 181 metric ton/hr (200 ton/hour) of product feed for a $500 \mathrm{MW}_{\mathrm{e}}$ utility. This concept was used to provide a budgetary capital cost estimate that was input to the economic evaluation presented in Section 8.0. 
The system and flow schematic for the commercial plant was based on the 0.9 metric ton/hr LICADO Proof-of-Concept system. From the 181 metric ton/hr schematic and material balances, plant components were sized; and a budgetary capital cost estimate was developed.

\subsubsection{Requirements}

The plant is designed to meet the requirements and assumptions which follow:

- The production rate is 181 meiric tons/hr for cleaned coal $(90 \% \leq 200$ mesh)

- Feed material ROM bituminous coal from Upper Freeport seam

- Cleaned coal ash content will be less than $2.0 \%$

- Approximately $90 \%$ of the pyritic sulfur will be removed

- Feed is available in feed hopper, and product is ready for transport

- Feed coal/water slurry $20 \%$ wt. solids

- $\mathrm{CO}_{2}$ slurry ratio is 0.5

- Coal residence time in separator is five minutes

- Utilities are site available 
- All process wetted containment material is 304 stainless steel

- Vesse1 wall thickness is $\leq 5.72 \mathrm{~cm}(2-1 / 4$ inches $)$

- Based on the discussion previousiy presented in Section 7.1.2.2, it is assumed that the auger filter is developed; and this component is used in this plant concept

\subsubsection{Discussion of System (Figure 7.2.2-1)}

The LICADO process system is basically the same as discussed in Section 7.1 , with the exception of the feed coal preparation step. In the commercial plant the coal size reduction ball mill is air swept; and air is used to transport the coal fines to the classifier and bag house. This will be modified by replacing with a closed gaseous $\mathrm{CO}_{2}$ system, which may be accomplished at minimal cost.

Also, this plant's separator allows refuse settling and concentration to approximately $19 \%$ solids in the bottom of the separator, with pressurized water being decanted for recycle before the refuse slurry exits to the refuse cyclone for further concentration. In the POC plant, refuse exits the separator at about $3-1 / 2 \%$ solids as it enters the cyclone. The assumption for this plant is that separator development will allow this approach.

\subsubsection{Description of Plant}

Raw coal is processed through one of five 49.5 metric ton/hr (55-ton/hour) feed preparation stations. From the rail car it passes through a coal hopper, to a weight feeder, and into an air swept Ball Mill. Crushed coal 


\section{LICADO, 200 TON/HOUR COI}
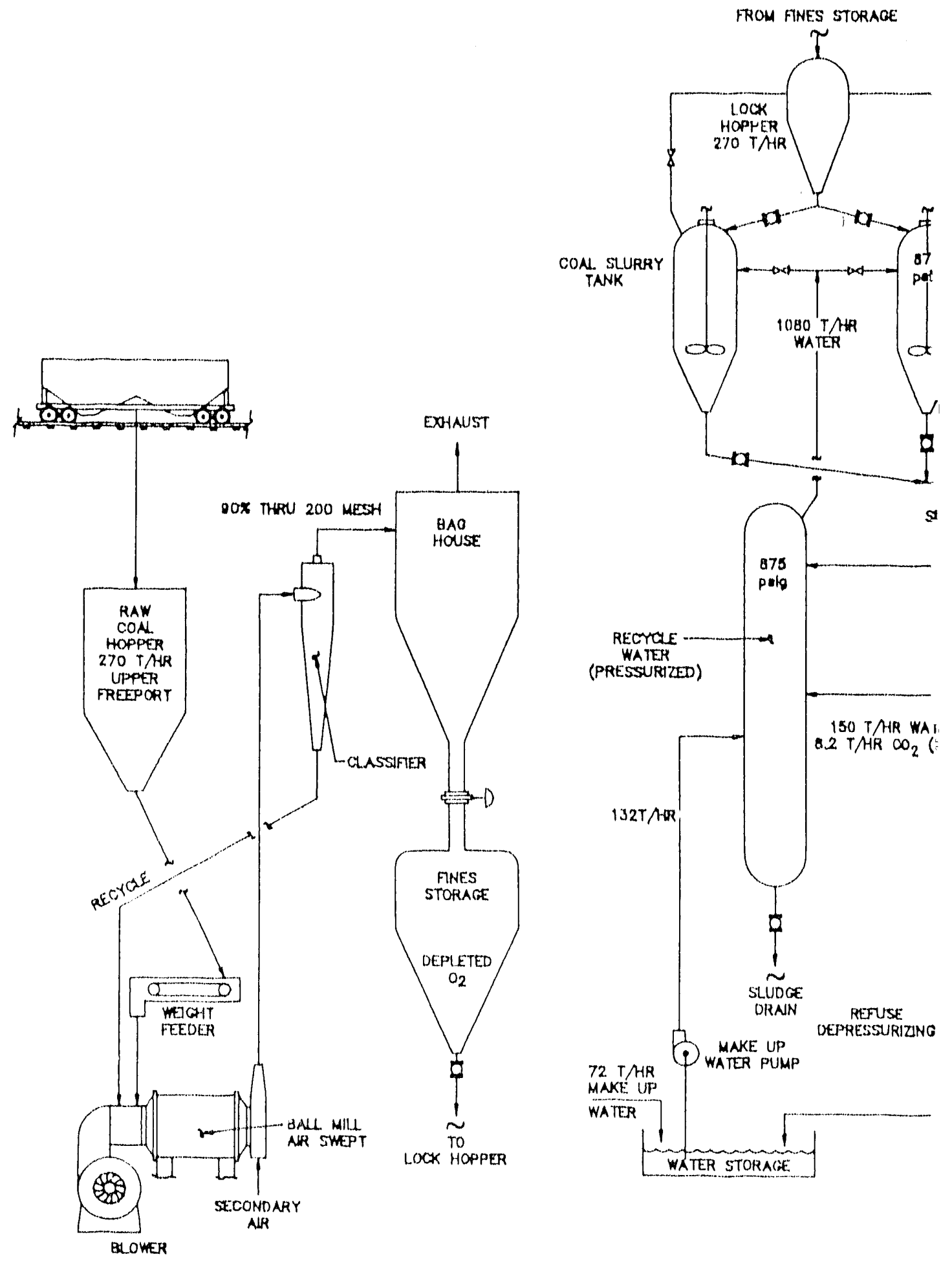


\section{IMERCIAL PLANT FLOW SCHEMATIC}

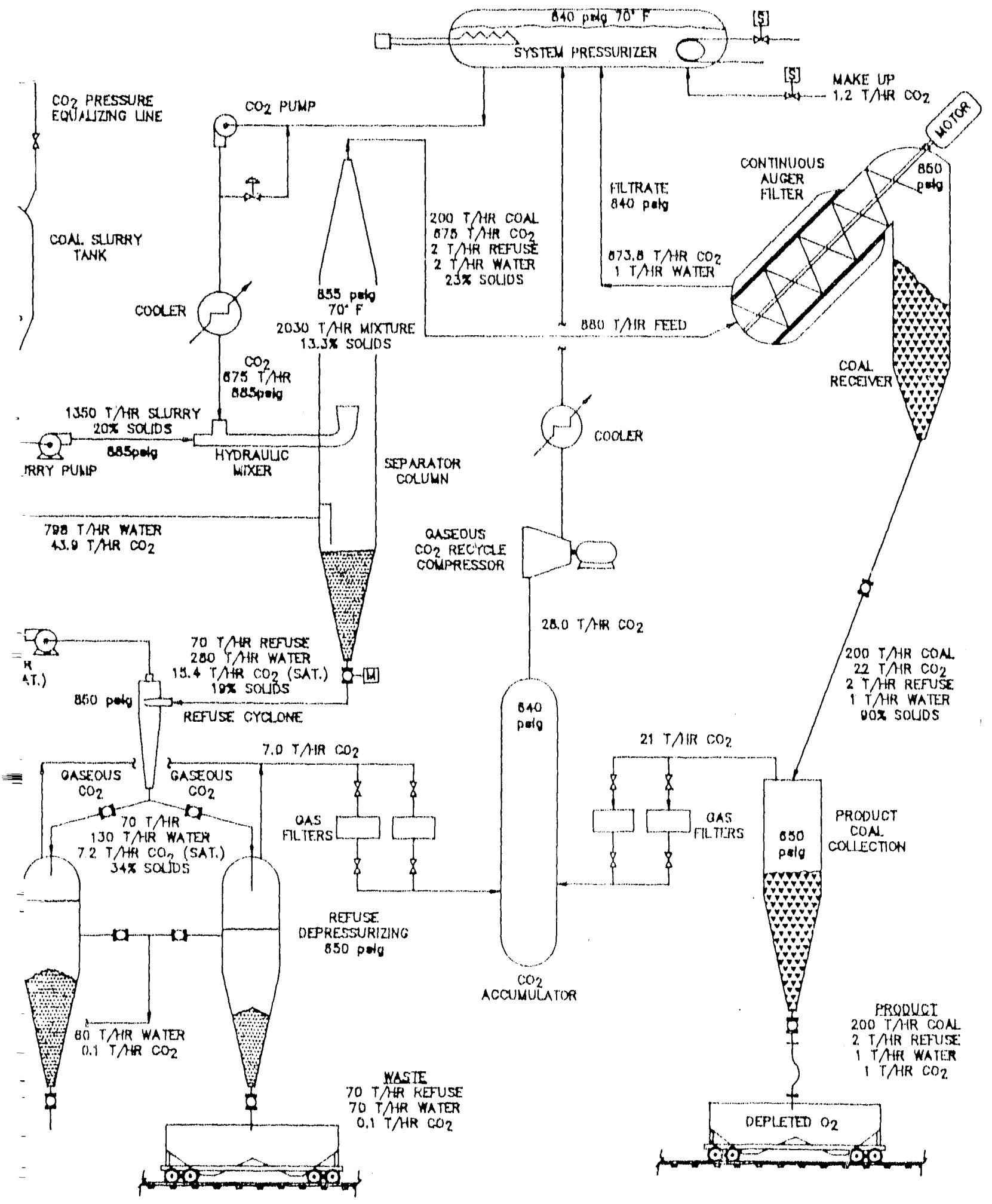

$00890505-1$

Figure 7.2.2-1 
is classified in a cyclone with bottoms (1arger than 200 mesh) returning to the Ball Mill, and the 200 mesh and smaller material passing through a Bag House and into a Fines Storage Vessel which has an oxygen depleted atmosphere.

Coal fines pass from storage into one of two Lock Hoppers. Ear. Lock Hopper may feed one of two Coal slurry Tanks and cycles between them. The pressure is equalized between the Lock Hopper and one Slurry Tank which contains high pressure $\mathrm{CO}_{2}$, and then the coal fines flow into the Slurry Tank. The tank is filled to a prescribed level with high pressure water (saturated with $\mathrm{CO}_{2}$ at about 5.8\%), isolated, and stirring initiated.

When the slurry is homogeneous, the slurry pump sends a $20 \% \mathrm{wt}$. solids water slurry to all four Hydraulic Mixers where liquid $\mathrm{CO}_{2}$ is intimately mixed with the slurry. Each Hydraulic Mixer is connected to one Separator column. Within the column, $\mathrm{CO}_{2}$ containing coal rises; and the refuse remains with the water and sinks. Residence time in the separator is five minutes.

Refuse and water are constantly drawn from the bottom of the separator at a 19 wt. \% solids concentration. Part way up the column, water is decanted from the concentrated refuse and stored in two Recycle Water Vessels. Meanwhile, the refuse stream is further concentrated in a Refuse Cyclone, with the overflow water going to the Recycle Water Vessels and the concentrated refuse ( $34 \mathrm{wt}$. \% solids) alternately filling one of the three Refuse Depressurizer Tanks. Again, water is decanted from the settled sludge and is sent to atmospheric water storage. The water may be filtered to remove waste particles entrained in the cyclone underflow, or it may be recirculated with these particles. The settled refuse paste (approximately 50\% wt. solids) is forced from the bottom of the vessel into disposal cars. If necessary, flocculents may be used to achieve 
these solids concentrations in the waste. While the first tank is filling, the second tank is settling and its water is being decanted; and the third is discharging refuse paste from the bottom into the cars.

Cleaned coal and $\mathrm{CO}_{2}$ exit the top of the separators (23\% wt. solids). The coal $/ \mathrm{CO}_{2}$ slurry flows through a desliming cyclone (not shown) into the auger filters (16 units) operating at saturated conditions. The feed slurry liquid level is maintained in the filter medtum auger leg, while saturated vapor is above the liquid in the remaining auger leg and in the vertical coal receiver leg. The auger is constantly turning at one to three RPM, stripping coal from inside the filter medium, and delivering it to the top of the unit where it falls into the coal receiver leg. Four filters are connected to one Product coal collection Vessel. The coal in each filter is cyclically discharged into the Product Collection vessel in which it is depressurized. The $\mathrm{CO}_{2}$ goes to two $\mathrm{CO}_{2}$ accumulators, while the clean coal flows to a closed rail car with depleted oxygen atmosphere.

Filtrate (1iquid $\mathrm{CO}_{2}$ ) from the filters is delivered to the process system pressurizer.

Gaseous $\mathrm{CO}_{2}$, at approximately $4.41 \times 10^{6}$ Pascals $(640$ psig) from the accumulators, is recompressed in a recycle compressor to $5.79 \times$ $10^{6}$ Pascals $(840 \mathrm{psig})$, cooled to $21.1^{\circ} \mathrm{C}\left(70^{\circ} \mathrm{F}\right)$, and returned to the process system pressurizer.

The system pressure is maintained at saturated conditions $21.1^{\circ} \mathrm{C}$ $\left(70^{\circ} \mathrm{F}\right)$ and $5.79 \times 10^{6}(840 \mathrm{psig})$ by automatic temperature control of the pressurizer through heating or cooling. 


\subsubsection{Budgetary Cost Estimate}

The fixed capital cost was based on a method presented in Reference 7-1 and is used in the process industry to provide budgetary plant costs. Equipment and component costs are estimated, and then the remaining direct and indirect costs are calculated as a factor of that cost. The factors are based on historical data of chemical process plants, which were modifled because of the high capital cost of this plant resulting from the costly grinding system and high pressure, stainless steel vessels. This approach was also used to provide the costs of Reference 2.

Vessel and tank fabricators were contacted; and a cost per pound of metal was obtained for code stamped vessels built to the ASME Pressure Vesse1 Code, Section VIII and made of 304 stainless stee1. The cost estimates of standard equipment and components were provided by manufacturers and suppliers. The total of these costs were considered as Primary Equipment costs and used as the basis for estimating the remaining direct and indirect Fixed Capital costs.

The total Fixed Capital cost for the commercial 181 metric ton/hr (2.30-ton/hour) LICADO plant is $\$ 94,580,500$. This cost (breakdown presented in Appendix $G$ ) is used in the economic studies presented in Section 8.0.

In this estimate for the fixed capital cost, there was no cost allocated for 1 and or buildings because it was assumed outdoor construction would be used for the equipment on land furnished by the host coal mine or utility. Space for the control room was assumed to be avallable in existing buildings. Other factors, such as engineering and supervision and process contingencies, were estimated at about one-half the values used in previous studies because of the high capital cost of the equipment for this plant. Without this reduction, the costs for these factors would have been overestimated. 


\subsection{Waste Stream Recovery Plant (50-Ton/Hour)}

A modified process was conceptually designed which used $\mathrm{CO}_{2}$ for coal benefictation differently than it is used in the LICADO process. In the LICADO process, suffictent $\mathrm{CO}_{2}$ is used to form a coal-rich liquid $\mathrm{CO}_{2}$ phase separate from the refuse-rich water phase. The $\mathrm{CO}_{2}$ and water phases are separated, and the coal is then removed from the $\mathrm{CO}_{2}$ phase.

In the modified process, just enough $\mathrm{CO}_{2}$ is used to bridge or agglomerate the coal fines into particles which are larger than the refuse fines. The refuse fines are not affected and remain with the water phase. The mixture is then screened, and the coal agglomerate stays on the screen while the water with refuse passes through the screen.

Tests of the modified process were made with several coals in the 2 -inch diameter batch system, which demonstrated the feasibility of this approach. This work is described in Section 3.3 of this report. Promising results were obtained with 111 inois No. 6 coal, which is hydrophilic, as coal wastes may become after extended storage in water.

A conceptual design of a 45 metric ton/hr (50-ton/hour) plant was developed to be used as the basis for a budgetary cost estimate and comparison with the LICADO process. Feed to this 50-ton/hour plant is assumed to be the waste stream from a commercial coal washing plant and contains about $3 \%$ wt. solids in water. The coal feed was based on Upper Freeport coal with approximately $25 \%$ wt. refuse.

\subsubsection{Requirements}

The plant is designed to meet the requirements and assumptions which follow: 
- Feed ts 45 metric ton/hr (50-ton/hour) of $3 \%$ wt. solids from a waste stream of a Commercial coal washing plant

- Feed is bituminous coal from the Upper Freeport seam at $\leq 200$ mesh

- The plant $w 111$ be designed for $50 \%$ ash rejection and $70 \%$ yield

- Feed coal/water stream concentrated to $20 \% \mathrm{wt}$. solids before $\mathrm{CO}_{2}$ contact

- $20 \%$ wt. $\mathrm{CO}_{2}$ per weight of coal used in process

- Limited water saturation with $\mathrm{CO}_{2}$ at high pressure due to short residence time

- Coal residence time in separator is one minute

- Utilities are site available

- All process wetted containment material is 304 stainless steel

- Vesse1 wall thickness is $\leq 5.1 \mathrm{~cm}$ (2 inches)

- Concept sufficient to provide basis for budgetary capital cost estimate

- A pressurized moving screen continuous filter will be used for product recovery, similar to Figure 7.1.7.2-1 and -2 . 


\subsubsection{Discussion of System (Figure 7.3.2-1)}

The process appears to be simpler than the standard LICADO process, since there is no liquid $\mathrm{CO}_{2}$ phase requiring separation from the water phase.

However, should more $\mathrm{CO}_{2}$ be required than anticipated or be absorbed in the water phase, then a $\mathrm{CO}_{2}$ /water separator could be installed between the product filter and the refuse pond to reclaim the $\mathrm{CO}_{2}$.

In the laboratory, separation of the larger size coal agglomerates from the refuse/water phase by screening has been very effective. Therefore, this method of product recovery is used in the plant, assuming that a continuous belt screen contained in a pressure housing has been developed.

This plant does not recycle the process water as is done in the standard LICADO process. Separation of the refuse from the water is no longer required, and both are dumped into the on-site refuse pond. The energy of the high pressure refuse water might be partially reclaimed by driving a coal/water slurry booster pump installed up stream of the regular slurry pump.

\subsubsection{Description of Plant}

The waste stream (containing $3 \%$ solids) from a coal washing plant is concentrated to $20 \% \mathrm{wt}$. solids in a cyclone. Underflow from the cyclone goes to a slurry feed tank from which a slurry pump pressurizes the feed into a mixer in which it contacts liquid $\mathrm{CO}_{2}$ at approximately $5.89 \mathrm{x}$ $10^{6}$ (855 psig). The $\mathrm{CO}_{2}$ agglomerates the coal fines into larger particles; and the mixture of agglomerated coal, smaller particle refuse and water passes onto a moving screen which allows the refuse and water to pass through while retaining the agglomerated coal particles. This moving screen filter is contained within a pressurized vessel which incorporates a separate filtrate receiver and clean coal storage in the 


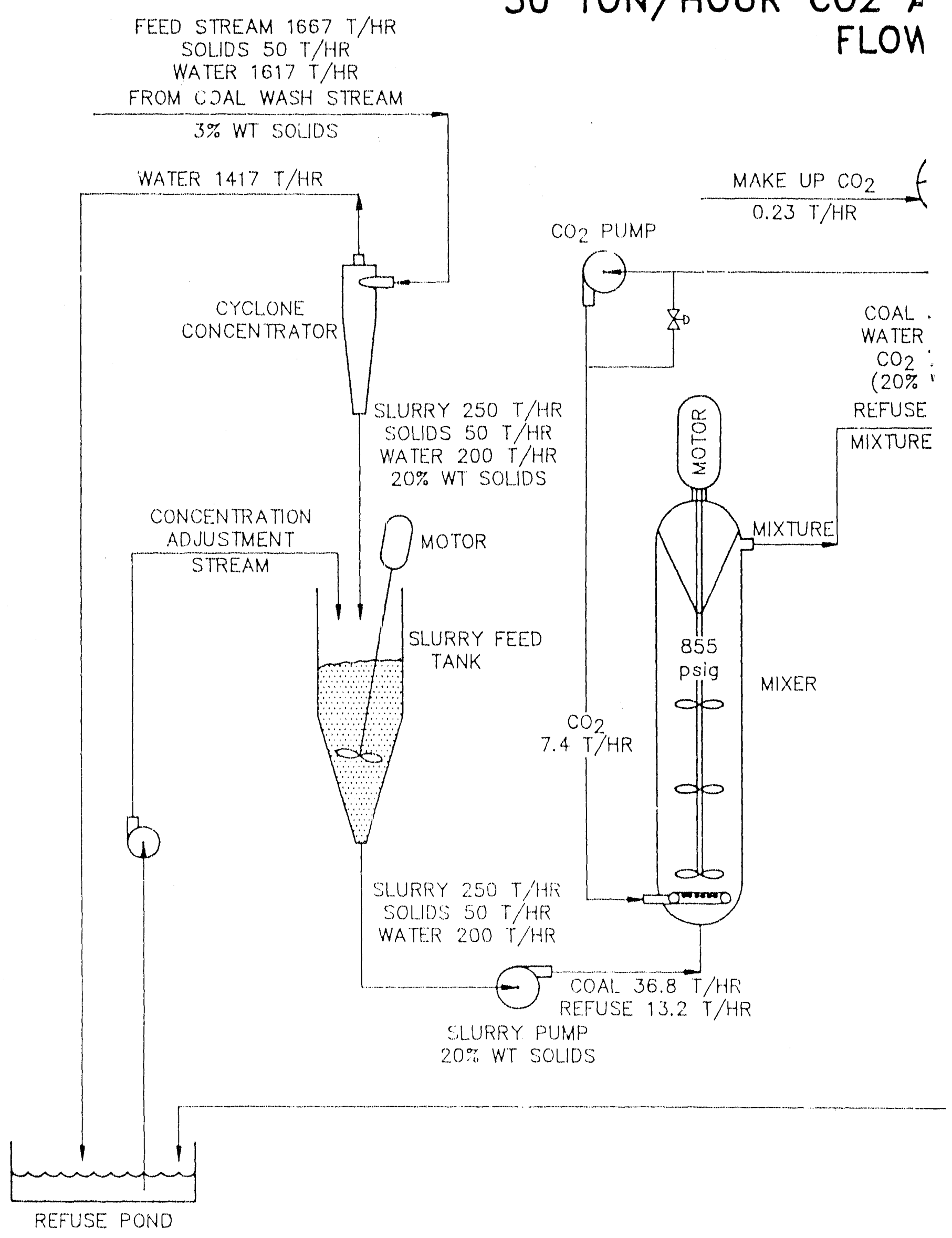




\section{;GLOMERATION PROCESS SHEET}

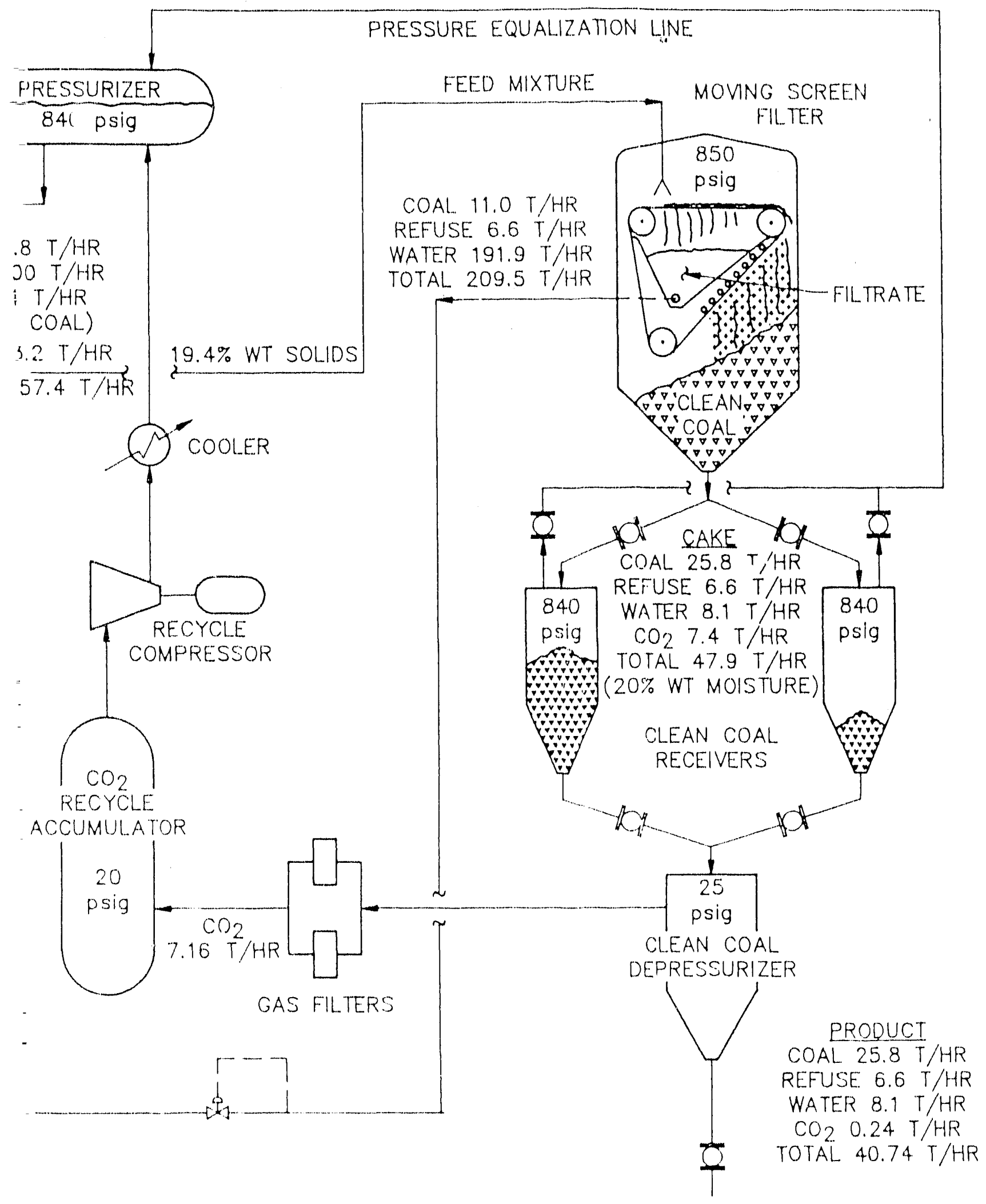


vessel bottom. Filtrate (reiuse and water) is returned to the refuse pond while the cleaned coal passes through the coal receivers into the depressurizer, and from there is ready for combustion.

Based on the requirements and the information given in Figure 7.3.2-1, the plant components were sized and a budgetary cost estimate was established for the plant.

\subsubsection{Budgetary Cost Estimate}

The same budgetary cost estimating procedure was used for this plant as is out 7 ined in Section 7.2.4.

The total fixed capital cost for the commercial 45 metric ton/hr (50-ton/ hr) Agglomeration Plant is $\$ 9,670,000$. This cost (details presented in Appendix 7.3.4) is used in the economic evaluations presented in Section 8.0. 


\section{REFERENCES}

7-1. R. Miller and E. B. Miller, Translator, "Manual of Economic Analysis of Chemical Processes," McGraw-Hill Co., New York, 1981.

7-2. "Technical/Economic Assessment of the LICADO Process", by Burns and Roe Services Corporation, for U.S. DOE Pittsburgh Energy Center, March 1986. 


\subsection{ECONOMIC STUDIES}

Economic studies of the LICADO process were made to determine the market potential for this process. Studies were made of the product sales price for two applications of this process: a 181 metric ton/hr (200-ton per hour) plant, such as would be located at a mine or utility, and a 45 metric ton $/ \mathrm{hr}$ (50-ton per hour) waste recovery $\mathrm{plant}$, which would process the fines in the waste stream from an existing conventional plant or would recover fines from a waste pond. The economics model and results of these studies are discussed in this section.

\subsection{Economic Model}

A process economics model was devaloped using a personal computer spreadsheet that calculated the required sales price per ton of coal processed by the LICADO process. This sales price was calculated from the capital cost of the plant, financing costs, taxes, return on investment, plant operating and maintenance costs, and refuse disposal costs. The sensitivity of the sales price to variations in key parameters was investigated.

This reference case parameters for the economic studies are summarized in Table 8.1-1. Sensitivity analyses were made to determine the effect upon the required sales price for variations in return on investment, capital cost, carbon dioxide usage, and plant capacity factor. An example of the program output is provided in Appendix 8-1.

\subsection{Economic Study Results}

Results of the economic studies of the 181 metric ton/hr per hour, ROM plant and the 45 metric ton/hr plant Waste Recovery Plants are discussed in this section. 
TABLE 8.1-1

PARAMETERS USED IN ECONOMIC MODEL

$\begin{array}{lcc} & \begin{array}{c}\text { Run-of-Mine } \\ \text { Plant }\end{array} & \begin{array}{c}\text { Waste } \\ \text { Recovery Plant }\end{array} \\ \text { P1ant Capacity, tons/hr } & 200 & 50 \\ \text { Capital Cost, \$M } & 95 & 12.5 \\ \text { Carbon Dioxide Usage, wt.\% of Product } & 1.0 & 2.0 \\ \text { Return-On-Investment (after taxes), \% } & 20 & 20 \\ \text { 'Taxes, \% } & 37 & 37 \\ \text { P1ant Capacity Factor (Dimension1ess) } & 0.80 & 0.80 \\ \text { Operating and Maintenance, \$M/yr } & 12.45 & 2.15 \\ \text { Plant Life, Years } & 20 & 20 \\ \text { Escalation, \% per year } & 5 & 5 \\ \text { Interest during Construction, \% } & 10 & 10 \\ \text { \% Debt } & 0.75 & 0.75 \\ \text { Long Term Interest, \% } & 12 & 12 \\ \text { Refuse Disposal Costs, } & 2.00 & 1.00 \\ \text { \$ per ton of refuse } & & \end{array}$

BREAKDOWN OF OPERATING AND MAINTENANCE COST

Run-of-Mine

Plant

Labor, $\$ M / y r$

Utilities, $\$ M / y r$

$\mathrm{CO}_{2}, \mathrm{SM} / \mathrm{yr}$

Waste Disposal, $\$ M / y r$

Replacement Equipment
3.0

6.0

0.91

1.59

$1 \%$, first 5 years

$2 \%$, last 15 years
Waste

Recovery Plant

0.92

0.188

0.595

0.318

$1 \%$, first 5 years

$2 \%$, last 15 years 


\subsubsection{ROM Plant}

Economic analyses of the 181 metric ton per hour, ROM plant, were made using the computer-based model. The plant rapital costs and operating/ maintenance costs were estimated from the plant conceptual design and flow sheet described in Section 7.2

Results of the analyses for this plant are graphically correlated in Figures $8.2-1,8.2-2$, and 8.2-3. The required sales price for the reference case was $\$ 17.10 /$ ton $(\$ 18.85 /$ metric ton) (product). In Figure $8.2-1$, the sales prices per ton of product for the base case is correlated with the return on investment after taxes. The sales price is not very sensitive of the return-on-investment; for example, the sales price decreases about $\$ 0.70$ per ton ( $\$ 0.77$ per metric ton) for a $5 \%$ reduction in returnon-investment.

Similarly, the sales price is not strongly affected by the carbon dioxide loss or capital odst. From figure 8.2-2, a decrease in capital cost of $\$ 10 M$ reduces the sales price by less than $\$ 1.00$ per ton $(\$ 1.11$ per metric ton). A doubling of the carbon dioxide 1oss from $1 \%$ to $2 \%$ per ton of product increases the sales price by only $\$ 0.70$ per ton ( $\$ 0.77$ per metric ton) on product.

The sales price, hiciwever, is very sensitive to the plant capacity factor, as illustrated in figure 8.2-3. A decrease in plant utilization from 0.8 to 0.7 results in about $\$ 1.50$ per ton ( $\$ 1.65$ per metric ton) rise in sales price. The sensitivity to this parameter results from the large capital cost of the LICADO plant.

The estimated sales price for the LICADO process indicates that the process is in the same range as most of the deep cleaning processes based on price per ton of product. However, when prices are compared on the 


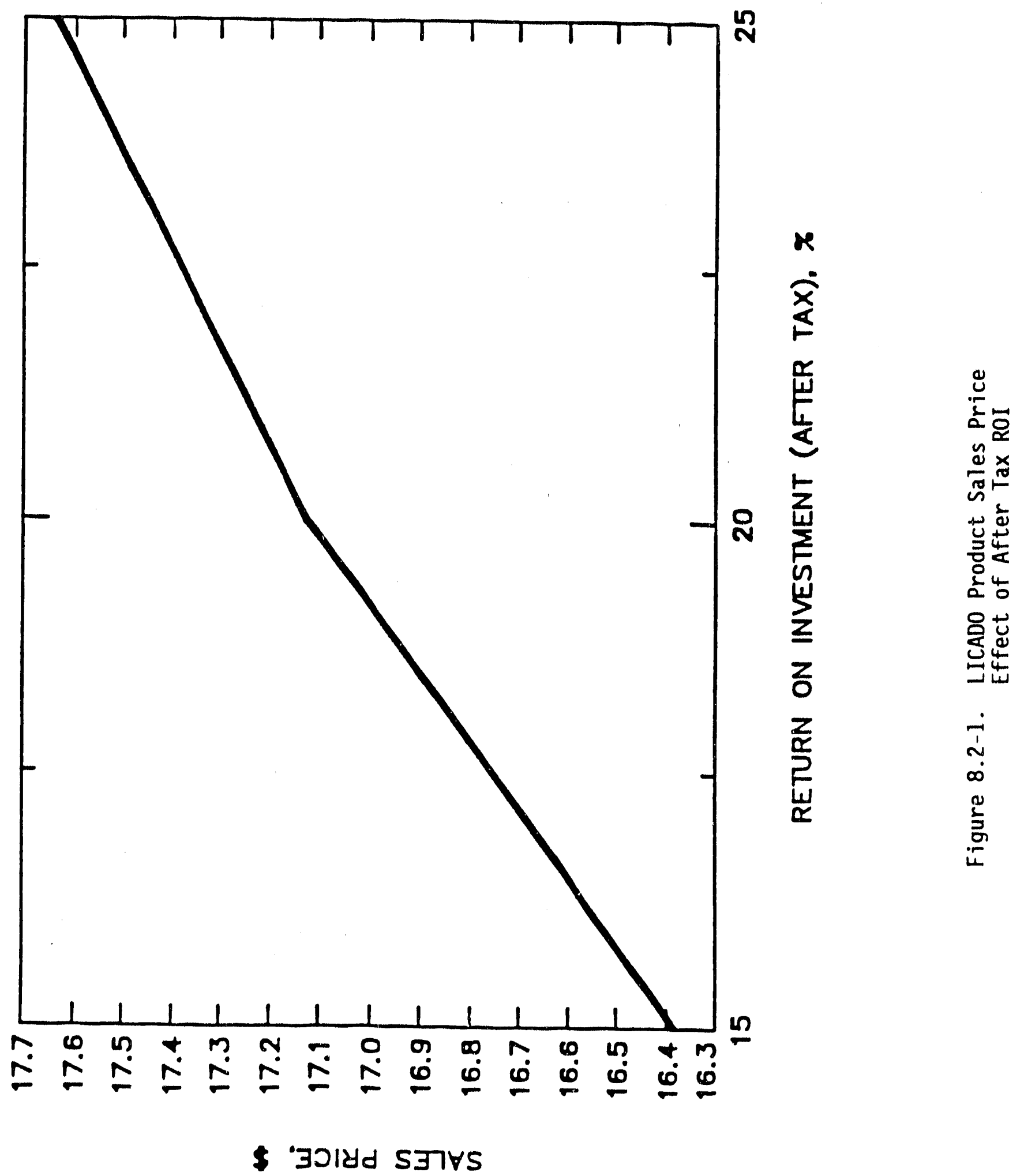




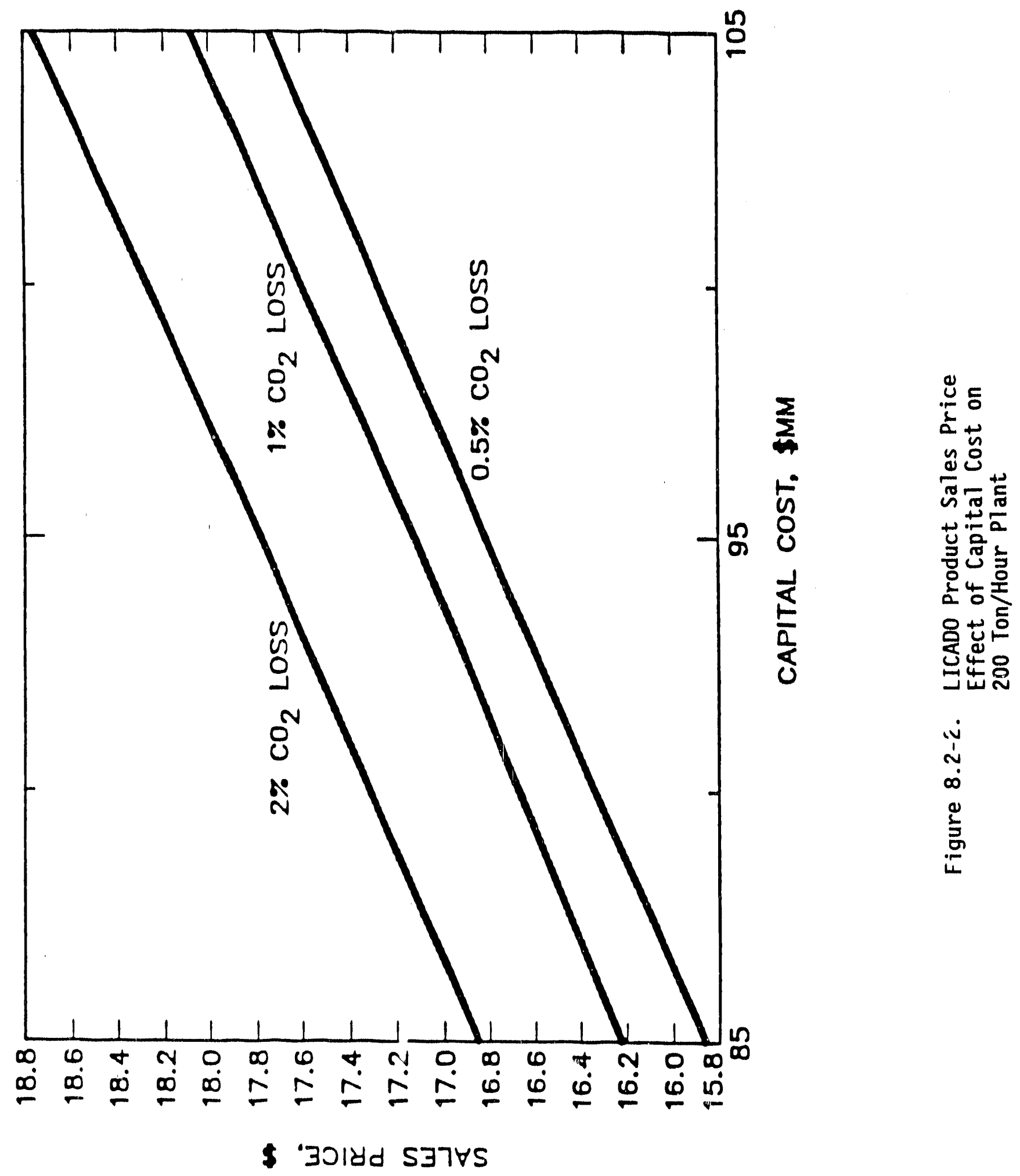




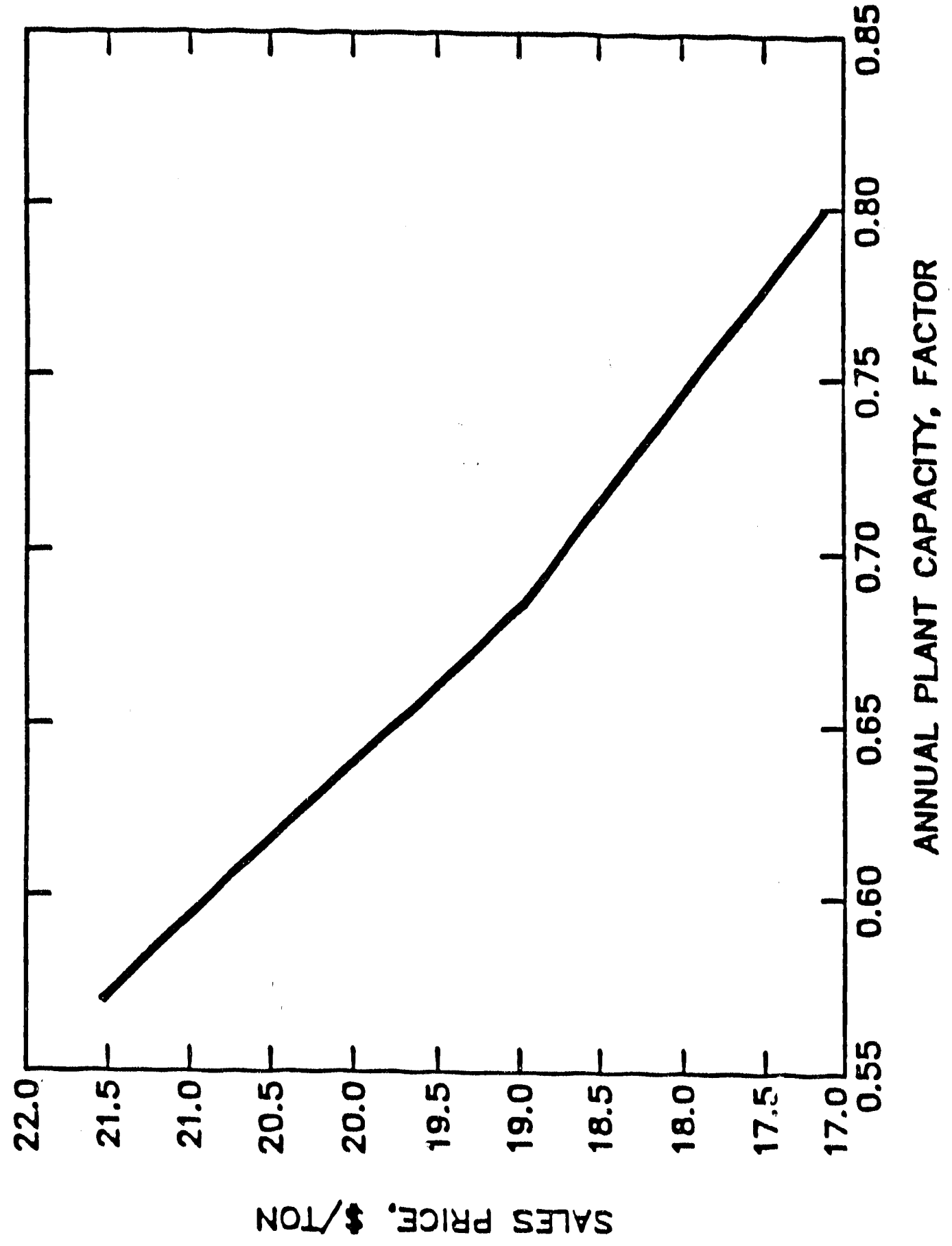

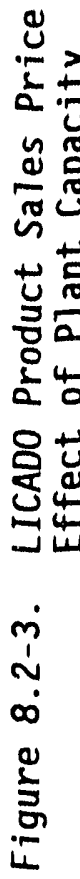


basis of heating value, the LICADO process will be 15 to $20 \% 1$ ess because of the 10w (10\% to $15 \%$ ) molsture resulting from this process, compared to the high moisture conterits of other physical cleaning processes $(25 \%$ to $30 \%$ moisture).

\subsubsection{Waste Recovery Plant}

Process economics were investigated for a 45 metric ton $/ \mathrm{hr}$ (50-ton per hour) plant that recovered fines from the waste stream of an exiting, conventional working $\mathrm{plant}$ or from a waste pond. For both of these applications, the plant is that described in Section 7.3. The capital cost of the plant is much lower than the ROM plant not only because of the difference in size by a factor of four, but because of plant equipment not required in the waste stream or waste pond application. For these applications, the grinding circuit and most of the waste processing systems are not required. The grinding circuit, which can be as much as one-third of the total plant capital cost, is not required in these applications, since the coal is already in the form of fine particles. Refuse concentrating and handling systems are ninimized in this design, since the wastes can be discharged directly into the waste pond for the existing plant or back into the waste pond, which is the source if pond waste is being processed.

The required processing sales price is $\$ 10.40$ per ton $(\$ 11.46$ per metric ton) for the 45 metric (50-ton) per $\mathrm{hr}$ plant operating to recover waste fines. The sales frice per ton of product is correlated with the plant capital costs, with a11 the other parameters at their reference case values, in figure 8.2-4. The sales price is not overly sensitive to the capital cost. For example, a change in capital cost of $\$ 2 M$ results in a change of only $\$ 0.80$ per ton ( $\$ 0.88$ per metric ton) of product.

The sensitivity of the product sales price to the cost of carbon dioxide $i$ : illustrated in Figure 8.2-5. Changes in carbon dioxide cost of $\pm 50 \%$ 


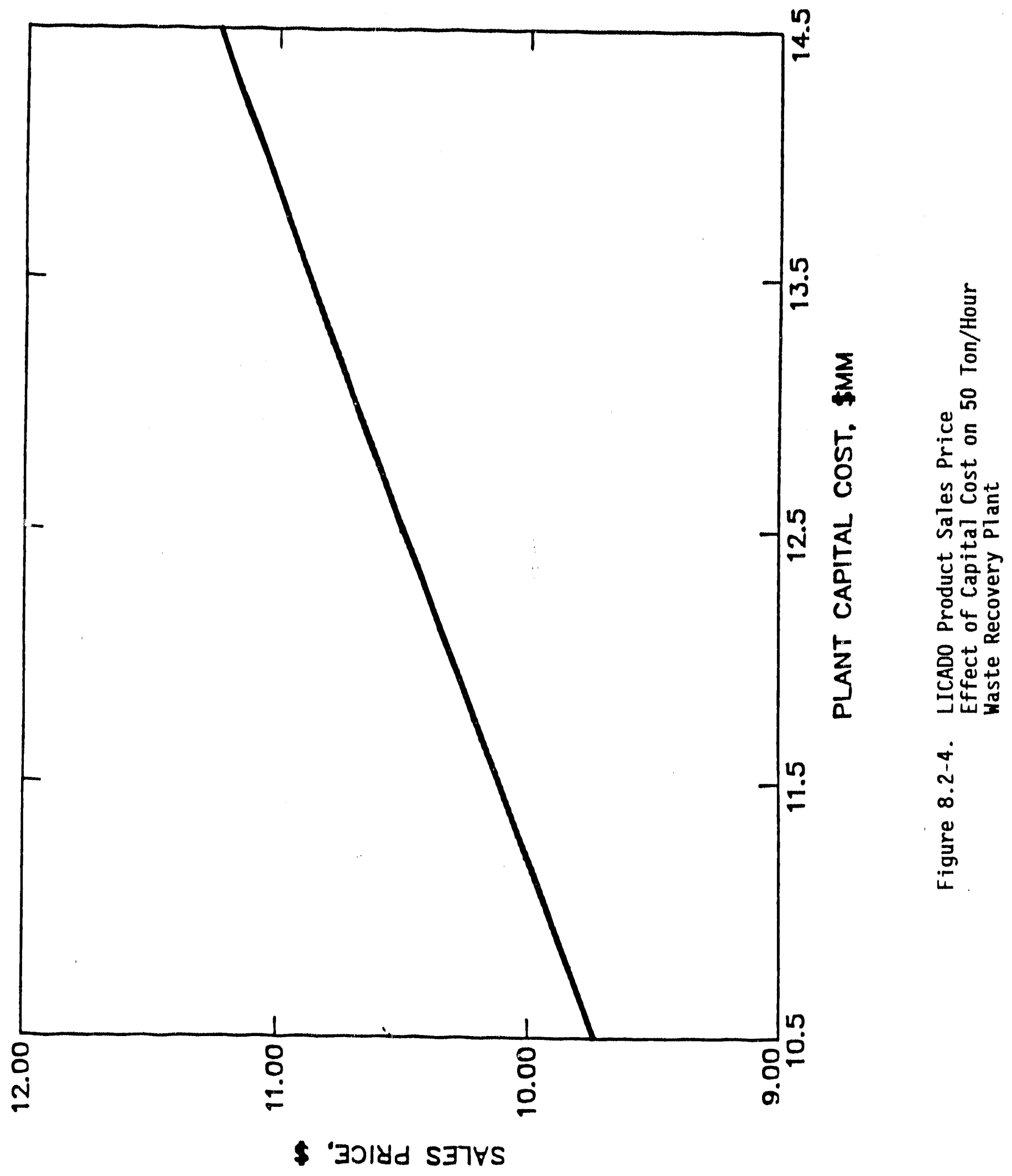




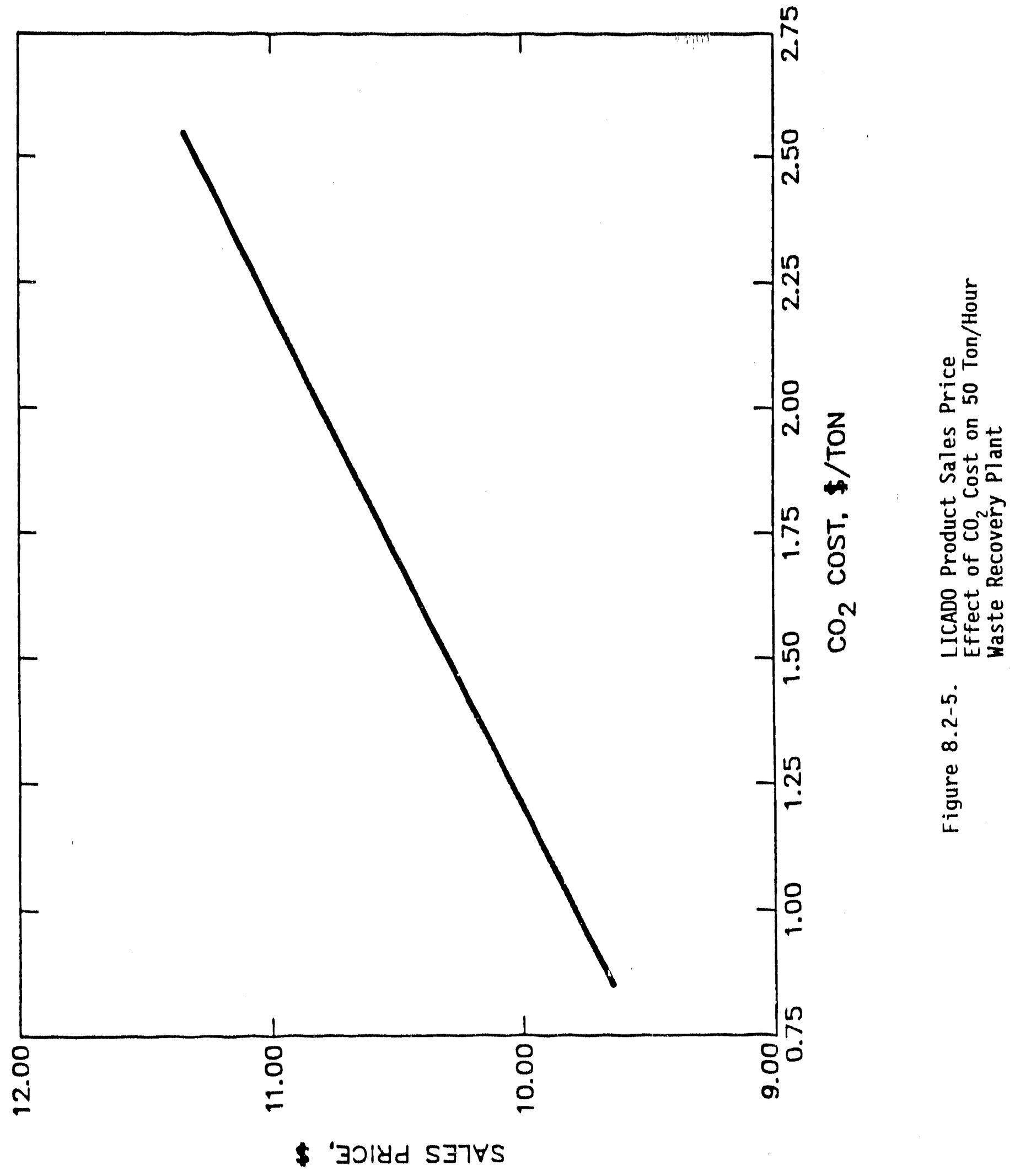


per ton of product result in about $\pm \$ 0.90$ per ton ( $\$ 0.99$ per metric ton) change in the sales price of the product. These costs are the result of the small amount of carbon dioxide that is absorbed on the product surface and the dissolved carbon dioxide in the waste water discharged with the refuse.

The sales price per ton of product is correlated with the plant capacity factor in Figure 8.2-6. In this case, the sales price is affected significantly by a decrease in plant capacity factor. A deciease of $25 \%$ in plant capacity (from 0.80 to 0.60 ) results in an increase in sales price of about $\$ 2.00$ per ton ( $\$ 2.20$ per metric ton).

This price per ton of recovered coal is very competitive, since a valuable product has been converted from waste materials. Compared to other processes that can recover and clean waste coals from the same sources, the LICADO process will have a 15-20\% advantage because of the lower water content of its product. 


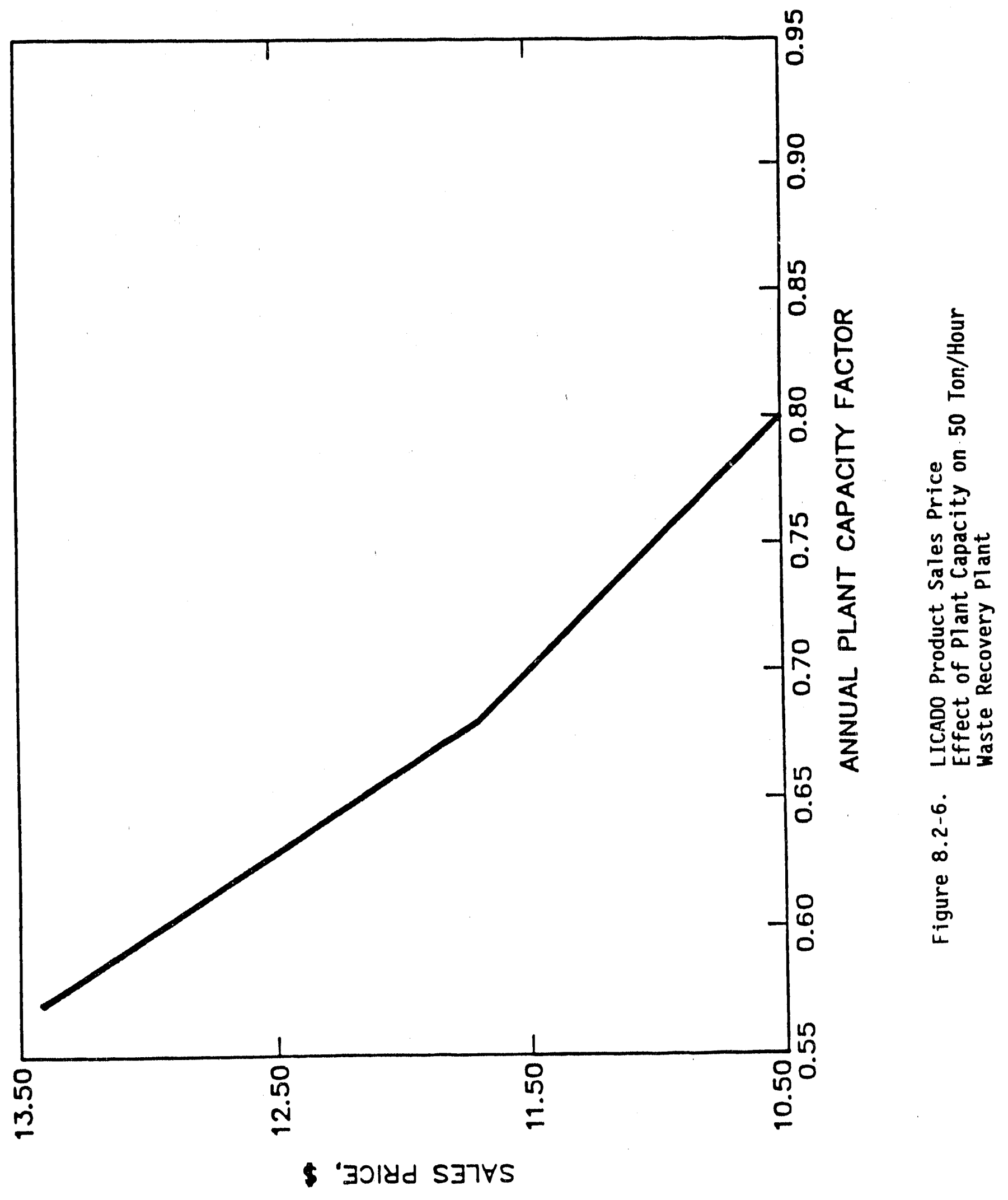




\subsection{SUMMARY, CONCLUSIONS, AND RECOMMENIDAIIONS}

In this section, the summary of this final repert is presented together with conclusions and recommendations.

\subsection{Summary}

The test program for this phase of the LICADO development program included batch tests using eight different coals: three Upper Freeport coals, two Pittsburgh seam coals, two Illinois No. 6 coals, and one Middle Kittanning coal. Initial tests were performed in a $5.1 \mathrm{~cm}(2$-inch) diameter column in the fixed volume mode of operation. In these tests, a fixed volume of coal-water slurry was mixed with a fixed volume of liquid $\mathrm{CO}_{2}$, and the two phases were separated and analyzed. Initial parametric tests demonstrated that a mixing speed of about $800 \mathrm{rpm}$ provided the best separation and recovery.

Twenty-seven experiments were performed for each of three coals using a factorial matrix to examine the effect of particle size, liquid $\mathrm{CO}_{2}$ flow rate, and slurry concentration upon process performance. The coals used in these experiments were Pittsburgh Bruceton, Middle Kittanning, and Illinois No. 6. Results of these tests showed:

- Finer particles increased heating value recovery.

- Higher slurry concentrations decreased heating value recovery and ash reduction for PittsburghBruceton coal, but not for the other coals.

- $\mathrm{CO}_{2}$ flowrate did not affect either the heating value recovery or ash reduction for any coal tested. 
More than 100 tests were made using variable liquid $\mathrm{CO}_{2}$ volume operation. In these tests, a fixed volume of coal-water slurry was contacted by flowing $\mathrm{CO}_{2}$. Clean coal was continuously removed from the top of the separator column. Thus, this variable volume (or semicontinuous operation) simulated the $\mathrm{CO}_{2}$ portion of the process, but the coal-water slurry became depleted of coal and enriched in mineral concentration as the coal particles were carried out by the flowing $\mathrm{CO}_{2}$. All eight of the coals were tested in the variable volume apparatus. Excellent results for these coals were obtained, with the best results of $95 \%$ ash and pyrite rejection being obtained with Upper Freeport coal. Results are very close to, and in some cases, better than the measured washability data for the same coal and particle size. The powdered coal product is relatively dry, containing 5 to $10 \%$ moisture. Use of 1-Octanol at $155 \mathrm{ppm}$ improved the process performance for Illinois No. 6 coal from $70 \%$ Btu recovery and $50 \%$ ash rejection to $80 \%$ for both Btu recovery and ash rejection. Use of sodium hexametaphosphate did not benefit the process.

Two-step (i.e., use of the product as the feed for a second cleaning) cleaning resulted in higher overall ash and pyrite rejection, but at lower overall yields. The reduced yield resulted from the additional losses of coal particles during the second cleaning step.

Tests of an integral two-stage separation system in the variable volume batch apparatus resulted in noticeable improvements in ash rejection and about the same Btu recovery as for a single-stage at low impeller speeds. At higher impeller speeds, the ash rejection remained relatively unchanged, whereas ash rejection was significantly reduced at higher speeds in the single-stage system.

The Continuous Research Unit, which simulates an integrated LICADO process with continuous coal-water slurry feed, liquid $\mathrm{CO}_{2}$ injection, product withdrawal and separation, and waste water withdrawal, has been successfully operater for periods as long as fourteen hours. Coal feed 
rates of 0.45 to $4.5 \mathrm{~kg} / \mathrm{hr}$ ( 1 to $10-1 \mathrm{~b} / \mathrm{hr}$ ) have been tested. The heating value recovery increases when the feed rate increases from $0.45 \mathrm{~kg} / \mathrm{hr}$ (1 $1 \mathrm{~b} / \mathrm{hr}$ ) to $1.35 \mathrm{~kg} / \mathrm{hr}(3 \mathrm{lb} / \mathrm{hr})$, but the heating value recovery decreases at feed rates greater than $2.70 \mathrm{~kg} / \mathrm{hr}(6-1 \mathrm{~b} / \mathrm{hr})$. This decrease at 2.72 $\mathrm{kg} / \mathrm{hr},(6-1 \mathrm{~b} / \mathrm{hr})$ is "caused by the limit of the $\mathrm{CO}_{2}$ flow rate through the column. This limit results from excessive coal carry-over from the coal product $/ \mathrm{CO}_{2}$ separator and is not a process limit. At 1.35 $\mathrm{kg} / \mathrm{hr}(3-1 \mathrm{~b} / \mathrm{hr})$ feed rate, heating value recoveries of $80 \%$, ash reductions of $75 \%$, and pyrite reductions of $80 \%$, are achieved with a product that is relatively dry. These results indicate that the overall performance of the continuous system approaches the limit of washability for the particle size (-200 mesh) tested.

A LICADO Simulation Model has been developed for use with a personal computer which provides material balances for each of the unit operations. The model, which is programmed in FORTRAN IV, uses input data characterizing the feed coal and required production and process data such as slurry concentration, $\mathrm{CO}_{2}$ flow rates, and separator/mixer residence times determined from the experimental program. In addition to material balances at each process unit, the program sizes the mixer and separator, including wall thicknesses, in compliance with the ASME Pressure Vessel Code. Piping sizes are also calculated.

Three conceptual plant designs have been developed, a 0.9 metric ton/hr (1 ton/hr) Proof-of-Concept Plant, a 181 metric ton $/ \mathrm{hr}$ (200 ton $/ \mathrm{hr}$ ) commercial plant, and a $45 \mathrm{metric}$ ton $/ \mathrm{hr}(50 \mathrm{ton} / \mathrm{hr}$ ) fines recovery $\mathrm{plant}$. The 0.9 metric ton/hr Proof-of-Concept Plant conceptual design was developed in the most detail, including plant arrangement drawings, equipment layouts for the grinding system, mixer, separator, and filter, and control system instrumentation functions and schematic. A detailed cost estimate was prepared for the Proof-of-Concept Plant, since final design and construction of this plant is the next logical step in developing the LICADO technology. The 181 metric ton/hr and 45 metric ton/hr plant 
designs were more conceptual and were used to provide budgetary capital and operating costs for use in economic studies of the process.

Economic studies have been made for a 181 metric ton $/ \mathrm{hr}$, stand-alone $\mathrm{plant}$ using run-of-mine coal as feed, and a 45 metric ton/hr plant processing waste fines from the waste stream of a conventional washing plant. The input parameters, other than capital and operating/maintenance cost, for the two studies were identical; i.e., $20 \%$ return on investment, $37 \%$ taxes, 20 -year plant 1 ife, $12 \%$ interest, $5 \%$ inflation rate, and $0.80 \mathrm{plant}$ capacity factor.

The required sales price for the LICADO process is $\$ 17.20 /$ ton for the 181 metric ton $/ \mathrm{hr}(200-$ ton $/ \mathrm{hr}) \mathrm{plant}$ and $\$ 10.40 /$ ton for the 45 metric ton $/ \mathrm{hr}$ (50-ton/hr) waste recovery plant. The sales price is not strongiy sensitive to plant capital cost or return-on-investiment, but is very sensitive to the plant capacity factor. These costs are competitive with other advanced physical coal cleaning processes, showing a $15-20 \%$ advantage on a cost per heating unit comparison because the lower moisture content of the LICADO process provides a higher heating va'ue.

\subsection{Conclusions}

The following conclusions result from the work described in this report:

- The LICADO process effectively reduces ash and pyrite from all the coals tested, with typical heating value recoveries in the 80 to $85 \%$ range, and ash/pyrite rejections of 80 to $90 \%$

- Results in both variable volume batch tests and continuous tests have achieved results close to or exceeding the washability data. This indicates that the process is limited by mirnmal liberation, and higher ash/pyrite rejections 
could be achieved with smaller particle sizes and multistage separation.

- Adequate ash/pyrite rejections at high Btu recoveries are achievable at a top size of -200 mesh. This particle size is more economical than finer sizes and is typical of the size used in pulverized coal boilers.

- Premixing the coal-water slurry with a portion of the $\mathrm{CO}_{2}$ enhances yield and slightly decreases ash/pyrite rejection compared to mixing all of the $\mathrm{CO}_{2}$ with the slurry in the Separation column. For example, the yield of 111 inois No. 6 increased about 12\%, while the pyrite rejection decreased 5\%, with an increase of premixing time from three to 10 minutes.

- Multistep variable volume batch operation improves ash/pyrite rejection at the expense of lower Btu recovery. Since the overall yields in this mode of operation are decreased, multistep operation is economically noncompetitive. For Middle Kittanning, coal, the ash reduction increased by almost $50 \%$ after the second step, with the loss of about $14 \%$ in yield.

- Multistage operation in the Batch Variable Volume operation showed noticeably improved separation, $(-13 \%)$ at equivalent heating value recoveries, and significantly less sensitivity to impeller speeds. 
- Multistage operation shows promise in improving the performance of the LICADO process in larger systems.

- Steady-state operation of the Continuous Research Unit has been demonstrated for up to fourteen hours. Continuous operation is 7 imited only by the supply of ground coal and the availability of the operators.

- The product is relatively dry (5 to $15 \%$ moisture) compared to other advanced physical cleaning processes (25 to $30 \%$ moisture). This eliminates the necessity of drying the coal product.

- Process costs, $\$ 17.40 /$ ton estimated for a standalone plant or $\$ 10.40 /$ ton for a waste recovery plant at an existing plant, are competitive with other advanced physical coal cleaning processes.

- On a cost per heating value basis, the LICADO processed coal will have a 15 to $20 \%$ cost advantage over processes with wet products because of its lower moisture content (lower moisture results in a higher heating value per pound and savings in drying cost).

\subsection{Recommendations}

The following recommendations result from the work performed in this phase of the LICADO development.

- Further experiments should be performed in the Continuous Research Unit at higher capacities, to 
$22.5 \mathrm{~kg} / \mathrm{hr}(50-1 \mathrm{~b} / \mathrm{hr})$, in the $15.2 \mathrm{~cm}(6-$ inch $)$ diameter separator.

- The multistage separator with several $\mathrm{CO}_{2}$ injections and mixing sections followed by agglomerating sections should be tested in the Continuous Research Unit.

- Performance assessments of the process in cleaning coal fines from several waste storage ponds should be made. Waste ponds containing several different coals should be investigated.

- The auger filter should be developed for larger capacities.

- A 0.9 metric ton (1-ton/hr) Proof-of-Concept Plant for the LICADO project should be constructed and operated to confirm the data obtained with the smaller scale systems, and to provide the data base for scale-up to a commercial scale demonstration plant. 
APPENDIX A

WASHABILITY DATA 
The washability data for four of the eight coals is presented Tables $A-1$ through $A-4$.

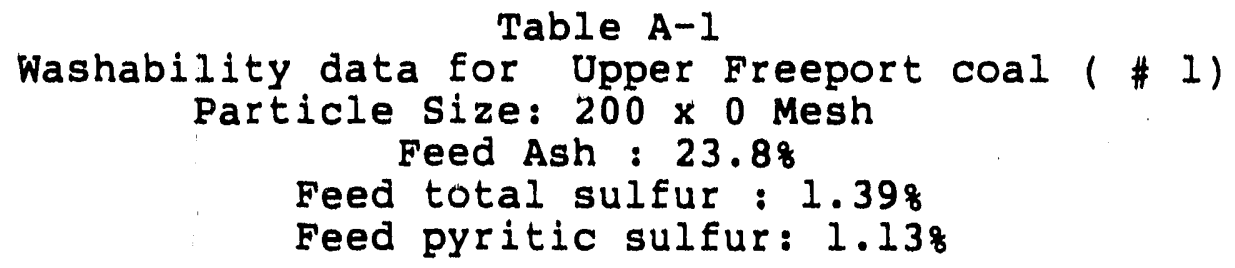

Specific Gravity

Specifle Gravity

Sink Float

$\begin{array}{llrlllll}- & 1.30 & 30.4 & 2.40 & 0.05 & 100.0 & 25.31 & 1.44 \\ 1.30 & 1.35 & 45.3 & 3.51 & 0.08 & 69.6 & 35.31 & 2.05 \\ 1.35 & 1.40 & 50.6 & 4.32 & 0.11 & 54.7 & 43.36 & 2.57 \\ 1.40 & 1.60 & 69.2 & 7.36 & 0.38 & 43.4 & 53.28 & 3.19 \\ 1.60 & 1.80 & 73.5 & 9.34 & 0.30 & 30.8 & 65.64 & 4.27 \\ 1.80 & - & 100.0 & 25.31 & 1.44 & 26.5 & 69.60 & 4.59\end{array}$

Cumulative Float Yield Ash Pyritic

(8)
(8) Sulfur

\section{Cumulative Sink \\ Yield Ash Pyritic \\ (z) \\ (8) \\ (8)}


Table A-2

Washability data for Middle Kittanning coal (\#6)

Particle Size: $200 \times 0$ Mesh

Feed Ash : 6.98

Feed total sulfur : $3.76 \%$

Feed pyritic sulfur: 3.328

Specific Gravity

-

Sink Float
Cumulative Float

Yield Ash Pyritic

(8)

(8)

Sulfur

( 8 )

Cumulative Sink

yield Ash pyritic

(8)

(8)

(z)

$\begin{array}{rrrrrrrr}- & 1.30 & 59.9 & 1.42 & 0.24 & 100.0 & 7.23 & 2.69 \\ 1.30 & 1.35 & 76.7 & 2.12 & 0.46 & 40.1 & 15.92 & 6.35 \\ 1.35 & 1.40 & 82.8 & 2.66 & 0.66 & 23.3 & 24.06 & 10.03 \\ 1.40 & 1.60 & 89.6 & 3.44 & 0.88 & 17.2 & 29.24 & 12.46 \\ 1.60 & 1.80 & 92.4 & 3.92 & 0.97 & 10.4 & 39.90 & 18.28 \\ 1.80 & - & 100.0 & 7.23 & 2.69 & 7.6 & 47.50 & 23.55\end{array}$




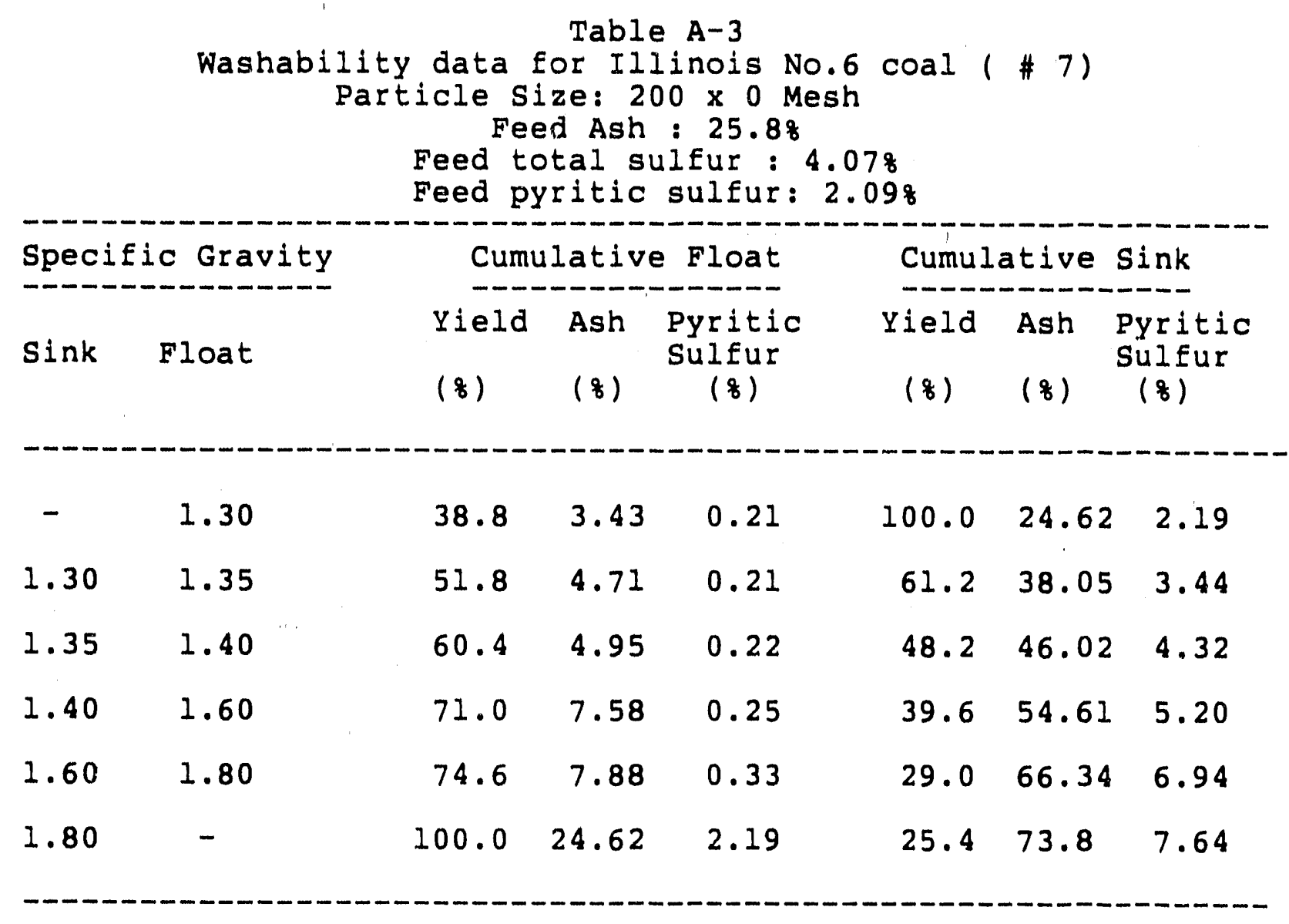


Table A-4

Washability data for Illinois No.6 coal (\#8)

Particle Size: $200 \times 0$ Mesh

Feed Ash : 13.58

Feed total sulfur : $2.20 \%$

Feed pyritic sulfur: 1.408

\begin{tabular}{|c|c|c|c|c|c|c|c|}
\hline \multicolumn{2}{|c|}{ Specific Gravity } & \multicolumn{3}{|c|}{ Cumulative Float } & \multicolumn{3}{|c|}{ Cumulative Sink } \\
\hline Sink & Float & $\begin{array}{l}\text { Yield } \\
(8)\end{array}$ & $\begin{array}{l}\text { Ash } \\
(z)\end{array}$ & $\begin{array}{l}\text { Pyritic } \\
\text { Sulfur } \\
\quad(8)\end{array}$ & $\begin{array}{l}\text { Yield } \\
(8)\end{array}$ & $\begin{array}{l}\text { Ash } \\
(8)\end{array}$ & $\begin{array}{l}\text { Pyritic } \\
\text { Sulfur } \\
(8)\end{array}$ \\
\hline - & 1.30 & 50.7 & 1.90 & 0.06 & 100.0 & 13.50 & 1.25 \\
\hline 1.30 & 1.35 & 53.5 & 1.90 & 0.06 & 49.3 & 25.4 & 2.77 \\
\hline 1.35 & 1.40 & 70.3 & 3.10 & 0.06 & 46.5 & 26.9 & 2.94 \\
\hline 1.40 & 1.60 & 85.1 & 4.90 & 0.06 & 29.7 & 38.1 & 4.57 \\
\hline 1.60 & 1.80 & 89.2 & 6.20 & 0.06 & 14.9 & 62.6 & 9.05 \\
\hline 1.80 & - & 100.0 & 13.50 & 1.25 & 10.8 & 73.8 & 12,46 \\
\hline
\end{tabular}




\section{DEFINITION OF DIAMETERS}

Volume-Surface Mean Diameter:

$$
D_{v s}=\frac{\sum_{i=1}^{n} N_{i} D_{i}^{3}}{\sum_{i=1}^{n} N_{i} D_{i}^{2}}
$$

Weight Mean Diameter:

$$
D_{w}=\frac{\sum_{i=1}^{n} N_{i} D_{i}^{4}}{\sum_{i=1}^{n} N_{i} D_{i}^{3}}
$$

Where $\mathrm{N}_{\mathrm{i}}$ = Number of particles

$D_{1}=$ Diameter of particles 
Volume-Surface Mean Diameter:

$$
D_{v s}=\frac{\sum_{i=1}^{n} N_{i} D_{i}^{3}}{\sum_{i=1}^{n} N_{1} D_{i}^{2}}
$$

Weight Mean Diameter:

$$
D_{w}=\frac{\sum_{i=1}^{n} N_{1} D_{i}^{4}}{\sum_{i=1}^{n} N_{1} D_{i}^{3}}
$$

$$
\text { Where } \begin{aligned}
N_{i} & =\text { Number of particles } \\
D_{1} & =\text { Diameter of particles }
\end{aligned}
$$


APDENDIX B

RESULTS FROM FIXED VOLUME BATCH TESTS 
A brief description of the methodology for statistical analysis is given below. This is followed by the presentation of the results for experiments conducted using the fixed volume batch unit.

The experiments in the fixed volume batch mode were designed at three levels and for three factors. These are indicated in Tables $B-1$ and $B-6$. The mąximum number of tests (without replication) in this case is $3^{3}=27$.

Two parameters were analyzed:

(a) Btu Recovery, defined as

$$
\text { Btu Recovery }(z)=\text { Yield } * \frac{(100-\text { Clean Coal Ash Content })}{(100-\text { Feed Coal Ash Content })}
$$

(b) Ash Reduction (AR), defined as

$$
\operatorname{AR}(8)=100-\frac{\text { Clean Coal Ash Content }}{\text { Feed Coal Ash Content }} \text { * } 100
$$

The data are analyzed for each factor as follows:

$$
\begin{aligned}
& \text { Total for each level: } t_{j}=\operatorname{sum}_{i=1}^{n} y_{i j} \quad j=1,2, \ldots, m \\
& n=\text { No. tests/level }=9 \\
& m=\text { No. levels }=3
\end{aligned}
$$

Total number of tests: $N=n \times m=27$

$$
\text { Sum of squares: } S S=\operatorname{suM}_{j=1} t_{j}^{2 / n}-s S_{t}
$$

$$
\text { n m }
$$


$\operatorname{ss}_{t}=\left(\operatorname{sum}_{i=1} \operatorname{sum}_{j=1} y_{i j}\right)^{2} / \mathbf{N}$

Total Sum of squares: SS $_{\text {TOT }}=\underset{i=1}{\operatorname{suM}} \underset{j=1}{\operatorname{mUM}} y_{i j}{ }^{2}-$ SS $_{t}$

Each factor has $f=m-1=2$ degrees of freedom and the total number of degrees of freedom is $\mathrm{f}_{\mathrm{TOT}}=\mathrm{N}-1=26$.

The mean square for each factor can be calculated as

$$
s^{2}=s s / f
$$

The residue is considered an estimation of the experimental error. The same parameters calculated for the factors can be determined for the residue:

$$
\begin{aligned}
& S S_{R}=S S_{T O T}-\underset{\text { factors }}{S U M S S} \\
& \left(s_{R}\right)^{2}=S S_{R} / f_{R} \\
& f_{R}=E_{T O T}-\underset{\text { factors }}{\text { SUM } F}=20 .
\end{aligned}
$$

The significance of each factor is determined by comparing the ratio $s /\left(s_{R}\right)$ with $F$ distribution values with $\left(E, f_{R}\right)$ degrees of freedom. In this case these values are:

\begin{tabular}{cc}
8 Confidence & $F(2,20)$ \\
\hline 75 & 1.49 \\
90 & 2.59 \\
95 & 3.49 \\
99 & 5.85 \\
\hline
\end{tabular}

The analysis of variance was performed for the Btu recovery and the ash reduction results of the fixed volume batch experiments. This was carried out for all three coals investigated ( i.e. coals designated as \#4, \#6 and \# 7 in Tables $3 \cdot 0-1)$. 
A summary of the analysis of variance results for Pittsburgh-Bruceton coal is given in Tables $B-1$ and $B-2$.

Table $B-.1$

Btu Recovery ( 8 ) Analysis of Variance Pittsburgh- Bruceton Coal

\begin{tabular}{|c|c|c|c|c|c|c|}
\hline FACTOR & $\begin{array}{l}\text { LEVEL } \\
\qquad 1\end{array}$ & $\begin{array}{l}A V \\
2\end{array}$ & $\begin{array}{c}\text { RAGE } \\
3\end{array}$ & SS & $s^{2}$ & $2 / s_{R}{ }^{2}$ \\
\hline PARTICLE SIZE & 71 & 77 & 74 & 208 & 104 & 1.95 \\
\hline SLURRY CONCENTRATION & 77 & 81 & 68 & 865 & 433 & 8.12 \\
\hline LIQUID $\mathrm{CO}_{2}$ FLOWRATE & 74 & 76 & 76 & 13 & 6 & 0.12 \\
\hline & \multicolumn{3}{|c|}{ Residue } & 1066 & 53 & \\
\hline
\end{tabular}

Table B-l demonstrates that slurry concentration is the only factor that significantly affects the Btu recovery of PittsburghBruceton coal. This is especially significant at a slurry concentration of 58 when higher Btu recoveries were obtained. The effect of particle size does not play a dominant role, possibly due to the small variation in particle size investigated.

Table B-2

Ash Reduction ( 8 ) Analysis of Variance Pittsburgh-Bruceton Coal

\begin{tabular}{|c|c|c|c|c|c|c|}
\hline FACTOR & $\begin{array}{l}\text { LEVEL } \\
I\end{array}$ & $\begin{array}{l}A V \\
2\end{array}$ & $\begin{array}{c}\text { RAGE } \\
3\end{array}$ & SS & $s^{2}$ & $s^{2} / s_{R}$ \\
\hline PARTICLE SIZE & 29 & 30 & 32 & 65 & 33 & 1.34 \\
\hline SLURRY CONCENTRATION & 34 & 30 & 28 & 164 & 82 & 3.38 \\
\hline LIQUID $\mathrm{CO}_{2}$ FLOWRATE & 33 & 30 & 29 & 80 & 40 & 1.64 \\
\hline
\end{tabular}

Table B-2 shows that none of the three factors exert a significant influence on the ash reduction characteristics of Pittsburgh-Bruceton coal. There is a marginal effect of slurry concentration at the lower value of $2.5 \%$ where the ash reduction appears to be higher. 
Table B-3

Btu Recovery ( 8 ) Analysis of Variance

Middle Kittanning Coal

\begin{tabular}{|c|c|c|c|c|c|c|}
\hline FACTOR & $\begin{array}{c}\text { LEVEL } \\
1\end{array}$ & $\begin{array}{l}\text { AV } 1 \\
2\end{array}$ & $\begin{array}{c}\text { RAGE } \\
3\end{array}$ & SS & $\mathrm{s}^{2}$ & $2 / s_{R}^{2}$ \\
\hline PARTICLE SIZE & 52 & 63 & 75 & 2274 & 1137 & 6.73 \\
\hline SLURRY CONCENTRATION & 57 & 68 & 64 & 574 & 287 & 1.70 \\
\hline LIQUID $\mathrm{CO}_{2}$ FLOWRATE & 63 & 67 & 60 & 186 & 93 & 0.55 \\
\hline & \multicolumn{3}{|c|}{ Residue } & 3380 & 169 & \\
\hline
\end{tabular}

Table B-3 shows the analysis of variance of the Btu recovery results. The analysis of variance indicates that the Btu recovery results are influenced significantly only by the particle size. This conclusion is significant at a 998 confidence level. These results show a clear trend suggesting that smaller particle size samples generate higher yields.

Table $B-4$

Ash Feduction (8) Analysis of Variance Middle Kittanning Coal

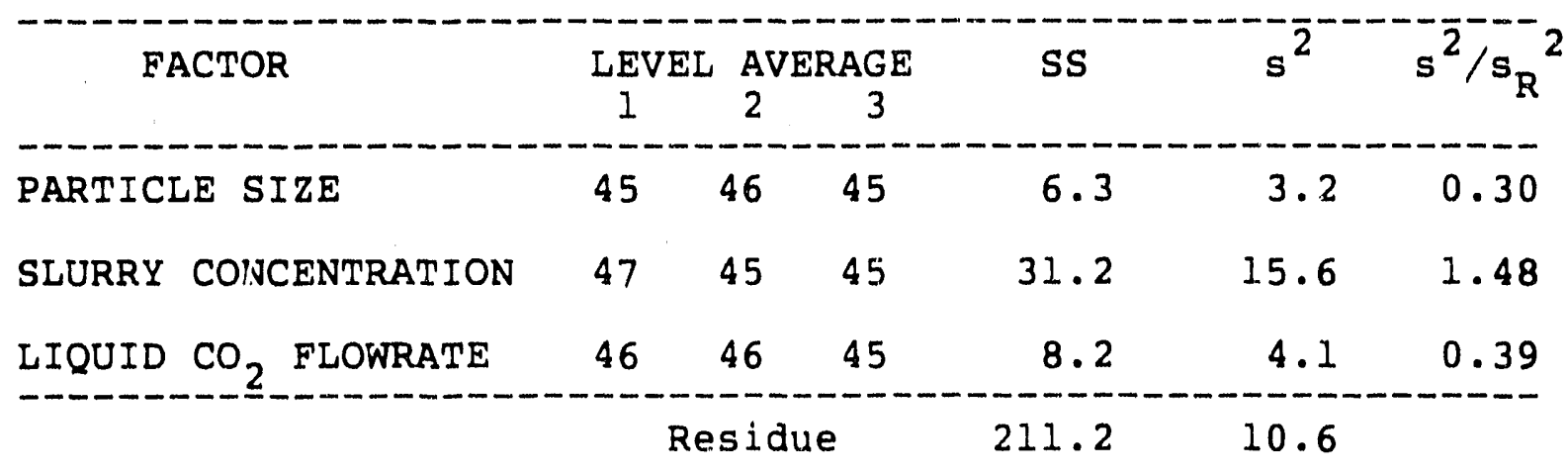

Table B-4 depicts the analysis of variance performed to the ash reduction results. The analysis indicates that none of the studied variables exert a significant effect on the ash reduction results.

A summary of the analysis of variance results for Illinois No.6 coal (26.08 ash sample) is given in Tables $B-5$ and $B-6$. 
Table B-5

Btu Recovery ( 8 ) Analysis of Variance

Illinois No. 6 Coal

\begin{tabular}{|c|c|c|c|c|c|c|}
\hline FACTOR & $\begin{array}{c}\text { LEVEL } \\
1\end{array}$ & $\begin{array}{l}\mathrm{AV} \\
2\end{array}$ & $\begin{array}{c}\text { RAGE } \\
3\end{array}$ & ss & $s^{2}$ & $\mathrm{~s}^{2} / \mathrm{s}_{\mathrm{R}}$ \\
\hline PARTICLE SIZE & 52 & 54 & 68 & 1359 & 680 & 9.51 \\
\hline SLURRY CONCENTRATION & 58 & 58 & 59 & 6 & 3 & 0.04 \\
\hline LIQUID $\mathrm{CO}_{2}$ FLOWRATE & 57 & 57 & 60 & 54 & 27 & 0.37 \\
\hline & \multicolumn{3}{|c|}{ Residue } & 1430 & 72 & \\
\hline
\end{tabular}

Table B-5 shows the analysis of variance of the Btu recovery results. The analysis of variance indicates that the Btu recovery results are influenced significantly only by the particle size. This conclusion is significant at a 99.98 confidence level. The Btu recovery results show a clear trend suggesting that smaller particle size samples generate better results. This is similar to the conclusion drawn for Middle Kittanning coal.

Table B-6

Ash Reduction (8) Analysis of Variance

Illinois No. 6 Coal

\begin{tabular}{|c|c|c|c|c|c|c|}
\hline FACTOR & $\begin{array}{c}\text { LEVEL } \\
I\end{array}$ & $\begin{array}{l}A V \\
2\end{array}$ & $\begin{array}{c}\text { RAGE } \\
3\end{array}$ & SS & $s^{2}$ & ${ }^{2} / s_{R}^{2}$ \\
\hline PARTICLE SIZE & 48 & 50 & 53 & 109.5 & 54.8 & 2.28 \\
\hline SLURRY CONCENTRATION & 49 & 51 & 52 & 48.3 & 24.2 & 1.01 \\
\hline LIQUID $\mathrm{CO}_{2}$ FLOWRATE & 48 & 51 & 51 & 52.4 & 26.2 & 1.09 \\
\hline & & & & 479.7 & 24.0 & \\
\hline
\end{tabular}

Table B-6 depicts the analysis of variance performed to the ash reduction results on the high ash Illinois No.6 coal. No significant effect can be observed for the slurry concentration and the liquid $\mathrm{CO}_{2}$ flowrate. There is a small effect of particle size on the ash reduction.

The raw data for the test results of 27 experiments with each of the three coals discussed above are presented in Tables B-7, B-8 and B-9. 
Table $B-7$

Pittsburgh-Bruceton coal (\#4)

Fixed volume batch tests

Impeller Speed: $1000 \mathrm{rpm}$.

\begin{tabular}{|c|c|c|c|c|c|c|}
\hline $\begin{array}{c}\text { Test } \\
\text { No. }\end{array}$ & $\begin{array}{l}\text { Particle } \\
\text { Size, } \\
\text { micróns }\end{array}$ & $\begin{array}{l}\text { Slurry } \\
\text { Conc. } \\
\text { wt. } 8\end{array}$ & $\begin{array}{l}\text { Liquid } \mathrm{CO} 2 \\
\text { Flowrate, } \\
\mathrm{ml} / \mathrm{min}\end{array}$ & $\begin{array}{c}\text { Ash } \\
\text { Reduction } \\
q\end{array}$ & $\begin{array}{c}\text { Btu } \\
\text { Recovery } \\
\text { \& }\end{array}$ & $\begin{array}{c}\text { Pyritic } \\
\text { Sulfur } \\
\text { Reduction, }\end{array}$ \\
\hline $\begin{array}{r}1 \\
2 \\
3 \\
4 \\
5 \\
6 \\
7 \\
8 \\
9 \\
10 \\
11 \\
12 \\
13 \\
14 \\
15 \\
16 \\
17 \\
18 \\
19 \\
20 \\
21 \\
22 \\
23 \\
24 \\
25 \\
26 \\
27\end{array}$ & $\begin{array}{l}50 \\
40 \\
33 \\
40 \\
33 \\
33 \\
40 \\
33 \\
50 \\
33 \\
50 \\
50 \\
40 \\
50 \\
33 \\
33 \\
40 \\
40 \\
50 \\
50 \\
33 \\
50 \\
33 \\
40 \\
50 \\
40 \\
40\end{array}$ & $\begin{array}{r}2.5 \\
5.0 \\
10.0 \\
2.5 \\
5.0 \\
5.0 \\
10.0 \\
2.5 \\
10.0 \\
5.0 \\
5.0 \\
10.0 \\
5.0 \\
5.0 \\
2.5 \\
2.5 \\
2.5 \\
2.5 \\
2.5 \\
10.0 \\
10.0 \\
5.0 \\
10.0 \\
5.0 \\
2.5 \\
10.0 \\
10.0\end{array}$ & $\begin{array}{r}100 \\
100 \\
25 \\
50 \\
100 \\
50 \\
100 \\
50 \\
25 \\
25 \\
100 \\
100 \\
25 \\
50 \\
25 \\
100 \\
25 \\
100 \\
25 \\
50 \\
50 \\
25 \\
100 \\
50 \\
50 \\
50 \\
25\end{array}$ & $\begin{array}{l}29 \\
33 \\
29 \\
35 \\
27 \\
31 \\
31 \\
35 \\
39 \\
29 \\
35 \\
24 \\
35 \\
29 \\
33 \\
39 \\
33 \\
29 \\
39 \\
35 \\
27 \\
31 \\
18 \\
22 \\
37 \\
18 \\
33\end{array}$ & $\begin{array}{l}87 \\
82 \\
76 \\
89 \\
88 \\
81 \\
67 \\
62 \\
73 \\
79 \\
82 \\
65 \\
71 \\
84 \\
69 \\
62 \\
80 \\
84 \\
75 \\
68 \\
61 \\
75 \\
64 \\
86 \\
86 \\
66 \\
69\end{array}$ & $\begin{array}{l}36 \\
44 \\
42 \\
38 \\
38 \\
33 \\
23 \\
30 \\
23 \\
26 \\
26 \\
20 \\
29 \\
24 \\
29 \\
32 \\
33 \\
21 \\
26 \\
27 \\
20 \\
26 \\
18 \\
29 \\
32 \\
24 \\
32\end{array}$ \\
\hline
\end{tabular}




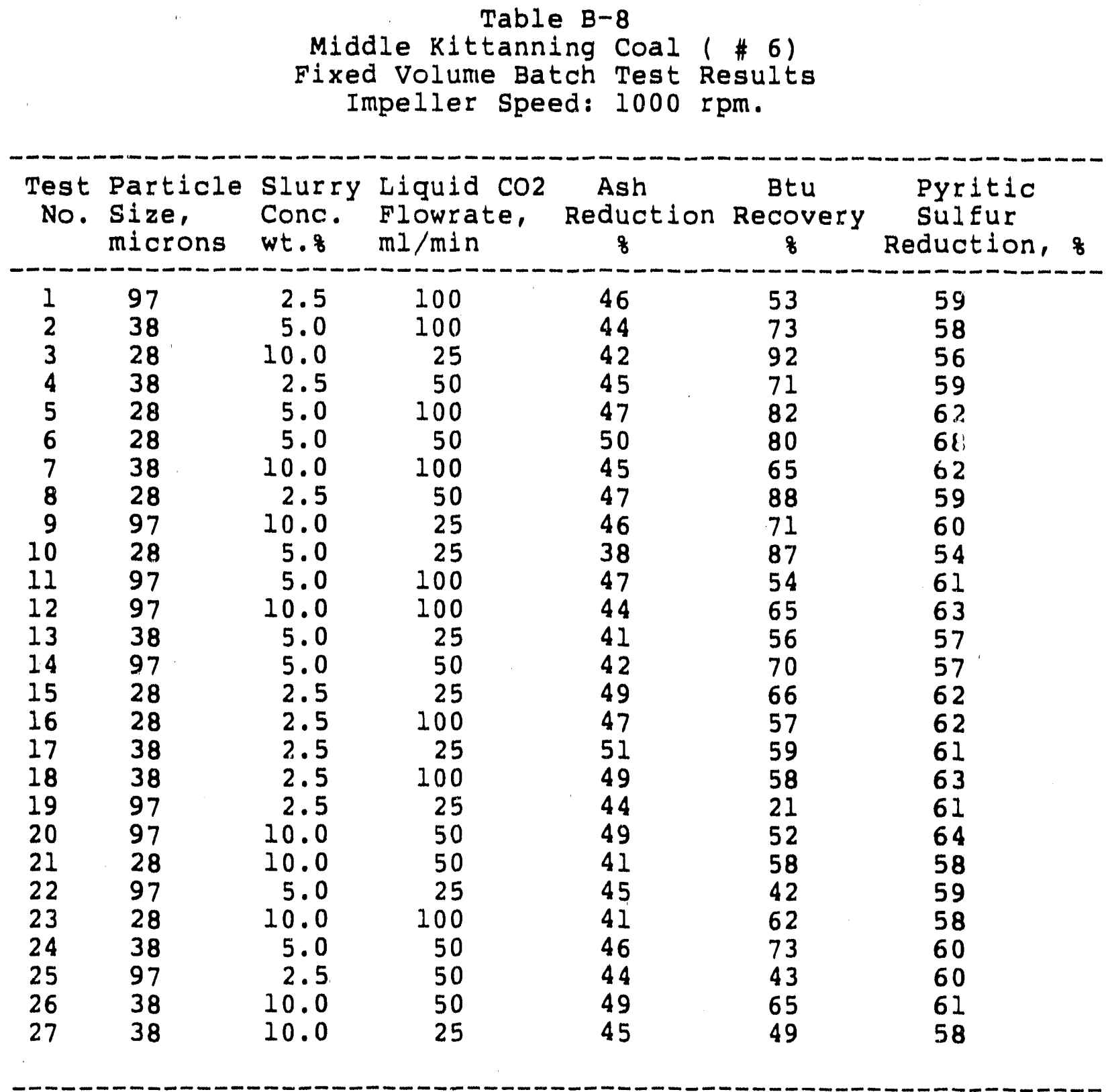


Table B-9

Illinoi.r No. 6 Coal (\#7)

Fixed Volume Batch Test Results

Impeller Speed: $1000 \mathrm{rpm}$.

\begin{tabular}{|c|c|c|c|c|c|c|}
\hline $\begin{array}{c}\text { Test } \\
\text { No. }\end{array}$ & $\begin{array}{l}\text { Particle } \\
\text { size, } \\
\text { microns }\end{array}$ & $\begin{array}{l}\text { Slurry } \\
\text { Cone. } \\
\text { wt. } 8\end{array}$ & $\begin{array}{l}\text { Liquid } \mathrm{CO} 2 \\
\text { Flowrate, } \\
\mathrm{ml} / \mathrm{min}\end{array}$ & $\begin{array}{c}\text { Ash } \\
\text { Reduction } \\
q\end{array}$ & $\begin{array}{c}\text { Btu } \\
\text { Recovery } \\
\delta\end{array}$ & $\begin{array}{c}\text { Pyritic } \\
\text { Sulfur } \\
\text { Reduction, }\end{array}$ \\
\hline $\begin{array}{l}1 \\
2 \\
3 \\
4 \\
5 \\
6 \\
7 \\
8 \\
9 \\
10 \\
11 \\
12 \\
13 \\
14 \\
15 \\
16 \\
17 \\
18 \\
19 \\
20 \\
21 \\
22 \\
23 \\
24 \\
25 \\
26 \\
27\end{array}$ & $\begin{array}{l}70 \\
50 \\
41 \\
50 \\
41 \\
41 \\
50 \\
41 \\
70 \\
41 \\
70 \\
70 \\
50 \\
70 \\
41 \\
41 \\
50 \\
50 \\
70 \\
70 \\
41 \\
70 \\
41 \\
50 \\
70 \\
50 \\
50\end{array}$ & $\begin{array}{r}2.5 \\
5.0 \\
10.0 \\
2.5 \\
5.0 \\
5.0 \\
10.0 \\
2.5 \\
10.0 \\
5.0 \\
5.0 \\
10.0 \\
5.0 \\
5.0 \\
2.5 \\
2.5 \\
2.5 \\
2.5 \\
2.5 \\
10.0 \\
10.0 \\
5.0 \\
10.0 \\
5.0 \\
2.5 \\
10.0 \\
10.0\end{array}$ & $\begin{array}{r}100 \\
100 \\
25 \\
50 \\
100 \\
50 \\
100 \\
50 \\
25 \\
25 \\
100 \\
100 \\
25 \\
50 \\
25 \\
100 \\
25 \\
100 \\
25 \\
50 \\
50 \\
25 \\
100 \\
50 \\
50 \\
50 \\
25\end{array}$ & $\begin{array}{l}42 \\
57 \\
56 \\
46 \\
58 \\
56 \\
44 \\
52 \\
55 \\
58 \\
37 \\
51 \\
45 \\
45 \\
47 \\
51 \\
51 \\
48 \\
49 \\
53 \\
52 \\
51 \\
48 \\
52 \\
51 \\
55 \\
51\end{array}$ & $\begin{array}{l}48 \\
56 \\
76 \\
47 \\
75 \\
55 \\
56 \\
60 \\
51 \\
80 \\
37 \\
55 \\
52 \\
45 \\
63 \\
71 \\
49 \\
53 \\
67 \\
53 \\
70 \\
52 \\
63 \\
70 \\
60 \\
52 \\
52\end{array}$ & $\begin{array}{l}33 \\
37 \\
31 \\
34 \\
33 \\
37 \\
32 \\
36 \\
34 \\
30 \\
30 \\
33 \\
32 \\
32 \\
32 \\
28 \\
33 \\
38 \\
34 \\
32 \\
32 \\
30 \\
31 \\
34 \\
34 \\
34 \\
31\end{array}$ \\
\hline
\end{tabular}


Table $B-10$

Particle size Distribution after $3 \mathrm{~min}$ grinding Middle Kittanning coal (\#6)

\begin{tabular}{|c|c|c|c|}
\hline $\begin{array}{c}\text { size } \\
\text { (microns) }\end{array}$ & $\begin{array}{c}\text { Particles } \\
\text { Over }\end{array}$ & $\begin{array}{l}\text { No } 8 \\
\text { Over }\end{array}$ & $\begin{array}{l}\text { Weight o } \\
\text { Over }\end{array}$ \\
\hline $\begin{array}{r}2.0 \\
4.0 \\
6.3 \\
10.0 \\
12.6 \\
15.8 \\
19.9 \\
25.1 \\
31.6 \\
39.8 \\
50.1 \\
63.1 \\
79.4 \\
100.0 \\
125.8 \\
158.4\end{array}$ & $\begin{array}{r}8042 \\
5007 \\
2682 \\
1259 \\
868 \\
622 \\
429 \\
305 \\
211 \\
147 \\
101 \\
60 \\
30 \\
15 \\
7 \\
0\end{array}$ & $\begin{array}{r}100.00 \\
62.26 \\
33.35 \\
15.66 \\
10.79 \\
7.73 \\
5.33 \\
2.79 \\
2.62 \\
1.83 \\
1.26 \\
0.75 \\
0.37 \\
0.19 \\
0.09 \\
0.00\end{array}$ & $\begin{array}{r}100.00 \\
99.89 \\
99.47 \\
98.44 \\
97.69 \\
96.74 \\
95.28 \\
93.39 \\
90.53 \\
86.64 \\
81.07 \\
71.14 \\
56.65 \\
42.1 .9 \\
26.82 \\
0.00\end{array}$ \\
\hline $\begin{array}{r}\text { Size } \\
\text { Rangye }\end{array}$ & $\begin{array}{l}\text { No } 8 \\
\text { Range }\end{array}$ & & 8 \\
\hline $\begin{array}{r}2.0-4.0 \\
4.0-6.3 \\
6.3-14.0 \\
10.0-12.6 \\
12.6-15.8 \\
15.8-19.9 \\
19.9-25.1 \\
25.1-31.6 \\
31.6-39.6 \\
39.8-50.1 \\
50.1-63 \\
63.1-79 \\
79.4-100.1 \\
100.0-125.8 \\
125.8-158.4\end{array}$ & $\begin{array}{l}37.73 \\
28.91 \\
17.69 \\
4.86 \\
3.05 \\
2.40 \\
1.54 \\
1.16 \\
0.79 \\
0.57 \\
0.51 \\
0.37 \\
0.18 \\
0.09 \\
0.08\end{array}$ & & \\
\hline
\end{tabular}

Length Diameter $=7.7$ microns

Surfare-Volume Diameter $=57.4 \mathrm{microns}$

Weight Diameter $=90.1$ microns 
Table B-11

Particle size Distribution after 3 min grinding Pittsburgh-Bruceton coal (\#4)

\begin{tabular}{|c|c|c|c|}
\hline $\begin{array}{c}\text { Size } \\
\text { (microns) }\end{array}$ & $\begin{array}{c}\text { Particles } \\
\text { Over }\end{array}$ & $\begin{array}{l}\text { No } 8 \\
\text { Over }\end{array}$ & $\begin{array}{l}\text { Weight } \\
\text { Over }\end{array}$ \\
\hline $\begin{array}{r}2.0 \\
4.0 \\
6.3 \\
10.0 \\
12.6 \\
15.8 \\
19.9 \\
25.1 \\
31.6 \\
39.8 \\
50.1 \\
63.1 \\
79.4 \\
100.0 \\
125.8 \\
158.4 \\
200.0 \\
316.1\end{array}$ & $\begin{array}{r}15202 \\
10326 \\
6250 \\
3145 \\
2161 \\
1493 \\
1009 \\
672 \\
434 \\
253 \\
135 \\
65 \\
40 \\
25 \\
18 \\
10 \\
4 \\
0\end{array}$ & $\begin{array}{r}100.00 \\
67.93 \\
41.11 \\
20.69 \\
14.22 \\
9.82 \\
6.64 \\
4.42 \\
2.85 \\
1.66 \\
0.89 \\
0.43 \\
0.26 \\
0.16 \\
0.12 \\
0.07 \\
0.03 \\
0.00\end{array}$ & $\begin{array}{r}100.00 \\
99.93 \\
99.65 \\
98.78 \\
98.05 \\
97.06 \\
95.64 \\
93.66 \\
90.87 \\
86.62 \\
81.10 \\
74.56 \\
69.90 \\
64.32 \\
59.13 \\
47.29 \\
29.50 \\
0.00\end{array}$ \\
\hline $\begin{array}{r}\text { Size } \\
\text { Range }\end{array}$ & $\begin{array}{l}\text { No } \& \\
\text { Range }\end{array}$ & & 8 \\
\hline $\begin{array}{r}2.0-4.0 \\
4.0-6.3 \\
6.3-10.0 \\
10.0-12.6 \\
12.6-15.8 \\
15.8-19.9 \\
19.9-25.1 \\
25.1-31.6 \\
31.6-39.8 \\
39.8-50.1 \\
50.1-63.1 \\
63.1-79.4 \\
79.4-100.0 \\
100.0-125.8 \\
125.8-158.4 \\
158.4-200.0 \\
200.0-316.6\end{array}$ & $\begin{array}{l}32.07 \\
26.81 \\
20.43 \\
6.47 \\
4.39 \\
3.18 \\
2.21 \\
1.56 \\
1.19 \\
0.77 \\
0.46 \\
0.16 \\
0.09 \\
0.04 \\
0.05 \\
0.04 \\
0.00\end{array}$ & & \\
\hline
\end{tabular}

Length Diameter $=8.4$ microns

Surface-Volume Diameter $=70.5$ microns

Weight Diameter $=145.8$ microns 
Tabie $B-12$.

Particle size Distribution after $3 \mathrm{~min}$ grinding Illinois No.6 coal (\#7)

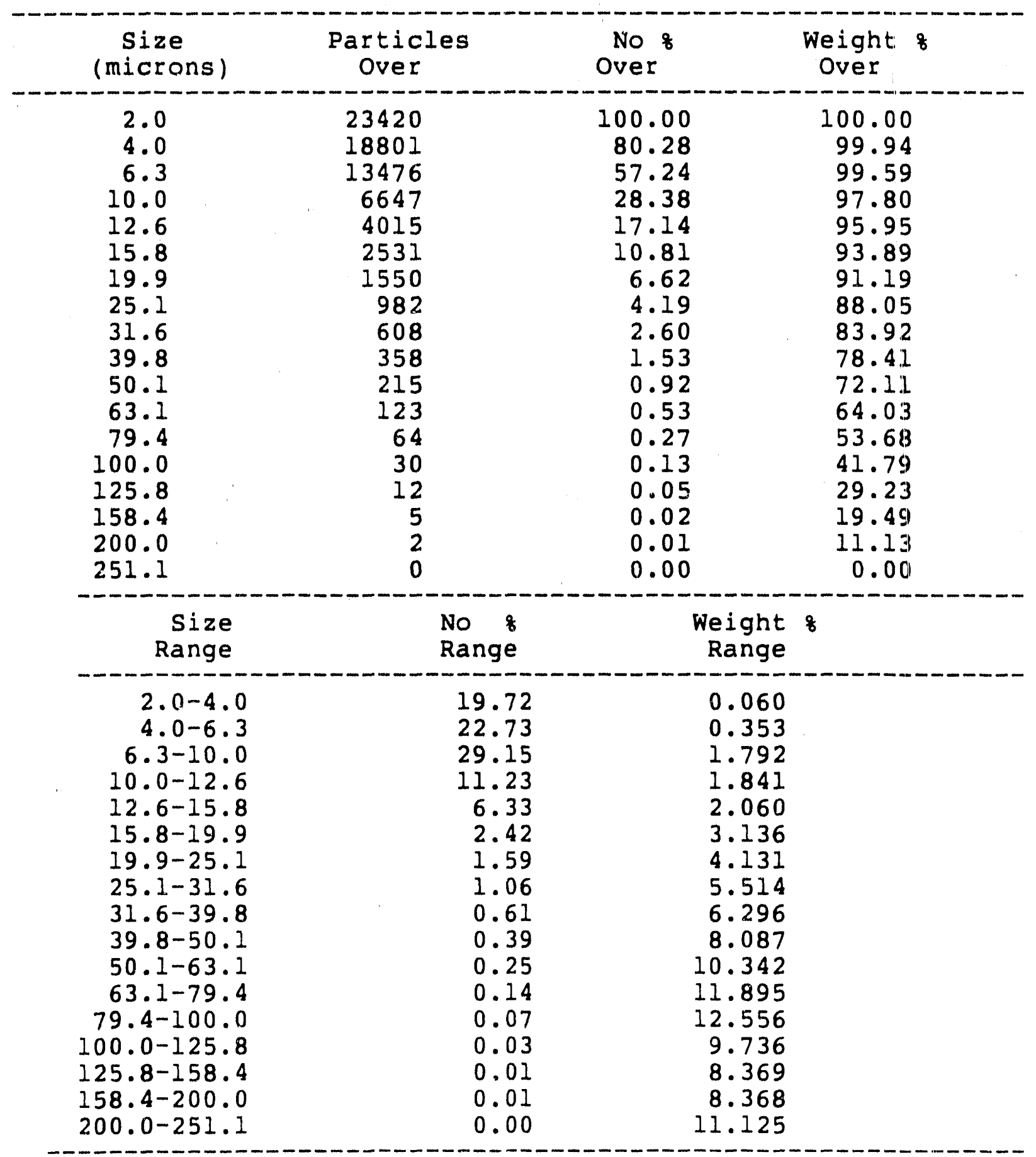

Length Diameter $=9.4$ microns

Surface-Volume Diameter $=48.9$ microns

Weight Diameter $=98.5$ microns 
APPENDIX C

RESULTS FROM VARIABLE VOLUME BATCH TESTS

$c-1$ 
*:k** Nomen: lature *****

1. Af---- Ain Content of Feed (\%)

2. Ap-- Ash Content of Product (\%)

3. Ar--- Ash Content of Refuse (\%)

4. ARD-- Asin Reduction ( $y$ )

$A R D=(1-A P / A f) \times 100 \%$

5. ARJ--- Ash Rejection (\%)

ARJ $=(1-Y \times A P /(100 \times$ Af $)) \times 100 \%$

6. BTUR--- BTU Recovery (\%)

BTUR $=Y \times[1-(\mathrm{Ap} / 100)] /[1-(\mathrm{Af} / 100)]$

7. CS --- Coal Seam

8. Co --.- Initial Slurry Concentration (\%)

9. Dp --- Particle Size (microng)

10. D -.- Diameter of Column (inches)

11. d --. Impeller Diameter (inches)

12. H -- Slurry Layer Height (inches)

13. Nprem --- Premiring Speed (rpm)

14. $\mathrm{N}$ - Impeller Speed in Operating Period (rpm)

15. P-- Operating Pressure (psi)

16. Q -..- Liquid CO2 Flow Rate (cc/min)

17. Sf--- Total Sulfur Content in Feed Coal (\%)

18. Sp -.. Total Sulfur Content in Product (\%)

19. Sr --- Total Suifur Content in Refuse (\%)

20. Spyrf -- Pyritic Sulfur Content in Feed Coal (\%)

21. Spyro --. Pyritic Sulfur Content in Product Coal (\%)

22. Spyrr --- Pyritic Sulfur Content in Refuge (\%)

23. Sorizn -- Organic Suifur Content (\%)

24. SRdpyr - - Pyritic Sulfur Reduction (\%)

25. SRipyr -- Prritic Sulfur Rejection (min)

SRdpyr $=1-($ Sp/Sf $)$

SRjpyr $=1-(Y \times$ Spyrp $/ 100 \pi$ Spyrf $)$

26. Tmix -- Premixing Time (min)

27. Tinj -- Liquid CO2 Injection Time (min)

28. Y -.- Orerall Yield (\%) 


\begin{tabular}{|c|c|c|c|c|c|c|c|c|c|c|c|c|c|}
\hline RUN & $\begin{array}{c}\text { Co } \\
x\end{array}$ & $\begin{array}{l}\text { Af } \\
x\end{array}$ & $\begin{array}{c}\text { Spyr } \\
x\end{array}$ & $\begin{array}{c}\text { Nprem } \\
\text { rpm }\end{array}$ & $\begin{array}{r}\operatorname{Tmix} \\
\min \end{array}$ & $\begin{array}{c}N \\
r p m\end{array}$ & $\stackrel{0}{c c / m i n}$ & $\begin{array}{l}A p \\
x\end{array}$ & $\begin{array}{l}\text { Ar } \\
x\end{array}$ & $\begin{array}{l}y \\
X\end{array}$ & $\begin{array}{c}\text { BTUR } \\
x\end{array}$ & $\begin{array}{c}\text { ARD } \\
x\end{array}$ & $\underset{x}{A R J}$ \\
\hline \multicolumn{14}{|c|}{ 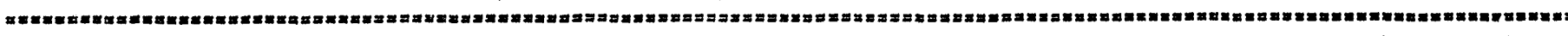 } \\
\hline UP1 & 7.5 & 24.4 & 1.14 & 1320 & 5.0 & 1320 & 400 & 6.6 & 50.0 & 59.0 & 72.9 & 73.0 & 84.0 \\
\hline UPZ & 7.5 & 24.4 & 1.14 & 1320 & 5.0 & 1320 & 400 & 8.8 & 50.9 & 62.9 & $\pi .9$ & 63.9 & 77.3 \\
\hline UP3 & 7.5 & 24.4 & 1.14 & 1320 & 5.0 & 1320 & 400 & 4.4 & 67.5 & 68.3 & 86.4 & 82.0 & 87.7 \\
\hline UP4 & 7.5 & 24.4 & 1.14 & 1320 & 5.0 & 1700 & 400 & 11.9 & 60.8 & 74.4 & 86.7 & 51.2 & 63.7 \\
\hline UP8 & 6.4 & 24.4 & 1.14 & $\$ 320$ & 5.0 & 600 & 400 & 2.1 & 49.9 & 53.3 & 69.1 & 91.4 & 95.4 \\
\hline UP6 & 6.4 & 24.4 & 1.14 & 1320 & 5.0 & 1000 & 400 & 3.9 & 62.2 & 64.8 & 82.4 & 84.0 & 89.6 \\
\hline UP7 & 6.4 & 24.4 & 1.14 & 1320 & 5.0 & 1320 & 400 & 4.5 & 67.8 & 68.6 & 86.6 & 81.6 & 87.4 \\
\hline UP 10 & 6.4 & 24.4 & 1.14 & 1320 & 5.0 & 1700 & 400 & 9.5 & 66.8 & 74.0 & 88.6 & 61.1 & 71.2 \\
\hline UP11 & 6.4 & 24.4 & 1.14 & 1320 & 5.0 & 1000 & 550 & 4.0 & 63.7 & 65.8 & 83.6 & 83.6 & 89.2 \\
\hline UP12 & 6.4 & 24.4 & 1.14 & 1320 & 5.0 & 1000 & 750 & 4.1 & 66.6 & 67.5 & 85.7 & 83.2 & 88.7 \\
\hline UP13 & 6.4 & 24.4 & 1.14 & 1320 & 5.0 & 1000 & 1000 & 5.7 & 67.1 & 69.5 & 86.7 & 76.6 & 83.8 \\
\hline UP64 & 6.4 & 22.7 & 1.14 & 0 & 0 & 1000 & 400 & 3.2 & 58.7 & 64.9 & 81.2 & 85.9 & 90.9 \\
\hline UP65 & 6.4 & 22.7 & 1.14 & 0 & 0 & 1000 & 400 & 3.4 & 55.2 & 62.7 & 78.4 & 85.0 & 90.6 \\
\hline UP63 & 7.5 & 24.4 & 1.14 & 2500 & 0.5 & 1000 & 400 & 2.7 & 55.7 & 59.1 & 76.0 & 88.9 & 93.5 \\
\hline UP46 & 6.4 & 24.4 & 1.14 & 2050 & 10.0 & 1000 & 400 & 5.9 & 59.8 & 65.7 & 81.7 & 75.8 & 84.1 \\
\hline UP36 & 4.7 & 24.4 & 1.14 & 1680 & 7.0 & 1000 & 400 & 4.5 & 58.2 & 62.9 & 79.5 & 81.6 & 88.4 \\
\hline UP39 & 4.7 & 22.7 & 1.14 & 1680 & 7.0 & 1006 & 400 & 4.8 & 57.1 & 65.8 & 81.0 & 78.9 & 86.1 \\
\hline UPG8 & 4.7 & 24.4 & 1.14 & 1680 & 7.0 & 1000 & 400 & 4.3 & 62.0 & 65.2 & 82.5 & 82.4 & 88.5 \\
\hline UP69 & 4.7 & 26.6 & 1.14 & 1680 & 7.0 & 1000 & 400 & 22.4 & 37.9 & 72.9 & 77.1 & 15.8 & 38.6 \\
\hline UP7O & 4.7 & 24.4 & 1.14 & 1680 & 7.0 & 1000 & 400 & 4.5 & 59.6 & 63.9 & 80.7 & 81.6 & 88.2 \\
\hline UP71 & 4.7 & 24.4 & 1.14 & 1680 & 7.0 & 1000 & 400 & 4.1 & 65.3 & 66.8 & 84.8 & 83.2 & 88.8 \\
\hline UP49 & 6.4 & 22.7 & 1.14 & 2050 & 10.0 & 800 & 400 & 4.9 & 56.9 & 65.8 & 80.9 & 78.4 & 85.8 \\
\hline UP56 & 6.4 & 22.7 & 1.14 & 2050 & 10.0 & 1000 & 400 & 4.9 & 58.7 & 66.9 & 82.3 & 78.4 & 85.6 \\
\hline UP6O & 6.4 & 23.4 & 1.14 & 2050 & 10.0 & 1500 & 400 & 7.3 & 60.5 & 69.7 & 84.4 & 68.8 & 78.2 \\
\hline UP59 & 6.4 & 23.4 & 1.14 & 2050 & 10.0 & 2050 & 400 & 13.2 & 65.0 & 80.3 & 91.0 & 43.6 & 54.7 \\
\hline UPBI & 4.7 & 23.4 & 1.14 & 2050 & 7.0 & 1000 & 500 & 3.9 & 53.4 & 60.6 & 76.0 & 83.3 & 89.9 \\
\hline UP8O & 4.7 & 23.4 & 1.14 & 2050 & 7.0 & 1320 & 500 & 5.9 & 53.3 & 63.1 & 7.5 & 74.8 & 84.1 \\
\hline UPTQ & 4.7 & 23.4 & 1.14 & 2050 & 7.0 & 1733 & 500 & 5.6 & 62.7 & 68.8 & 84.8 & 76.9 & 83.5 \\
\hline UPT & 4.7 & 23.4 & 1.14 & 2050 & 7.0 & 2050 & 500 & 6.8 & 63.6 & 70.8 & 86.1 & 70.9 & 79.4 \\
\hline$L=1 L L 7$ & 6.4 & 10.2 & 2.01 & 2050 & 10.0 & 1000 & 400 & 7.4 & 16.2 & 68.2 & 70.3 & 27.5 & 50.5 \\
\hline$L-1 L L 8$ & 6.4 & 10.2 & 2.01 & 2050 & 3.0 & 1000 & 400 & 7.7 & 14.1 & 60.9 & 62.6 & 24.5 & 54.0 \\
\hline$L \cdot I L L I$ & 6.4 & 11.9 & 2.01 & 2050 & 15.0 & 1000 & 400 & 5.0 & 18.9 & 50.4 & 54.3 & 58.0 & 78.8 \\
\hline$L \cdot 1 L L 11$ & 6.4 & 10.8 & 2.01 & 2050 & 15.0 & 1000 & 400 & 7.5 & 18.4 & 69.7 & 72.3 & 30.6 & 51.6 \\
\hline$L=1 L L 4$ & 9.5 & 12.5 & 2.01 & 2050 & 15.0 & 1000 & 400 & 7.6 & 24.0 & 70.1 & 74.0 & 39.2 & 57.4 \\
\hline$L=11 L 9$ & 6.4 & 10.5 & 2.01 & 2050 & 15.0 & 1000 & 400 & 7.9 & 22.1 & 81.7 & 84.1 & 24.8 & 38.5 \\
\hline$L \cdot I L L 12 A$ & 6.4 & 10.3 & 2.01 & 2050 & 10.0 & 1000 & 400 & 8.3 & 15.9 & 73.7 & 75.3 & 19.4 & 40.6 \\
\hline$L-1 L L 12$ & 6.4 & 12.8 & 2.01 & 2050 & 10.0 & 1000 & 400 & 11.6 & 18.5 & 82.6 & 83.7 & 9.4 & 25.1 \\
\hline L-ILL14 & 4.7 & 12.8 & 2.01 & 1680 & 7.0 & 1000 & 400 & 7.3 & 16.3 & 38.9 & 41.3 & 43.0 & 77.8 \\
\hline$L-1 L L 13$ & 4.7 & 12.8 & 2.01 & 1680 & 7.0 & 1000 & 400 & 5.6 & 20.1 & 50.3 & 54.5 & 56.3 & 78.0 \\
\hline ILLI & 6.5 & 26.4 & 2.74 & 2050 & 20.0 & 1000 & 400 & 16.0 & 50.5 & 69.9 & 79.7 & 39.4 & 57.7 \\
\hline ILLL2 & 2.1 & 16.0 & 2.74 & 2050 & 20.0 & 1000 & 400 & 7.0 & 53.7 & 80.7 & 89.4 & 56.3 & 64.7 \\
\hline ILL3 & 6.5 & 26.0 & 2.74 & 2050 & 20.0 & 1000 & 400 & 18.6 & 39.6 & 64.8 & 71.2 & 28.5 & 53.7 \\
\hline $1 L L 4$ & 1.5 & 18.6 & 2.74 & 2050 & 20.0 & 1000 & 400 & 6.3 & 34.4 & 56.3 & 64.8 & 66.0 & 80.9 \\
\hline
\end{tabular}


APPENDIX D

RESULTS FROM CONTINUOUS RESEARCH UNIT

$\mathrm{D}-1$ 


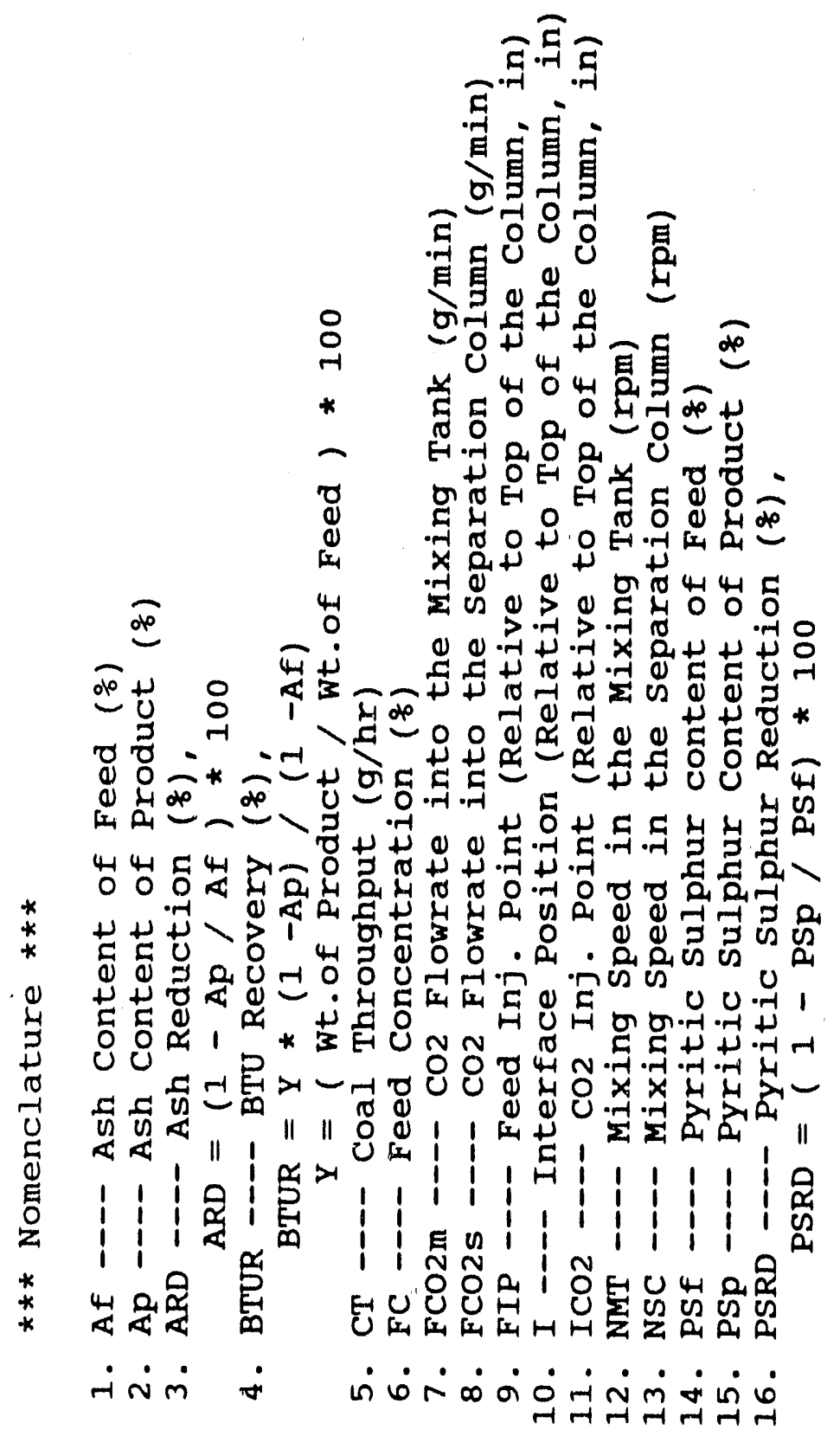




\begin{tabular}{|c|c|c|c|c|c|c|c|c|c|c|c|c|c|c|c|c|c|c|c|c|c|c|c|c|c|c|}
\hline $\begin{array}{l}\theta_{10}^{\circ} \\
\underbrace{\circ}_{0}\end{array}$ & $\begin{array}{l}\infty \\
\dot{0} \\
N\end{array}$ & $\begin{array}{l}\infty \\
\stackrel{0}{N}\end{array}$ & $\begin{array}{l}0 \\
\infty \\
1\end{array}$ & $\begin{array}{l}0 \\
\infty \\
1\end{array}$ & $\begin{array}{l}0 \\
\infty \\
\infty\end{array}$ & i & I & 11 & & $i$ & 11 & I & 11 & & 1 & i & i & i & I & i & ! & I & I & 1 & i & \\
\hline $\begin{array}{l}\Omega_{1} \text { of } \\
\mathrm{S}^{2}\end{array}$ & $\begin{array}{l}a \\
m \\
\dot{0}\end{array}$ & $\begin{array}{l}a \\
m \\
\dot{0}\end{array}$ & $\stackrel{n}{m}$ & $\begin{array}{l}0 \\
m \\
0\end{array}$ & $\begin{array}{l}\tilde{m} \\
\dot{0}\end{array}$ & $i$ & 1 & 11 & & $i$ & 1 & 11 & 11 & i & i & i & i & 1 & 1 & i & I & i & i & i & 1 & \\
\hline $\begin{array}{l}4-1 \text { of } \\
\text { S } \\
\text { ص }\end{array}$ & $\dot{n}$ & $\dot{H}$ & $\dot{r}$ & $\dot{H}$ & $\dot{n}$ & 1 & ! & $1 !$ & & 1 & i & 11 & 11 & ! & I & i & ! & 1 & I & i & i & i & i & i & i & 1 \\
\hline$\hat{\alpha}_{\alpha} d p$ & $N$ & & $\stackrel{n}{n}$ & $\pi$ & $\pi$ & $\sigma:$ & 6 & 0 & & ? & $\tilde{b}$ & $\hat{b}^{n}$ & $\tilde{6}$ & $\begin{array}{l}n \\
0\end{array}$ & $\begin{array}{ll}6 \\
6\end{array}$ & $6:$ & 6 & vi: & 6 & 65 & 0 & $\begin{array}{l}\infty \\
n \\
n\end{array}$ & $\begin{array}{l}0 \\
6\end{array}$ & ô & $\underline{\varphi}$ & กั \\
\hline م्र & $\dot{0}$ & $\stackrel{+1}{+}$ & $\dot{m}$ & $\stackrel{n}{m}$ & $\begin{array}{r}\sim \\
\dot{m}\end{array}$ & in & a & & & ن & & & & - & ' & 'ं & & m & $\dot{0}$ & $\Omega$ & $\dot{0}$ & $\dot{0}$ & $\dot{0}$ & ' & $\begin{array}{l}0 \\
\dot{1}\end{array}$ & $\therefore$ \\
\hline $4 d \infty$ & $\stackrel{N}{\dot{H}}$ & $\begin{array}{l}N \\
\dot{H}\end{array}$ & $\begin{array}{l}n \\
\dot{H}\end{array}$ & $\begin{array}{l}n \\
\dot{n}\end{array}$ & $\begin{array}{l}v \\
\dot{H}\end{array}$ & $\begin{array}{l}0 \\
\dot{0} \\
+1\end{array}$ & $\begin{array}{l}0 \\
0 \\
0 \\
-1\end{array}$ & $\begin{array}{l}0 \\
0 \\
0 \\
1\end{array}$ & & $\begin{array}{l}0 \\
\dot{0} \\
\dot{H}\end{array}$ & $\begin{array}{l}0 \\
6 \\
+1\end{array}$ & $\begin{array}{l}0 v \\
0 \\
0 \\
r\end{array}$ & $\begin{array}{l}0, v \\
\dot{0}, v \\
-1 .\end{array}$ & & $\begin{array}{l}0 \\
0 \\
0\end{array}$ & $\begin{array}{l}0 \\
0 \\
0 \\
-1\end{array}$ & $\begin{array}{l}0 \\
0 \\
0\end{array}$ & $\begin{array}{l}0 \\
\dot{0} \\
+1\end{array}$ & $\begin{array}{l}0 \\
0 \\
6 \\
-1\end{array}$ & $\dot{0}$ & $\begin{array}{l}0 \\
\dot{0} \\
-1\end{array}$ & $\dot{0}$ & $\begin{array}{l}0 \\
0 \\
0\end{array}$ & $\begin{array}{l}0 \\
\dot{0} \\
+1\end{array}$ & $\begin{array}{l}0 \\
0 \\
-1\end{array}$ & $\begin{array}{l}0 \\
0 \\
\dot{1}\end{array}$ \\
\hline $\begin{array}{l}\mathscr{S}_{1} \text { of } \\
P^{-1}\end{array}$ & $\stackrel{\varphi}{m}$ & gi & $\hat{m}$ & $\begin{array}{l}0 \\
+\end{array}$ & N & 인 & in & $\begin{array}{ll}6 & 15 \\
6 & 1\end{array}$ & & $\pi$ & ô & or 5 & Ln & م & ஸे & n & m & 용 & ar & $\infty ?$ & $\underset{\sim}{N}$ & గ-1 & N & in & nn & $\begin{array}{l}9 \\
6\end{array}$ \\
\hline 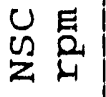 & $\begin{array}{l}0 \\
0 \\
\infty\end{array}$ & $\begin{array}{l}0 \\
0 \\
\infty\end{array}$ & $\begin{array}{l}0 \\
0 \\
\infty\end{array}$ & $\begin{array}{l}0 \\
0 \\
\infty\end{array}$ & $\begin{array}{l}0 \\
0 \\
\infty\end{array}$ & $\begin{array}{l}0 \\
0 \\
\infty\end{array}$ & $\begin{array}{l}0 \\
0 \\
\infty\end{array}$ & $\begin{array}{ll}0 & c \\
0 & c \\
\infty & 0\end{array}$ & & $\begin{array}{l}0 \\
0 \\
\infty\end{array}$ & $\stackrel{0}{0}_{0}^{0}$ & $\begin{array}{ll}0 & 5 \\
0 & 0 \\
\infty & 0\end{array}$ & $\begin{array}{ll}0 & c \\
0 & c \\
\infty & 0\end{array}$ & $\begin{array}{l}0 \\
\infty\end{array}$ & $\begin{array}{l}0 \\
0 \\
\infty\end{array}$ & $\begin{array}{l}0 \\
0 \\
\infty\end{array}$ & $\begin{array}{l}0 \\
0 \\
\infty\end{array}$ & $0_{\infty}^{0}$ & $\begin{array}{l}0 \\
0 \\
\infty\end{array}$ & 0 & $\begin{array}{l}0 \\
0 \\
\infty\end{array}$ & $\begin{array}{l}0 \\
0 \\
\infty\end{array}$ & $\begin{array}{l}0 \\
0 \\
\infty\end{array}$ & $\begin{array}{l}0 \\
0 \\
\infty\end{array}$ & $\begin{array}{l}0 \\
0 \\
\infty\end{array}$ & $\begin{array}{l}0 \\
0 \\
\infty\end{array}$ \\
\hline $\begin{array}{l}E-1 \\
\sum_{Z} \\
Z_{1}\end{array}$ & $i$ & $i$ & $i$ & $i$ & $i$ & $\begin{array}{l}0 \\
0 \\
0 \\
-1\end{array}$ & $\begin{array}{l}0 \\
0 \\
0 \\
-1\end{array}$ & $\begin{array}{ll}0 & c \\
0 & c \\
0 & 6 \\
-1 & 1\end{array}$ & & $\begin{array}{l}0 \\
0 \\
0 \\
-1\end{array}$ & 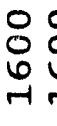 & $\begin{array}{ll}0 & 5 \\
0 & 5 \\
0 & 5 \\
7 & 5\end{array}$ & $\begin{array}{ll}0 & 5 \\
0 & 5 \\
0 & 5 \\
-1 & \end{array}$ & $\begin{array}{l}0 \\
0 \\
0 \\
-1\end{array}$ & $\begin{array}{l}0 \\
0 \\
0 \\
-1\end{array}$ & $\begin{array}{l}0 \\
0 \\
0 \\
-1\end{array}$ & $\begin{array}{l}0 \\
0 \\
0 \\
-1\end{array}$ & $\begin{array}{l}0 \\
0 \\
0 \\
-1\end{array}$ & $\begin{array}{l}0 \\
0 \\
0 \\
-1\end{array}$ & $\begin{array}{l}0 \\
0 \\
0 \\
1-1\end{array}$ & $\begin{array}{l}0 \\
0 \\
0 \\
-1\end{array}$ & $\begin{array}{l}0 \\
0 \\
0 \\
-1\end{array}$ & $\begin{array}{l}0 \\
0 \\
0 \\
-1\end{array}$ & $\begin{array}{l}0 \\
0 \\
0 \\
-1\end{array}$ & $\begin{array}{l}0 \\
0 \\
0 \\
-1\end{array}$ & $\begin{array}{l}0 \\
0 \\
0 \\
-1\end{array}$ \\
\hline 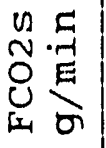 & $\begin{array}{l}0 \\
0 \\
\infty\end{array}$ & $\begin{array}{l}0 \\
0 \\
0 \\
-1\end{array}$ & $\begin{array}{l}0 \\
0 \\
N \\
-1\end{array}$ & $\begin{array}{l}\stackrel{0}{0} \\
\stackrel{\sim}{N} \\
-1\end{array}$ & $\begin{array}{l}0 \\
0 \\
N \\
-1\end{array}$ & $\begin{array}{l}0 \\
0 \\
0 \\
-1\end{array}$ & $\begin{array}{l}n \\
\infty \\
\infty \\
-1\end{array}$ & $\begin{array}{ll}0 & 0 \\
m & \sigma \\
m & 0\end{array}$ & & $\frac{0}{n}$ & $\begin{array}{l}n \\
\infty \\
0 \\
0 \\
r\end{array}$ & $\begin{array}{ll}0 & 5 \\
0 & 5 \\
\text { N } & \text { ? } \\
& \end{array}$ & $\begin{array}{ll}0 & 1 \\
0 & 0 \\
N & 0 \\
-1 & r\end{array}$ & $\begin{array}{l}n \\
\infty \\
0 \\
-1\end{array}$ & $\begin{array}{l}0 \\
0 \\
6 \\
-1\end{array}$ & $\begin{array}{l}n \\
\infty \\
\infty \\
+1\end{array}$ & $\frac{0}{m}$ & in & $\begin{array}{l}0 \\
n \\
n \\
n\end{array}$ & 0 & $\begin{array}{l}0 \\
\infty \\
\infty\end{array}$ & $\frac{0}{\sigma}$ & $\begin{array}{l}n \\
\infty \\
0 \\
-1\end{array}$ & $\begin{array}{l}0 \\
m \\
m\end{array}$ & $\begin{array}{l}0 \\
0 \\
\text {-1 }\end{array}$ & $\begin{array}{l}0 \\
10 \\
-1\end{array}$ \\
\hline 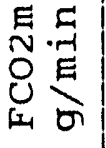 & i & $i$ & $\begin{array}{l}1 \\
1\end{array}$ & $\begin{array}{l}1 \\
1\end{array}$ & $i$ & 0 & $\begin{array}{l}n \\
r-1\end{array}$ & $\begin{array}{ll}0 & c \\
m & r \\
N & n\end{array}$ & & $\begin{array}{c}0 \\
m \\
N\end{array}$ & $\begin{array}{l}n \\
-1 \\
-1\end{array}$ & 00 & $\begin{array}{l}01 \\
r \\
r\end{array}$ & $\frac{n}{-1}$ & 0 & $\stackrel{n}{\pi}$ & $\begin{array}{r}0 \\
m\end{array}$ & $\begin{array}{l}0 \\
\text { in } \\
m\end{array}$ & $\begin{array}{l}0 \\
n \\
m\end{array}$ & $\begin{array}{l}0 \\
\text { in } \\
m\end{array}$ & $\begin{array}{l}0 \\
\text { in } \\
m\end{array}$ & $\begin{array}{c}o \\
m \\
w\end{array}$ & नी & $\stackrel{0}{10}$ & $\begin{array}{l}0 \\
0 \\
r-1\end{array}$ & $\begin{array}{l}0 \\
\text { in }\end{array}$ \\
\hline$H$. & $\underset{-1}{N}$ & r & $\stackrel{N}{N}$ & $\stackrel{N}{-1}$ & $\stackrel{N}{-1}$ & 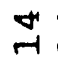 & $\stackrel{4}{-1}$ & $\begin{array}{ll}4 \\
4-1\end{array}$ & $\frac{d}{-1}$ & $\stackrel{+}{\pi}$ & H. & H. & $\stackrel{\nabla r}{r}$ & $r$ & $\begin{array}{r}4 \\
-1\end{array}$ & $\stackrel{+}{-1}$ & & $\begin{array}{l}4 \\
4\end{array}$ & 感 & $\overrightarrow{4}$ & $\begin{array}{r}+1 \\
-1\end{array}$ & $\stackrel{-1}{+1}$ & H & $\infty$ & $\infty$ & 6 \\
\hline$\underset{H}{D_{1}} \cdot \vec{C}$ & i & 1 & 1 & 1 & $i$ & $\underset{-1}{0}$ & $\begin{array}{l}0 \\
-1\end{array}$ & $\begin{array}{ll}0 & 6 \\
-1 & \end{array}$ & $\begin{array}{c}0 \\
-1\end{array}$ & $\stackrel{6}{n}$ & $\begin{array}{l}0 \\
-1\end{array}$ & $\begin{array}{l}0 \\
-1\end{array}$ & $\begin{array}{l}0 \\
-1\end{array}$ & $\underset{-1}{0}$ & $\stackrel{6}{0}$ & $\stackrel{0}{n}$ & $\begin{array}{l}0 \\
-1\end{array}$ & $\underset{-1}{0}$ & $\begin{array}{l}0 \\
-1\end{array}$ & $\begin{array}{l}0 \\
-1\end{array}$ & $\begin{array}{l}0 \\
-1\end{array}$ & $\begin{array}{l}0 \\
-1\end{array}$ & $\stackrel{6}{-1}$ & $\begin{array}{l}0 \\
-1\end{array}$ & & $\stackrel{6}{-1}$ \\
\hline$\bigcup_{L_{1}}^{U}$ of & & $\dot{q}$ & $\dot{p}$ & or & & $\begin{array}{l}0 \\
\dot{*}\end{array}$ & & 00 & & $\dot{8}$ & $\dot{+}$ & $\dot{\sigma}$ & & & $\dot{r}$ & $\dot{r}$ & & $\dot{r}$ & $\dot{\sigma}$ & & $\dot{\sigma}$ & $\nabla^{\prime}$ & $\sigma$ & a & & a \\
\hline E & $\begin{array}{l}n \\
10\end{array}$ & ป & $\stackrel{\oplus}{m}$ & $\stackrel{-1}{6}$ & $\frac{1}{1}$ & $\begin{array}{l}4 \\
10\end{array}$ & in & $\begin{array}{ll}4 & 5 \\
\text { L } & 5 \\
\text { L } & 5\end{array}$ & & $\begin{array}{l}10 \\
6 \\
10\end{array}$ & $\begin{array}{l}n \\
6 \\
\text { in }\end{array}$ & 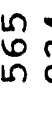 & $\begin{array}{l}+1 \\
\text { N } \\
\text { o }\end{array}$ & \begin{tabular}{l}
\multirow{N}{*}{} \\
$\sigma$
\end{tabular} & $\begin{array}{l}\infty \\
0 \\
+1 \\
-1\end{array}$ & $\begin{array}{l}\infty \\
0 \\
-1 \\
r\end{array}$ & $\begin{array}{l}\infty \\
0 \\
-1 \\
-1\end{array}$ & $\underset{1}{\infty}$ & $\begin{array}{l}\infty \\
-1 \\
0\end{array}$ & $\begin{array}{l}\infty \\
-1 \\
0\end{array}$ & $\begin{array}{l}m \\
\infty \\
0 \\
-1\end{array}$ & $\begin{array}{l}m \\
\infty \\
0 \\
m\end{array}$ & $\begin{array}{l}m \\
\infty \\
0\end{array}$ & $\begin{array}{l}0 \\
0 \\
6\end{array}$ & $\begin{array}{l}0 \\
0 \\
0\end{array}$ & $\begin{array}{l}0 \\
0 \\
0\end{array}$ \\
\hline $\begin{array}{ll}E-1 & 0 \\
\omega s & z \\
n & \end{array}$ & $\stackrel{n-1}{m}$ & & $m$ & $\stackrel{+}{m}$ & $m$ & n & $\tilde{m}$ & $\begin{array}{l}m \\
\text { in }\end{array}$ & ñ & in & in & ก) & م & ஸn & in & in & n) & in & & $\hat{i n}$ & $\hat{n}$ & (n) & in & a & $\begin{array}{l}\sigma \\
\text { in }\end{array}$ & a \\
\hline
\end{tabular}




\begin{tabular}{|c|c|c|c|c|c|c|}
\hline 111 & $\begin{array}{llllll}1 & 1 & 1 & 1 & 1 & 1\end{array}$ & 11 & 111 & 11 & 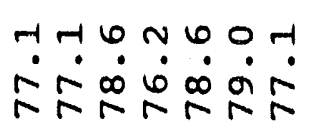 & 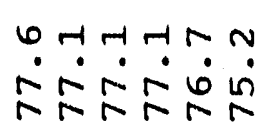 \\
\hline 111 & 111111 & 11 & 111 & 11 & 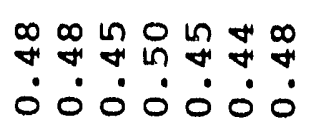 & 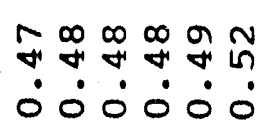 \\
\hline 111 & $\begin{array}{llllll}1 & 1 & 1 & 1 & 1 & 1\end{array}$ & i i & 111 & 1 i & 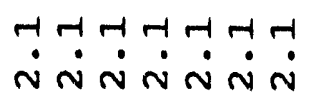 & 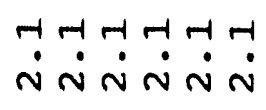 \\
\hline రิ & Oด & in & 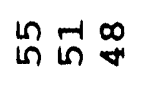 & in & 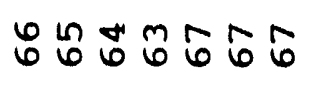 & ڤ \\
\hline ف & مُ & $\ddot{n}$ & 華 & 0. & 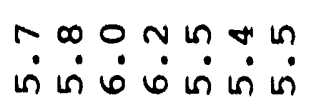 & 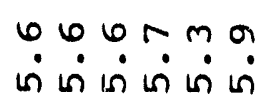 \\
\hline $\begin{array}{lll}0 & 0 & 0 \\
\dot{0} & \dot{0} & \dot{0} \\
-1 & 0 & -1\end{array}$ & 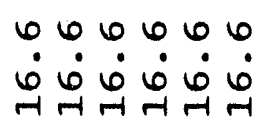 & $\begin{array}{ll}0 & 0 \\
\dot{0} & \dot{0} \\
-1 & \stackrel{-1}{0}\end{array}$ & $\begin{array}{lll}0 & 0 & 0 \\
\dot{0} & \dot{0} & \dot{0} \\
-1 & \sim & \sim\end{array}$ & $\begin{array}{ll}0 & 0 \\
\dot{0} & 0 \\
-1 & 0\end{array}$ & $\begin{array}{lllllll}0 & 0 & 0 & 0 & 0 & 0 & 0 \\
\dot{0} & \dot{0} & \dot{0} & \dot{0} & \dot{0} & \dot{0} & \dot{0}\end{array}$ & $\begin{array}{llllll}0 & 0 & 0 & 0 & 0 & 0 \\
\dot{0} & \dot{0} & \dot{0} & \dot{0} & \dot{0} & 0 \\
-1 & -1 & -1 & -1 & -1 & -1\end{array}$ \\
\hline$\stackrel{n}{r} \underset{\pi}{n}$ & \begin{tabular}{llll}
0 & 0 & 0 & \multicolumn{1}{c}{}
\end{tabular} & $\mathfrak{n} g$ & 두요요 & $\hat{\infty}_{+\infty}^{\infty}$ & 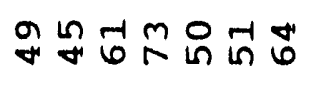 & 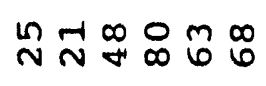 \\
\hline $\begin{array}{lll}0 & 0 \\
0 & 0 & 0 \\
\infty & \infty & \infty \\
\infty & \infty\end{array}$ & $\begin{array}{llllll}\circ & 0 & 0 & 0 & 0 & 0 \\
\circ & 0 & 0 & 0 & 0 & 0 \\
\infty & 0 & \infty & \infty & \infty & \infty\end{array}$ & $\begin{array}{ll}0 & 0 \\
0 & 0 \\
\infty & \infty\end{array}$ & $\begin{array}{l}\circ: 0 \\
\circ: \\
0\end{array}$ & $\begin{array}{ll}0 & 0 \\
0 & 0 \\
\infty & \infty\end{array}$ & $\begin{array}{lllllll}0 & 0 & 0 & 0 & 0 & 0 & 0 \\
0 & 0 & 0 & 0 & 0 & 0 & 0 \\
\infty & \infty & \infty & \infty & \infty & \infty & \infty\end{array}$ & 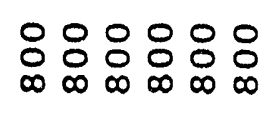 \\
\hline $\begin{array}{lll}0 & 0 & 0 \\
0 & 0 & 0 \\
0 & 0 & 0 \\
-1 & -1 & -1\end{array}$ & 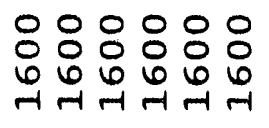 & $\begin{array}{ll}0 & 0 \\
0 & 0 \\
0 & 0 \\
-1 & 7\end{array}$ & 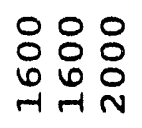 & $\begin{array}{ll}0 & 0 \\
0 & 0 \\
0 & 0 \\
-1 & 0\end{array}$ & $\begin{array}{lllllll}\circ & 0 & 0 & 0 & 0 & 0 & 0 \\
\circ & 0 & 0 & 0 & 8 & 0 & 0 \\
0 & 0 & 0 & 0 & 0 & 0 & 0 \\
-1 & -1 & -1 & -1 & -1 & -1 & -1\end{array}$ & $\begin{array}{llllll}0 & 0 & 0 & 0 & 0 & 0 \\
0 & 0 & 0 & 0 & 0 & 0 \\
0 & 0 & 0 & 0 & 0 & 0 \\
-1 & -1 & -1 & -1 & -1 & -1\end{array}$ \\
\hline $\begin{array}{lll}0 & 0 & 0 \\
0 & 0 & 0 \\
-1 & 0 & -1 \\
-1\end{array}$ & 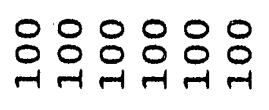 & 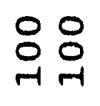 & 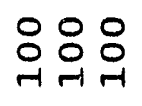 & $\begin{array}{ll}0 & 0 \\
\circ & 0 \\
-1 & -1\end{array}$ & 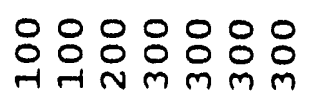 & 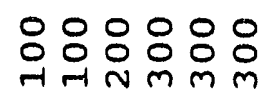 \\
\hline $\begin{array}{l}0 \\
0 \\
0\end{array}$ & $\begin{array}{l}O \\
\circ\end{array}$ & $\begin{array}{ll}0 & 0 \\
0 & 0 \\
ㄱ & \circ\end{array}$ & 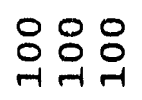 & O & $\begin{array}{l}\circ \\
\circ\end{array}$ & $\begin{array}{l}\circ \\
\circ\end{array}$ \\
\hline $\begin{array}{lll}\infty 0 & 0 \\
r & 0\end{array}$ & $\infty \infty \infty \underset{\sim}{0} \underset{\sim}{\sim} \underset{-1}{N}$ & $\infty \infty$ & $\infty \infty \infty$ & 에 & 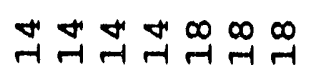 & 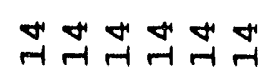 \\
\hline $\begin{array}{lll}0 & 0 & 0 \\
-1 & -1 & -1\end{array}$ & $\begin{array}{llllll}0 & 0 & 0 & 0 & 0 & 0 \\
-1 & -1 & -1 & -1 & -1 & -1\end{array}$ & $\stackrel{\circ}{N}$ & 융ํำ & $\begin{array}{ll}0 & 0 \\
-1 & 0\end{array}$ & 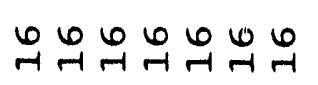 & 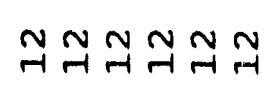 \\
\hline $\begin{array}{l}\infty \\
\dot{\sigma} \dot{\sim}\end{array}$ & $\begin{array}{llll}0 & 0 & 0 & 0 \\
\dot{\sigma} & 0 & 0 & 0\end{array}$ & $\begin{array}{ll}6 & 0 \\
\dot{\gamma} & \dot{\gamma}\end{array}$ & 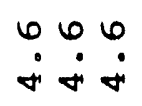 & $\stackrel{0}{\dot{\sigma}} \dot{\sigma}$ & 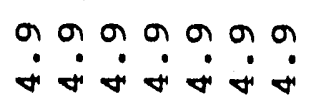 & $\begin{array}{lllll}0 & 0 & 0 & 0 & 0 \\
\dot{\sigma} & \dot{\sigma} & \dot{\sigma} & \dot{\sigma} & \dot{\sigma}\end{array}$ \\
\hline 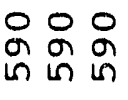 & 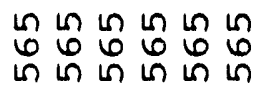 & 峦 & 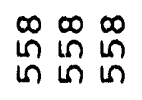 & $\begin{array}{l}\text { aे } \\
\text { ô } \\
\text { मn }\end{array}$ & 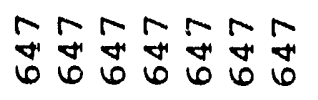 & 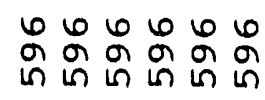 \\
\hline 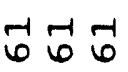 & 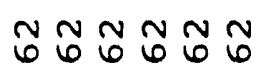 & छै & $\begin{array}{ll}\ln \\
0\end{array}$ & $\begin{array}{ll}\mathscr{0} & 6 \\
0\end{array}$ & $\hat{\sigma} \tilde{\sigma} \hat{\sigma} \tilde{6} \hat{\sigma}$ & $\begin{array}{lll}\infty & \infty & \infty \\
0 & 0 & 0\end{array}$ \\
\hline
\end{tabular}




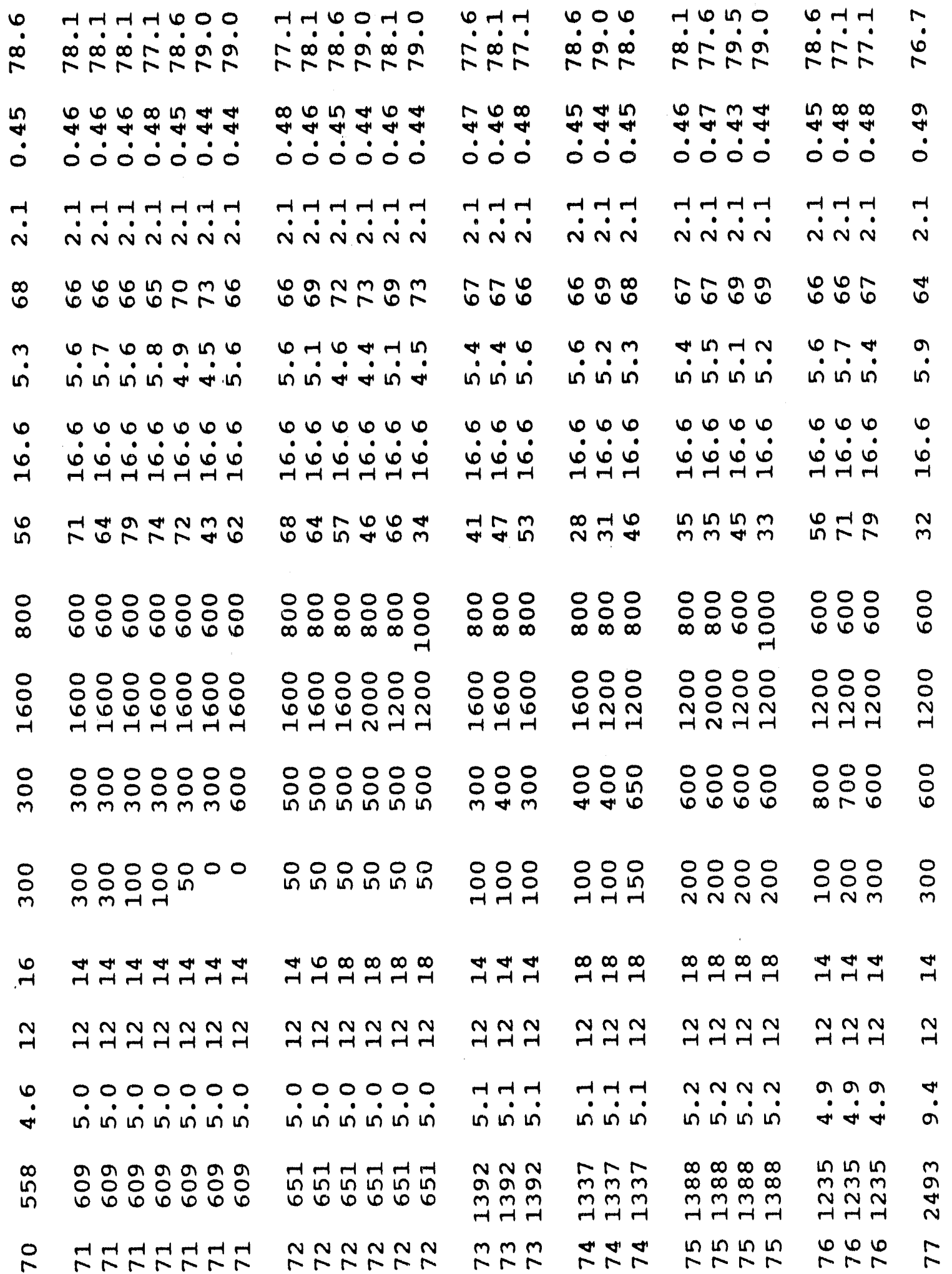


$\stackrel{m}{n} \mid$

เก !

$\dot{0}$

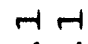

$\dot{v} \dot{v}$

-

$\forall a$

من

66

$\stackrel{\overrightarrow{0}}{\dot{0}}$

당

$\circ$
0

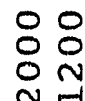

$\circ$
$\circ$
$\circ$

$\circ 0$
$\circ$
m 8

त

$\underset{H}{N}$

$m m$

욱 0

60

กิ์

$\sim$

$\infty \infty$

$r$ 
APPENDIX E

$1-1$ 


\section{GRINDING ENERGY CORRELATION}

Grinding energy per ton of coal was calculated using the following algorithm:

where

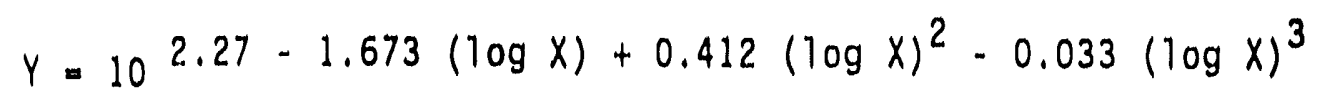

$$
\begin{aligned}
Y & =\text { grinding cost, } \$ / \text { ton } \\
X & =\text { particle size, micron } \\
\log & =\text { logarithm to the base } 10
\end{aligned}
$$

This algorithm was obtained by curve fitting a plot of specific energy vs. product size obtained from the following reference:

"Comminution and Energy Consumption, National Materials Advisory Board, Publication NMAB-364, National Academy Press, Washington, DC, 1981

This plot is provided on the following page. 


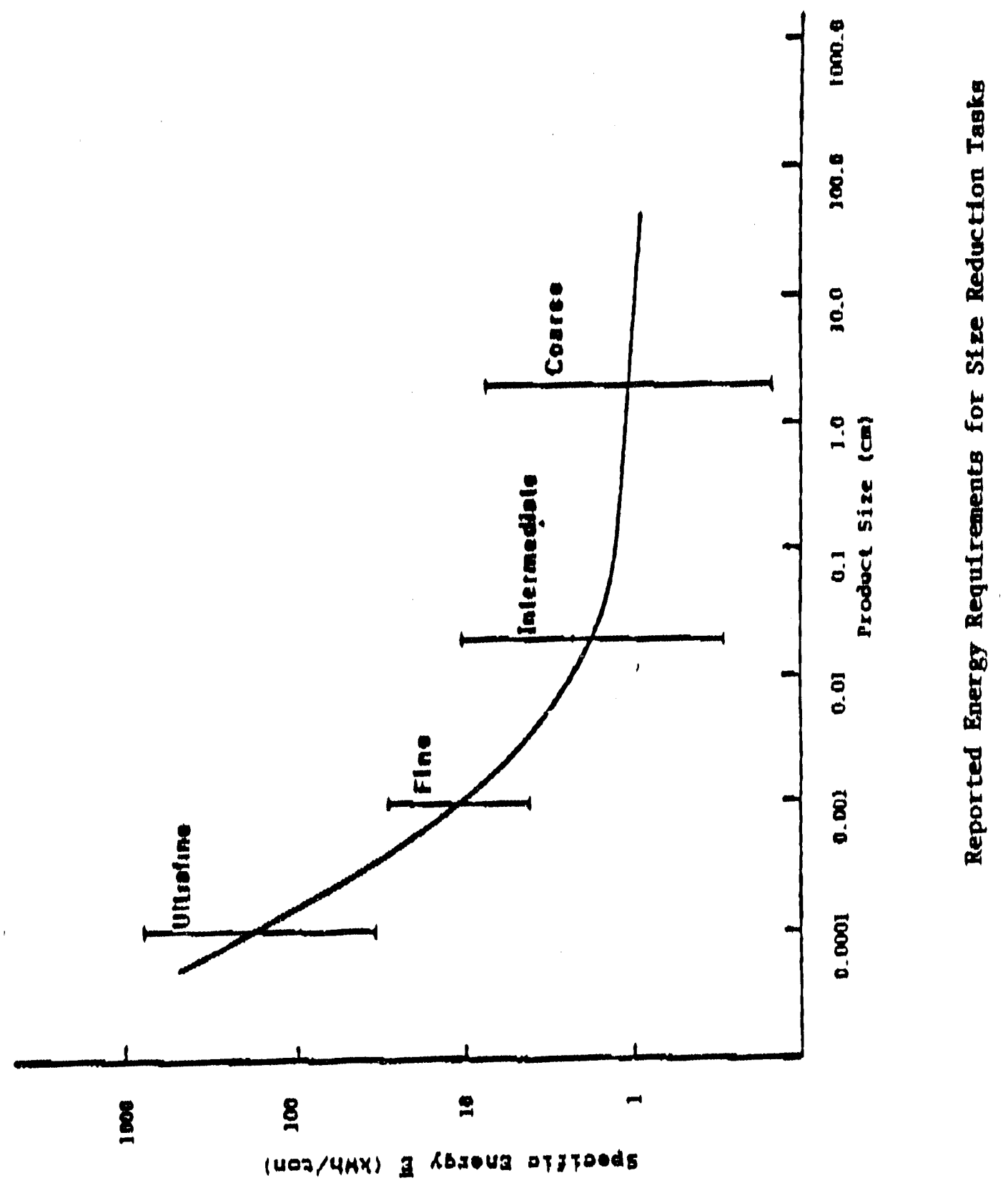

L-3 
DIMENSION DATA (50), R (1000), AN(1000), LEM(1000), WT(100),

$1 \quad \operatorname{SR}(1000), \operatorname{AS}(100), \operatorname{LES}(1000), \operatorname{DIAM}(12,80), \operatorname{AR}(12,80), \operatorname{VEL}(12,80)$

1 WTS $(100), \operatorname{VMI}(1000), \operatorname{VSI}(1000), \mathrm{CI}(12), \mathrm{RHO}(12), \mathrm{C2}(12), \mathrm{CL}(11)$ INTEGER N, P, $Q, Q A, J 1, J 2$, IND1, IND2, N1

1 REAL M, MS

OPEN (5, FILE $=$ ' INPUT. DAT')

$\operatorname{OPEN}(6, F I I E=$ ' OUTP. DAT')

OPEN (7, FILE = ' FLOWST.DAT')

110 FORMAT (24X' 'LICADO PLANT SIMULATION')

WRITE $(6,110)$

111 FORMAT $(1 \mathrm{X})$

$$
\text { FORMAT ( } 1 \mathrm{X} \text { ) }
$$

DATA A $/ 0.0398 /$ M $/ 0.0074 /$, PS $/ 0.0056 /$ OS $/ 0.0048 /$,

$1 \mathrm{F1} / 0.90 /, \mathrm{F} 2 / 0.90 \%, \mathrm{SF} / 0.0001 / \mathrm{CA} / 2000.0 \% \mathrm{Sz} / 73.0 \%$

$1 \quad$ SCONC $/ 0.1000 / \%$ TM $/ 100.0 /$ TS $/ 500 / \%$ X1 $/ 0.900 /, Y / 0.995 /$,

$1 \quad z / 0.002 /, z 2 / 0.990 /, z 3 / 0.005 / \%$ PR2 $/ 850 . \%$ PRí $/ 14.7 /$

$1 \quad \mathrm{MS} / 1200 . /$ LR $/ 0.500 \%$ X2 $/ 0.999 \%, \mathrm{~F} 4 / 0.001 / \mathrm{F} 3 / 0.95 /, \mathrm{Y} 2 / 0.0001 /$

1 RHO (1) $/ 47.4 /, \mathrm{RHO}(2) / 61.7 /, \mathrm{RHO}(3) / 48.7 /, \mathrm{RHO}(4) / 62.4 /, \mathrm{RHO}(5) / 62.4 /$,

120 WRITE $(6,120)$

130 WRITE $(6,130)$

130 FORMAT ( $6 \mathrm{X}$, 'ASH', 5X,'MOISTURE', $2 \mathrm{X}$, 'PYR SUL', 3X, 'ORG SUL',

1 2X,'SULFATES', $2 X^{\prime}$, 'FRACT ASH', '2X,'FRAC PSUL')

WRITE $(6,140) A, M, P S, O S, S F, F 1, F 2$

160

\section{IALUE'}

FORMAT (7F10.4)

WRITE $(6,160)$

FORMAT (5X,' CLEAN COAL PRODUCTION RATE, LB/HR', 10X,'COAL HEATING V

WRITE $(6,170) \mathrm{CA}, \mathrm{HV}$

170 FORMAT (15X,1F10.1,23X,1F10.2)

171 WRITE $(6,171)$

180 WRITE $(6,180)$

180 FORMAT (26X', PLANT CHARACTERISTICS')

200 FORMAT (IX,'PART.SIZE', 1X,'SIURRY CONC', 1X,'MTXER TIME',

1 IX,'SEPAR TIME', IX,'FR COAL/CO2', $1 \mathrm{X},{ }^{\prime} \mathrm{FR} \mathrm{CO}^{\prime} / \mathrm{CO}^{\prime}$ ')

210 FORMAT (6F11.4)

230 FORMAT('FR H2O/CO2', IX, 'FRH2O/DEW', IX,'FR CO2/H2O',

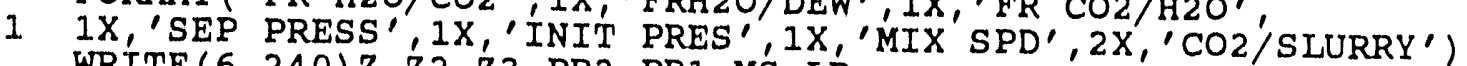

$240 \quad$ WRITE $(6,240) \mathrm{Z}, \mathrm{Z2}, \mathrm{Z3}, \mathrm{PR} 2, \mathrm{PR} 1, \mathrm{MS}, \mathrm{IR}$

WRITE $(6,23 i)$ F10.4,1F12.1,1F9.1,1F11.1,1F8.4)

231 FORMAT( $1 X$, 'COAL FRAC SEP AT FILTER')

WRITE $(6,232) \times 2$

232 FORMAT (6X, IF $=0.4)$

C

CALCULATION OF GRINDING/WATER SLURRY SYSTEM

SLURRY CONCENTRATION $(S C O N C)=C /(C+W)$

$F A=(1,-F 1.) \star A$

$\mathrm{FS}=(1,-\mathrm{F} 2) \star \mathrm{PS}$

$F M=(1,-F 3) \star M$

$\mathrm{Cl}(1)=\mathrm{CA} / \mathrm{X} 1+\mathrm{CA} *(\mathrm{~F} 1 * \mathrm{~A}+\mathrm{F} 2 * \mathrm{PS}+\mathrm{F} 3 * \mathrm{M}) / \mathrm{X} 1$

DO $205 \mathrm{Nl}=1,10$

$205 \quad \mathrm{CL}(\mathrm{N} 1+1)=\mathrm{CA} / \mathrm{X} 1+\mathrm{CL}(\mathrm{N} 1) *(\mathrm{~F} 1 * \mathrm{~A}+\mathrm{F} 2 * \mathrm{PS}+\mathrm{F} 3 * \mathrm{M}) / \mathrm{XI}$

$\mathrm{C}=\mathrm{CL}(11)$

The above "do loop" is used to iteratively calculate the coal feed
$W=C *(1 .-S C O N C) / S C O N C$ 

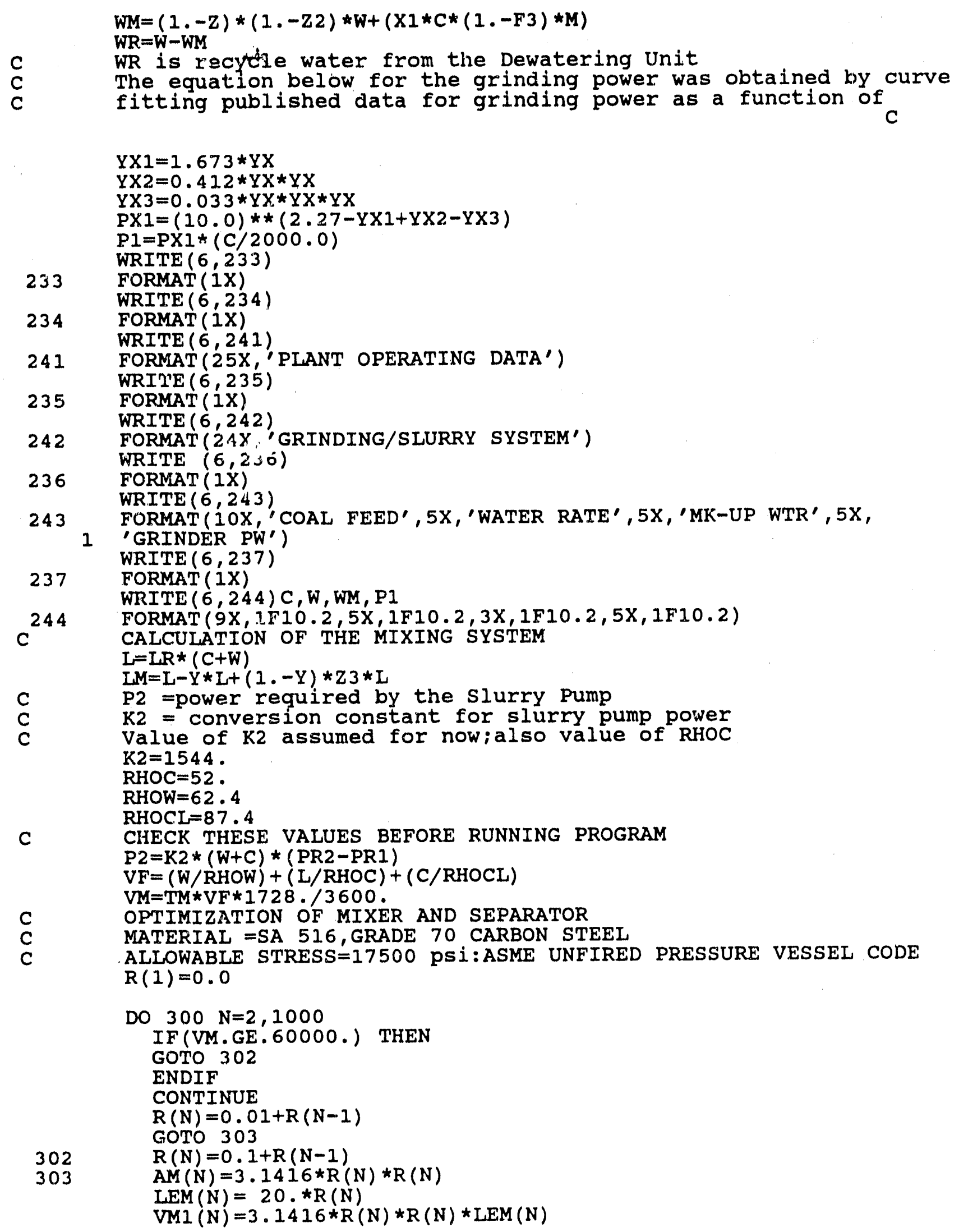


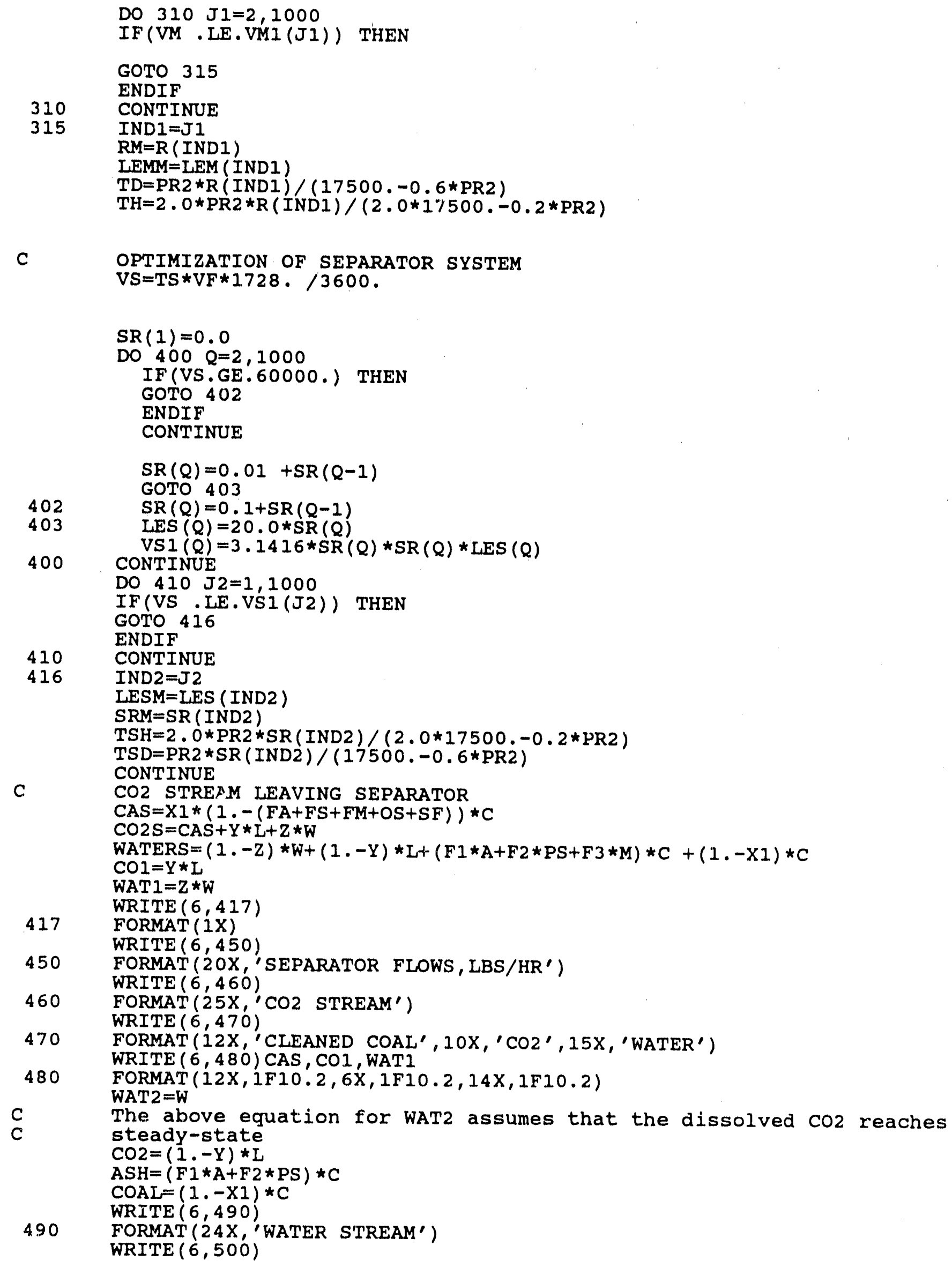




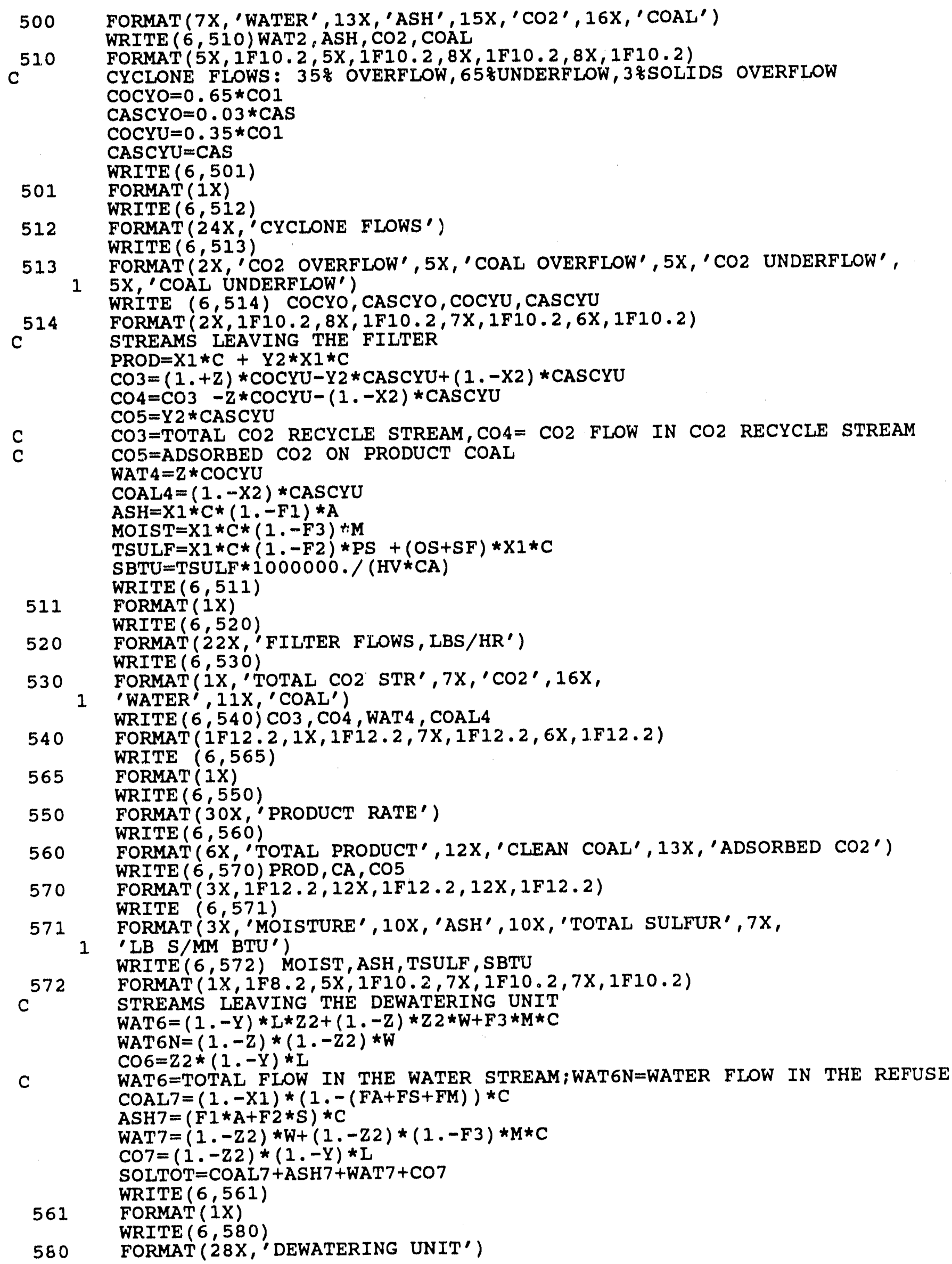




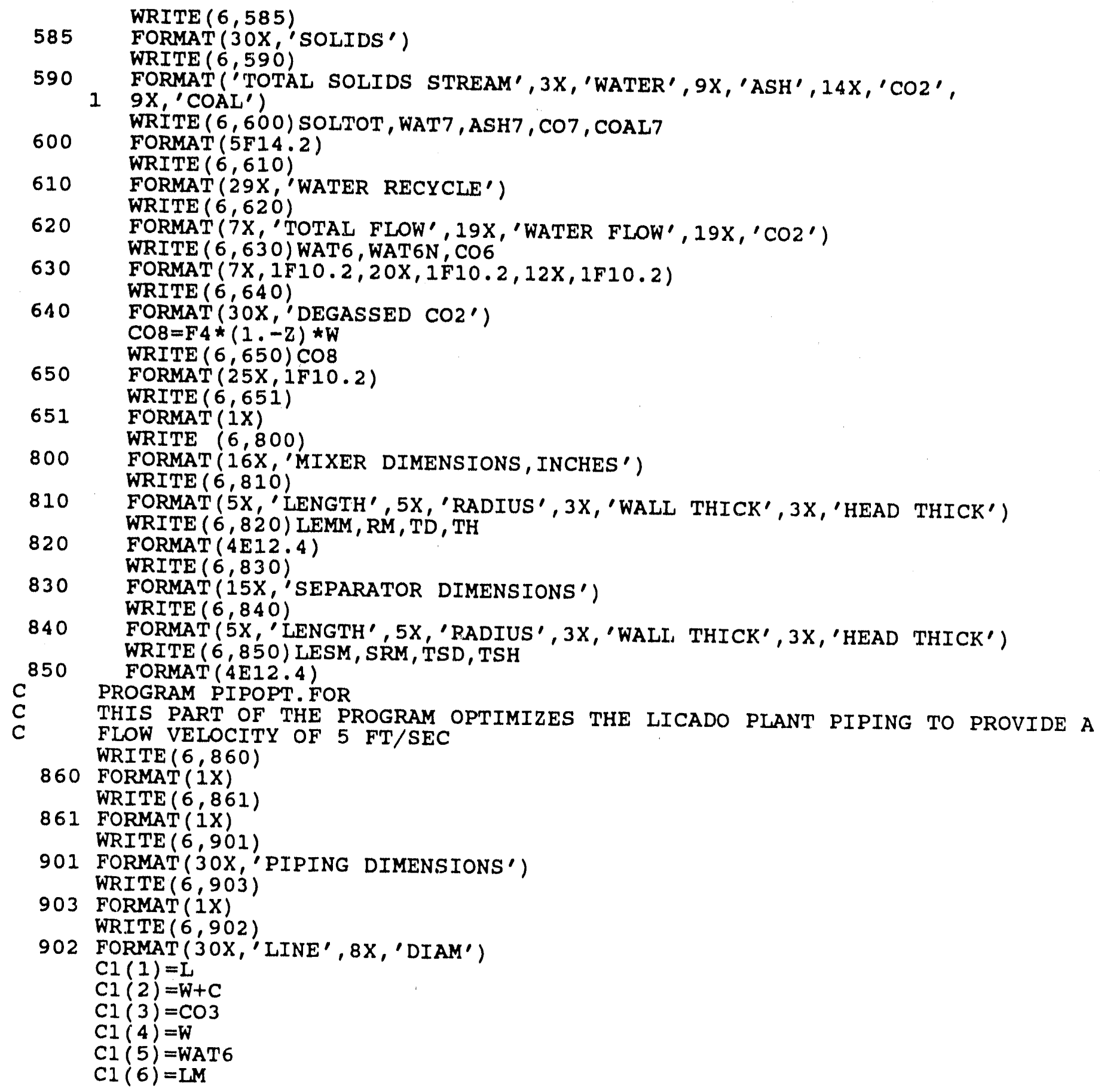


911 FORMAT (30X, 1I2, 4X, 1F10.2)

920 CONTINUE

WRITE $(6,93.1)$

931. FORMAT ( $2 \mathrm{X})$

WRITE $(6,932)$

932 FORMAT ( $20 \mathrm{X}$, 'LINE $1=\mathrm{CO} 2$ FROM CYCLONE TO MIXER')

WRITE $(6,933)$

933 FORMAT ( $20 X$, 'LINE 2=FEED FROM SLURRY TANK TO MIXER')

WRITE $(6,934)$

934 FORMAT ( 2 ÓX,'LINE 3=CO2/COAL FROM SEPARATOR TO CYCLONE')

WRITE $(6,935)$

935 FORMAT ( $20 \mathrm{X}$,'LINE 4=WATER FROM RECYCLE TANK TO GRINDER')

WRITE $(6,936)$

936 FORMAT ( $20 X, '$ 'LINE 5=WATER FROM REFUSE LETDOWN TO RECYCLE TANK')

WRITE $(6,937)$

937 FORMAT ( $20 \mathrm{X}$, 'LINE 6=CO2 MAKE-UP LINE')

$\mathrm{AC}=\mathrm{A} * \mathrm{C}$

$\mathrm{SC}=(\mathrm{PS}+\mathrm{OS}+\mathrm{SF}) * \mathrm{C}$

$\mathrm{CM}=\mathrm{M} * \mathrm{C}$

$\mathrm{SRF}=\mathrm{F} 2 * \mathrm{PS} * \mathrm{C}$

$\mathrm{CO} 9=\mathrm{CO} 5+\mathrm{CO} 8$

CORCY $=$ COCYO+CO4

ASHR $=F 1 \star A \star C$

C

THIS SECTION WRITES A SEPARATE FILE, FLOWST.DAT, FOR TRANSFER OF

C THE DATA TO THE CADD SYSTEM

WRITE $(7,731)$

731 FORMAT (24X,'LICADO PLANT SIMULATION')

WRITE $(7,732)$

732 FORMAT (23X,'PITTSBURGH-BRUCETON COAL')

733 FORMAT (22X,'PRODUCTION RATE, LB/HR=',1F6.1)

WRITE $(7,710)$

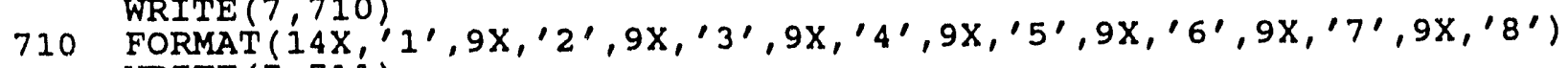

711 FORMAT( $\left(13 \mathrm{X}\right.$, 'FEED', $4 \mathrm{X},{ }^{\prime}$ GRNDR', 6X,'SLURRY',4X,'MIXER',4X,'CO2 RCY',

$14 \mathrm{X}$, 'SEP PR', $3 \mathrm{X}^{\prime}, \mathrm{SEP} \mathrm{RF}^{\prime}, 5 \mathrm{X}$, 'CYL OV')

WRITE $(7,712) \mathrm{C}, \mathrm{C}, \mathrm{C}, \mathrm{C}$

712 FORMAT('RAW COAL',E10.4,E10.4,E10.4,E10.4)

712 WRITE $(7,713)$ CA, COAL, CASCYO

713 FORMAT ('CLN COAL', 50X, 3E10.4)

WRITE $(7,714)$ CM, WR, W, W, WAT1, WAT2

714 FORMAT('WATER', 3X, 2E10.4,E10.4, E10.4, E10.4, 10X, 1E10.4)

WRITE $(7,715) \mathrm{L}, \mathrm{L}, \mathrm{CO} 1, \mathrm{CO} 2, \mathrm{COCYO}$

715 FORMAT ('CO2-1iq' ', 3OX, 1E10.4, 1E10.4, 1E10.4, 2E10.4)

WRITE $(7,716) \quad C O 5$

716 FORMAT ('CO2-gas ',50X, 1E10.4)

WRITE $(7,717)$ AC, AC, AC, AC, ASH, ASHR

717 FORMAT ('ASH', 5X, 4E10.4, 10X, 2E10.4)

WRITE $(7,718)$ 'SC, SC, SC, SC, TSULF, SRF

718 FORMAT('SULFUR', 2X,4E10.4, 10X, IE10.4,2E10.4)

WRITE $(7,719)$

719 FORMAT (1X)

WRITE $(7,720)$

720 FORMAT (1X)

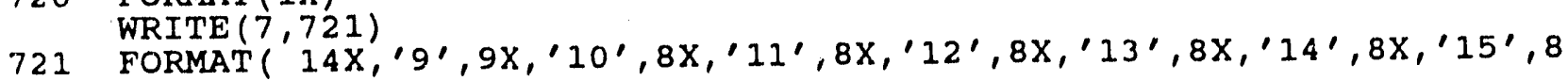
$\left.1 \mathrm{X},{ }^{\prime} 16^{\prime}\right)$

722 FORMAT $\left(10 X, X^{\prime}\right.$ 'PRODUCT', 3X,'FLTR LIQ', 2X,'REFUSE GAS', $1 X_{1}$, 'PROD GAS',

$12 \mathrm{X}$, 'COMPRESS', $3 \mathrm{X}$, 'REFUSE', 3X, 'RECXL WTR', $2 \mathrm{X}$, 'MK UP' WTR')

WRITE $(7,723)$

723 FORMAT('RAW COAL')

WRITE $(7,724)$ CA, COAL4, COAL7

724 FORMAT'('CLN COAL', 2EIO $0.4,30 X$, E10.4)

WRITE $(7,725)$ MOIST, WAT4, WAT $6 N$, WR, WM 
725 FORMAT ('WATER', 3X, 2E10.4, 30X, 3E10.4)

WRITE $(7,726) C 04, C 09, \mathrm{CO} 6$

726 FORMAT ('CO2-11g', 11X, 1E10.4, 20X, 1E10.4, 10X, 1E10.4)

WRITE $(7,727) \mathrm{CO} 5, \mathrm{CO}, \mathrm{CO} 5, \mathrm{CO} 7$

727 FORMAT ('CO2-gas', 1X, 1E10.4, 10X, 2E10.4, 10X, 1E10.4)

WRITE $(7,728)$ ASH, ÁSHR

728 FORMAT ('ASH', 5X, 1E10.4, 40X, 1E10.4)

WRITE $(7,729)$ TSULF, SRF

729 FORMAT('SULFUR', 2X, 1E10.4, 40X, 1E10.4)

CLOSE (UNIT $=7$ )

CLOSE (UNIT $=6$ )

CLOSE (UNIT $=5$ )

STOP

END 


\title{
LICADO PLANT SIMULATION
}

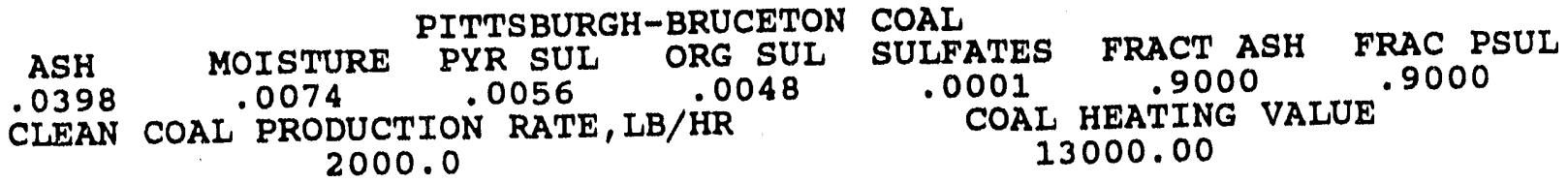

PIANT CHARACTERISTICS

PART.SIZE SLURRY CONC MIXER TIME SEPAR TIME FR COAL/CO2 FR $\mathrm{CO} 2 / \mathrm{CO}_{2}$

73.0000

FR H2O/CO2 FRH2O/DEW FR .002000 COAL FRAC

.9900 .0050

500.0000 .9000 .9950

SEP PRESS INIT PRES 850.0

14.7 $\begin{array}{lr}\text { IXPD } & \text { CO2/SLURR } \\ 1200.0 & .5000\end{array}$ .9990

\author{
PLANT OPERATING DATA \\ GRINDING/SLURRY SYSTEM \\ COAL FEED \\ WATER RATE \\ MK-UP WTR \\ GRINDER PW \\ 2347.11 \\ 21124.03 \\ 211.60 \\ 2.75
CLEANED COAL 2091.68 WATER

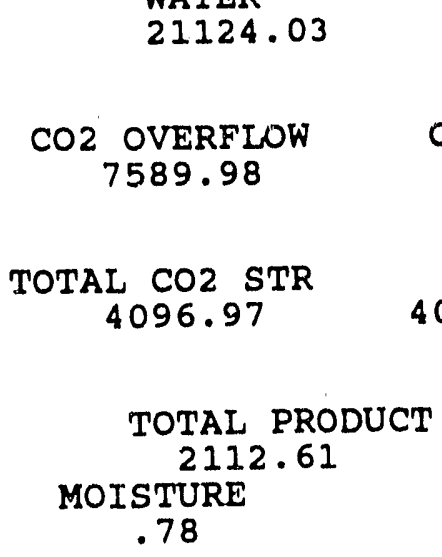
21124.03

TOTAL PRODUCT 2112.61 MOISTURE .78
ASH
8.41

ASH
8.41
TOTAL SOLIDS STREAM 529.47
TOTAL FLOW 20945.56 \\ SEPARATOR FLOWS, LBS/HR \\ CO2 STREAM \\ 11676.90 \\ WATER STREAM \\ 95.90 \\ $\mathrm{CO} 2$ \\ 58.68 \\ WATER \\ 42.25

\section{PRODUCT RATE} \\ CLEAN COAL \\ 2000.00 \\ TOTAL SULFUR \\ 11.53

$$
\begin{array}{lc}
\multicolumn{2}{c}{\text { DEWATERING UNIT }} \\
\text { SOLIDS } \\
\text { WATER } & \text { ASH } \\
211.25 & 84.07 \\
& \text { WATER RECYCLE } \\
& \multicolumn{2}{c}{\text { WATER FLOW }} \\
& 210.82 \\
& \text { DEGASSED CO2 } \\
& 21.08
\end{array}
$$

\section{DEWATERING UNIT} \\ MIXER DIMENSIONS, INCHES

$$
\text { LENGTH }
$$ \\ $.1536 \mathrm{E}+03$ \\ LENGTH \\ $.2640 \mathrm{E}+03$ \\ WALL THICK \\ $.3842 \mathrm{E}+00$ \\ $.7680 \mathrm{E}+01$ \\ SEPARATOR \\ RADIUS \\ $.1320 \mathrm{E}+02$ \\ DIMENSIONS \\ WALI THICK \\ . $6604 \mathrm{E}+00$ \\ HEAD THICK \\ $.3749 E+00$ \\ HEAD THICK \\ $.6443 \mathrm{E}+00$ \\ PIPING DIMENSIONS \\ ADSORBED $\mathrm{CO} 2$ \\ .21 \\ LB S/MM BTU \\ .44 \\ $\mathrm{CO} 2$ \\ .59 \\ COAL \\ 233.56 \\ $\mathrm{CO} 2$ \\ 58.09
}

E 


$\begin{array}{cr}\text { LINE } & \text { DIAM } \\ 1 & 2.00 \\ 2 & 2.00 \\ 3 & 1.00 \\ 4 & 2.00 \\ 5 & 2.00 \\ 6 & .50\end{array}$

LINE 1=CO2 FROM CYCLONE TO MIXER

LINE 2=FEED FROM SLURRY TANK TO MIXER

LINE 3=CO2/COAL FROM SEPARATOR TO CYCLONE

LINE 4=WATER FROM RECYCIE TANK TO GRINDER

LINE 5=WATER FROM REFUSE LETDOWN TO RECYCLE TANK

LINE $6=\mathrm{CO} 2$ MAKE-UP LINE 
APPENDIX $F$

F-1 


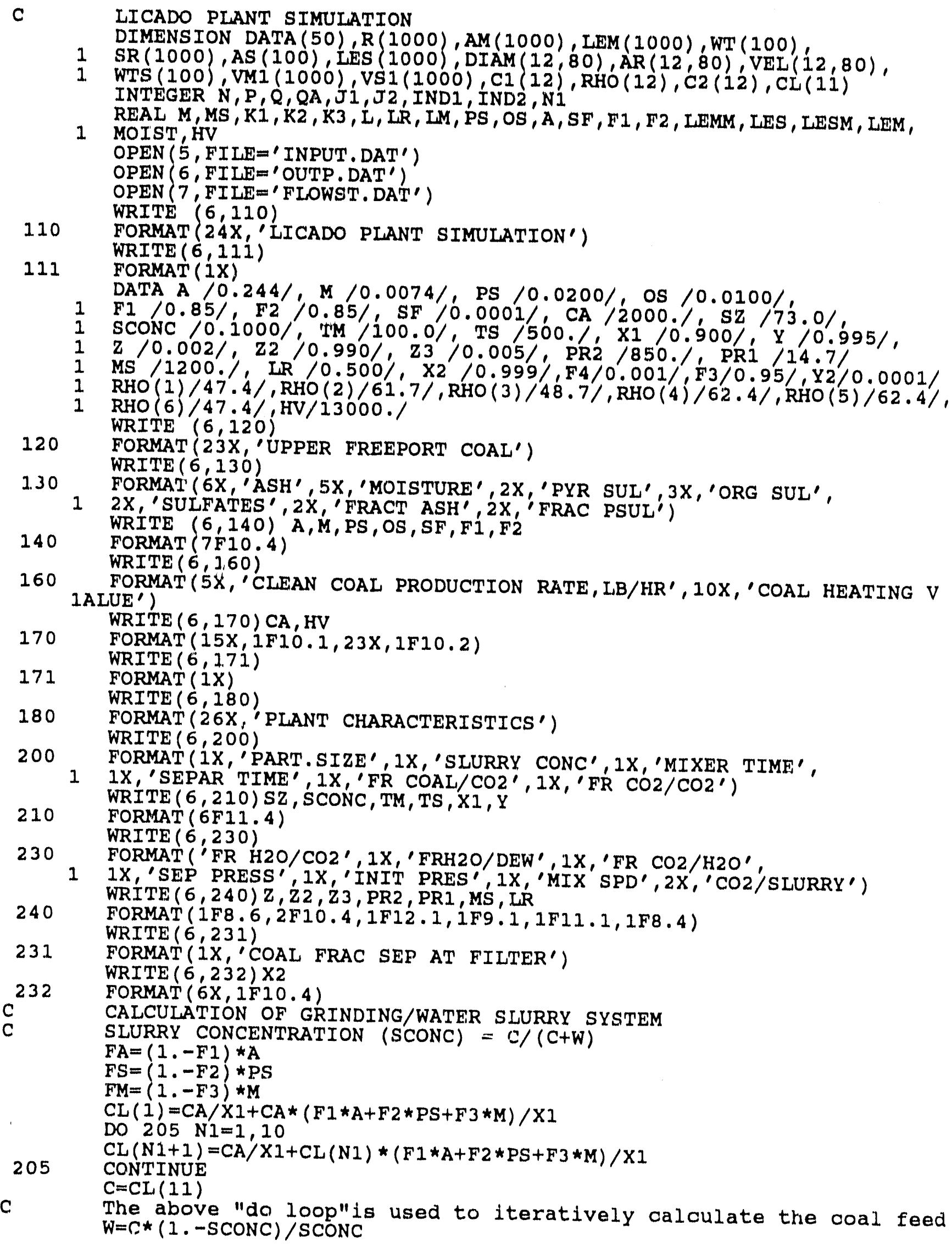




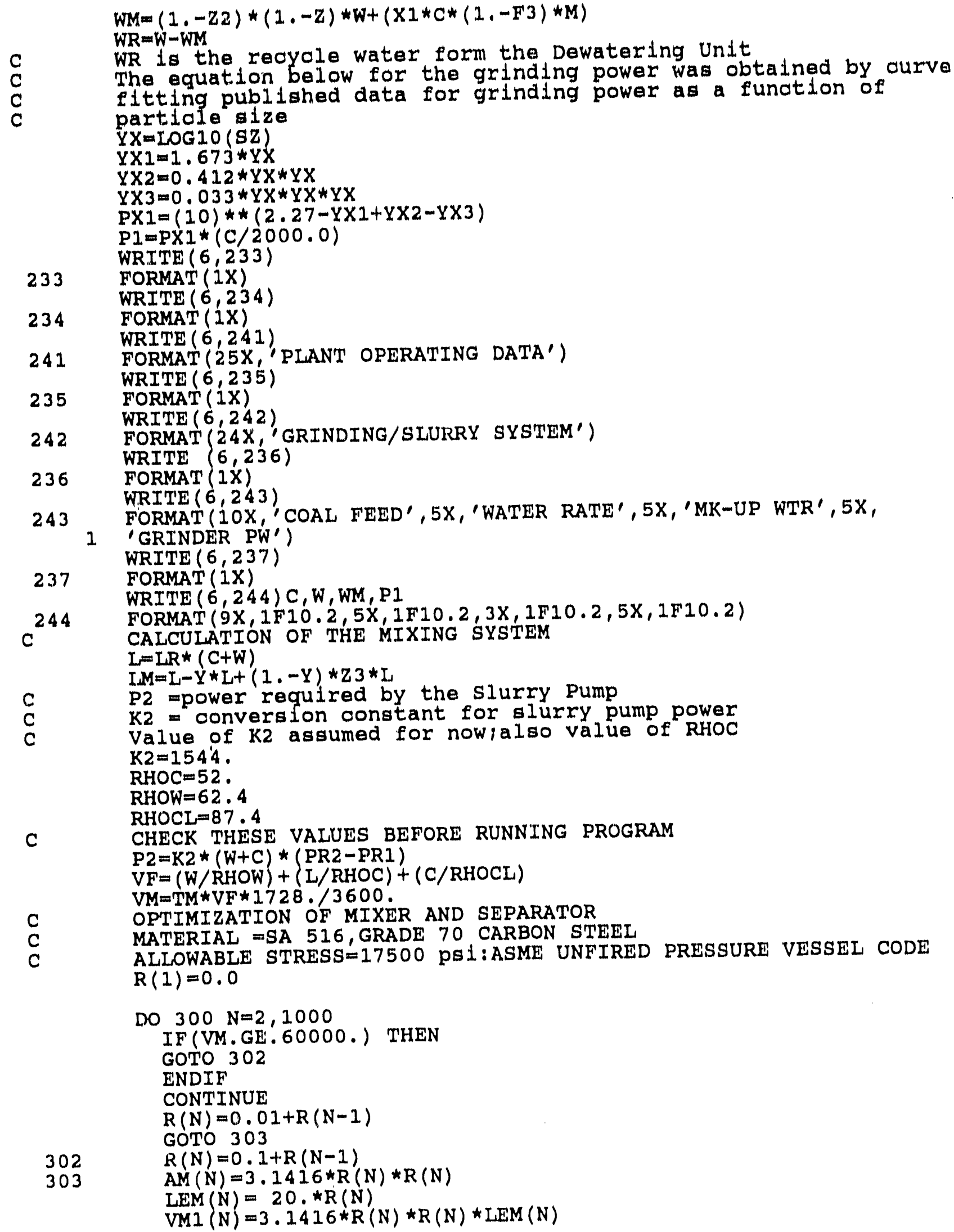




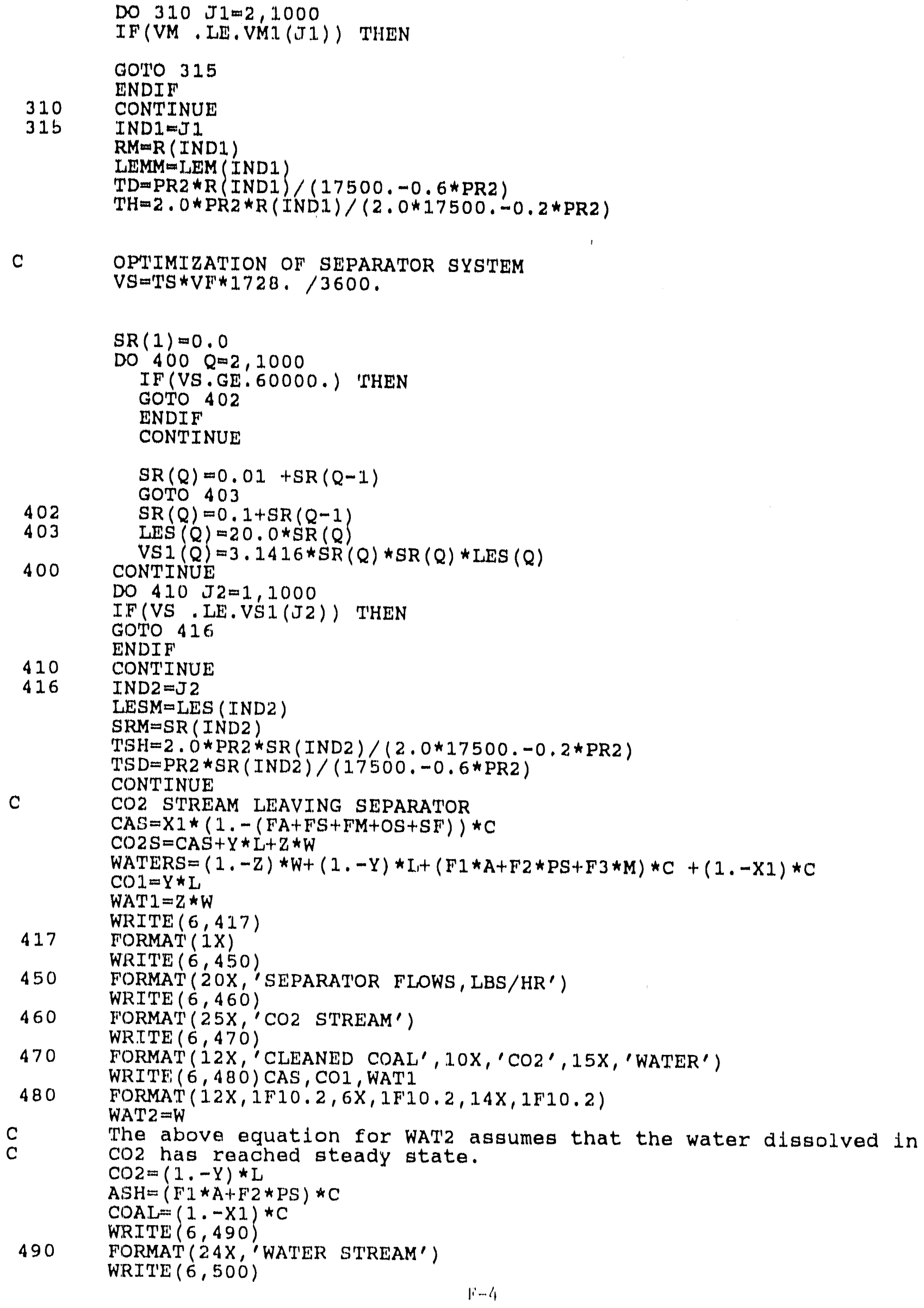




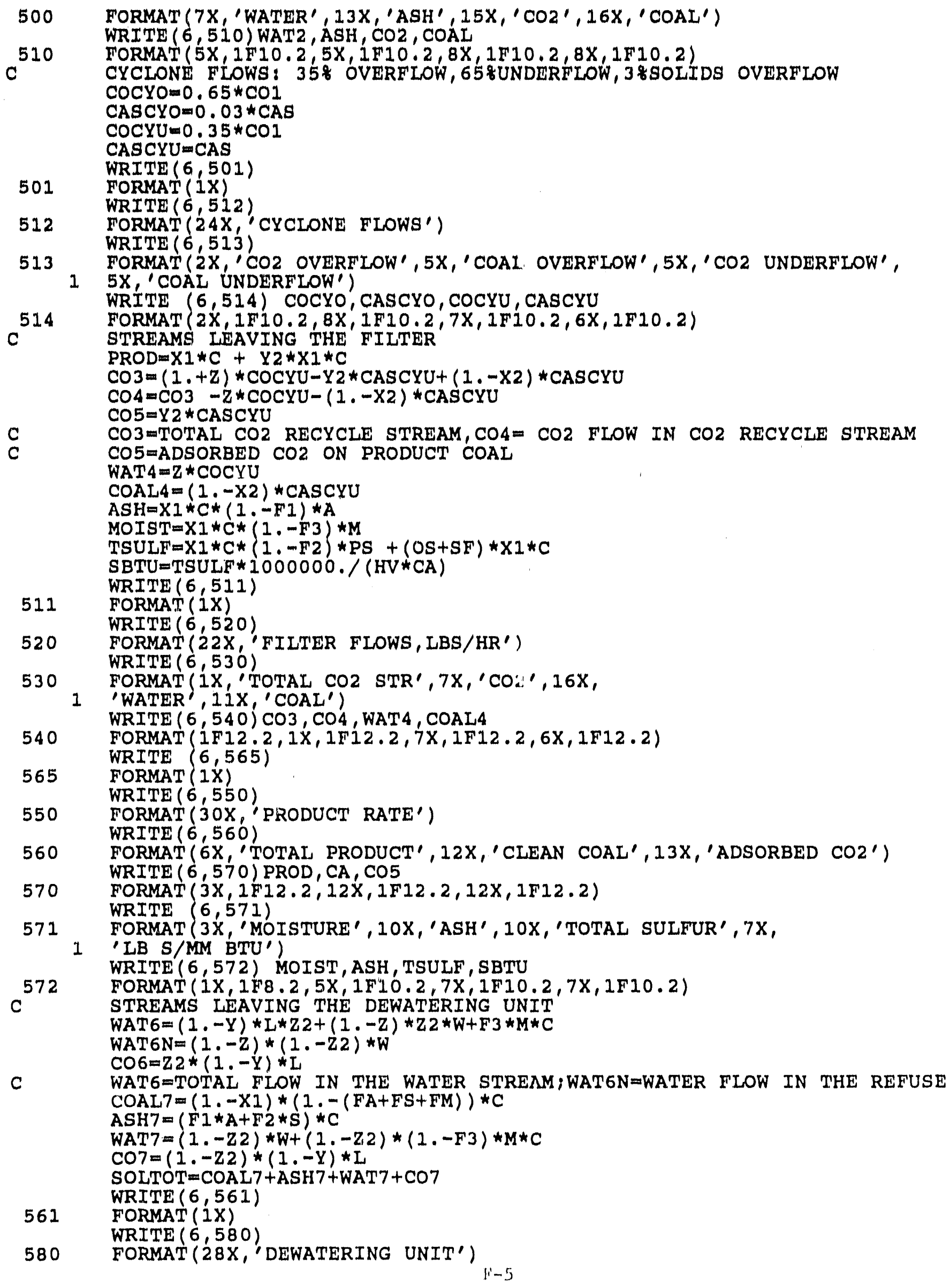




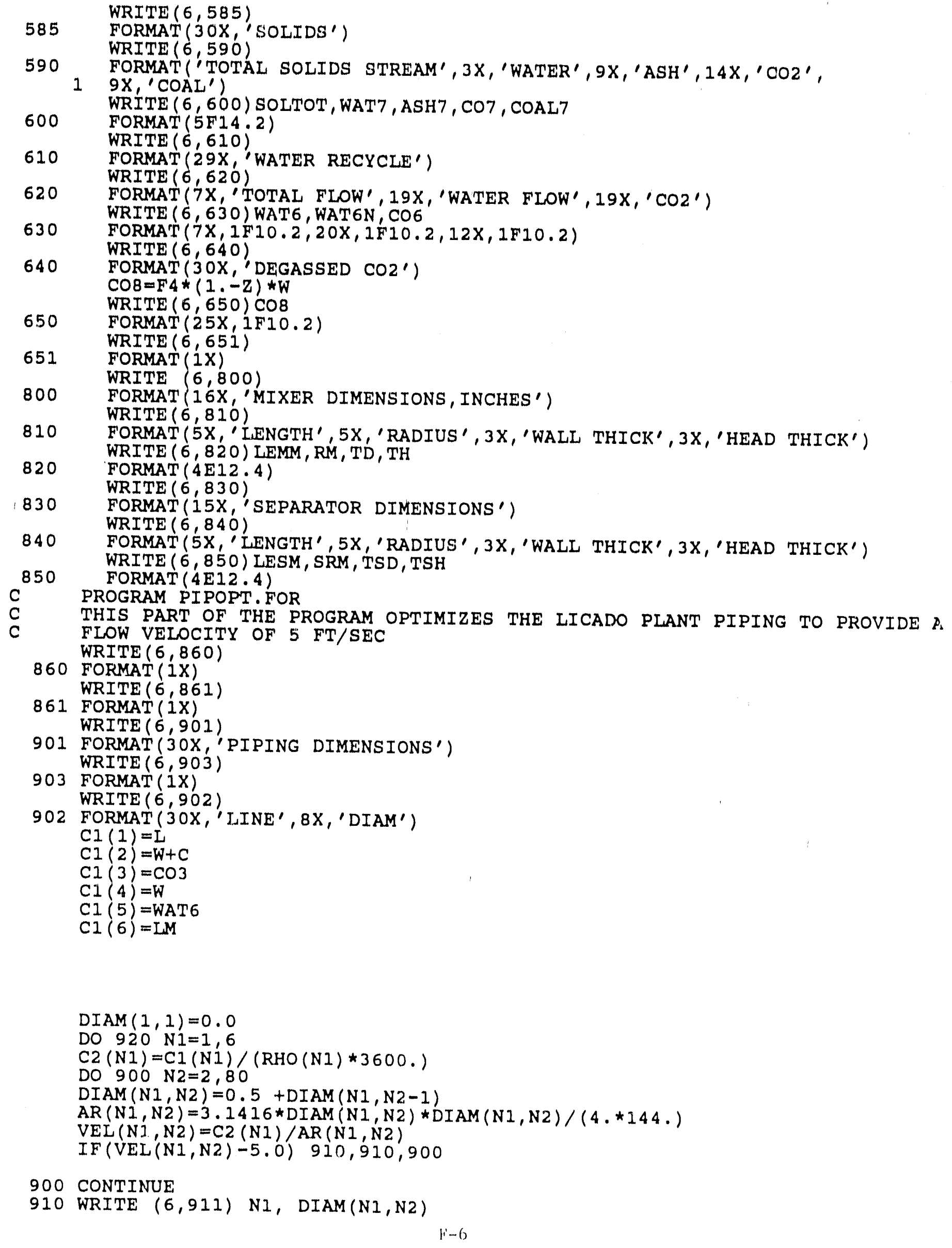


911 FORMAT (30X, 1I2, 4X, 1F10.2)

920 CONTINUE

WRITE $(6,931)$

931 FORMAT $(2 X)$

WRITE $(6,932)$

932 FORMAT ( $20 \mathrm{X}$, 'LINE 1=CO2 FROM CYCLONE TO MIXER')

WRITE $(6,933)$

933 FORMAT ( 2 OX, 'LINE 2=FEED FROM SLURRY TANK TO MIXER')

WRITE $(6,934)$

934 FORMAT ( 20 OX, 'LINE $3=C 02 / C O A L$ FROM SEPARATOR TO CYCLONE') WRITE $(6,935)$

935 FORMAT (2OX,'LINE 4=WATER FROM RECYCLE TANK TO GRINDER') WRITE $(6,936)$

936 FORMAT (20X,'LINE 5=WATER FROM REFUSE LETDOWN TO RECYCLE TATJ') WRITE $(6,937)$

937 FORMAT (2OX,'LINE 6=CO2 MAKE-UP LINE')

$A C=A \star C$

$\mathrm{SC}=(\mathrm{PS}+\mathrm{OS}+\mathrm{SF}) * \mathrm{C}$

$\mathrm{CM}=\mathrm{M} * \mathrm{C}$

$\mathrm{SRF}=\mathrm{F} 2 * \mathrm{PS} * \mathrm{C}$

$\mathrm{CO} 9=\mathrm{CO} 5+\mathrm{CO} 8$

CORCY $=\mathrm{COCYO}+\mathrm{CO} 4$

$\mathrm{ASHR}=\mathrm{F} 1 \star A \star C$

C THIS SECTION WRITES A SEPARATE FILE, FLOWST.DAT, FOR TRANSFER OF

C THE DATA TO THE CADD SYSTEM

WRITE $(7,731)$

731 FORMAT ( $24 \mathrm{X}$, 'LICADO PLANT SIMULATION')

WRITE $(7,732)$

732 FORMAT ( $23 \mathrm{X}$, 'UPPER FREEPORT COAL')

WRITE $(7,733) \mathrm{CA}$

733 FORMAT (22X,'PRODUCTION RATE, LB/HR=', 1F6.1)

710 WRITE $(7,710)$

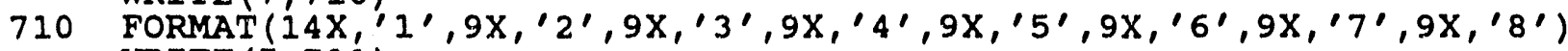
WRITE $(7,711)$

711 FORMAT(13X,'FEED', 4X,'GPNDR', 6X, 'SLURRY', 4X,'MIXER', 4X, 'CO2 RCY', $14 X$, 'SEP $\mathrm{PR}^{\prime}, 3 \mathrm{X},{ }^{\prime} \mathrm{SEP} \mathrm{RF}^{\prime}, 5 \mathrm{X},{ }^{\prime} \mathrm{CYL}$ OV')

WRITE $(7,712) \mathrm{C}, \mathrm{C}, \mathrm{C}, \mathrm{C}$

712 FORMAT('RAW COAL', E10.4,E10.4,E10.4,E10.4)

WRITE $(7,713)$ CA, COAL, CASCYO

713 FORMAT('CIN COAL', 50X, 3E10.4)

WRITE $(7,714) C M$, WR, W , W, WAT1, WAT2

714 FORMAT('WATER', 3X, 2E10.4,E10.4,E10.4,E10.4, 10X, 1E10.4)

WRITE $(7,715) \mathrm{L}, \mathrm{L}, \mathrm{CO} 1, \mathrm{CO} 2, \mathrm{COCYO}$

715 FORMAT('CO2-Iiq', 30X, 1E10.4,1E10.4,1E10.4,2E10.4)

WRITE $(7,716)$ CO5

716 FORMAT('CO2-gas ', 50X, 1E10.4)

WRITE $(7,717)$ AC, AC, AC, AC, ASH, ASHR

717 FORMAT('ASH', 5X,4E10.4,10X,2E10.4)

WRITE $(7,718)$ SC, SC, SC, SC, TSULF, SRF

718 FORMAT('SULFUR', 2X, 4E10.4,10X,1E10.4,2E10.4)

WRITE $(7,719)$

719 FORMAT (1X)

WRITE $(7,720)$

720 FORMAT (IX)

WRITE $(7,721)$

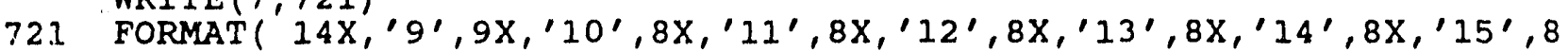
$\left.1 \mathrm{X},{ }^{\prime} 16^{\prime}\right)$

WRITE $(7,722)$

722 FORMAT( 1 OX, 'PRODUCT', 3X, 'FLTR LIQ', 2X, 'REFUSE GAS', 1X, 'PROD GAS', $12 \mathrm{X}$, 'COMPRESS', $3 \mathrm{X}$, 'REFUSE', $3 \mathrm{X}$, 'RECYL WTR', $2 \mathrm{X}$, 'MK UP WTR')

WRITE $(7,723)$

723 FORMAT ('RAW COAL')

WRITE $(7,724)$ CA, COAL4, COAL7

724 FORMAT ('CLN COAL', 2EI0.4,30X,E10.4)

WRITE $(7,725)$ MOIST, WAT 4 , WAT $6 N$, WR, WR' 
725 FORMAT('WATER', 3X, 2E10.4, 30X, 3E10.4)

WRITE $(7,726) \mathrm{CO} 4, \mathrm{CO9}, \mathrm{CO} 6$

726 FORMAT ('CO2-11q', 11X, 1E10.4,20X, 1E10.4, 10X, 1E10.4)

727 WRITE $(7,727) \mathrm{CO}, \mathrm{CO}, \mathrm{CO} 5, \mathrm{CO} 7$

727 FORMAT ('CO2-gas' , 1X, 1E10.4, 10X, 2E10.4, 10X, 1E10.4)

728 FORMAT ('ASH', 5X, 1E10.4,40X, 1E10.4)

WRITE $(7,729)$ TSULF, SRF

729 FORMAT('SULFUR', 2X, 1E10.4,40X, 1E10.4)

CLOSE (UNIT=7)

CLOSE (UNIT $=6$ )

CLOSE (UNIT $=5$ )

STOP

END 


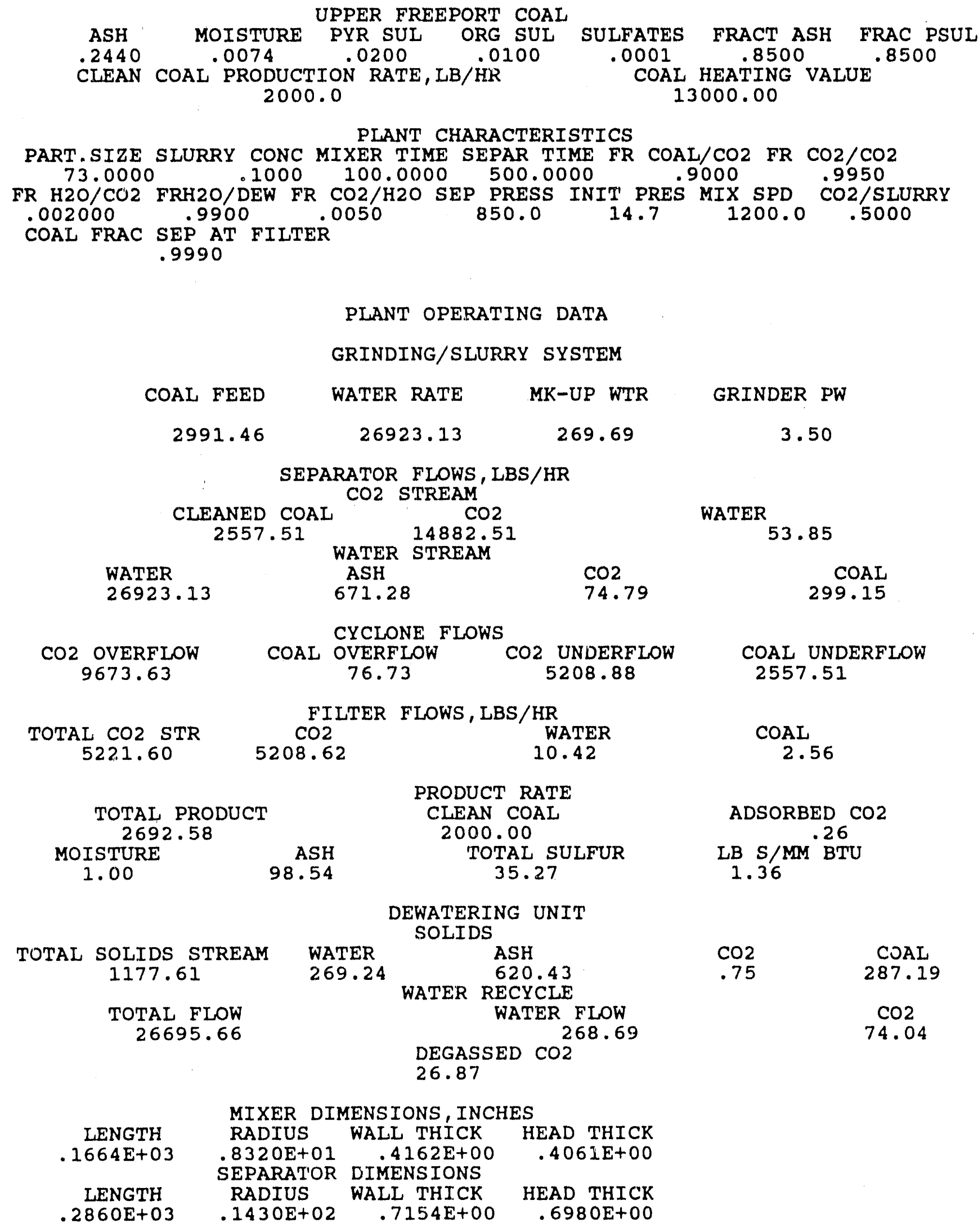

PIPING DIMENSIONS 


$\begin{array}{cr}\text { LINE } & \text { DIAM } \\ 1 & 2.00 \\ 2 & 2.50 \\ 3 & 1.50 \\ 4 & 2.50 \\ 5 & 2.50 \\ 6 & .50\end{array}$

LINE $1=\mathrm{CO} 2$ FROM CYCLONE TO MIXER LINE 2=FEED FROM SLURRY TANK TO MIXER

LINE $3=C 02 / C O A L$ FROM SEPARATOR TO CYCLONE

LINE 4=WATER FROM RECYCLE TANK TO GRINDER

LINE 5=WATER FROM REFUSE LETDOWN TO RECYCLE TANK

LINE 6=CO2 MAKE-UP IINE 
APPENDIX G

G-1 
LICADO Commercial Plant, 200 Ton/Hour Budgetary Cost Estimate, Fixed Capital

\section{DIRECT COSTS}

\section{Item/Components}

2. Filters (Pitt Auger)

3. Water Pump (Make-up) Piston

4. Water Pump (Recycle)

5. Slurry Feed Pump (Coal/Water)

6. $\mathrm{CO}_{2}$ Circulating Pump (Main)

7. $\mathrm{CO}_{2}$ Filtrate Pump (Not Shown)

8. Lock Hopper (Raw Coal)

9. Slurry Tanks (Coal/Water)

11. Separator

12. Refuse Depressurizer

13. Recycle Water Vessel

14. Product Coal Vessel

15. Pressurizer

16. $\mathrm{CO}_{2}$ Accumulator

17. $\mathrm{CO}_{2}$ Recycle Compressor

18. Cyclones

19. Coolers

20. Filters (Gaseous)

21. Water Storage (Atmosphere)

(A) Total Components

(B) Installation (factor $=0.39 \mathrm{~A}$ )

(C) Instrumentation $\quad(0.13 \mathrm{~A})$

(D) Piping, Installed $(0.31 \mathrm{~A})$

(E) Electrical System $(0.10 \mathrm{~A})$

(F) Site Preparation (0.10A)

(G) Gen. Serv. \& Utilities (Assumed)
1. Raw Coal Preparation (Turn Key)

10. Hydraulic Mixer

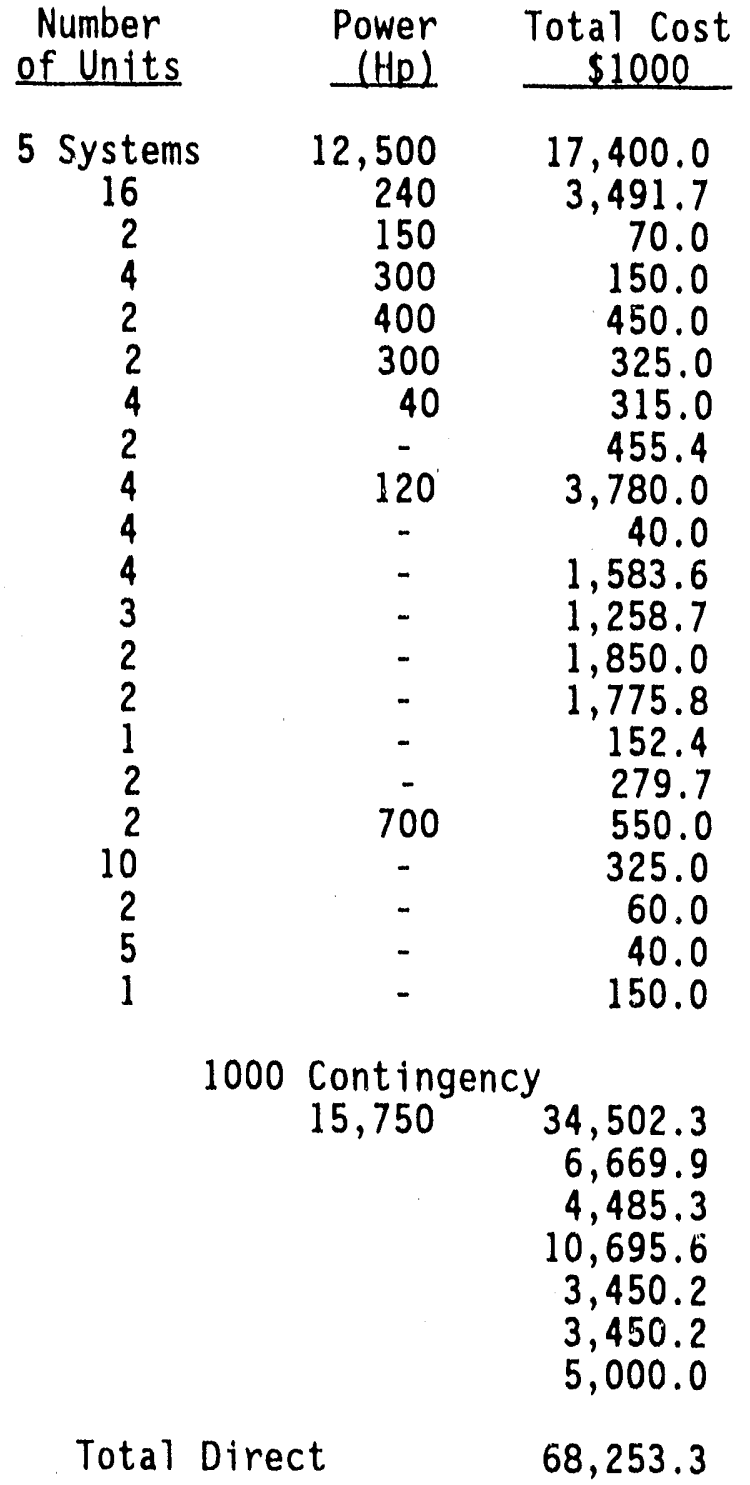

\section{INDIRECT COSTS}

(H) Engineering \& Supervision (0.20A)

(J) Construction $(0.45 \mathrm{~A})$ (Item 1 omitted, Turn Key)

(K) Contractor's Fee (0.09A)

(L) Contingency (0.25A) 
Agglomeration Commercial Plant, 50 Ton/Hour Budgetary Cost Estimate, Fixed Capital

\section{Item/Components}

1. Cyclones

2. Siurry Feed Tanks

3. Mixer

4. Filter, Moving Screen

5. Clean Coal Receiver

6. Clean Coal Depressurizer

7. $\mathrm{CO}_{2}$ Recycle Accumulator

8. $\mathrm{CO}_{2}$ Recycle Compressor

9. Pressurizer

10. Water Pump, Concentration Adjm't

11. Slurry Pump, Coal/Water

12. $\mathrm{CO}_{2}$ Circulating Pump

13. Gas Filters

14. Heat Exchanger

(A) Total Components

(B) Installation (factor $=0.39 \mathrm{~A}$ )

(C) Instrumentation

(D) Piping, Installed

(E) Electrical System

(F) Site Preparation

(G) Gen. Serv. \& Utilities (0.25A)

\section{DIRECT COSTS}

Number Power Total Cost of Units (HD) $\$ 1000$

4-10's

2

100

$1 \quad 75 \quad 120$

$\begin{array}{lll}2 & 10 & 664\end{array}$

$2 \quad-1445$

$1 \quad-\quad 223$

$1 \quad-\quad 70$

$1 \quad 800 \quad 397$

$1 \quad-77$

$1 \quad 55011$

$\begin{array}{rrr}1 & 150 & 173 \\ 1 & 25 & 40\end{array}$

$2 \quad-\quad 10$

$1 \quad-\quad 15$

235 Contingency

$1400 \quad 2,621$

1,022

524

813

262

262

655

Total Direct $\quad 6,159$

\section{INDIRECT COSTS}

(H) Engineering \& Supervision (0.40A)

(J) Construction $(0.45 \mathrm{~A})$

(K) Contractor's Fee (0.09A)

(L) Contingency $(0.40 \mathrm{~A})$

$\begin{array}{lr} & 1,048 \\ & 1,179 \\ & 236 \\ & 1,048 \\ & \\ \text { Total Indirect } & 3,511 \\ \text { Total Fixed Capital } \quad 9,670\end{array}$


APPENDIX G-2
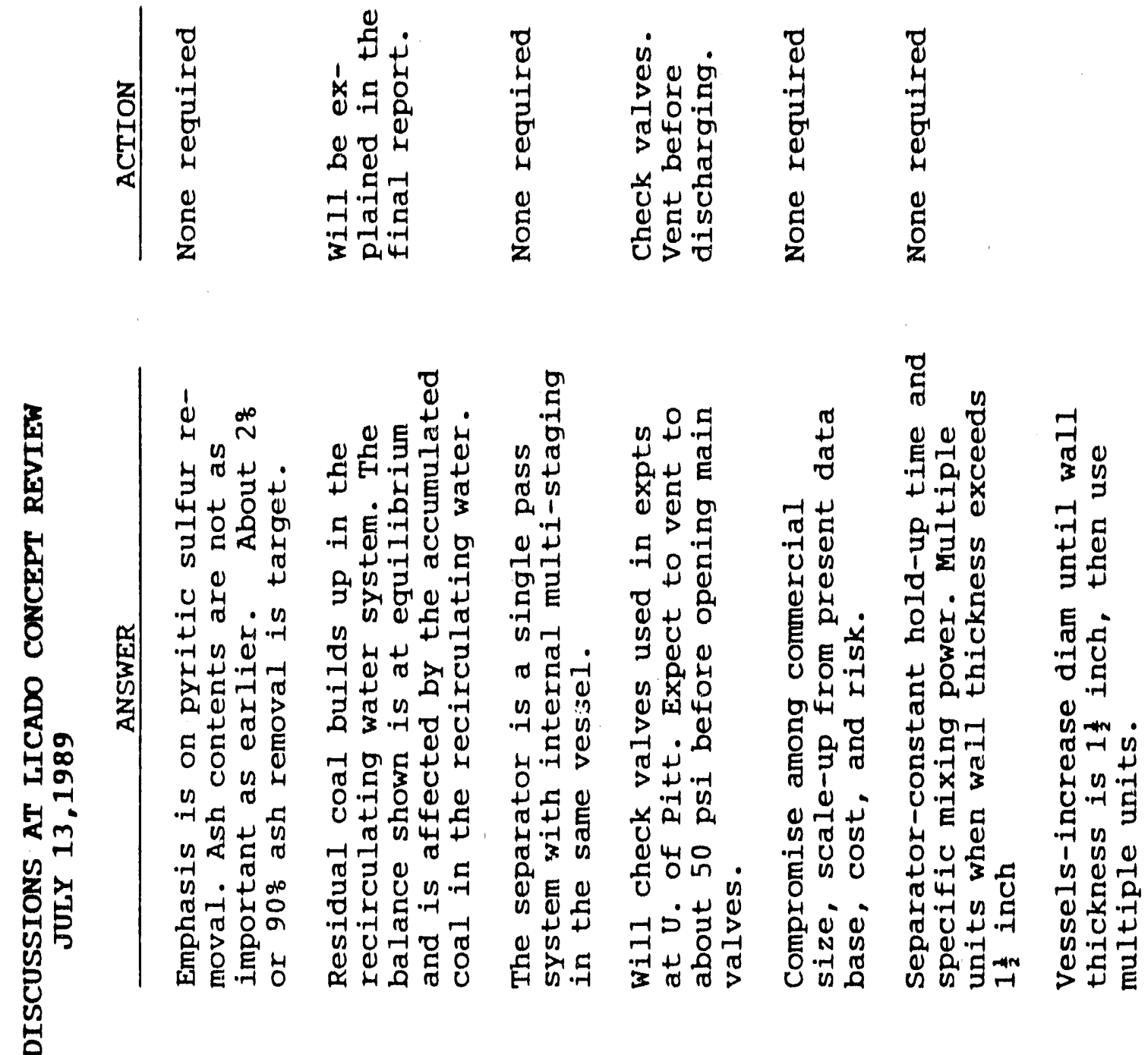

皆
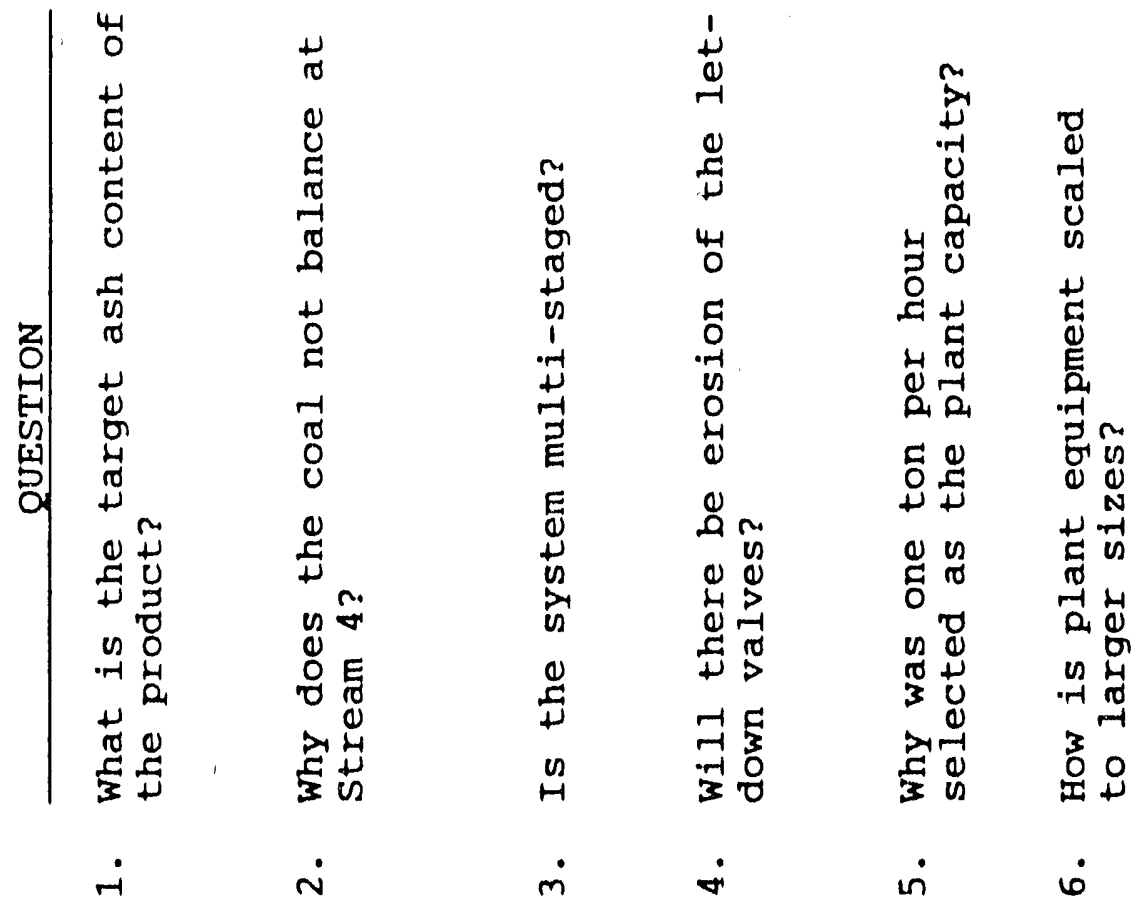


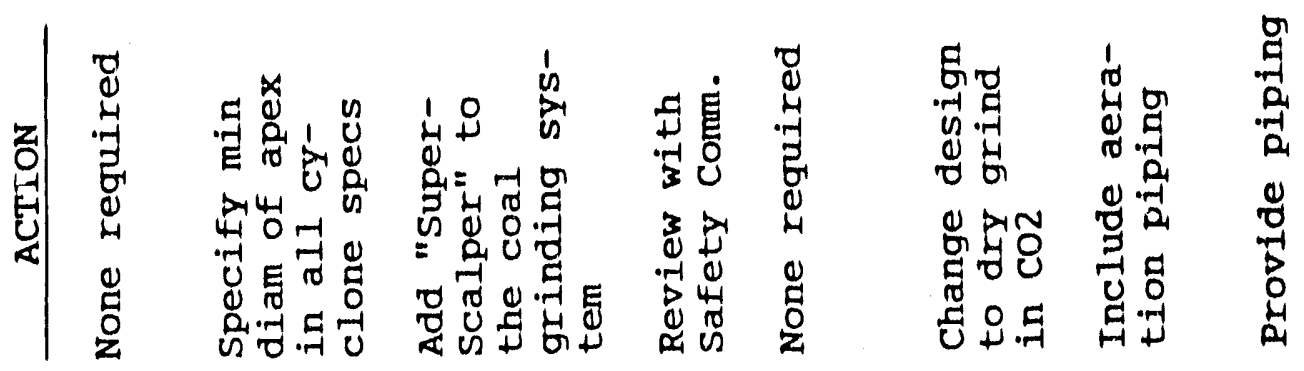
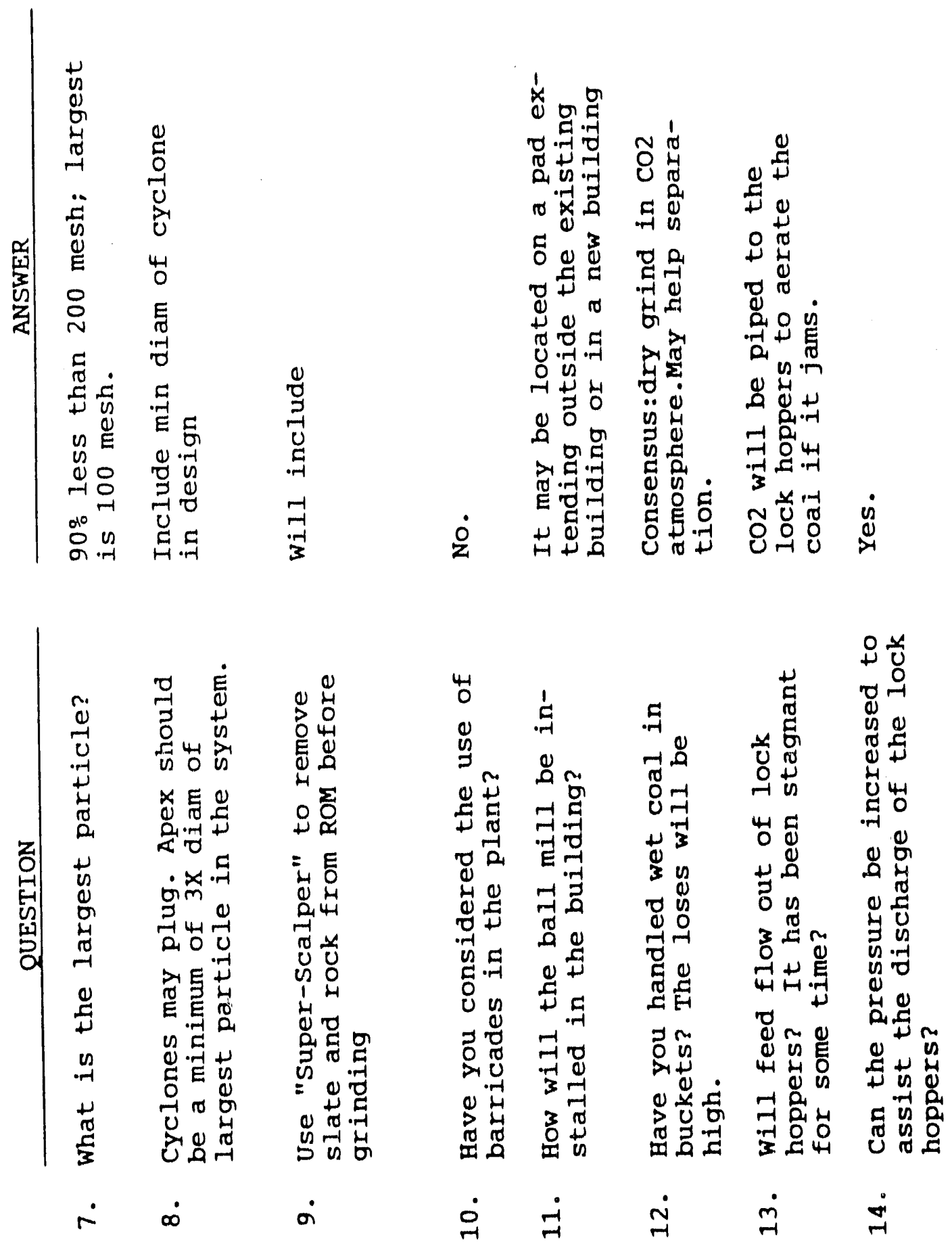
APPENDIX G-2
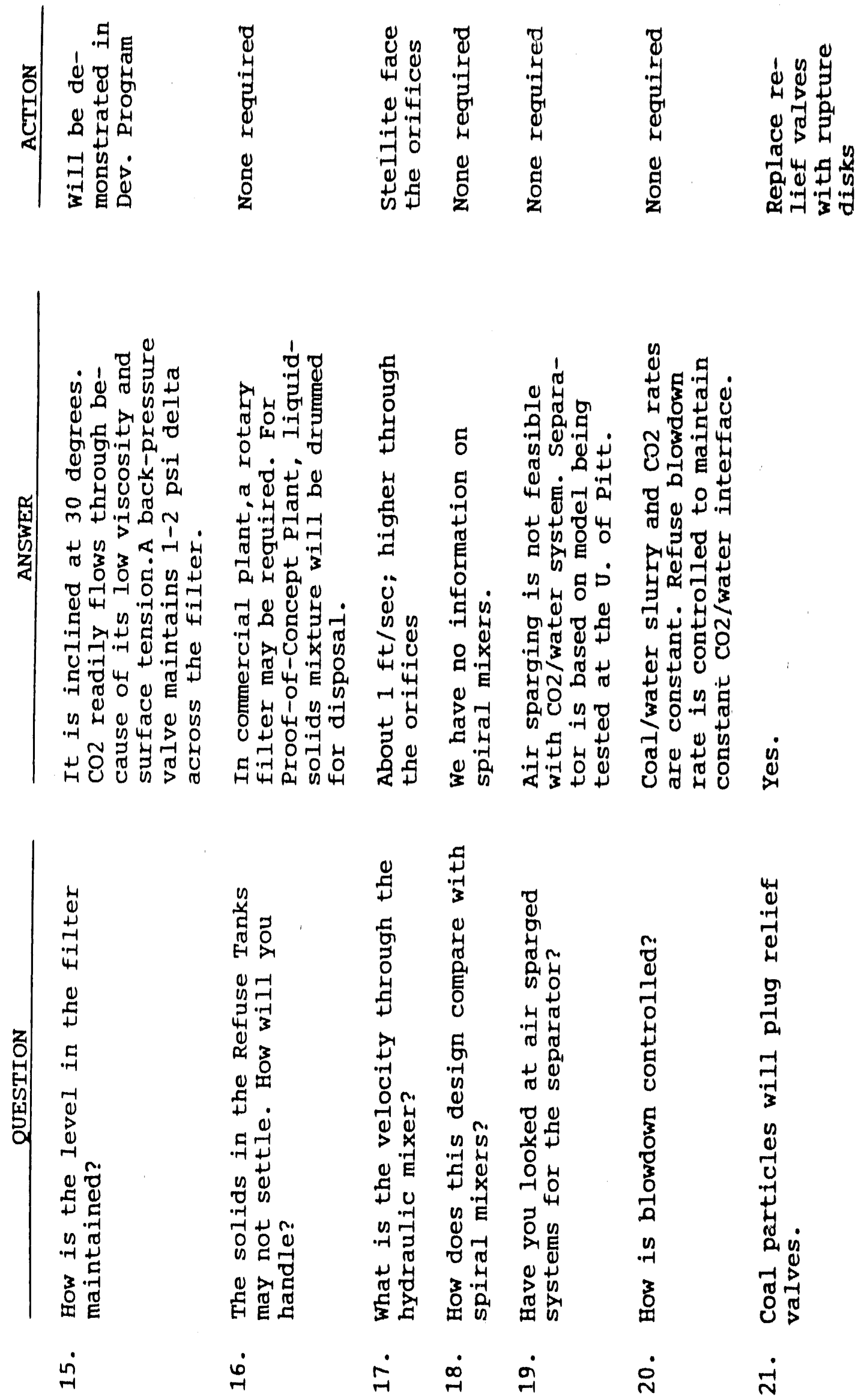

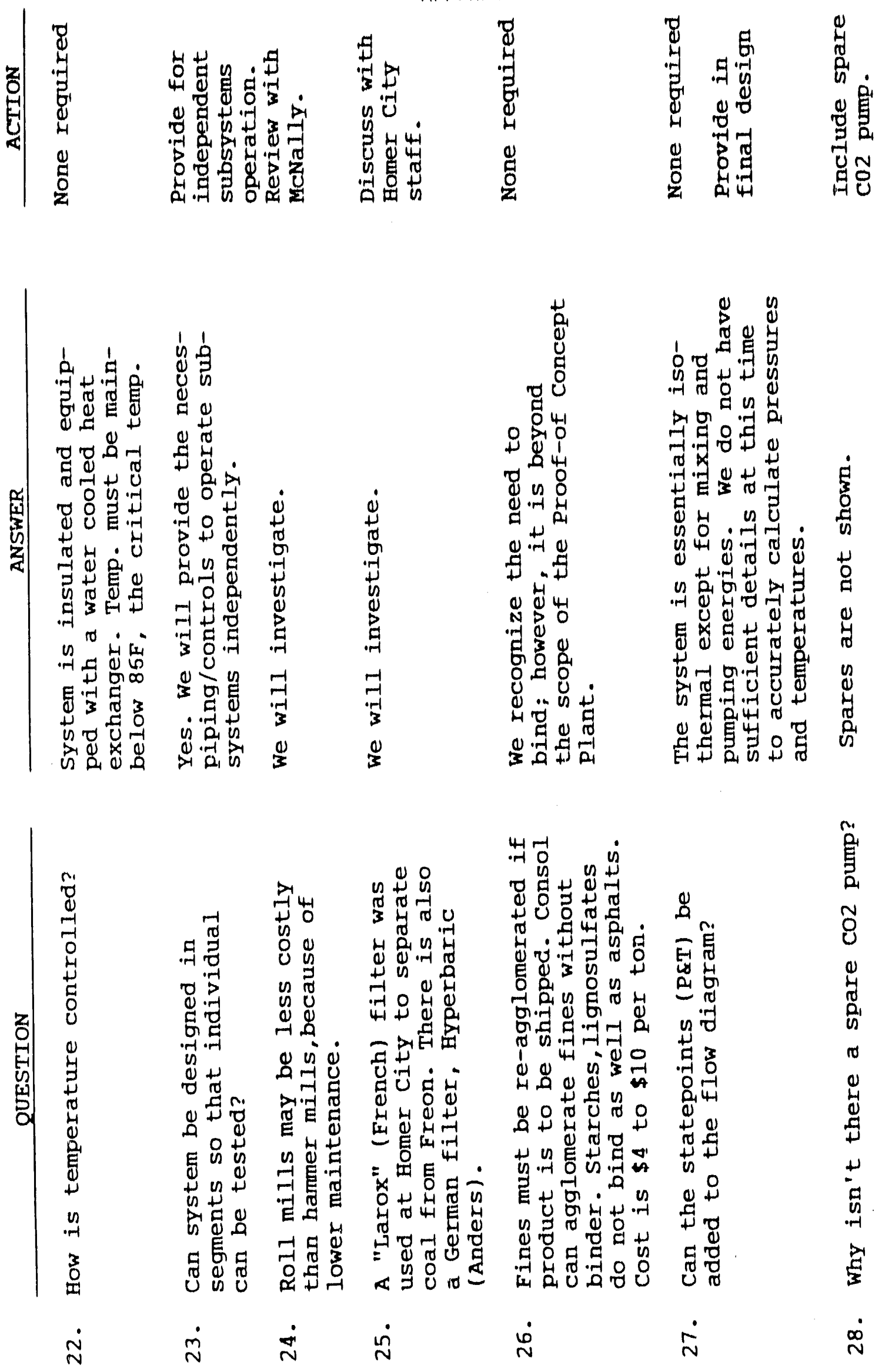


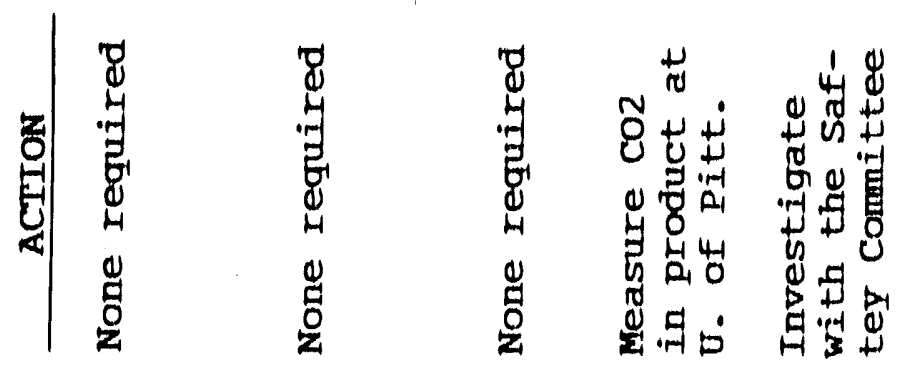

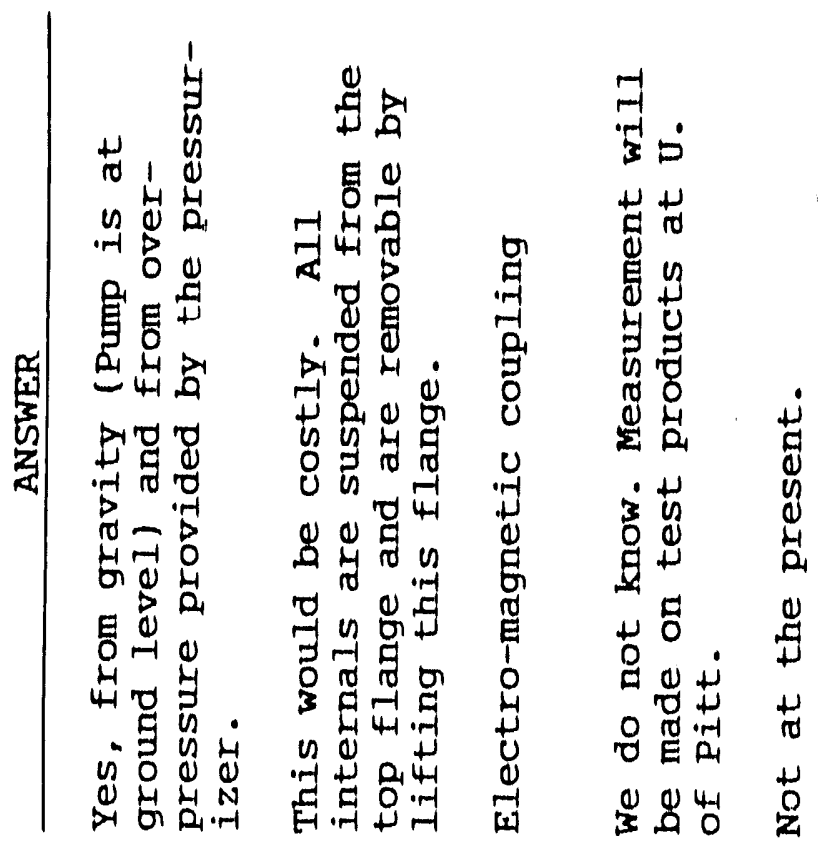

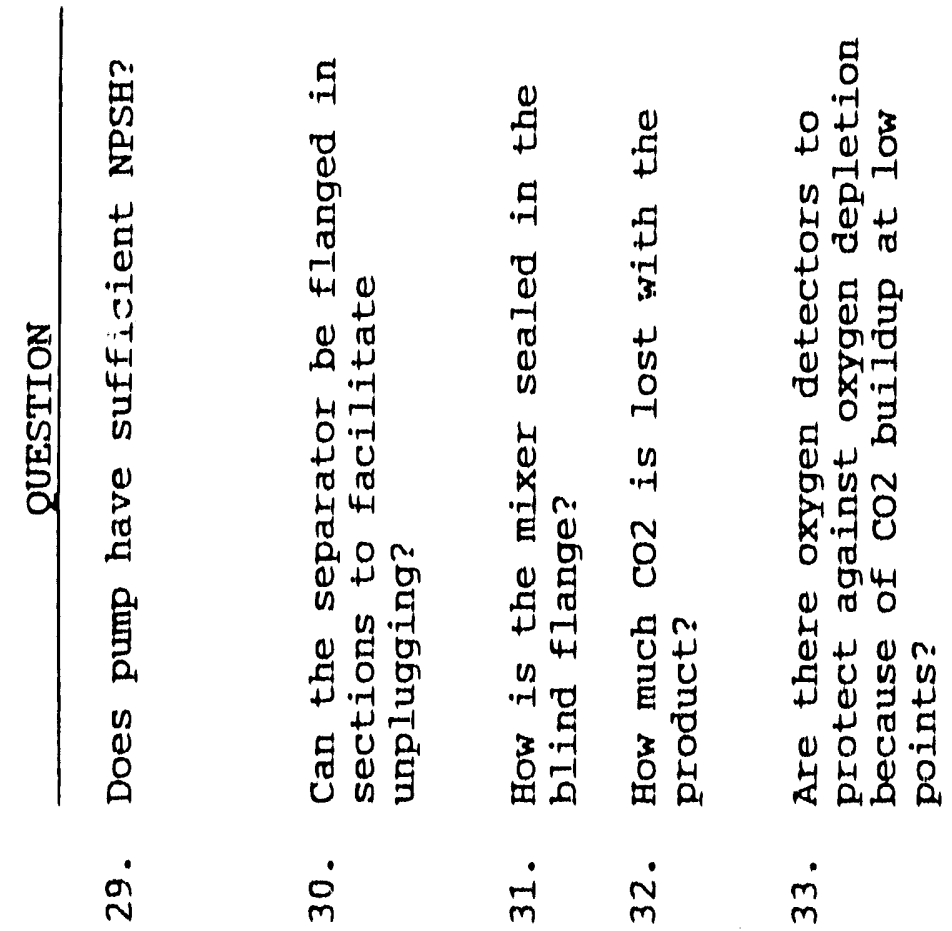

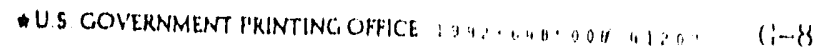



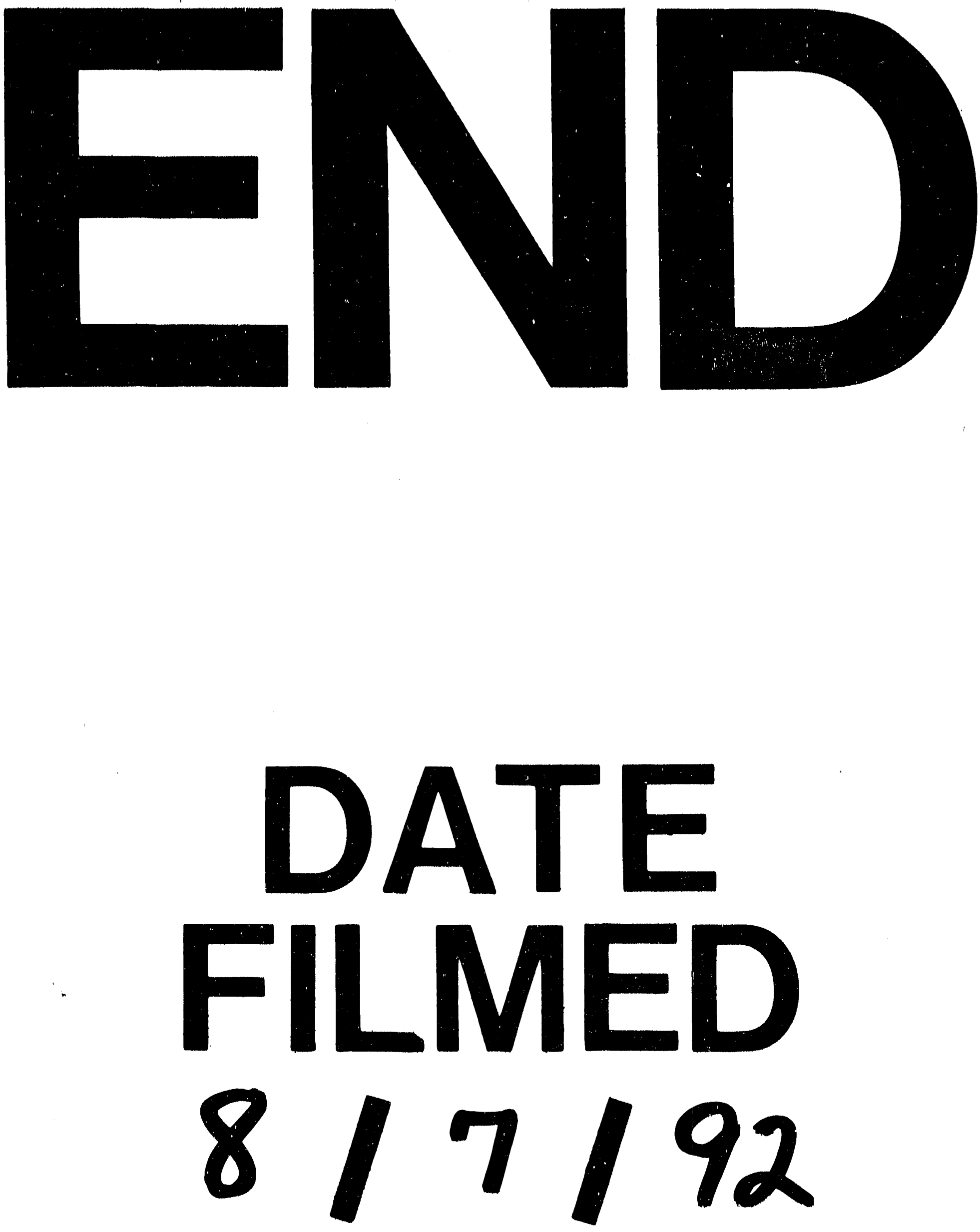
